UNIVERSIDADE DE SÃO PAULO

Escola de Enfermagem de Ribeirão Preto

\title{
O pensamento crítico social de Paulo Freire sobre humanização e o contexto da formação do enfermeiro, do médico e do odontólogo
}

Rodrigo Otávio Moretti-Pires 
RODRIGO OTÁVIO MORETTI PIRES

\section{O pensamento crítico social de Paulo Freire sobre humanização e o contexto da formação do enfermeiro, do médico e do odontólogo}

Tese apresentada ao Programa de Pós-Graduação em Enfermagem Psiquiátrica da Escola de Enfermagem de Ribeirão Preto para obtenção do título de Doutor em Enfermagem.

Linha de Pesquisa: Educação e formação de recursos humanos em saúde.

Orientadora: Profa. Dra. Sônia Maria Villela Bueno 
AUTORIZO A REPRODUÇÃO E DIVULGAÇÃO TOTAL OU PARCIAL DESTE TRABALHO, OR QUALQUER MEIO CONVENCIONAL OU ELETRÔNICO, PARA FINS DE ESTUDO E PESQUISA, DESDE QUE CITADA A FONTE.

Ficha catalográfica

Moretti-Pires, Rodrigo Otávio

O pensamento crítico social de Paulo Freire sobre humanização e o contexto da formação do enfermeiro, do médico e do odontólogo/Rodrigo Otávio MorettiPires. --Ribeirão Preto, 2008.

$342 \mathrm{fls}$.: il.; $30 \mathrm{~cm}$.

Tese (Doutorado) Escola de Enfermagem de Ribeirão Preto/USP. Programa de Pós-Graduação em Enfermagem Psiquiátrica.

Orientadora: Sônia Maria Villela Bueno

1.Ensino Superior. 2. Enfermagem. 3. Medicina. 4. Odontologia. 5.Paulo Freire. 


\section{FOLHA DE APROVAÇÃO}

Rodrigo Otávio Moretti-Pires

O pensamento crítico social de Paulo Freire sobre humanização e o contexto da formação do enfermeiro, do médico e do odontólogo

Tese apresentada à Escola de Enfermagem de Ribeirão Preto da Universidade de São Paulo, para obtenção do título de Doutor.

Área de Concetração: Enfermagem Psiquiátrica

Aprovado em: /2008

\section{BANCA EXAMINADORA}

Prof $^{\mathrm{a}} \mathrm{Dr}^{\mathrm{a}}$ Sônia Maria Villela Bueno (orientadora) Instituição:

Assinatura:

$\operatorname{Prof}^{a} \operatorname{Dr}^{\mathrm{a}}$

Instituição:

Assinatura:

$\operatorname{Prof}^{a} \operatorname{Dr}^{a}$

Instituição:

Assinatura:

$\operatorname{Prof}^{a} D^{a}$ Instituição:

Assinatura:

$\operatorname{Prof}^{a} \operatorname{Dr}^{\mathrm{a}}$

Instituição:

Assinatura: 


\section{dedicatória}

Esta obra é para Você, meu eterno Amor, que rege meus caminhos, dentro da Eternidade. 


\title{
agradecimentos
}

\author{
À Universidade de São Paulo, à Escola de Enfermagem de Ribeirão \\ Preto e ao Programa de Pós Graduação em Enfermagem \\ Psiquiátrica, por garantirem a estrutura de excelência em \\ capacitação de Doutorado que cursei.
}

À minha orientadora, Prof ${ }^{\mathrm{a}} \operatorname{Dr}^{\mathrm{a}}$ Sônia Maria Villela Bueno, que me recebeu com os braços abertos e sorriso no lábios, abrindo portas que jamais pensei que me seriam possíveis. Em particular pelo exemplo, que levarei durante toda a minha carreira como um ideal a

ser alcançado, dada sua postura viva, atuante e coerente com os

À Universidade Federal do Amazonas, e ao Instituto de Saúde e

princípios de Freire.

Biotecnologia, minha casa, em que não apenas tenho meu sustento, mas exerço minha docência e crio minha vida.

Ao $\operatorname{Prof}^{\circ} \operatorname{Dr}^{\circ}$ Hidembergue Ordogoizth da Frota, Magnífico Reitor da UFAM

por incentivar e permitir que, mesmo sendo novo na carreira, pudesse terminar meu Doutorado.

Ao $\operatorname{Prof}^{\circ} \operatorname{Dr}^{\circ}$ Altigran Soares da Silva,

Pela amizade, incentivo e conselhos, sempre tão precisos e preciosos.

Ao Prof ${ }^{\circ}$ Paulo Jacob,

Pela convivência e por permitir que, mesmo em meio a nossas

Às Prof ${ }^{\text {as }}$ Dr $^{\text {as }}$ Ana Cyra e Rosana Parente, atribuladas funções, eu conseguisse construir a presente tese

"dupla dinâmica" que desde o início me receberam na UFAM com

carinho, amizade e coleguismo.

Ao Prof ${ }^{\circ}$ Tiótrefis,

Colega valoroso, por sempre estar ao meu lado nas lutas cotidianas e por todas as vezes que, prontamente, me socorreu quando se fez necessário que eu deixasse parte de minhas atividades de ensino, pesquisa ou extensão, no intuito de dar mais um passo na

À Prof ${ }^{\mathrm{a}} \mathrm{Dr}^{\mathrm{a}}$ Margarita e Prof $^{\mathrm{a}} \mathrm{Dr}^{\mathrm{a}}$ Adriana Kátia

consecussão da presente.

Pelas inestimáveis considerações quanto ao Projeto, durante o

Exame de Qualificação

Às Sras. Adriana e Kethllen, Cujo auxílio e orientação durante estes dois anos de Doutorado foram

À Prof ${ }^{\mathrm{a}} \mathrm{MSc}$ Sandra Greice e ao $\operatorname{Prof}^{\circ} \operatorname{Dr}^{\circ}$ Edson

inestimáveis.

Amigos presentes, mesmo na distância entre Coari e Manaus.

Ao Centro de Pesquisa "Leônidas e Maria Deane" - Fiocruz Na figura da Prof $^{a}$ Dr $^{\text {a }}$ Luiza Garnello

Cuja autorização para que eu cursasse disciplinas foi um auxílio inestimável na construção do presente trabalho. 
Ao discente Thiago de Oliveira Pires,

Aluno, amigo, cujo auxiliou em diversas fases da presente pesquisa foi fundamental

Ao $\operatorname{Prof}^{\circ} \operatorname{Dr}^{\circ}$ Fernando Brandão dos Santos, irmão, amigo e inspiração nesta vida tão complexa.

Aos amigos Camila, Gil, Rosana e Marcos, pela amizade e a família que somos sempre.

Aos meus queridos Kenne, Jath, Rômulo, Roney e Regilson, companheiros no serviço educacional, que fazem o trabalho se tornar leve e divertido.

Aos meus amigos e orientados Kaline, Levi e Bruno,

Amigos e alunos com os quais desfruto da prazerosa convivência diária

À minha amiga Clarissa, por tudo, Clá!

Aos meus queridos primos Bia, Beta, Érika, Jana e Joaquim, que mais do que primos, tornaram-se meus irmãos em Manaus, sem os quais eu jamais conseguiria me sentir em casa, tão longe das origens. $E$ aos 'anexos' Eduardo, Jão, André e Laura, família no real sentido.

À minha Raquel e sobrinha Lu, por viverem e tornarem a vida mais interessante para todos os que as rodeiam.

Aos meus pais, Áurea e Laudelino, por permitirem que não apenas eu viesse a vida, mas, que me permitiram ter uma visão inconformada.

À Lis e Fran, família no mundo, onde estivermos.

À minha Rosa, que mais que esposa, construiu comigo.

À Vida e ao Deus de meu coração e em minha compreensão, que traça com a precisão de Compasso e Esquadro, as maravilhas que se realizam no viver. 


\section{epígrafe}

MUTATIS MUTANDI

A dor de perder tudo o que sempre prezou, apenas para seguir?

Pois é... Ai está a grande questão: seguir o que? Ou, melhor pesando: perder o que? As coisas que mais nos apegamos serão realmente verdadeiras? Frente às grandes verdades, e a humanidade... o que é real? Qual a chave para se ser feliz? O que fazer quando se enxerga que só temos a nós mesmos e a nossa honra? Não a honra do mundo. Não a das pessoas. Mas a nossa. Simplesmente por nós. Honrar-se pela singularidade que te faz você e pela singularidade que me faz eu. Brindemos a isso, meu caro! Sou e és! A nada e a ninguém devemos, apenas à nossa Consciência. E mais: se conscientemente desejarmos desvendar os

véus que o Destino coloca para proteger o Segredo Santo e Incomunicável do que nossa vida realmente é, tudo o que sempre quisemos nos será dado... e tirado de nós, até o solo sob nossos pés. Até mesmo nossos pés. Tudo te será dado e... em um piscar de olhos arrancado até tua carne de teus ossos... Pois que assim a Vida determina: não terás outros Senhores senão o próprio viver.

Homem, ser sociável e indissociável da unidade chamada

humanidade. O Um. O Uno. O Único. Servo e Servidor de Si mesmo. O Total. E então... depois de tudo arrasado pelos doces e implacáveis braços de Shiva, Bramah ${ }^{1}$ dará exatamente o que se quer. Por que saber exatamente o que queremos é tão difícil quando viver. Exatamente. E a perspicácia será testada, pois enxergar o que realmente se quer na vida é tarefa humana. Digna de fazer de Hércules ${ }^{2}$ membro do Olimpo ${ }^{3}$, ele que também era humano. Mas creia, amigo, inimigo, seja você quem for que estiver lendo estas palavras: ai encontra-se o real perigo. Se o desafio maior é se saber o que se realmente quer... a vida estraçalhada... e teus caprichos e vontades desarmados... o maior perigo é ter o que se quer. $E$ tendo, fazer o que deve ser feito, por que a Fortuna não brinca. Nunca. E nunca brinque com ela, pois que ela "Semper Crecis aut decrecis, vita detestabilis; nunc obdurant et tuncurat,

Iudo mentis accien; Egestatem... Potestatem... dissolvit ut glaciem $^{4 \prime}$. Eis que estou aqui. Em Coari. Professor. E ser humano.

Ser. Humano. Humano sendo ser, sem ser e sendo, fazendo, querendo, vivendo. Ensinar... com ou aos educandos? Seres... humanos... tão humanos e tão seres como eu... Ao passado... que morra e seja enterrado, esquecido nas areias do tempo, e como pó, soprado pelo vento que o leve aos quintos dos infernos mais profundos, onde Hades ${ }^{5}$ vigia aqueles que não conseguiram se mostrar heróis, não conseguiram serem humanos e não permanecerão, por isso, junto a Odin ${ }^{6}$, no Aesyr ${ }^{7}$... Ao presente, que prospere e mostre a que veio. Ao futuro... que seja. Simplesmente. Seja. Que me leve apenas a dignamente sentar-me com aqueles que foram, que não existem mais, e vivem para sempre, novamente.

Rodrigo Otávio Moretti-Pires Coari (AM), 10.08.2006

Mitologia Hindu: Shiva e Bramah - deus da destruição e deus da criação. 
Esta tese está de acordo com as seguintes normas, em vigor no momento da publicação:

Referências: Internacional Committee of Medical Journals Editors (Vancouver)

Apresentação de autores: Sistema Numérico, conforme

Universidade de São Paulo. Sistema Integrado de Bibliotecas. Diretrizes para apresentação de dissertação e teses da USP: documentos eletrônico e impresso / Furano VMB (coord.) et al.São Paulo: SIBi-USP, 2004, 110p. 


\section{RESUMO}

MORETTI-PIRES, RO. O pensamento crítico social de Paulo Freire sobre humanização e o contexto da formação do enfermeiro, do médico e do odontólogo. 2008. 342 fls. Tese (Doutorado) - Escola de Enfermagem de Ribeirão Preto, Universidade de São Paulo, 2008.

A partir do processo de implementação do Sistema Único de Saúde, diversos desafios foram emergindo de um contexto histórico, pautado na exclusão. Diversas estratégias foram utilizadas no sentido de superar os problemas e, entre estas, se destaca o Programa de Saúde da Família, cujos princípios se norteiam pela proximidade do usuário, centralidade na família, trabalho multiprofissional. No entanto, a questão da falta de formação e preparo dos profissionais se apresenta principalmente que se refere ao tratamento humanizado. Neste sentido, o estudo foi construído sob o universo conceitual originado dos trabalhos de Paulo Freire, em particular aos conceitos referentes e articulados a temática da humanização. O presente trabalho objetivou investigar em que medida o modelo pedagógico universitário tem influências na formação do enfermeiro, do médico e do odontólogo com relação à humanização, que no marco teórico freireano significa o bem tratar do paciente, mas também a inserção do profissional como ator social transformador. Para tanto, foram investigados os cursos de Enfermagem, Medicina e Odontologia de uma Universidade Federal da Região Norte do Brasil, pautando-se na perspectiva qualitativa. Como técnicas, foram realizados um encontro de grupo focal para cada curso, com seis acadêmicos do último período. Na etapa seguinte, realizou-se entrevista semiestruturada e individual, com os acadêmicos que participaram dos Grupos focais. Utilizou-se, ainda, da análise documental das matrizes curriculares dos cursos. Os resultados indicam que o ensino em Enfermagem, em Medicina e em Odontologia apresenta talhe tradicional, narrativo e depositário, conforme Freire, direcionamento que implica na vivência desumanizadora do acadêmico durante o curso universitário e que, segundo o referencial teórico, se refletirá na postura futura dos educandos. Os resultados sugerem a premente necessidade de reorientação dos modelos pedagógicos dos cursos estudados, com vistas a formação de enfermeiros, médicos e odontólogos com prática pautada no pensamento histórico-político e crítico reflexivo.

Descritores: Ensino Superior, Enfermagem, Medicina, Odontologia, Pensamento Crítico. 


\begin{abstract}
MORETTI-PIRES, RO. The critical thinking of Paulo Freire about humanization and graduate context to nurse, physical and dentist. 2008. $342 \mathrm{fls}$. Thesis (Doctoral) - University of São Paolo at Ribeirao Preto School of Nursing, 2008.

From the process of implementation of the Single Health System, several challenges were emerging from a historical context, guided the exclusion. Several strategies were used to overcome the problems and, among these, are the highlights of the Family Health Program, whose principles are guiding the proximity of the user, centrality in the family, multidisciplinary work. However, the issue of lack of training and preparation of professionals presents mainly regard to the treatment humanized. Therefore, the study was built under the conceptual universe originated the work of Paulo Freire, in particular relating to the concepts articulated in the subject of humanization. This study aimed to investigate the extent to which the pedagogical model university has influence in the training of nurse, doctor and dentist with respect to the humanization, which in the theoretical framework freireano means and treat the patient, but also the inclusion of professional and social actor processor. For both, were investigated the courses of Nursing, Medicine and Dentistry of a Federal University of the north of Brazil, in the qualitative perspective. As techniques were performed a meeting of focus group for each course, with six of the last academic period. In the next stage, held up a semi-structured and individual, with the scholars who participated in focus groups. It was used, in addition, the analysis of the documentary matrices curricula of the courses. The results indicate that education in Nursing, Medicine and Dentistry presents cut traditional, narrative and depositary, as Freire, targeting implies that the experience during the course of the academic university, which, according to the theoretical reference, if reflect on the future posture of the students. The results suggest the urgent need for reorientation of the teaching models of the courses studied, with a view to training for nurses, doctors and dentists with guided practice in the historical-political thinking and critical reflection.
\end{abstract}

Keywords: Higher Education, Nursing, Medicine, Dentistry, Critical Thinking 


\section{RESUMEN}

MORETTI-PIRES, RO. El pensamiento crítico social del Paolo Freire sobre la humanicion e el contexto de la formacion del enfermero, del medico e del dentista. 2008. $342 \mathrm{fls}$. Tese (Doctorado) - Escuela de Enfermería de Ribeirão Preto, Universidad de São Paulo.

Desde el proceso de aplicación del Sistema Único de Salud, varios problemas se salen de un contexto histórico, guiado a la exclusión. Se utilizaron varias estrategias para superar los problemas y, entre estos, son los aspectos más destacados del Programa de Salud de la Familia, cuyos principios rectores son la proximidad del usuario, centralidad en la familia, trabajo multidisciplinario. Sin embargo, la cuestión de la falta de formación y preparación de los profesionales que se presenta principalmente respecto al trato humanizado. Por lo tanto, el estudio se construyó en el marco del universo conceptual se originó el trabajo de Paulo Freire, en particular los relativos a los conceptos expresados en el tema de la humanización. El objetivo del estudio fue investigar la medida en que el modelo pedagógico de la universidad tiene influencia en la formación de la enfermera, médico y dentista con respecto a la humanización, que en el marco teórico freireano medios y tratar al paciente, sino también la inclusión de los profesionales y sociales Actor procesador. Por tanto, se investigaron los cursos de Enfermería, Medicina y Odontología de la Universidad Federal de la zona norte de Brasil, pautando en la perspectiva cualitativa. Como técnicas se realizaron una reunión de grupo de enfoque para cada curso, con seis de los últimos periodo académico. En la próxima etapa, que tuvo lugar un semi-estructurada e individual, con los estudiosos que participaron en grupos de enfoque. Se utilizan, además, el análisis de los documentos matrices de los planes de estudio de los cursos. Los resultados indican que la educación en Enfermería, Medicina y Odontología presenta corte tradicional, la narrativa y el depositario, como Freire, la orientación implica que la experiencia deshumanizadora durante el curso académico de la universidad, que, según el teórico de referencia, en caso de reflexionar sobre el futuro postura De los estudiantes. Los resultados sugieren la urgente necesidad de reorientación de los modelos de enseñanza de los cursos estudiados, con miras a la formación de las enfermeras, médicos y dentistas de práctica guiada en el pensamiento histórico-político y la reflexión crítica.

Las palabras: Educación Superior, Enfermería, Medicina, Odontología, Pensamiento Crítico 


\section{LISTA DE TABELAS}

Tabela 1 Caracterização dos 18 acadêmicos que constituíram o corpo de sujeitos

página 68 da pesquisa

Tabela 2 Categorização das disciplinas do curso de Enfermagem, conforme o página 247 enfoque

Tabela 3 Disciplinas humanizadoras, na matriz curricular do Curso de Enfermagem

Tabela 4 Disciplinas de interface, na matriz curricular do Curso de Enfermagem

página 248

Tabela 5 Disciplinas de Saúde Pública, na matriz curricular do Curso de Enfermagem

página 248

Tabela 6 Categorização das disciplinas do curso de Medicina, conforme o enfoque

Tabela 7 Disciplinas humanizadoras, na matriz curricular do Curso de Medicina

página 250

Tabela 8 Disciplinas de interface, na matriz curricular do Curso de Medicina

página 250

Tabela 9 Disciplinas de Saúde Pública, na matriz curricular do Curso de Medicina

página 250

Tabela 10 Categorização das disciplinas do curso de Odontologia, conforme o página 251 enfoque

Tabela 11 Disciplinas de interface, na matriz curricular do Curso de Odontologia

página 251

Tabela 12 Disciplinas de Saúde Pública, na matriz curricular do Curso de página 251 Odontologia 


\section{LISTA DE QUADROS}

Quadro 1 Instrumento utilizado nos grupos focais com acadêmicos de Enfermagem, Medicina e Odontologia do último período de uma Universidade Federal da Região Norte do Brasil

Quadro 2 Instrumento utilizado nas entrevistas individuais semi-estruturadas com acadêmicos de Enfermagem, Medicina e Odontologia do último período de uma Universidade Federal da Região Norte do Brasil

Quatro 3 Instrumento utilizado na análise documental para categorização das disciplinas da matriz dos cursos de enfermagem, medicina e odontologia de uma Universidade Federal da Região Norte do Brasil

Quadro 4 Definição de termos, tal como utilizados no presente estudo, que se

página 60 referiram ao ensino tradicional, conforme os trabalhos teóricos de Paulo Freire

Quadro 5 Definição de termos, tal como utilizados no presente estudo, que se página 70 referiram a perspectiva libertadora, conforme os trabalhos teóricos de Paulo Freire

Quadro 6 Instrumento utilizado na análise documental para categorização das disciplinas da matriz dos cursos de Enfermagem, Medicina e Odontologia da uma Universidade Federal da Região Norte do Brasil

Quadro 7 Síntese das perspectivas apresentadas por acadêmicos do último período do curso de Enfermagem sobre o modelo pedagógico do curso

página 144

Quadro 8 Síntese das perspectivas apresentadas por acadêmicos do último período do curso de Enfermagem sobre o enfermeiro

Quadro 9 Síntese das perspectivas apresentadas por acadêmicos do último período do curso de Enfermagem sobre aspectos do trabalho do enfermeiro e seu relacionamento com o paciente

Quadro 10 Síntese das perspectivas apresentadas por acadêmicos do último período do curso de Enfermagem sobre aspectos do trabalho do enfermeiro no serviço de saúde

Quadro 11 Síntese das perspectivas apresentadas por acadêmicos do último período do curso de Medicina sobre o modelo pedagógico do curso

página 145

página 146

página 147

página 206

Quadro 12 Síntese das perspectivas apresentadas por acadêmicos do último página 207 período do curso de Medicina sobre o médico 
Quadro 13 Síntese das perspectivas apresentadas por acadêmicos do último página 208 período do curso de Medicina sobre aspectos do trabalho do médico e seu relacionamento com o paciente

Quadro 14 Síntese das perspectivas apresentadas por acadêmicos do último período do curso de Medicina sobre aspectos do trabalho do médico nos serviços de saúde

Quadro 15 Síntese das perspectivas apresentadas por acadêmicos do último período do curso de Odontologia sobre o modelo pedagógico do curso

página 243

Quadro 16 Síntese das perspectivas apresentadas por acadêmicos do último período do curso de Odontologia sobre o odontólogo

Quadro 17 Síntese das perspectivas apresentadas por acadêmicos do último período do curso de Odontologia sobre aspectos do trabalho do odontólogo e seu relacionamento com o paciente

Quadro 18 Síntese das perspectivas apresentadas por acadêmicos do último período do curso de Odontologia sobre aspectos do trabalho do odontólogo nos serviços de saúde 


\section{LISTA DE FIGURA}

Figura Framework de análise final

página 80 


\section{LISTA DE SIGLAS}

ACS Agente Comunitário de Saúde

AEnf Acadêmico de Enfermagem

AMed Acadêmico de Medicina

AOdo Acadêmico de Odontologia

IES Instituição de Ensino Superior

PSF Programa de Saúde da Família

SUS Sistema Único de Saúde

UBS Unidade Básica de Saúde

USF Unidade de Saúde da Família 


\section{sumário}

Apresentação e abertura

página 01

Capítulo 1 - Contexto e inquietação

O terreno inicial sobre o qual se construiu a presente investigação

página 04

1.1Estado brasileiro e direito à Saúde

página 05

1.2 Saúde da Família

página 09

1.3 Formação universitária em enfermagem, medicina e odontologia no SUS

página 14

\section{Capítulo 2 - Os Pressupostos}

Do marco teórico freireano e seus dizeres sobre humanização

página 27

2.1 A centralidade da educação na temática

página 29

2.2 A humanização

página 32

2.3 Modelos pedagógicos e humanização: postura 'bancária' versus a libertadora

página 36

2.4 Cultura do silêncio na educação

página 40

2.5 Problematização no processo educativo

página 41

2.6 Práxis na educação: ação e reflexão

página 45

2.7 o ensino superior em saúde e o marco teórico freireano

página 46

Capítulo 3 - O Impulso e a direção

Justificativas e objetivos da construção

página 51

3.1 Objetivos da investigação

página 52 


\section{Capítulo 4 - O instrumental e a operacionalização}

Aspectos metodológicos e de percurso da construção

página 54

4.1 Da metodologia

página 54

4.2 Do método: sobre técnicas e seus instrumentos

página 55

4.2.1 Sobre a técnica de grupo focal

página 55

4.2.2 Sobre a técnica de entrevistas individuais

4.2.3 Sobre a técnica de análise documental

4.2.4 Sobre a seleção de sujeitos e a amostra da pesquisa

página 61

página 64

4.2.5 Sobre o tratamento e a análise das informações

4.2.5.1 Definição de termos

4.2.5.2 Tratamento e análise dos grupos focais

4.2.5.3 Tratamento e análise das entrevistas individais

4.2.5.4 Tratamento e análise dos documentos

4.2.5.5 O Framework da análise final: a busca pelo sentido complexo

página 65

página 68

página 68

página 71

página 74

página 74

página 76

4.3 Dos procedimentos: das considerações éticas à condução do presente trabalho

página 80

\section{Capítulo 5 - A imersão}

O produto dialógico do Universo Empírico

página 86

5.1 A perspectivas dos acadêmicos de Enfermagem

5.1.1 O produto do Grupo Focal com acadêmicos de Enfermagem

5.1.1.1 Núcleo Temático 1: Sobre o modelo pedagógico no ensino de Enfermagem

5.1.1.2 Núcleo Temático 2: Sobre o ser Enfermeiro

5.1.1.3 Núcleo Temático 3: Sobre a relação Enfermeiro-Paciente

5.1.1.4 Núcleo Temático 4: Sobre o Enfermeiro e o trabalho no Serviço de Saúde

5.1.2 O produto das entrevistas individuais com acadêmicos de Enfermagem

5.1.2.1 Primeira Categoria: a universidade

5.1.2.2 Segunda Categoria: o professor no ensino de Enfermagem

5.1.2.3 Terceira Categoria: a humanização no modelo pedagógico

5.1.2.4 Quarta Categoria: a humanização na prática de enfermagem

5.1.2.5 Quinta Categoria: desafios à humanização

5.1.2.6 Sexta Categoria: ética, direitos e deveres do paciente

5.1.2.7 Sétima Categoria: prática de enfermagem e saúde coletiva

página 87

página 87

página 87

página 90

página 95

página 103

página 107

página 107

página 110

página 118

página 123

página 130

página 133

página 137

5.2 A perspectivas dos acadêmicos de Medicina

página 148

5.2.1 O produto do Grupo Focal com acadêmicos de Medicina

5.2.1.1 Núcleo Temático 1: Sobre o modelo pedagógico no ensino de Medicina

5.2.1.2 Núcleo Temático 2: Sobre o ser Médico

5.2.1.3 Núcleo Temático 3: Sobre a relação Médico-Paciente

5.2.1.4 Núcleo Temático 4: Sobre o Médico e o trabalho no Serviço de Saúde

5.1.2 O produto das entrevistas individuais com acadêmicos de Medicina

5.2.2.1 Primeira Categoria: a universidade

5.2.2.2 Segunda Categoria: o professor no ensino de Medicina

5.2.2.3 Terceira Categoria: a humanização no modelo pedagógico

5.2.2.4 Quarta Categoria: a humanização na prática de Medicina

5.2.2.5 Quinta Categoria: desafios à humanização

5.2.2.6 Sexta Categoria: ética, direitos e deveres do paciente

5.2.2.7 Sétima Categoria: prática médica e saúde coletiva

página 148

página 148

página 154

página 162

página 172

página 178

página 178

página 181

página 188

página 190

página 196

página 200

página 201 
5.3 A perspectivas dos acadêmicos de Odontologia

página 210

5.3.1 O produto do Grupo Focal com acadêmicos de Odontologia

página 210

5.3.1.1 Núcleo Temático 1: Sobre o modelo pedagógico no ensino de Odontologia

página 210

5.3.1.2 Núcleo Temático 2: Sobre o ser Odontólogo

5.3.1.3 Núcleo Temático 3: Sobre a relação Odontólogo-Paciente

5.3.1.4 Núcleo Temático 4: Sobre o Odontólogo e o trabalho no Serviço de Saúde

5.3.2 O produto das entrevistas individuais com acadêmicos de Odontologia

5.3.2.1 Primeira Categoria: a universidade

5.3.2.2 Segunda Categoria: o professor no ensino de Odontologia

página 212

página 215

página 223

página 225

página 225

página 228

5.3.2.3 Terceira Categoria: a humanização no modelo pedagógico

página 231

5.3.2.4 Quarta Categoria: a humanização na prática de Odontologia

página 233

5.3.2.5 Quinta Categoria: desafios à humanização

5.3.2.6 Sexta Categoria: ética, direitos e deveres do paciente

5.3.2.7 Sétima Categoria: prática odontológica e saúde coletiva

página 236

página 238

página 241

5.4 A análise documental

5.4.1 As disciplinas do curso de Enfermagem

página 247

5.4.2 As disciplinas do curso de Medicina

5.4.3 As disciplinas do curso de Odontologia

página 249

página 251

Capítulo 6 - A emersão e o diálogo

Dialogando com o produto oriundo da ida ao Universo Empírico

página 253

6.1 A emersão dialógica a partir dos universo empírico

página 255

6.1.1 O Enfermeiro, o Médico e o Odontólogo

página 255

6.1.2 O modelo pedagógico na formação

página 266

6.1.3 Sobre as matrizes curriculares no contexto

página 280

6.2 Diálogo contextualizado com os pressupostos freireanos

página 289

Capítulo 7 - A Construção

Algumas considerações finais e o que fica

página 296

Encerramento

página 301

Referências Bibliográficas

página 302

Anexos

Cópia do Ofício do CEP/UFAM autorizando a realização do Projeto

Termo de Consentimento Livre e Esclarecido para os Sujeitos

Matriz curricular do Curso de Enfermagem

Matriz curricular do Curso de Medicina

Matriz curricular do Curso de Odontologia 


\section{Abertura e apresentação}

Em 14 de dezembro de 2001 recebi o Grau de Cirugião-Dentista, no contexto do presente trabalho utilizando-se o termo Odontólogo, por uma das mais bem conceituadas Faculdades de Odontologia do Brasil: a Faculdade de Odontologia de Ribeirão Preto da Universidade de São Paulo.

Em 25 de fevereiro de 2003 fui aprovado ao Grau de Mestre em Ciências Médicas, por outra instituição de ensino de igual destaque: a Faculdade de Medicina de Ribeirão Preto da Universidade de São Paulo.

No dia 30 de janeiro de 2006, matriculei-me em Programa de Pós-Graduação Stricto Sensu, pleiteando caminhar para o se apresenta: o Grau de Doutor. Em Enfermagem. Especificamente: Enfermagem Psiquiátrica pela Escola de Enfermagem de Ribeirão Preto, da mesma Universidade. Unidade de igual significado aos das outras mencionadas acima.

E entre o término de meu mestrado e o início do meu doutorado, tornei-me Especialista em Saúde da Família, através de uma das inúmeras iniciativas do Governo Federal em capacitar os recursos humanos para o PSF. Neste caso, um curso que se propunha a ser multiprofissional, sob responsabilidade do Pólo de Capacitação e Educação Permanente do Nordeste Paulista. 
Não mais como discente, agora como docente, participei, enquanto Coordenador Acadêmico do Instituto de Saúde e Biotecnologia da Universidade Federal do Amazonas, do processo de adaptação da proposta inicial dos cursos de saúde deste Instituto, que resultou no reordenamento de três cursos de saúde que nasceram em 2006, neste Campus do qual sou docente.

Até meu ingresso na carreira docente, atuei clinicamente em duas prefeituras do interior do Estado de São Paulo, na atenção primária de Unidades Básicas de Saúde.

O registro destas informações na presente tese não foi feito nesta abertura apenas como forma do leitor conhecer o ser humano-autor que a construiu. Longe desta intenção, revela o motivo de ser da própria tese: eu, especialista em Saúde da Família por programa do Ministério da Saúde, graduado em Odontologia, me tornei mestre em Ciências Médicas, pleiteando a me tornar doutor em Enfermagem, proponho investigação sobre a formação do enfermeiro, do médico e do odontólogo com relação à sua formação crítico social direcionada à humanização destes profissionais.

E por quê? Justamente pelo que colhi desta vivência: seja como usuário do sistema, seja como discente da educação pública, seja como docente de universidade federal, o SUS pretende algo que não consegue ser. E que muito do que poderia se relacionar aos fatores moduladores deste "não conseguir ser" pode se referir à temática de formar para a humanização.

Nesta intenção, construiu-se esta tese. Construção que foi processo. E como tal, com peculiaridades e reflexos humanos que fogem da capacidade de estrapolação em palavras. 
O primeiro capítulo trata da contextualização da temática da humanização, da formação em Enfermagem, Medicina e Odontologia e os desafios para o SUS.

O segundo capítulo foi construído de forma a revelar a perspectiva utilizada na presente investigação, oriunda do marco de Paulo Freire e referente à humanização.

No terceiro capítulo registram-se as justificativas que levaram ao presente estudo e seus objetivos.

O quarto capítulo debate o percurso metodológico da investigação.

No quinto capítulo, são apresentados os produtos, trabalhados e analisados, oriundos da imersão no Universo Empírico.

O sexto capítulo propõe-se a estabelecer o diálogo entre o que emergiu na investigação e a literatura científica, referindo-se a discussão da presente tese.

E por fim, na presente construção, apresenta-se o sétimo capítulo, o qual se destina a considerações finais e ao que fica. 


\title{
Capítulo 1
}

\section{O CONTEXTO E A INQUIETAÇÃO}

\author{
0 terreno inicial sobre o qual se construiu a presente investigação
}

O próprio título do presente estudo transparece a inquietação que levou a sua consecução: a construção de profissionais de saúde humanizados, na intersecção do modelo pedagógico utilizado na formação universitária e a realidade do atendimento em saúde no Brasil.

Não se trata de uma inquietação apenas do autor. Inúmeros trabalhos científicos e até mesmo ações governamentais demonstram a necessária investigação da formação destes profissionais sob a ótica do relacionamento com os seus pacientes e a orientação da formação aos serviços do Setor Público da atenção em saúde.

Isto posto, o presente capítulo pretende contextualizar quanto às questões da estrutura política do Sistema Único de Saúde, como apresentado pela literatura sobre a questão da humanização e os profissionais de saúde que estão inseridos na Estratégia de Saúde da Família. 


\subsection{Estado brasileiro e direito à Saúde}

No início do século XX, as iniciativas do Estado em relação à Saúde limitavam-se às ações campanhistas enfocando tentativa de erradicação de epidemias, principalmente nas cidades do Rio de Janeiro e Santos, pelo interesse econômico dado se tratarem de cidades portuárias.

Segundo Elias ${ }^{1}$, por influência de modelos de países europeus, o Estado passa em um segundo momento a adotar alguns direitos como aposentadoria, pensão e assistência médica para trabalhadores formais que contribuíam compulsoriamente, através de desconto em folha de pagamento, com recursos financeiro com finalidade de custear tais ações. O processo brasileiro diferiu significativamente do europeu, dado a estas ações se vincularem ao contexto do mundo do trabalho, dado que apenas os trabalhadores dos setores mais dinâmicos da economia foram beneficiados neste momento inicial ${ }^{1}$.

Estes direitos foram ampliados a todos os trabalhadores formais com o passar da história. O modelo entra em crise na década de 1980, por diversos fatores, tais como o investimento no setor privado de saúde através da compra de serviços e falta de investimento no setor público promovendo o sucateamento deste; desvio de recursos previdenciários para outros fins; transição demográfica brasileira, que modificou a relação entre contribuintes ativos e o número de aposentados e pensionistas que se beneficiavam dos recursos ${ }^{1,2}$.

Deste processo acirram-se os debates sobre direito a Saúde e a implicação do Estado nestes, que já haviam sido pelo Movimento de Reforma Sanitária desde os idos da década de 1960, confluindo diversos setores da sociedade na luta por um sistema 
público de saúde que fosse direito de todos os cidadãos. Então, de forma ambiciosa pela primeira vez na história do Brasil, a abrangência do direito a saúde é ampliada a partir dos princípios consagrados no texto da Constituição Nacional de 1988, operacionalizados no SUS, que nasce limitada pelas contradições e limitações da relação Estado/Saúde construídas no transcorrer histórico descrito ${ }^{1-5}$.

Há mudança na relação entre Estado/Saúde quando a Constituição se torna um instrumento legal assegurador do acesso universal e igualitário a todos os cidadãos à promoção, proteção e prevenção de saúde ${ }^{6}$. No entanto, na prática este direito é corrompido conforme o SUS não foi implementado em consonância ao que preconizam seus princípios ${ }^{7,8}$ dado o histórico da articulação entre Estado e Saúde apresentar aspectos desfavoráveis que influenciarão negativamente modulando o processo de implentação do sistema ${ }^{9}$.

Os diversos dilemas entre o SUS preconizado e o SUS de fato provocaram novas discussões sobre a consecução do direito à saúde e a necessidade de reorganização do processo de produção de serviços, sobre tudo a partir da década de 1990, com vistas à implementação efetiva das diretrizes e dos princípios do SUS ${ }^{10}$.

Outro aspecto importante a se ressaltar no contexto é que a Constituição Federal de 1988 registra nos artigos pertinentes a temática, um entendimento de saúde como algo além da ausência de doença, considerando determinantes e condicionantes do processo saúde-doença. Como conseqüência direta há necessidade do SUS responder às necessidades de saúde de maneira ampliada através de ações complexas que incidissem nestes determinantes e condicionantes e não apenas de maneira curativa, enfocando a doença ${ }^{10}$. 
Para Aciole $^{11}$ a construção do SUS está intrinsecamente relacionada ao exercício do controle social, o que faz um inaceitável sem o outro na vivência do profissional de saúde, processo que implica não apenas a construção do SUS, mas que esta construção esteja solidamente embasada em um modelo de gestão participativa.

Neste processo de cidadania há necessidade que o usuário seja tomado como parte ativa, com poderes específicos de atuação neste sistema, se legitimando e efetivamente atuando frente à construção dos sistemas, denunciando suas falhas e optando pelos caminhos em conjunto com os outros atores envolvidos no processo. Mais amplo do que no setor de saúde, os reflexos deste processo de reforma sanitária pode ser entendido como construir o fortalecimento da sociedade civil perante o Estado $^{11}$.

Os aspectos envolvidos na relação entre o usuário, o serviço de saúde e o profissional de saúde no serviço são complexos, dado que a solução de problema de saúde, seja a que nível de atenção se referir, é fenômeno social e histórico que não pode ser analisada como um processo linear, apesar da tradição e estrutura dos sistemas de saúde não se pautarem nesta perspectiva ${ }^{2}$.

Deve ser percebido como um processo em que interagem diversos aspectos concomitantemente, convergindo na dicotomia entre a disponibilidade de um conjunto de ações e serviços e a dificuldade de acesso aos mesmos ${ }^{2}$. Qualquer ação no sistema de saúde deve paralelamente considerar a historicidade, na medida em que existem aspectos íntimos de como o processo de trabalho se dá em cada Unidade de Saúde, com diferentes conformações e espaços ${ }^{2}$. 
No contexto sobre a implementação do SUS os debates firmaram a perspectiva de que não basta aumentar a disponibilidade e o acesso ao atendimento, mas sim a que se pensar em que tipo de atendimento é este. Conforme exposto, no tratamento em saúde não apenas a ação dos técnicos está envolvida no sucesso e na promoção, proteção e recuperação, mas também o comprometimento dos pacientes é de suma importância.

Neste sentido, o debate caminhou para firmar como padrão a ser assegurado o tratamento horizontalizado, em que a equipe de saúde se comprometa em uma postura de similaridade, proximidade e acolhimento das demandas biológicas tanto quanto das demandas emocionais e humanas dos pacientes, na medida em que as normas e os procedimentos por si só não promovem a adesão ao tratamento e muito menos possuem significado frente às demandas não pautadas nas questões que podiam ser respondidas pelo modelo biomédico ${ }^{12}$.

Dado o contexto o Ministério da Saúde desenvolveu estratégias para maior adequação do SUS de fato aos seus princípios, preconizando a superação dos limites da formação tradicional dos profissionais de saúde. Esta superação enfoca-se na exigência de postura humana dos profissionais, os quais devem pautar suas ações no acolhimento, vínculo entre os usuários e equipes, responsabilização, desenvolvimento da autonomia dos usuários e resolutividade da atenção à saúde, princípios norteadores do $\mathrm{PSF}^{12}$. 


\subsection{Saúde da Família}

A criação, implementação e expansão da Saúde da Família foi, portanto, a manifestação da adoção destas perspectivas refletidas em uma política reordenadora da atenção primária, na intenção de se tornar efetivos os princípios do SUS ${ }^{13}$.

Após pouco mais de dez anos da implantação do PSF, há ganhos significativos em termos dos princípios da equidade e da universalidade, dada a priorização pela implantação em áreas que, historicamente, apresentam problemas de acesso aos serviços de saúde ${ }^{13}$.

No entanto, a estratégia não tornou a consolidação da integralidade no SUS mais próxima, como ocorrido em relação aos dois princípios mencionados, mesmo sendo uma estratégia planejada com orientação a objetivos como criar vínculos entre os profissionais e usuários através da co-responsabilização na resolução dos problemas de saúde ${ }^{14-16}$.

Pela importância desses princípios na instituição da Saúde da Família, o PSF pode ser entendido como uma estratégia não apenas para reordenar a atenção primária em termos administrativos, mas principalmente como estratégia de humanização da atenção, haja vista aos objetivos oficiais do Programa encaminhando para a humanização das práticas de saúde, trabalho em equipe multiprofissional de saúde, limite de atuação a uma população adscrita e controle social ${ }^{17}$.

A questão do enfoque humanizador do PSF não se limita a perspectiva apresentada. Antes, a questão do recurso humano na estratégia mostra-se um tema de centralidade, inclusive com o estabelecimento de um novo profissional de saúde: o ACS, que tem peculiaridade na ação humanizadora ao acolher e estabelecer vínculos 
com a comunidade, não apenas dentro das USFs. É profissional imerso na humanidade e no ser humano dos usuários do sistema uma vez que, no mínimo, mensalmente tem um encontro não apenas com o usuário enquanto alguém que se utiliza da unidade de saúde. Tem encontro com a vida e o viver do usuário no contexto de sua residência e de sua família, ao realizar a visita domiciliar. Um encontro com o outro, não focado na doença, mas sim no outro enquanto ser que vive e é articulado em múltiplas interfaces sociais, econômicas e culturais ${ }^{17,18}$.

Neste tocante, a importância da priorização da proximidade do paciente através dos princípios de acolhimento e vínculo refere-se ao protagonismo do usuário do Sistema de Saúde. Protagonismo consolidado ao longo da história do SUS e que ganha visibilidade não apenas no campo da pesquisa em saúde, como também se reflete nas políticas públicas quando as mesmas revelam sua importância no processo de gestão do sistema ${ }^{19}$.

Com a implementação da Saúde da Família, o discurso político governamental se altera e há manifestação operacionalizando fomentos e financiamentos com vistas ao recurso humano em saúde, dada a necessidade de ser reorientado em termos de capacitação para a perspectiva com direção a integralidade e a nova prática em Saúde Coletiva $^{19-21}$.

Apesar da intenção de humanizar a prestação dos serviços de saúde traduzida em diferentes proposições para a capacitação dos recursos humanos que estão atuando no PSF, primando na maioria das vezes pela valorização das inter-relações humanas, os esforços neste sentido se mantêm fragmentados e até mesmo conflituosos com a filosofia que norteia o Programa. Desencontro que alimenta a discussão sobre o 
descrédito e a desconfiança sobre o quanto o SUS de fato é coerente com o SUS idealizado ${ }^{22}$.

A abordagem biomédica ainda permeia a prática no serviço público de saúde brasileiro, mesmo na atenção primária. O enfoque dos profissionais dirige-se a atenção altamente especializada nos diversos aspectos das patologias como locus privilegiado de cura, pensamento que não condiz ao talhe necessário para a atuação do profissional nas USFs ${ }^{23}$.

Outro aspecto importante para a compreensão do modelo do PSF é a centralidade da família na teorização e programação das ações. Há clara reorientação retirando do foco principal a organização das unidades de saúde e re-organizando o local de atuação dos profissionais para além dos limites das USF. Isso decorre da adoção de um novo paradigma sobre o processo saúde-doença em que outros determinantes de saúde que não estritamente biológicos e comportamentais emergem na discussão sobre a intervenção dos profissionais de saúde. O contexto familiar é sobremaneira implicado na questão de saúde neste novo paradigma.

Também integralidade é tomada como conceito em construção permanente, implicando aos profissionais de saúde uma atuação democrática e não centralizada na supervalorização do papel do profissional de saúde, ação do cuidar integrado com outros profissionais e com o próprio paciente e seu entorno sócio-cultural ${ }^{24}$.

Entre diversos aspectos sobre a questão, o presente trabalho adota 0 encaminhamento de que estas ações do Estado refletem eminente busca pela consecução da integralidade. Esta busca se revela na medida em que o paradigma biomédico e seu foco na doença, no atendimento emergencial-curativo, e centralizado 
na figura do médico não se mostrou passível de sustentação em um contexto de Sistema Nacional de Saúde no qual princípios como os do SUS são firmados e reafirmados, seja em âmbito governamental, seja nas discussões nas diversas instâncias do Sistema e junto aos usuários.

A transformação da atenção primária com direcionamento à integralidade apresenta significativa relevância e, em termos pragmáticos e operacionais das unidades de saúde, isso implicará na crescente preconização de uma postura e relacionamento entre equipe e usuário diferente do tradicional, conforme a literatura $^{21,25-31}$.

A integralidade, princípio doutrinário do SUS, é uma diretriz que permeia a história da criação da Saúde da Família.

Da declaração deste princípio no texto da Constituição Nacional de 1988 até a institucionalização do PSF como estratégia estruturante do Sistema de Saúde brasileiro e que, neste contexto, assume relevância política e social nos discursos do Estado, a integralidade vem permeando as discussões entre a teoria e a prática, de forma que a própria adoção da Saúde da Família como modelo de atenção representa intencionalidade em estabelecer a integralidade como uma realidade operacional, não apenas um princípio doutrinário ${ }^{24}$.

É indissociável integralidade da noção de sujeito, que é histórico, possui conhecimentos próprios e não menos importantes que os saberes específicos de saúde. A integralidade apresenta um caráter prático, constituindo-se principalmente como ação de respeito às necessidades dos usuários, em que acolhimento seja entendido como a atenção organizada de forma usuário-centrada pela equipe 
multiprofissional, pensamento divergente do modelo anterior em que a atenção era médico-centrada e a equipe estava sob a autoridade médica, desconsiderando a pertinência de outras questões não biológicas dos pacientes no processo terapêutico ${ }^{24}$.

Na consecução do acolhimento há uma importância singular das relações entre trabalhadores, serviço e usuários, caracterizando a prática da escuta e mútua responsabilização, decorrendo vínculos ${ }^{31}$. Em se constituindo o acolhimento seguido do vínculo neste modelo, há o estabelecimento de um espaço privilegiado de cidadania e democracia, no qual o usuário é visto e vê a si mesmo como cidadão, podendo ser pensada como prática de empoderamento mediatizada na pragmaticidade da observação aos direitos e necessidades dos usuários pelo trabalhador de saúde se utilizar dos recursos e técnicas de saúde ${ }^{32}$.

A literatura científica apresenta que a formação profissional da atualidade em saúde, mesmo quando objetivando estratégias como o PSF, promove uma visão descontextualizada da realidade brasileira. Há contradições entre os princípios em Saúde da Família e o ensino nas IES, a realidade dos serviços de saúde e das comunidades, ainda sendo mantido o enfoque de atenção curativa, individual, com centralidade na doença, havendo certo desconhecimento do entorno sócio-cultural e o contexto das famílias por parte dos profissionais de saúde ${ }^{33}$.

São disparidades do processo de trabalho no PSF que comprometem a legitimidade do modelo de atenção ao não proporcionar soluções adequadas às necessidades da oferta de serviços de acordo com o princípio da integralidade conforme preconizado ${ }^{34}$. Há clara dicotomização entre o projeto do PSF e a sua prática 
cotidiana, na medida em que a equipe ainda vivencia o modelo hegemônico e tradicional, apesar das tentativas de modificá-lo na prática, permanecendo então em um estado entre o PSF idealizado e o PSF de fato ${ }^{34}$.

Neste contexto, o processo de implementação e a realidade atual da Saúde da Família apontam para uma necessidade premente da orientação rumo a um modelo de humanização, que preconize teorização e práticas unidas dentro de uma abordagem mais crítico-social e reflexiva, humanizada e dialógica, conforme preconiza o pensamento de Freire ${ }^{35,36}$.

Com relação à humanização no SUS, paralelamente as ações vinculadas ao PSF, foram estabelecidas outras estratégias.

Em 2001 o Governo Federal instituiu o Programa Nacional de Humanização da Assistência Hospitalar (PNHAH), que propôs mudanças nos padrões de assistência aos usuários no ambiente hospitalar ${ }^{37-39}$.

Em 2003, a proposta de humanização propriamente dita foi expandida para além de o ambiente hospitalar instituindo-se a Política Nacional de Humanização do SUS - HumanizaSUS ${ }^{40-42}$.

\subsection{Formação universitária em Enfermagem, Medicina e Odontologia no SUS}

Cabe aqui reflexão a cerca da formação universitária e este novo contexto da atenção primária. A necessidade de ações governamentais destinadas à capacitação dos profissionais que atuam no sistema público de saúde com vistas à integralidade, 
no mínimo, revela silêncio com relação à sua profissionalização e o enfoque neste princípio do SUS.

Na medida em que a Saúde da Família se tornou o principal modelo de atenção primária no Brasil, a relevância do enfoque humanizador e a ação profissional não pautada apenas nos aspectos técnicos tomam significativa importância no debate sobre a formação universitária.

Outra constatação permite pensar na importância destes temas: o Estado apresenta diversos enfoques para estas temáticas paralelamente a inexistência de estratégias de ações para capacitação em conhecimentos referentes apenas as técnicas do saber clínico, uma vez que o profissional somente pode ser considerado apto ao exercício profissional caso demonstre em uma IES suas habilidades técnicas no transcorrer do curso universitário, implicando em conquistar o direito de documentação que o afirme legalmente como profissional, caso apresente esta capacitação.

Neste novo paradigma de atenção, saúde não pode ser entendida estritamente pelo seu ponto de vista biológico, na medida em que apresenta patente interface e articulação política, estando relacionada à questão de cidadania no Brasil em que se pese, conforme debatido anteriormente, que a Constituição Nacional de 1988 assume saúde como direito de todos os cidadãos e dever do Estado brasileiro, sendo esta questão indissociável da necessidade de formação dos profissionais da área em consonância com este paradigma, uma vez que, apenas assim, o modelo pode ser efetivamente o que se preconiza teoricamente ${ }^{43}$. 
O contexto tem diversas abordagens para análise, inclusive a responsabilização tão somente do profissional na atenção. No entanto, pela perspectiva do assunto utilizada na presente investigação, estes profissionais somente se constituem como tal a partir de suas formações em IES. Formações estas que não se referem apenas educação à formação técnica profissional, mas também a educação referente à postura profissional, com os aspectos humanos da formação.

A concepção pedagógica da IES reflete-se no curso de graduação alicerçando a formação universitária dos enfermeiros, médicos e odontólogos, assim como também em sua atuação posterior a graduação. Neste ínterim, a atuação do professor no processo ensino-aprendizado tem influência na formação do universitário e, dessa forma, na prestação de serviço de saúde.

No paradigma atual sobre saúde, esta é tomada em sua dimensão física e psíquica, com relações entre estas dimensões que não permite uma abordagem real e integral sem considerá-las como aspectos essenciais e não redutível uma a outra. No contexto desta inter-relação destas dimensões está imersa no conjunto dos determinantes sociais implicados na vivência individual. As questões de saúde devem ser abordadas de maneira não-reducionista, re-significando o indivíduo em sua singularidade e subjetividade na relação com os outros e com o mundo, principalmente no âmbito da atenção primária ${ }^{44}$.

Uma formação universitária centrada no modelo técnico e no desenvolvimento restrito de competência técnica não garante o vislumbre do paciente como um todo, inserido em um contexto social, modulador e modulado pela sociedade em que e com a qual está vivendo. 
Nesta concepção pedagógica tradicional, pautada no modelo biomédico, a intervenção se dá somente no ato clínico e é limitada ao atendimento nas Unidades de Saúde, onde o profissional ao encontrar-se com o usuário do Sistema de Saúde age da forma reducionista mencionada. Desconsiderando o contexto subjetivo e sóciocultural do paciente. Desconsiderando que, mais que paciente e profissional, são histórias de vida que se intercruzam, regidas pelos contextos nos quais estão imersos.

A resolutividade da prática de saúde está implicada não apenas no processo diagnóstico e terapêutico, mas na familiaridade, na confiança e na colaboração estabelecidas entre o profissional de saúde e o paciente. Do contrário, o modelo tradicional seria infalível e insubstituível, dado que, além de uma abordagem mais simplista, não seria necessário mudar todo o Sistema e abordagem de saúde do mesmo ${ }^{45}$.

Vale ressaltar o reconhecimento da necessidade de uma maior sensibilidade diante do sofrimento do paciente, considerando-o em sua integridade física, psíquica e social, e não somente de um ponto de vista biológico e biologicista.

Estas reflexões podem ser transpostas para a relação professor-aluno, processo em que também se destaca como fundamental a importância da visão totalizadora de ser humano.

Da mesma forma, há que se considerar a questão da humanização na relação horizontal entre professor e aluno, tudo em vista de sua formação e posteriores conseqüências na postura profissional ${ }^{46}$, implicada na necessidade premente da implementação do modelo de humanização, em consonância com abordagem críticosocial e reflexiva, humanizada e dialógica ${ }^{35,36}$. 
Dadas peculiaridades, o objeto do ensino da saúde deveria ser trabalhado de forma distinta de outras ciências, fugindo da perspectiva reducionista e mecanicista, reduzindo fenômenos complexos às relações causais simples, em que os aspectos sociais, psicológicos e comportamentais são agrupados como determinantes secundários e não significativas frente às questões de cunho biológico no âmbito da saúde $e^{45-47}$.

A humanização da atenção em saúde é uma preocupação não apenas dos pesquisadores da área, mas também do próprio Estado. Está implicada na questão da necessidade de reformulação do modelo pedagógico universitário em consonância com as mudanças do SUS e a observância por parte dos profissionais egressos dos direito a saúde, que no novo paradigma estruturante do modelo de atenção primária significa não apenas a atenção aos cuidados curativos, mas sim a promoção de saúde, demandando capacidade de análise crítica da realidade, da comunidade e de suas manifestações nos campos político, social e cultural. Esta necessidade da formação universitária se adaptar a este contexto é amplamente debatida na literatura científica $^{48-55}$.

Em uma abordagem que contrapõe a idéia geral de que melhoria da saúde deva se traduzir, principalmente, pelo aumento quantitativo do recurso humano e infraestrutura em saúde disponível as populações, cada vez mais a literatura de Saúde Pública fundamenta que estas são dimensões envolvidas na questão. Mas muito longe disto, priorizar apenas o aumento desses recursos não reflete necessariamente na melhoria ansiada. Antes, é necessária a melhoria qualitativa dos recursos humanos, 
indo ao encontro da proposta da presente pesquisa: a consecução de uma formação em saúde que origine um profissional humanizado em termos freireanos.

Cabe ressaltar que humanizar não significa assistencialismo, ou apenas acolhimento e simpatia, no que tange a fundamentação teórica freireana. Ou signifique que o profissional ignore as contradições e os problemas existentes no seu campo de trabalho, apenas tratando o paciente de forma agradável.

Diametralmente a esta postura alienada, o ser humano humanizado em Freire é um cidadão, seja profissional de saúde ou paciente, que se vê com poder de atuar em sociedade, justamente, refletindo nas contradições e nos problemas que a sociedade Ihe traz em seu cotidiano. Sua postura deve refletir seu entendimento de que, antes de ser um profissional, é um ser humano e como tal, não escapa da relação oprimido/opressor, na qual, todos os homens da sociedade capitalista estão inseridos, e, como tal, sofrem, pois que o opressor é tão oprimido pelo sistema como os próprios oprimidos. Estas discussões serão melhor trabalhadas no próximo capítulo em que se debaterá a fundamentação teórica e seus pressupostos.

A consolidação do SUS como um sistema coerente com seus princípios avançou significativamente em temáticas como universalidade ao acesso, controle social e descentralização/municipalização dos serviços de saúde ${ }^{19-21}$. Porém, o distanciamento entre a educação e formação dos recursos humanos e as reais necessidades em saúde ainda apresenta-se como um desafio a plenitude do processo de implantação do sistema, que perpetua o modelo tradicional distanciado do modelo 'usuário-centrado' e do enfoque que realmente atue frente ao cuidado adequado às necessidades da comunidade ${ }^{56-57}$. 
O enfoque pretendido ao profissional para um SUS pleno, dentro de seus princípios e diretrizes, pauta-se na formação generalista, técnica, científica e humanista, com capacidade crítica e reflexiva. Deve estar preparado para atuar eticamente no processo de saúde-doença ${ }^{57}$, realidade muito distante do perfil dos egressos. Mesmo nos cursos de Enfermagem, Medicina e Odontologia, por mais que estes sejam os profissionais de nível superior que atuarão no PSF, apesar dos esforços tanto da gestão do SUS como das IES dada a premente necessidade de incorporação especificamente destas três categorias profissionais no sistema público de saúde devida expansão da Estratégia de Saúde da Família ${ }^{54}$.

As formações educacionais nas três profissões investigadas no presente trabalho apresentam dois nós-críticos: a necessidade de adequação dos profissionais para a imersão nos novos perfis epidemiológicos e demandas sociais, tanto quanto a sua construção junto ao primeiro nível de atenção ${ }^{58}$.

Neste ínterim, a grande dificuldade para a implementação dos princípios do SUS está em que as profissões de saúde pautam-se no paradigma biomédico, de referencial positivista, priorizando os fenômenos biológicos, em cuja prática a doença centraliza-se como tema privilegiado, havendo poucas ações e práticas de enfoquem a formação para a prevenção e para a promoção de saúde na vida da comunidade e dos indivíduos. Os aspectos de prevenção de saúde, cura/reabilitação e promoção de saúde ainda são apresentados de forma desintegrada e, muitas vezes, como se fossem contraditórios e incompatíveis ${ }^{59}$.

Apesar dos esforços, através do PSF, para a efetivação da humanização e integralidade no SUS, não se tem conseguido atingir estes objetivos em decorrência da 
conjuntura envolvida, em que questões políticas, de recursos financeiros, aspectos administrativos e gerenciais do setor público, e o despreparo dos profissionais ${ }^{56}$.

Por vez, o modelo pedagógico em Enfermagem, Medicina e Odontologia não é preocupação apenas do Estado que recebe o egresso e o utiliza como recurso humano nas ações de saúde. Longe de se tratar apenas de um debate pautado nesta abordagem, esta temática surge também na Universidade, em que estes cursos existem, caracterizando a significância e intersetorialidade do tema.

Os desafios no ensino de Enfermagem tangem diversas questões. Existem lacunas a serem preenchidas entre a teoria e a prática, dadas as características do atual contexto em saúde ${ }^{60}$. Isso implica na existência de dificuldades para superação do modelo tradicional em vistas as atuais necessidades em saúde, sugerindo necessária revisão do modelo pedagógico deste curso $^{61}$.

O papel da universidade na formação em Enfermagem não pode ser encarado apenas no aspecto da construção técnica do profissional, mas sim deve ser reorientado para a formação crítica. Apreendedora não apenas das competências técnicas, mas também da visão científica e política, de forma que o enfermeiro possa atuar como cidadão nos diferentes níveis da assistência à população ${ }^{62}$.

Estas necessidades de mudanças no modelo pedagógico de Enfermagem encaminham não somente para a revisão de conteúdos e currículo, mas também para a discussão e reflexão sobre os papéis, tanto do docente como do aluno neste processo, dado que, se o modelo é diferente, não podem permanecer como no modelo que tenta se superar ${ }^{63}$. Apesar da dificuldade para se modificar o modelo pedagógico em Enfermagem, há reconhecimento do próprio corpo docente da 
necessidade de ensino enfocando a complexidade e não apenas os aspectos técnicos e reducionistas da prática profissional ${ }^{64}$.

Com relação à formação universitária médica, o ensino médico deve capacitar pelo conhecimento técnico-biológico, mas não apenas, dadas as mudanças nos serviços de saúde e na sociedade brasileira, este conhecimento não garante ao profissional o entendimento dos aspectos sociais, necessários a um profissional que se paute na ação interdisciplinar e em direção a complexidade das necessidades em saúde ${ }^{65}$.

A literatura científica aponta para a necessidade de reformulação da formação médica, inclusive por que a graduação não garante que o médico, ao ingressar na residência, apresente os conhecimentos básicos para sua especialização nas diversas áreas, indicando que, apesar da fragmentação de conteúdos no curso indicarem aprofundamento de conhecimento médico, na realidade não acontece na prática. Ainda mais em áreas de grande complexidade, tais como a psiquiatria ${ }^{66}$.

Os cursos de Medicina estão tradicionalmente centrados na fragmentação do conhecimento e tomam o hospital como principal centro formador. Este modelo está esgotado e não capacita o discente no cenário real em que sua prática profissional será estabelecida posteriormente a faculdade, ou seja, no âmbito da atenção primária ${ }^{67}$.

O modelo hegemônico na formação do médico brasileiro deve ser revisto. É premente a necessidade de articulá-lo com a realidade, modificando o talhe tradicional dos cursos com a adoção de medidas integradoras entre academia e assistência, desde o início da formação profissional dos estudantes de Medicina. Não apenas nos estágios e etapas posteriores da formação ${ }^{68}$. 
A reformulação do currículo dos cursos de graduação em Medicina é um tema amplamente debatido na literatura científica, sendo que este debate se encaminha para a urgência de direcionamento da formação médica junto à realidade e para a prática nesta realidade, sendo propostas que as estratégias norteiem para a interdisciplinaridade e o trabalho em equipe, além da atenção humanizada ${ }^{69}$. Representando uma transformação que prime pela direção à formação do profissional com vistas à equidade, assistência eficaz e de relevância para o Sistema Público de Saúde ${ }^{70}$.

A temática da reformulação curricular médica não se limita a questão do currículo e da relação teoria/prática, mas, também a própria questão sobre qual definição de saúde pauta as ações e o novo modelo pedagógico, e se realmente este é diferente do tradicional ou apenas se propõe a $\operatorname{ser}^{71}$.

Sobre a temática da formação do odontólogo, os cursos de graduação em Odontologia devem pautar seu modelo pedagógico em uma formação humanística e ética, em que o odontólogo não é apenas um executor clínico, mas sim um promotor de saúde pautado em prática odontológica interdisciplinar no âmbito coletivo ${ }^{72}$.

Este talhe é divergente do tradicional, que prepara para a prática de consultório particular, havendo caráter essencialmente tecnicista, urgindo a necessidade de formar um profissional em outro modelo, pautado nos princípios do SUS e do PSF. No entanto, a literatura científica é ausente na discussão sobre como seria este modelo de prática odontológica divergente da prática tecnicista ${ }^{73}$.

Este debate tem origem em diversos fatores, incluindo o mercado de trabalho do odontólogo que está esgotado para a prática privada tradicional, assim como a 
expansão da Saúde da Família e a inserção do odontólogo em seu corpo mínimo de profissionais, que traz nova realidade a Odontologia no Brasil, implicando em necessidade de reorientação da formação profissional na direção da articulação entre educação superior e serviços de atenção a saúde, enfocando a construção de odontólogos com ênfase na prevenção, promoção, recuperação e reabilitação, com ações pautadas e respaldadas nos princípios do $\operatorname{SUS}^{74}$.

Além destas perspectivas sobre o tema, é importante ressaltar o cenário da qualificação dos docentes dos cursos de Odontologia como determinante no processo de remodelação dos currículos, dado que estes docentes foram formados em uma realidade com características profissionais muito divergentes em relação ao perfil de odontólogo necessário na atualidade, o que implica em dificuldades na adequação da formação do odontólogo a esta realidade ${ }^{75}$, mesmo com o esgotamento do modelo tradicional de educação superior em Odontologia, cuja formação profissional não pode ser dissociada das oportunidades do mercado de trabalho, de forma que o novo perfil deve implicar a satisfação das demandas populacionais na medida em que a Saúde da Família se constitui como oportunidade de trabalho no mercado que, como já mencionado, está em crise ${ }^{76,77}$.

Posto estas considerações, face ao despreparo dos profissionais de saúde em lidar com os usuários de seus serviços, de forma coerente com os princípios do SUS e suas decorrências enquanto práxis profissional, particularmente com relação aos enfermeiros, aos médicos e aos odontólogos por serem os profissionais que tomam frente na Estratégia de Saúde da Família é premente a necessidade de adequação da 
formação da área da saúde, articulando a teoria com a prática, de forma contextualizada.

Há lacunas na literatura quanto à operacionalização deste processo, em que se pese a necessidade de interdependência do Ensino e da Assistência na formação humanizada, trazendo como referência básica e fundamental as questões éticas, tanto no cuidado do paciente, quanto na formação do futuro profissional, efetivando em sua formação acadêmica a relevância do saber perceber e trabalhar os problemas da população, enfocando sua atuação não apenas nos componentes biológicos, mas em outros determinantes do processo saúde-doença.

E mais: a visão sobre estas profissões e processo de trabalho em consonância com o SUS no PSF, dada a peculiaridade do trabalho multiprofissional, precisa de um olhar mais ampliado, não apenas individualizado na corporação profissional de enfermeiro com enfermeiros/equipe de enfermagem, médico com médicos e odontólogo com odontólogos/equipe de saúde bucal.

Mostra-se fundamental no processo, a articulação da formação do enfermeiro, da formação do médico e da formação do odontólogo com a realidade, mas, dadas as implicações mencionadas, se faz necessária a construção de uma formação diferenciada da tradicional. Faz-se necessária a formação integrada e integradora entre enfermeiro, médico e odontólogo no contexto do SUS.

Pela perspectiva dialógica, a fundamentação freireana se mostra coerente com esta proposta.

São características peculiares a este marco: o diálogo entre homens que estão com o mundo, moduladores e modulados por este mesmo mundo e pelas relações 
com seus semelhantes; o significado do ensino e da aprendizagem; os conceitos implicados na visão crítico social da realidade e dos processos humanos; a centralidade do tema humanização.

Nessa medida, optou-se por este referencial teórica para a fundamentação do presente trabalho, em coerência com a pretensão de investigar a formação das referidas profissões no contexto apresentado no presente capítulo. Contexto de tentativa de serem repensadas as práticas de saúde em um enfoque humano, não se distanciando da questão da formação profissional em que o ensino de graduação tem o tom de formar com vistas às atuais perspectivas da reorganização de práticas do SUS através do PSF. 


\section{Capítulo 2}

\section{OS PRESSUPOSTOS}

Do marco teórico freireano e seus dizeres sobre humanização

A escolha do marco teórico estabelecido pelos trabalhos de Paulo Freire para a construção do presente estudo está em consonância com a concepção de Moacir Gagotti de que os pressupostos oriundos do universo conceitual freireano vão além da simples teorização intelectual acadêmica e não se colocam jamais distante da vida vivida, do homem real. Ao contrário, a constante marca da obra de Freire é que "ela exprime a realidade e a estratégia do oprimido" ${ }^{\prime 78}$. É justamente do oprimido, do opressor e do processo opressão/luta contra a opressão que se fundamenta o marco freireano.

Freire é um autor de reconhecimento internacional, principalmente na Educação, mais especificamente nas teorias sobre alfabetização, para a qual dá a importância de possibilitar ao homem ler o mundo. A aproximação do presente trabalho, oriundo das ciências de saúde, e esta fundamentação teórica não se deu por simples opção do autor. Antes disso, trabalhar com a questão da humanização do profissional de saúde é investigar a sua formação profissional em sua origem. E essa investigação envolve o próprio ser humano. 
O processo Ensino/Aprendizagem converge todos os campos da Educação, seja na alfabetização ou no ensino superior em saúde, a este ser humano que, conforme os pressupostos freireanos, está imerso na realidade social a qual modula e na qual é modulado ${ }^{35,36}$

Freire trata em sua obra sobre o oprimido e a sua voz. E não é por que o presente estudo se refere a profissionais altamente qualificados e status social, como o são os profissionais enfermeiros, médicos e odontológos, que não se está se tratando de oprimidos e de opressores.

Oprimidos por sua constituição, como seres humanos no modo de produção capitalista, mão de obra em um mundo do trabalho em transformação, em plena reestruturação produtiva do capital.

Opressores ao reproduzirem no seio de seu trabalho a lógica do modo de produção, com suas hierarquias e seus status adquiridos pelo conhecimento universitário e pela desigualdade social. Opressores ao calar o conhecimento popular e ao prescrever condutas para seus pacientes, ou às categorias profissionais de menor status sob tutela da autoridade que Ihe é legada pelo Sistema de Saúde.

Daí a aproximação do marco freireano no presente estudo.

Despretensiosamente, este Capitulo se propõe fundamentar bases conceituais que permitiram conduzir a investigação, ainda que apresente tão somente aspectos das obras e pressupostos de Freire relacionados à temática, escapando diversos outros do universo freireano, tão complexo. E vivo.

O homem é o ponto central de teorização de Freire. A educação é um momento singular, com possibilidades de fazê-lo melhor quando possibilita a 
percepção crítica de sua realidade. Para a fundamentação freireana "Não há educação fora das sociedades humanas e não há homem no vazio" ${ }^{81}$.

Outra conceituação importante é que o homem está em constante relacionamento, com seus semelhantes e com mundo, não apenas em contato com estes. "É fundamental, contudo, partirmos de que o homem, ser de relações e não só de contatos, não apenas está no mundo, mas com o mundo. Estar com o mundo resulta de sua abertura a realidade, que o faz ser o ente de relações que é" ${ }^{81}$.

\subsection{A centralidade da educação na temática}

A importância da educação no pensamento freireano se demarca conforme a construção dos pressupostos se referencia nesta temática e em suas diversas decorrências na vida humana. "Seres programados para aprender e que necessitam do amanhã como o peixe da água, mulheres e homens se tornam seres 'roubados' se seIhes nega a condição de partícipes da produção do amanhã" ${ }^{84}$.

Estas características levam a reflexão da educação como ato político ${ }^{83,87}$. No universo freireano, a ação educativa é “(...) por sua própria natureza, diretiva e política” ${ }^{83}$, dado que o processo implica em opções políticas de diversos atores: Estado, Sistema Educacional, educadores, educandos, sociedade. “Precisamos, antes de mais nada, entender o contexto social do ensino(...). O professor trabalha a favor de alguma coisa e contra alguma coisa" ${ }^{88}$.

A educação somente é viável ao homem por ser processo de busca da completude, que também implica em seu direcionamento relacional e também 
político. "A educação, portanto, implica uma busca realizada por um sujeito que é o homem. O homem deve ser sujeito de sua própria educação. Não pode ser o objeto dela. Por isso, ninguém educa ninguém." ${ }^{81}$.

No universo freireano a educação é um espaço privilegiado à mudança em sociedade, não com uma visão romântica, em que a salvação da mesma está na educação, já que "não é a educação que forma a sociedade de uma certa maneira, mas a sociedade que, formando-se de certa maneira, constitui a educação de acordo com os valores que a norteiam” ${ }^{80}$. A educação “(...) não é a chave, a alavanca, o instrumento para transformação social. (...) A questão que se coloca ao educador é saber qual é este poder ser da educação, que é histórico, social, político" ${ }^{83}$.

Educar é sim um ato atrevido, no sentido de que a educação e as diversas instâncias possibilitam ao indivíduo pensar, pensar-se e pensar a sociedade em que está inserido. "É preciso que a educação esteja (...) adaptada ao fim que se persegue: permitir ao homem chegar a ser sujeito, construir-se como pessoa, transformar o mundo, estabelecer-se com outros homens relações de reciprocidade (...)"82.

No universo freireano "O homem, por ser inacabado, incompleto, não sabe de maneira absoluta" ${ }^{81}$. A educação tem caráter permanente, por acompanhar a constante mutação dos seres humanos e a história por eles traçada. “O homem não é, pois, um homem para adaptação. A educação não é um processo de adaptação do indivíduo à sociedade. O homem deve transformar a realidade para ser mais" ${ }^{80}$.

A criatividade é outro pressuposto freireano implicado na educação. Ser criativo é ação transformadora da realidade ao "afirmar o homem como homem" 81 . “Em todo homem existe um ímpeto criador. O ímpeto de criar nasce da inconclusão do 
homem. A educação é mais autêntica quanto mais desenvolve este ímpeto ontológico de criar. (...) É necessário darmos oportunidade para que os educandos sejam eles mesmos" $^{81}$.

É o exercício da reflexão e de sua aplicação, avaliando e optando por caminhos, consciente das conseqüências dos atos, não apenas para si, mas para todos os semelhantes, de forma que a criatividade possibilita ao ser humano relacionar-se com os outros homens e com o mundo e, assim, criar sua história. "A Educação deve ser desinibidora e não restritiva. (...) Caso contrário domesticamos, o que significa a negação da educação." ${ }^{81}$.

Conforme os pressupostos freireanos, o homem não pode ser pensado ou analisado como um recorte isolado do contexto em que se insere. Toda e qualquer reflexão deve estar embasada no momento histórico e no lugar em que este homem vive e no seu momento.

A realidade é estipulada pelos homens, entre os homens e para os homens. “Daí ela não pode, por ser histórica tal como os homens que a criam, transformaremse por si só. Os homens que a criam são os mesmos que podem prosseguir transformando-a" 81 .

Nesta criação e re-criação da realidade, a educação como instrumento de democracia é uma importante consideração nos pressupostos freireanos, uma vez que “aprende-se e se ensina democracia fazendo-se democracia. (...) é possível e necessário discutir a presença ou a ausência da prática democrática, as razões de ser $(\ldots)^{\prime \prime} 86$. 
Freire alerta que "ninguém vive plenamente a democracia nem tampouco a ajuda a crescer, primeiro, se é interditado no seu direito de falar, de ter voz, de fazer o seu discurso crítico $(\ldots)^{\prime 27}$. Somente é possível a educação democrática dentro da educação libertadora, uma vez que a democracia pressupõe liberdade.

\subsection{A humanização freireana}

No universo teórico freireano, humanizar é lutar contra a opressão que não permite ao homem pensar-se, aos seus semelhantes e ao mundo com que está de maneira crítica.

Desumanizar é tornar o homem um ser próximo aos animais, que apenas vivem pelo contato. A possibilidade relacional de o homem pensar e atuar conscientemente em sua realidade é característica que o diferencia dos animais. "A captação que faz dos dados objetivos de sua realidade, como dos laços que prendem um dado a outro, ou um fato a outro, é naturalmente crítica, por isso, reflexiva e não reflexa, como seria na esfera dos contatos" ${ }^{81}$

Diferenciar o ser humano do ser animal é uma das preocupações de Freire em sua obra. Muito mais do que o ser biológico, que em nada diferencia sua ação dos animais, os quais apenas regem-se pelo contato entre os semelhantes, não sendo consciente da historicidade que os permeia, o ser humano, pelas características apresentadas anteriormente, pode pensar-se, e pensando-se, atuar conscientemente no mundo e com o mundo. Eis a concepção de homem em Freire. Não poder refletir, 
não poder agir reflexivamente, com criatividade, agindo pela práxis, é deixar de ser humano. É desumanizar.

Ao homem, num processo humanizador, cabe refletir sobre si, sobre seus semelhantes e sobre o mundo em que (e com que) ele está. Para Freire, humanizar é um ato de pensamento crítico reflexivo. "Impedidos de atuar, de refletir, os homens encontram-se profundamente feridos em si mesmos, como seres $(. . .)^{\prime 81}$.

A humanização é tornar humana a ação, transformá-la em simples ato mecânico em ato pensado, dando-lhe um sentido a serviço dos homens. É "compromisso com o mundo, que deve ser humanizado para a humanização dos homens, responsabilidade com estes, com a história" ${ }^{81}$.

Em Freire, humanizar significa imergir-se na realidade "só existe no engajamento com a realidade, de cujas 'águas' os homens verdadeiramente comprometidos ficam 'molhados', 'ensopados'” ${ }^{81}$. E, na vida vivida, humanizar é fazer-se conscientemente presente, "que implica uma responsabilidade histórica, não pode realizar-se através do palavrório, nem de nenhuma outra forma de fuga do mundo, da realidade concreta, onde se encontram os homens concretos $(\ldots)^{\prime \prime 1}$.

Freire propõe a educação voltada para a humanização, que "possibilitasse ao homem a discussão corajosa de sua problemática. De sua inserção nesta problemática" $^{79}$. E a possibilidade da educação interferir na realidade se dá justamente por que, diferente dos animais que simplesmente se acomodam e se ajustam no mundo e aos padrões que este mundo estipula, agindo de maneira reflexa aos contatos que o mundo e os outros animais têm com o primeiro, o homem é um ser de 
integração que tenta "superar os fatores que o fazem acomodado ou ajustado. É a luta por sua humanização, ameaçada constantemente pela opressão que o esmaga"79.

O homem tem sua existência de forma histórica, em contextos da realidade. Contextos concretos, objetivos, mas que, pela característica do homem ter consciência e esta não Ihe permitir apenas sobreviver nesta realidade, mas ao contrário, agir sobre ela e criar a história, o homem é um ser inconcluso, ou seja, não está pronto e não é apenas o fruto do mundo e da história que o precede. Tem capacidade de ser diferente, mediante a sua própria ação moduladora de e modulada por este mundo.

Neste contexto insere-se a questão da humanização em termos freireanos. “(...) a ação só é humana quando, mais que um puro fazer, é um quefazer, isto é, quando também não se dicotomiza da reflexão" ${ }^{35}$.

“Humanização e desumanização, dentro da história, num contexto real, concreto, objetivo, são possibilidades dos homens como seres inconclusos e conscientes de sua inconclusão" ${ }^{35}$. Humanização traduzindo o respeito a esta inconclusão e a conscientização do homem sobre a mesma. E desumanização o contrário.

Assim, a educação tem um papel importante neste processo, na medida em que ensina ao homem padrões e perspectivas deste vir-a-ser; que pode respeitar ou não, na exata medida de ser uma educação humanizadora ou desumanizadora. Na primeira, conforme construída na perspectiva de pedagogia que liberta o oprimido é “aquela que tem de ser forjada com ele e não para ele, enquanto homens ou povos, na luta incessante de recuperação de sua humanidade"35 que lhe é roubada pela estrutura social e opressora do modo de produção capitalista. 
A educação que leva a humanização entende o homem como histórico, social e complexo, postura divergente do ensino tradicional que toma o homem como "coisa", segundo Freire. A tarefa da educação é humanizar o educando. Deve ser pensada no sentido do reconstruir-se dos educandos que se percebem e "(...) é importante que ultrapassem o estado de quase 'coisas'. Não podem comparecer à luta como quase 'coisas' para depois serem humanos"35.

A educação permeia a conscientização do homem sobre a desumanização e a coisificação do educando e dos semelhantes. "É radical esta exigência. A ultrapassagem deste estado, em que se destroem, para o de homens, em que se reconstroem(...). A luta por esta reconstrução começa no auto-reconhecimento de homens destruídos" ${ }^{35}$.

A implicação na humanização e educação é clara para Freire, segundo o qual “não há, porém, humanização na opressão, assim como não pode haver desumanização na verdadeira libertação" ${ }^{80}$.

No entanto, pelo dilema da opressão vivenciado pelos homens dada a estrutura social preponderante no modo de produção capitalista, há uma predileção social pela desumanização, que deve ser combatida pela atitude humanizadora. "Quanto mais o homem é rebelde e indócil, tanto mais é criador, apesar de em nossa sociedade se dizer que o rebelde é um ser inadaptado" ${ }^{81}$. 


\subsection{Modelos pedagógicos e humanização: postura 'bancária' versus a libertadora}

No universo conceitual freireano a educação pode apresentar-se em duas correntes distintas e dicotômicas: a educação tradicional, 'bancária' ou depositária; e a educação libertadora, conscientizadora, crítico-reflexiva ou problematizada.

A educação tradicional é descrita como caracterizada por uma relação narradora, dissertadora do educador para os educandos. "Narração de conteúdos que, por isto mesmo, tendem a petrificar-se ou a fazer-se algo quase morto, sejam valores ou dimensões concretas da realidade" ${ }^{\prime 35}$, pautando-se conhecimento externo aos sujeitos do processo que, pela supervalorização do que é tomado como científico, é inquestionável.

Não existem motivos para os conhecimentos serem refletidos, questionados enquanto verdade ou não, por que a realidade é estática e somente passível de investigação dentro de contextos controlados e imparciais da ciência. Os conteúdos são "retalhos da realidade desconectados da totalidade em que engendram e em cuja visão ganhariam significação" ${ }^{35}$.

A educação tradicional torna a instituição de ensino em um espaço, tipicamente, de "narração ou dissertação que implica um sujeito - o narrador - e objetos pacientes, ouvintes - os educandos. (...) o educador aparece como indiscutível agente, (...) cuja tarefa é 'encher' os educandos dos conteúdos de sua narração"35.

Dos educandos, é exigida a "memorização mecânica do conteúdo narrado. Mais ainda, a narração os transforma em 'vasilhas', em recipientes a serem 'enchidos' pelo educador. (...) quanto mais se deixem docilmente encher, tanto melhores educandos serão"35. 
Não obstante, a denominação educação bancária refere-se ao pensamento de que “(...) a educação se torna um ato de depositar, em que os educandos são os depositários e o educador o depositante. (...) a única margem de ação que se oferece aos educandos é a de receberem os depósitos, guardá-los e arquivá-los"35.

Longe da articulação com a realidade e foco no educando, na educação bancária "o 'saber' é uma doação dos que se julgam sábios aos que julgam nada saber" $^{35}$. O educador tem postura fixa e imutável, "será sempre o que sabe, enquanto os educandos serão sempre os que não sabem. A rigidez destas posições nega a educação e o conhecimento como processos de busca" ${ }^{35}$.

A educação bancária serve ao modo de produção capitalista, desumanizador no sentido de negar ao homem a consciência de sua inconclusão, principalmente por se caracterizar pelo “(...) controlar o pensar e a ação, levando os homens ao ajustamento ao mundo. É inibir o poder de criar, de atuar. (...) ao obstaculizar a atuação dos homens, como sujeitos de sua ação, como seres de opção, frustra-os" ${ }^{\prime 35}$.

Segundo o marco teórico freireano, a educação bancária não permite ao educando uma genuína construção de conhecimento “(...) pois os educandos não são chamados a conhecer, mas a memorizar o conteúdo narrado pelo educador" ${ }^{35}$.

Freire define educação libertadora como a que na relação educador-educandos "deve orientar-se no sentido da humanização de ambos" ${ }^{35}$. “(...) o educador convida os educandos a conhecer, a desvelar a realidade, de modo crítico" ${ }^{80}$. É também o modelo pedagógico "do pensar autêntico e não no sentido da doação, da entrega do saber. Sua ação deve estar infundida da profunda crença nos homens. Crença no seu poder criador $^{\prime \prime 35}$. 
A educação libertadora pauta-se em que “(...) somente na comunicação tem sentido a vida humana. Que o pensar do educador somente ganha autenticidade na autenticidade do pensar dos educando mediatizados ambos pela realidade $(\ldots)^{\prime \prime 35}$.

A realidade, o educador e os educandos têm papel igualmente importante no processo educativo. "Por isto, o pensar daquele não pode ser um pensar para estes nem a estes imposto. Daí que não deva ser um pensar no isolamento, na torre de marfim, mas na e pela comunicação, em torno, repitamos, de uma realidade"35.

No processo ensino-aprendizagem pautado na educação libertadora, a posição do educador frente aos educandos possibilita que não apenas os últimos aprendam. Para Freire "ninguém educa ninguém, como tampouco ninguém se educa a si mesmo: os homens se educam em comunhão, mediatizados pelo mundo. Mediatizados pelos objetos cognoscíveis (...)"

Nesta concepção, a educação libertadora "é humanização em processo, não é uma coisa que se deposita nos homens. Não é uma palavra a mais, oca, mitificante. É práxis, que implica a ação e a reflexão dos homens sobre o mundo para transformá$10^{335}$

O educador libertador, também aludido como educador progressista, deve estar aberto ao diálogo com os educandos e seus mundos, de forma que “(...) deve estar imerso na experiência histórica e concreta dos alunos(as), mas nunca imerso de forma paternalista de modo a começar a falar por eles mais do que verdadeiramente ouvi-los" ${ }^{83}$. "O educador democrático não pode negar-se o dever de, na sua prática docente, reforçar a capacidade crítica do educando, sua curiosidade, sua insubmissão”36. 
A questão da participação dos educandos na discussão de suas próprias questões, é fundamental em uma educação libertadora. “(...) o educador progressista deve estar sempre em mudança, continuamente reinventando-me e reinventando o que significa ser democrático em seu próprio contexto específico cultural e histórico" ${ }^{83}$.

Nesta direção, o educador tem o dever com a coerência de suas convicções e suas atitudes, de forma que, para construir cidadãos, o ensino democrático deve ser coerente com a democracia, ou seja, somente é possível ensinar o acadêmico a respeitar a voz e a vida do paciente no ato da consulta clínica se, a ele mesmo enquanto acadêmico, for dada voz e respeito a sua vida durante o processo ensinoaprendizado.

Em não se aprendendo de modo democrático, não se poderá exercer democraticamente as ações em saúde ou em quaisquer outros campos de atuação. E "quanto mais crítico um grupo humano, tanto mais democrático e permeável, em regra. Tanto mais democrático, quanto mais ligado às condições de suas circunstâncias"79.

Neste processo de construção de postura nos discentes, a importância do ensino problematizado e democrático está implicada, diretamente, na consecução do como o discente construirá sua prática profissional, em conformidade com o universo conceitual freireano.

A educação em que o docente tem posição bancária em nada ou muito pouco contribui para a formação crítico-social, dada suas características narradoras e depositárias. "Tudo ou quase tudo nos levando, desgraçadamente, pelo contrário, à 
passividade, ao 'conhecimento' memorizado apenas que, não exigindo de nós elaboração ou reelaboração, nos deixa em posição de inautêntica sabedoria"79.

Esta concepção se reflete na postura do profissional. A posição cômoda de as coisas estarem como estão e o profissional nada poder fazer. Não aprendeu na graduação a fazer diferente. Como poderia fazê-lo posterior a essa? Eis o profissional inadaptado a estruturas como a do PSF que, conforme descrição do capitulo anterior, exigirá não apenas o conhecimento técnico, mas o exercício democrático e criativo em saúde, primando pela integralidade e pela intersetorialidade.

\subsection{Cultura do silêncio na educação}

Na medida em que Freire alude a educação bancária como “o ato de depositar, de transferir, de transmitir valores e conhecimentos"35, a dissociação entre os conteúdos depositados e a realidade dos educandos é evidente.

É uma educação que reproduz a opressão do modo de produção capitalista e não desenvolve a capacidade de reflexão sobre os homens e o mundo. "Pelo contrário, refletindo a sociedade opressora, sendo dimensão da 'cultura do silêncio', a 'educação' 'bancária' mantém e estimula a contradição"35, mantendo-os silenciosos em relação às condições suas, de seus semelhantes e do mundo com o qual vivem.

Neste sentido, cultura do silencia é o termo que significa a priorização de relações em que não existam diálogo e criticidade, ensinando ao educando que deve se submeter a uma autoridade maior, por esta ter conhecimentos superiores a que, pelo sua ignorância dos mesmos, deve silenciar-se. 
Isto posto, trata-se de estratégia para a opressão, para manter os oprimidos sujeitos aos ditames dos opressores, conforme o que conceitua o pensamento freireano $^{35,36,80}$.

\subsection{Problematização no processo educativo}

A importância da valorização na educação, não apenas dos conteúdos anteriormente elaborados do ser humano mas, também, da realidade e seu potencial junto a processo ensino-aprendizagem, caminhando paralelamente e com a mesma valorização, refere-se no pensamento freireano ao princípio de que o ser humano não está no mundo como um local inócuo, como um palco em que apenas a vida se desenrola.

Distante disso, no universo freireano, o mundo está com o ser humano o qual, constantemente, trava relações com este mundo "que decorre, pelos atos de criação e recriação, o acrescentamento que ele faz ao mundo natural, que não fez, representado na realidade cultural" ${ }^{79}$.

No universo conceitual freireanos "A consciência de si dos seres humanos implica na consciência das coisas, da realidade concreta em que se acham como seres históricos e que eles aprendem através de sua habilidade cognoscitiva" ${ }^{80}$.

Longe de apenas transmitir conhecimentos distantes da realidade, a educação deve se originar na reflexão "sobre o homem em suas relações com o mundo, (...) relações em que consciência e mundo se dão simultaneamente. Não há uma consciência antes disso e um mundo depois e vice-versa"35. 
O conhecimento humano, neste contexto, é mais do que o raciocínio sobre a realidade, mas fruto e fator modulador desta. É resultante da relação entre sujeito (homem) e objeto (mundo) "nestas relações com a realidade e na realidade"79.

O conhecimento para Freire, acontece como característica humana, indistintamente, de escolaridade ou cultura formal. "Basta ser homem para realizá-lo. Basta ser homem para ser capaz de captar os dados da realidade ${ }^{\prime 79}$.

Esta característica, se negada na educação, como acontece com a educação em que o docente ministra conteúdos a discentes passivos no processo, valorizando, exclusivamente, conteúdos pré-definidos, é desrespeitar a humanidade dos discentes, é ignorar esta característica do conhecimento. É descontextualizar o processo ensinoaprendizagem, já que é no mundo real, com a produção pessoal de conhecimento pautado neste mundo, que os futuros profissionais atuarão. Não em situações que simulam a realidade e falam sobre a realidade a partir de laboratórios ou condições controladas.

Neste processo, por sua incessante captação da realidade, através dos problemas que esta para ele são apresentados, o homem aprende a estabelecer nexos e relações que permeiam esta realidade. Com isso, constrói conhecimento.

A proximidade do conhecimento com a realidade é imprescindível por que, "na medida em que o homem, integrando-se nas condições de seu contexto de vida, reflete sobre elas, leva respostas aos desafios que se lhe apresentam" ${ }^{82}$.

No processo educativo, a perspectiva freireana prioriza a formação da consciência crítica no discente, caracterizada pela análise contextualizada da realidade, 
que nesta compreensão é dinâmica, podendo se modificar com o transcurso histórico e circunstancial ${ }^{79}$.

Para entender determinada realidade, a consciência crítica a examina conforme seu conhecimento prévio, mas também sobre o que o momento, o que o empírico lhe traz sobre esta realidade. Que em um segundo momento, pode não ser mais como no primeiro.

A postura contrária a esta é chamada de consciência ingênua, para a qual a realidade é estática e, dessa forma, pode ser reduzida a fórmulas e ao domínio do pensamento intelectual. Sendo assim, o conhecimento pode ser transmitido de indivíduo para indivíduo dada a estabilidade da realidade.

A importância do termo problematização no universo freireano justifica-se nestas concepções descritas. Problematizar é fazer o homem, através da educação se propor como problema a ser investigado ${ }^{35}$. É fazê-lo pensar sobre situações concretas de sua própria existência, como ser histórico e social, por que "a reflexão, se realmente reflexão, conduz à prática"35.

A educação pode desenvolver a consciência crítica ou a consciência ingênua nos discentes, em conformidade com o modelo em que ela se dê.

A vida, o homem no mundo e com o mundo, são direções inerentes a educação para a consciência crítica, dado que o desenvolvimento de habilidades e conhecimentos científicos são importantes e necessários, mas não superam em importância a necessidade de contextualizá-los frente a realidade e aos diversos contextos que a vida e o homem trazem. 
Diametralmente, a orientação da educação para a consciência ingênua, que caracteriza o pensamento bancário, por tomar a realidade como algo estático e perceber o homem no mundo e não com o mesmo, supervaloriza o conhecimento intelectual e técnico, tendo o dever de "submeter-se com docilidade. É próprio desta consciência o fatalismo, que leva ao cruzamento dos braços, à impossibilidade de fazer algo diante do poder dos fatos, sob os quais fica vencido o homem" ${ }^{36}$.

Problematizar é trazer o ensino para a realidade e articulá-lo com esta realidade, para permitir ao educando construir um conhecimento sólido e contextualizado.

$\mathrm{Na}$ problematização do ensino, é necessário o diálogo entre educador e educandos. "É uma relação horizontal (...). Nasce de uma matriz crítica e gera criticidade. (...) Só ai há comunicação. (...) O anti-diálogo que implica numa relação vertical (...), é oposto a tudo isso. Não comunica. Faz comunicados"79.

Enquanto o diálogo é característica do ensino crítico, problematizador e progressista, o anti-diálogo é marca fundamental do ensino depositário, bancário, tradicional.

A importância da educação problematizada pode ser justificada no fato de que “(...) se o pensar só assim tem sentido, se tem sua fonte geradora na ação sobre o mundo, o qual mediatiza as consciências em comunicação, não será possível a superposição dos homens aos homens" ${ }^{35}$, estando intimamente implicada na humanização mediada pela educação. 


\subsection{Práxis na educação - ação e reflexão}

Para Freire, "A consciência crítica não se constitui através de um trabalho intelectualista mas na práxis - ação e reflexão" ${ }^{80}$.

Oriundo do pensamento crítico, a práxis é definida como esta "ação e reflexão sobre a realidade ${ }^{\prime 81}$. Toda e qualquer ação sem a reflexão da realidade, deixa de ser práxis e torna-se ação mecânica, não humanizada.

Entrelaçada à questão da práxis, está o uso da técnica pelos profissionais. $\mathrm{Na}$ concepção freireana há postura profissional que divide os homens entre o "mundo dos técnicos e mundo dos outros homens" é uma instância de desumanização, já que, antes de profissional, trata-se de um ser humano ${ }^{81}$.

Quando o homem se capacita, e se torna profissional de qualquer área, não deixa de ser homem e nem abandona ou supera seu compromisso inerente como tal, no que diz respeito a sua relação horizontal com seus semelhantes e a necessidade de reflexão. Não se exime da necessidade de realizar a práxis.

Na verdade, assume os mesmos compromissos de um homem para com outros homens e, a estes, acrescenta o compromisso pertinente a sua capacitação profissional. "Uma vez que 'profissional' é atributo do homem, não posso, quando exerço um quefazer atributivo, negar o sentido profundo do quefazer substantivo e original" ${ }^{81}$.

Mais do que privilégios, o tornar-se profissional traz intrinsecamente responsabilidades, mediante ao pressuposto freireano de que todo conhecimento e toda produção humana pertencem ao patrimônio cultural da humanidade, na medida em que não há homens que constituam-se como tal sem relacionarem-se 
historicamente com todos outros homens. "Todo amanhã se cria num ontem, através de um hoje. De modo que o nosso futuro baseia-se no passado e se corporifica no presente. Temos de saber o que fomos e o que somos, para saber o que seremos" ${ }^{\prime 80}$.

Esta responsabilidade subjuga o foco exclusivo dos interesses pessoais, fruto de uma postura desumanizada, aos interesses coletivos e, em termos freireanos, que deve ser transformada em práxis.

Cada ato humano tem a consciência por parâmetro, com relação a ser ato humanizador ou desumanizador. Se humanizado, o ato se caracteriza como práxis, ou seja, "é reflexão e ação dos homens sobre o mundo para transformá-lo. Sem ela, é impossível a superação das contradições" ${ }^{35}$.

\subsection{O ensino superior em saúde e o marco teórico freireano}

Na obra de Freire, humanização nunca é entendida como assistencialismo irrefletido, cujo termo utilizado neste universo conceitual é a "falsa generosidade" ${ }^{79}$.

Nas concepções freireanas, o homem é único, não apenas na possibilidade de refletir, dado que a reflexão é um ato tão atrelado ao ser humano, que não é que esta capacidade seja do homem, mas também a necessidade de refletir é humana. Não refletir é desumanizar-se, como já discutido anteriormente.

A técnica jamais deveria suplantar o homem, pela simples ação profissional irrefletida, mítica. “Não posso o me deixar seduzir pelas tentações míticas, entre elas a da minha escravidão às técnicas, que, sendo elaboradas pelos homens, são suas escravas e não suas senhoras" ${ }^{81}$. 
No entanto, sua opção em refletir sobre o exercício técnico, em nada o desmerece ou põe de lado. A técnica tem sim seu papel. Como construção humana, pode mostrar-se como um instrumento humanizador e, por ele, libertador da opressão. "Se o meu compromisso é realmente com o homem concreto, com a causa de sua humanização, de sua libertação, não posso por isso mesmo prescindir da ciência, nem da tecnologia, com as quais me vou instrumentando para melhor lutar por esta causa." ${ }^{81}$.

Neste sentido é que os fundamentos teóricos freireanos valorizam e dão significado ao conhecimento e ao avanço técnico. No entanto, se tratam de desumanização todos atos/posturas nos quais sejam suplantados a cultura e os conhecimentos empíricos do povo, na medida em que provém do ser humano e, como tal, apresentam legitimidade e validade, devendo caminhar, lado a lado, ambos os tipos de conhecimentos.

Ao fazer prevalecer um conhecimento sobre os demais, desumanizam-se ambos os grupos de homens, fragmentando a totalidade que é a realidade, ao se valorizar qualquer aspecto sobre os demais aspectos da cultura humana, patrimônio legítimo da humanidade ${ }^{81}$.

Qualquer abordagem que não esteja em consonância com estes pressupostos direciona à, "para conseguir seus objetivos, ver o homem como uma 'lata vazia' que vão enchendo com seus 'depósitos técnicos'” 81.

O rompimento com a valorização de toda e qualquer produção humana, gera a produção de protocolos e do formalismo técnico. 
Portanto, na concepção freireana, estas instâncias da prática profissional possibilitam a segurança do poder dos profissionais frente ao restante dos oprimidos. Além disso, a simples aceitação dos protocolos garante uma falsa segurança, que não os obriga a refletir e não permite a práxis, que se constitui como evento perigoso e que exige a coragem de pensar e romper com o paradigma da opressão.

Decorrente desta inversão de valores, possibilita-se o exercício profissional mecânico. Não crítico, ao permitir a ação irrefletida quanto à sua importância histórico-social. Não reflexivo, por garantir a falsa segurança de que está tudo transcorrendo como deve ser, por seguir os protocolos e formalismos institucionalizados e cristalizados, não necessitando o profissional de pensar-se e nem aos seus semelhantes no transcurso histórico do processo. Funcionando “(...) como uma espécie de cinto de segurança. Daí o homem alienado, inseguro e frustrado, ficar mais na forma que no conteúdo, ver as coisas mais na superfície que em seu interior" ${ }^{81}$

Para Freire os seres humanos são seres inacabados, termo constantemente utilizado em toda a sua obra. O inacabamento do homem é uma temática sobre a capacidade de vir-a-ser, do potencial de cada qual se tornar mais e melhor do que é no presente. O homem, por estes pressupostos, não é algo completo, acabado, concluído. Diferente disso, é um projeto que pode ou não se tornar diferente.

Como já dito, o que o diferencia dos demais seres vivos é que o homem pode tornar-se consciente deste inacabamento, através da reflexão que o leva a práxis, uma ferramenta na busca pelo suprir o inacabamento humano. 
No universo conceitual freireano, há necessidade de coragem para agir de acordo com estes pressupostos, no sentido de que o homem encontra-se, na sociedade capitalista, sob um constante processo de opressão. Este processo faz com que, pela crise que é experenciada, os homens pensem-se a si mesmos como problema. "Descobrem que pouco sabem de si, de seu 'posto no cosmo', e se inquietam por saber mais" ${ }^{81}$.

Ao realizar este ato de conscientização, direcionam-se a tornarem-se cada vez mais humanos e a perceberem-se como tal. Daí humanizam-se. Eis o processo de humanização freireano. "Estará, aliás, no reconhecimento do seu pouco saber de si uma das razões desta procura. Ao se instalarem na quase, senão trágica descoberta do seu pouco saber de si, se fazem problema a eles mesmos" ${ }^{81}$.

A supervalorização do conhecimento técnico e puramente pragmático, como nos casos da priorização tão somente do desenvolvimento de habilidades técnicas nos cursos superiores em saúde, é tomado prática desumanizadora “(...) que reduz a prática educativa ao treinamento técnico-científico dos educandos. Ao treinamento e não à formação" 84 .

De acordo com os pressupostos freireanos "a necessária formação técnicocientífica dos educandos por que se bate a pedagogia crítica não tem nada que ver com a estreiteza tecnicista e cientificista que caracteriza o mero treinamento" ${ }^{84}$.

Na sociedade atual, a desumanização atingiu tal amplitude, que refletir e trazer ao debate a humanização torna-se cada vez mais necessário. Não apenas para os oprimidos, mas também para os que oprimem, na medida em que somente com os outros homens, podem-se firmar enquanto seres humanos livres. "A desumanização, 
que não se verifica apenas nos que tem sua humanidade roubada, mas também, ainda que de forma diferente, nos que a roubam, é distorção da vocação do ser mais" ${ }^{81}$.

A formação em saúde não se distancia desta realidade. “(...) se nos interessa analisar o compromisso do profissional com a sociedade, teremos que reconhecer que ele, antes de ser profissional, é homem" ${ }^{\prime 1}$.

Tanto quanto qualquer homem, os profissionais de saúde podem estar inseridos em três relações diferentes de comprometimento com os outros profissionais. "Como homem, que não pode estar fora de um contexto histórico-social em cujas inter-relações constroem seu eu, é um ser autenticamente comprometido, falsamente 'comprometido' ou impedido de se comprometer verdadeiramente" ${ }^{81}$.

Nestes pensamentos insere-se o olhar freireano que permeia o presente estudo: fazer refletir o futuro profissional de saúde sobre seu ato, enquanto ser humano, despertar para a necessidade que a formação acadêmica possui em delimitar espaços para que estes pensamentos possam ser levantados, de forma que os profissionais se deparem com seus pacientes em nível técnico de excelência, mas também, como seres humanos que cuidam de outros seres humanos. 


\section{Capítulo 3}

\section{O IMPULSO E A DIREÇÃO \\ Justificativas e objetivos da construção}

A escolha do tema do presente estudo se deu de maneira contextualizada, articulada com a crescente literatura sobre as lacunas referentes à humanização no Sistema Único de Saúde, principalmente no que tange ao despreparo de muitos profissionais de saúde no que concerne ao tratamento humanizado, situação implicada na formação dos recursos humanos em saúde, conforme a literatura apresentada nos capítulos anteriores.

Cada vez mais é preconizada a necessidade de revisão da matriz curricular dos cursos de saúde, em busca de novos paradigmas pedagógicos que possam dar sustentação às mudanças do ensino superior na área.

Conforme debatido no capítulo anterior, a educação pode possibilitar grandes mudanças na sociedade, mesmo que "lenta na tarefa de transformação. (...) Por que ela pode ser transformadora? Por que o trabalho educativo é essencialmente político e é o político que é transformador" ${ }^{89}$.

Isto posto, o presente trabalho propôs se inserir no contexto da formação universitária do profissional de saúde, buscando apreender sua lógica e debater, 
dialogicamente, com base nas informações e na literatura, possíveis caminhos para a formação do aluno de graduação de Enfermagem, Medicina e Odontologia, tendo em vista a construção de um perfil profissional mais humanizado, centrado na problematização e resolução das questões da saúde, não apenas nos seus aspectos biológicos.

Tomando como marco teórico de referência os pressupostos de Paulo Freire, o presente trabalho parte de um olhar crítico-social da Educação Superior em Saúde, em que é valorizado o contexto histórico-político e crítico-social, a problematização, a amorosidade, a cultura do silêncio, o diálogo e a relação horizontal, bem como a articulação da teoria com a prática. Entre outros aspectos, destaca-se sobremaneira a humanização (entendida como cidadania, ética e solidariedade), procurando assim as contradições entre os pressupostos e o processo de ensino/aprendizagem em detrimento da concepção tradicional, nas três profissões de saúde referidas, dada a importância das mesmas para a atenção primária que toma como modelo o PSF.

\subsection{Objetivos da Investigação}

Tomando como base o referencial proposto, o objetivo geral deste estudo foi o entendimento de como o modelo pedagógico universitário pode estar implicado na construção de posturas profissionais humanizadas em futuros enfermeiros, médicos e odontólogos. Especificamente, objetivou-se a partir de uma amostra de estudantes: 
(1) Identificar os componentes curriculares com possibilidade de fornecer aos universitários recursos para sua formação humanista, como as disciplinas embasadas nas ciências humanas, estágios em comunidade, entre outros;

(2) Buscar conceitos e perspectivas dos universitários sobre o modelo pedagógico aplicado em sua graduação, em particular sobre a relação docente-discente;

(3) Averiguar conceitos e perspectivas construídas pelos universitários na sua formação profissional, com especial atenção às questões humanas, ao contexto sócio-cultural dos pacientes, a humanização e a prática de saúde individual e em saúde coletiva;

(4) Analisar a educação universitária destes cursos, tendo como foco central a humanização e os aspectos históricos-políticos/críticos-sociais, fundamentados no marco teórico freireano. 


\section{Capítulo 4}

\section{O INSTRUMENTAL E A OPERACIONALIZAÇÃO \\ Os aspectos metodológicos e de percurso da construção}

\subsection{Da Metodologia}

A opção pela metodologia aplicada nesta investigação refere-se à necessidade de imersão nas características complexas deste estudo sobre modelo pedagógico universitário e da formação de profissionais quanto à humanização, sendo fundamental o entendimento das perspectivas desta realidade e dos aspectos sobre o ser humano envolvido no processo.

A opção pela pesquisa de abordagem qualitativa se dá na tentativa de "compreender um problema da perspectiva dos sujeitos que o vivenciam" medida em que esta abordagem metodológica permite a obtenção de informações sobre aspectos específicos de um fenômeno, no que se refere a sua origem e sua razão de $\operatorname{ser}^{91}$.

Nesta direção, os estudos qualitativos têm a capacidade de incorporar significado e intenção aos atos, às relações e às estruturas sociais, sendo essas últimas tomadas tanto no seu advento como na sua transformação, como construções humanas significativas $^{92}$. 
Trata-se de uma metodologia que abarca aspectos da realidade que escapam a simples quantificação e extrapolações, características da ciência positivista ${ }^{93}$, dado que as pesquisas qualitativas indicam a procura essencial pela natureza dos fatos ${ }^{94}$.

$\mathrm{Na}$ operacionalização da presente pesquisa, por esta se pautar na perspectiva qualitativa, foram utilizadas as técnicas de grupo focal, de entrevistas individuais seguindo roteiro semi-estruturado e análise documental durante a coleta de informações, no sentindo de ampliar a percepção sobre a realidade em que se imergisse.

\subsection{Do método: sobre técnicas e seus instrumentos}

\subsubsection{Sobre a técnica de grupo focal}

A técnica de grupo focal, cujo termo em inglês é focus group, existe desde o início da II Guerra Mundial, por ação de cientistas sociais que usaram a entrevista em grupo focal para determinar a eficiência de programas de rádio destinados a incitar a moral defensiva da população ${ }^{94,95}$.

A técnica de grupos focais trata-se de entrevistas realizadas em grupo, cujo registro produz não apenas a fala dos indivíduos que se alternam na verbalização de seus pensamentos decorrentes das questões provocadas pelos condutores da atividade, mas sim se trata de um produto coletivo, de sentido mais amplo. Sua relevância está na interação entre o grupo, em que as perspectivas individuais se convergem e divergem de posicionamento sobre as questões, o que permite levantar não apenas as diferentes perspectivas de determinada temática, mas também a 
interação destas perspectivas. A técnica apresenta importância e singularidade na medida em que esta dinâmica, entre os diversos olhares do mesmo tema, poderia ser menos acessíveis sem a comunicação e interação na forma de grupo ${ }^{95}$.

A entrevista no grupo focal realiza-se em pequenos grupos. Ao usar esta metodologia, os pesquisadores objetivam apreender conceitos através de discussões sobre conscientes, semi-conscientes e inconscientes, aspectos psicológicos e sócioculturais e seus diversos processos, em diversos grupos. Trata-se de uma tentativa de entender sobre a biografia e a estrutura de vida dos participantes, estrutura esta que interage dinamicamente mediatizada pela discussão disparada por um moderador. A técnica cria uma atmosfera informal que "é intencional e encoraja os sujeitos a falarem aberta e completamente sobre comportamentos, atitudes, e opiniões que eles possuam" ${ }^{94}$.

Além dos aspectos mencionados, o grupo focal tem a peculiaridade de levantar em um curto período de tempo informações sobre um tema específico a partir da visão do público-alvo de interesse para a investigação.

As pessoas que compõe o grupo focal podem ser oriundas de um grupo preexistente, como, por exemplo, trabalhadores de um mesmo serviço, ou organizarse para o objetivo da investigação. Dependendo da abrangência do estudo e da amplitude da perspectiva que se quer construir, o pesquisador pode precisar de mais de um grupo, este de semelhantes ou de pessoas que fazem parte de diferentes etapas de um processo, para chegar a resultados consistentes. Esta técnica deve ser entendida no sentido de buscar informações não de um indivíduo, mas em um grupo já existente ou formado especificamente para um período destinado à coleta de 
dados, que se reúna em torno de um interesse relacionado ao tema da investigação ${ }^{96}$. “O trabalho em grupo explora como as avaliações são articuladas, censuradas, opostas e modificadas através da interação social e como isso se relaciona com a comunicação e estrutura do grupo"${ }^{\prime 97}$.

Esta perspectiva do grupo focal utilizado na produção da interação grupal aponta para quanto seus dados são ímpares ao permitir "explorar como os pontos de vista são construídos e expressos, sendo fundamentais para examinar como o conhecimento, idéias, discursos, apresentações e mudanças lingüísticas operam de um dado contexto cultural”97.

É interessante observar que a técnica se pauta na "fala em debate", onde vários pontos são discutidos, gerando conceitos, impressões e concepções sobre determinado tema, num processo de interação entre os participantes do grupo. As informações são, então, ricas em sua natureza, essencialmente, qualitativa e o limite do debate delineado pela saturação, evidenciado ao moderador pelo esgotamento da existência de falas sobre o tema ${ }^{95}$.

Para a operacionalização desta técnica, a literatura sugere a utilização de um roteiro de questões pertinentes à temática trabalhada no cômputo da pesquisa. Estas questões devem servir como ativadores das discussões, contendo os diversos questionamentos a cerca da temática investigada ${ }^{94-96}$.

As diversas questões utilizadas na realização dos grupos focais tiveram por objetivo levantar a postura dos futuros profissionais frente à questão da humanização dos serviços de saúde, a existência ou não de uma visão crítico-social das ações no campo da saúde e como a formação universitária e o modelo pedagógico dos cursos 
auxiliaram na construção desta postura. Na medida do uso da técnica de grupo focal, o produto originado foi tomado com vistas da construção coletiva, com suas convergências e divergências no próprio grupo de pares, submetidos ao mesmo processo ensino-aprendizagem.

O porquê da opção pela profissão foi inquirido para contextualizar as motivações iniciais que direcionaram os acadêmicos ao curso, questão que podia estar implicada no futuro perfil destes profissionais, com relação a sua maior ou menor humanização. Temática imbricada em o que é ser médico, ser enfermeiro ou ser odontólogo para os acadêmicos dos respectivos cursos, conceitos relacionados ao impulso inicial, mas também à formação universitária, na medida em que estas motivações podem ter sido reforçadas ou diminuídas com o desenvolvimento do curso, na dependência de seus conteúdos.

Estas questões adquirem um significado mais amplo com o questionamento do que é saúde, do que é ser profissional de saúde, dos significados, dos limites e dos prejuízos da atuação destes profissionais sobre a vida das pessoas.

Longe de se traduzirem apenas em reflexões éticas, estas concepções estão implicadas no que é um paciente, no reconhecimento do outro como semelhante, perspectiva de fundamental importância em um olhar freireano, e que deveriam ser construídas junto aos acadêmicos durante o curso universitário, principalmente em se tratando de uma universidade pública como a destes cursos e, por ser pública, direcionada a prática oficial do Estado, ou seja, a do SUS.

A imersão neste universo pretendeu buscar a contribuição do modelo pedagógico universitário para a formação destes profissionais com relação à 
humanização, como se empreende no presente trabalho. Assim, entender como estes acadêmicos percebem a dor no outro, que dor é esta e quanto o profissional de saúde pode atuar nestas questões, são considerações relacionadas à postura mais ou menos humanizada destes futuros profissionais.

Na medida em que a postura crítico reflexiva, pautada no entendimento social do processo saúde doença, é tema privilegiado, foi inquirido sobre a relação entre condições socioeconômicas e às práticas de saúde, buscando apreender como estes futuros profissionais percebem que as iniqüidades sociais são refletidas na saúde da comunidade.

No intuito de registrar se a humanização na atuação destes futuros profissionais de saúde emergiria naturalmente com o desenrolar das discussões ou apenas quando em resposta a uma pergunta específica, a temática esteve presente diretamente e indiretamente em todo o roteiro de entrevistas de grupo focal.

Para a condução do grupo focal do presente trabalho, foram utilizadas as questões norteadoras que constam no quadro a seguir. 
Quadro 01: Instrumento utilizado nos grupos focais com acadêmicos de Enfermagem, Medicina e Odontologia do último período de uma Universidade Federal da Região Norte do Brasil .

\begin{tabular}{|l|l|}
\hline \multicolumn{2}{|c|}{ Questões norteadoras } \\
\hline $\mathbf{0 1}$ & $\begin{array}{l}\text { Falem sobre os motivos pelos quais optaram pelo curso de graduação } \\
\text { que estão prestes a concluir. O que é ser este profissional? }\end{array}$ \\
\hline $\mathbf{0 2}$ & O que é saúde e o que é o profissional de saúde? \\
\hline $\mathbf{0 3}$ & $\begin{array}{l}\text { O que é um paciente? Falem sobre as semelhanças e diferenças dele em } \\
\text { relação ao profissional de saúde. }\end{array}$ \\
\hline $\mathbf{0 4}$ & $\begin{array}{l}\text { Em que as condições sócio-econômicas do paciente interfere em sua } \\
\text { saúde? Há implicação para a prática do profissional de saúde? }\end{array}$ \\
\hline $\mathbf{0 5}$ & $\begin{array}{l}\text { Falem sobre a interferência do profissional de saúde na vida do } \\
\text { paciente. }\end{array}$ \\
\hline $\mathbf{0 6}$ & Falem sobre a dor do paciente. \\
\hline $\mathbf{0 7}$ & $\begin{array}{l}\text { Falem sobre humanização. Este tema foi abordado no curso de } \\
\text { graduação? }\end{array}$ \\
\hline $\mathbf{0 8}$ & $\begin{array}{l}\text { Falem sobre seus professores na graduação. Como eram em relação aos } \\
\text { alunos? }\end{array}$ \\
\hline $\mathbf{0 9}$ & Falem sobre o trabalho em Saúde Coletiva. \\
\hline $\mathbf{1 0}$ & Falem sobre o trabalho em equipe no setor da saúde. \\
\hline $\mathbf{1 1}$ & $\begin{array}{l}\text { Falem sobre as necessidades da população brasileira em relação a sua } \\
\text { futura profissão. }\end{array}$ \\
\hline
\end{tabular}

Sobre a forma de registro das discussões a literatura sobre a técnica sugere que a gravação dos registros sonoros seja a principal maneira de capturar as informações na técnica de grupo focal ${ }^{95-97}$, podendo também ser utilizada a gravação de vídeo. No entanto, há desvantagem desta última forma em relação à gravação em fita cassete que inibe menos os integrantes ${ }^{97}$.

Para facilitar a transcrição, deve ser solicitado aos participantes que falem seus primeiros nomes ao início da gravação, além ser sugerido registro das impressões do pesquisador para aprofundar o conteúdo do material produzido a partir das discussões ${ }^{97}$. 


\subsubsection{Sobre a técnica de entrevistas individuais}

A entrevista individual pode ser definida como "a técnica em que o investigador está presente junto ao informante e formula questões relativas ao seu problema" ${ }^{96}$. Outra definição é de que a técnica é "a simples conversação com um propósito. Especificamente, o propósito é colher informações" ${ }^{94}$.

Uma questão importante é que a entrevista individual é produto da interação entre o mundo que os entrevistados trazem em si e o mundo do pesquisador entrevistador e que a entrevista apresenta uma característica dinâmica “(...) confrontando tanto com a realidade concreta como com as hipóteses e pressupostos teóricos, num processo mais amplo de construção do conhecimento" ${ }^{92}$.

Traduz-se, portanto, em uma forma especial de interação verbal "induzida por determinado fim e limitada a determinada área temática (...). É um modelo em que a relação de papéis entre o entrevistador e entrevistado é sobremodo singular" ${ }^{\prime 98}$.

A entrevista retrata "um processo de interação social entre duas pessoas na qual uma delas, o entrevistador, tem por objetivo a obtenção de informações por parte do outro, o entrevistado". A importância de cada entrevistado aí se justifica, dado que o indivíduo não representa a totalidade das características do grupo a que pertence, mas traz consigo traços comuns aos demais integrantes de seu grupo, o que confere à entrevista a peculiaridade de sua própria perspectiva da realidade vivida ${ }^{91}$.

A técnica apresenta três tipificações: entrevista estruturada, semi-estruturada e não-estruturada, em decorrência do nível de resposta que se objetiva, de forma que na entrevista estruturada ou questionário, as possibilidades de respostas são determinadas previamente pelo pesquisador. No outro extremo, está a entrevista não 
estruturada, na qual se dispara o tema e o entrevistado segue o curso que desejar. Quanto à entrevista semi-estruturada, é um caminho intermediário, em que existe um roteiro de entrevista, com perguntas específicas, no entanto, sem prever as possíveis respostas $^{98}$.

A técnica tem três características principais: (1) a intersubjetividade na coleta de dados; (2) a contemplação da experiência, não apenas de maneira descritiva por parte do pesquisador; e (3) a representação do real através da imaginação. Por estas características, a literatura científica apresenta a técnica com a grande vantagem de descrever a realidade de quem a vivencia, pois não há "ninguém melhor do que a própria pessoa envolvida, para falar sobre aquilo que pensa e sente do que tem experimentado" ${ }^{\prime 96}$.

O uso das entrevistas semi-estruturadas revela seu valor na questão de não se determinar quais as respostas para cada uma das questões pelo pesquisador, havendo a possibilidade de se coletar o ponto de vista dos atores sociais previstos nos objetivos da pesquisa e não as opções oriundas da visão do próprio pesquisador, como no uso de questionário ${ }^{92}$.

Dadas as questões norteadoras que o compôs, o instrumento utilizado para as entrevistas individuais foi construído no sentido de apreender a perspectiva individual sobre a temática do presente estudo.

O modelo pedagógico universitário foi investigado, tanto em sua atribuição de legar competências técnicas específicas de suas futuras profissões, em relação a como foi trabalhado o processo ensino-aprendizagem, com os diversos aspectos da relação entre docentes e discentes no curso. 
Inquiriu-se sobre o paciente e a intersubjetividade na atenção a saúde por parte do profissional de suas futuras profissões, tanto com relação à imagem que apresentavam antes do ingresso na graduação, como na que foram construindo a partir deste e da vivência no meio universitário.

Além dos aspectos mencionados, ainda foi trabalhada a questão da atuação do profissional de maneira relacional, tanto na equipe de saúde, no relacionamento com o paciente e suas ações como ator social.

A seguir encontra-se o instrumento utilizado para as entrevistas individuais e suas questões norteadoras.

Quadro 02: Instrumento utilizado nas entrevistas individuais semi-estruturadas com acadêmicos de Enfermagem, Medicina e Odontologia do último período de uma Universidade Federal da Região Norte do Brasil.

\begin{tabular}{|c|c|}
\hline \multicolumn{2}{|r|}{ Questões norteadoras } \\
\hline 01 & Você se sente preparado, tecnicamente, para atuar como profissional? \\
\hline 02 & $\begin{array}{l}\text { Como você era atendido pelos profissionais da sua futura profissão } \\
\text { antes de ingressar na faculdade? }\end{array}$ \\
\hline 03 & $\begin{array}{l}\text { Existe diferença entre um profissional de saúde e um paciente/cliente } \\
\text { enquanto pessoa? }\end{array}$ \\
\hline 04 & $\begin{array}{l}\text { Existem deveres humanos do profissional no cuidado com seus } \\
\text { pacientes? Se sim, quais? }\end{array}$ \\
\hline 05 & $\begin{array}{l}\text { Existem deveres humanos do paciente para com o profissional quando } \\
\text { está realizando o cuidado? Se sim, quais? }\end{array}$ \\
\hline 06 & $\begin{array}{l}\text { Você se sente preparado para atuar em sua área no atendimento em } \\
\text { Serviço Público de Saúde? }\end{array}$ \\
\hline 07 & $\begin{array}{l}\text { Existe perfil específico para o profissional que trabalha no Serviço } \\
\text { Público de Saúde? }\end{array}$ \\
\hline 08 & Sua futura profissão é uma área que interfere na vida humana? Como? \\
\hline 09 & $\begin{array}{l}\text { Fale sobre a formação do profissional de saúde no ensino superior em sua } \\
\text { área. }\end{array}$ \\
\hline 10 & $\begin{array}{l}\text { Fale sobre a relação professor-aluno no processo ensino-aprendizagem } \\
\text { no nível superior em saúde. }\end{array}$ \\
\hline
\end{tabular}




\subsubsection{Sobre a técnica de análise documental}

A literatura apresenta que documentos são fontes de dados registrados de maneira escrita e que se referem a realidade humana ${ }^{99}$. Como tal, são fonte de informações sobre a vida dos seres humanas e sua história, constituindo-se em um tipo de informação valiosa e que pode ser utilizada em pesquisa ${ }^{99}$.

Na técnica da análise documental, o pesquisador vale-se de documentos em sua forma inicial, sem terem recebido qualquer tratamento analítico. Estes documentos são as chamadas fontes documentais que, pelas características relatadas, não podem ser consideradas como fonte bibliográfica, dado que esta se caracteriza pelo tratamento dos dados por um ou mais autores ${ }^{99-104}$.

O uso de análise documental como técnica de abordagem de dados qualitativos tem importância, "seja complementando as informações obtidas por outras técnicas, seja desvelando aspectos novos de um tema ou problema"105.

Foram investigadas as matrizes curriculares (Anexo III, IV e V) e os Projetos Político-Pedagógicos dos cursos de Enfermagem, Medicina e Odontologia de uma Universidade Federal da Região Norte do Brasil $^{1}$, das turmas de origem dos sujeitos da presente pesquisa, os quais cursavam o último período dos cursos no primeiro semestre de 2007.

Para tanto se utilizou um instrumento de análise, que focalizou o conteúdo das disciplinas, conforme quadro a seguir.

\footnotetext{
${ }^{1}$ Por questões éticas, será omitida a identificação da IES durante o presente trabalho.
} 
Quadro 03: Instrumento utilizado na análise documental para categorização das disciplinas da matriz dos cursos de enfermagem, medicina e odontologia de uma Universidade Federal da Região Norte do Brasil.

\begin{tabular}{|l|l|l|l|}
\hline $\mathbf{0 1}$ Direcionamento da disciplina & sim & não \\
\hline $\mathbf{0 2}$ & $\begin{array}{l}\text { A ementa da disciplina revela conteúdo oriundo da } \\
\text { a ementa da disciplina revela conteúdo oriundo da } \\
\text { área da Saúde Pública? }\end{array}$ & & \\
\hline $\mathbf{0 3}$ & $\begin{array}{l}\text { A ementa da disciplina revela conteúdo oriundo } \\
\text { das Ciências Básicas de Saúde? }\end{array}$ & & \\
\hline $\mathbf{0 4}$ & $\begin{array}{l}\text { A ementa da disciplina revela conteúdo } \\
\text { profissionalizante em Saúde? }\end{array}$ & & \\
\hline $\mathbf{0 5}$ & $\begin{array}{l}\text { Ao analisar a ementa da disciplina, foram } \\
\text { preenchidos 'sim' na questão 01 e 04 }\end{array}$ & & \\
\hline
\end{tabular}

\subsubsection{Sobre a seleção de sujeitos e a amostra da pesquisa}

Na medida em que o presente trabalho se pauta na perspectiva qualitativa, devem ser ressaltados aspectos peculiares com relação a seleção de sujeitos em ambas as técnicas de coleta.

Em conformidade com a literatura, se estipula que número de integrantes do grupo focal tenha que ser de um mínimo tal de sujeitos permitindo o debate intenso e construtivo, mas que não seja grande ao ponto de impedir que todos os integrantes expressem suas opiniões se desejarem. Nesse sentido, cada grupo deve ter, no mínimo, seis e, no máximo, doze integrantes ${ }^{95-97,106}$.

Com relação às entrevistas individuais, sugere-se que sejam entrevistados sujeitos em “(...) número suficiente para permitir uma certa reincidência das informações, porém não despreza informações ímpares cujo potencial explicativo tem que ser levado em conta $[\ldots]^{\prime \prime 2}$. 
Neste talhe de pesquisa "certamente o número de pessoas é menos importante do que a teimosia de enxergar a questão sob várias perspectivas, pontos de vista e de observação" ${ }^{\prime 2}$.

Ainda com relação a entrevista individual, ressalta-se que "a amostra não precisa ser aleatória, nem extensamente numerosa. Em geral, quando os dados se tornam repetitivos, pode-se considerar a amostra suficiente ${ }^{\prime 90}$.

Diversos autores apontam para a necessidade de características ímpares que norteiem o estabelecimento dos critérios de inclusão dos sujeitos, tanto para o grupo focal quanto para as entrevistas individuais, devendo-se obedecer a premissa da existência de, pelo menos, uma característica comum e de interesse, determinada pelo objetivo da investigação $0^{95-97,106}$. A amostra é considerada intencional, portanto ${ }^{96}$.

Neste sentido, foram critérios de inclusão dos sujeitos as seguintes características:

(1) ser discente da Universidade Federal investigada;

(2) cursar Enfermagem ou Medicina ou Odontologia;

(3) estar cursando o último período;

(4) cursar todo o curso na mesma turma que os outros sujeitos do curso.

O último critério de inclusão é justificado pela necessidade de que todos os integrantes deveriam ter sido submetidos ao mesmo currículo e ao mesmo processo ensino-aprendizado.

A inadequação a qualquer um dos critérios acima foi considerada como único critério de exclusão. 
Portanto, integraram o corpo de sujeitos seis acadêmicos do curso de Medicina, seis acadêmicas do curso de Enfermagem e seis acadêmicos do curso de Odontologia, todos alunos do último período da Universidade Federal investigada, em um total de 18 sujeitos.

Os mesmos acadêmicos que integraram os grupos focais foram convidados a participarem de entrevistas individuais. Dos 18 acadêmicos dos grupos focais consentiram em participar das entrevistas individuais cinco acadêmicos do curso de medicina, cinco acadêmicas do curso de enfermagem e cinco acadêmicas do curso de odontologia, totalizando 15 sujeitos. Os três sujeitos que não participaram das entrevistas individuais alegaram falta de disponibilidade de tempo para contribuição com a presente pesquisa.

A tabela a seguir apresenta as características pessoais dos sujeitos, na qual são apresentados todos os sujeitos, dado que mesmo os três que não participaram das entrevistas individuais semi-estruturadas contribuíram com as discussões nos grupos focais. 
Tabela 01: Caracterização dos 18 acadêmicos que constituíram o corpo de sujeitos da pesquisa

\begin{tabular}{|c|c|c|c|c|c|c|c|}
\hline Sujeito & Curso & $\begin{array}{c}\text { Iniciou } \\
\text { outro } \\
\text { curso além } \\
\text { do atual }\end{array}$ & Sexo & Idade & $\begin{array}{c}\text { Estado de } \\
\text { Origem }\end{array}$ & $\begin{array}{l}\text { Integrou } \\
\text { Grupo focal }\end{array}$ & $\begin{array}{l}\text { Entrevista } \\
\text { individual }\end{array}$ \\
\hline Sujeito 01 & enfermagem & $\operatorname{Sim}$ & $\mathrm{F}$ & 23 & Ceará & $\operatorname{sim}$ & $\operatorname{sim}$ \\
\hline Sujeito 02 & enfermagem & Sim & $\mathrm{F}$ & 22 & Amazonas & $\operatorname{sim}$ & $\operatorname{sim}$ \\
\hline Sujeito 03 & enfermagem & Não & $\mathrm{F}$ & 21 & Amazonas & $\operatorname{sim}$ & $\operatorname{sim}$ \\
\hline Sujeito 04 & enfermagem & Não & $\mathrm{F}$ & 20 & Amazonas & $\operatorname{sim}$ & não \\
\hline Sujeito 05 & enfermagem & Não & $\mathrm{F}$ & 22 & Amazonas & $\operatorname{sim}$ & $\operatorname{sim}$ \\
\hline Sujeito 06 & enfermagem & Não & $\mathrm{F}$ & 21 & Amazonas & $\operatorname{sim}$ & $\operatorname{sim}$ \\
\hline Sujeito 07 & medicina & Não & M & 27 & Amazonas & $\operatorname{sim}$ & $\operatorname{sim}$ \\
\hline Sujeito 08 & medicina & Sim & $\mathrm{F}$ & 26 & Amazonas & $\operatorname{sim}$ & $\operatorname{sim}$ \\
\hline Sujeito 09 & medicina & Não & M & 23 & Goiás & $\operatorname{sim}$ & $\operatorname{sim}$ \\
\hline Sujeito 10 & medicina & Não & M & 28 & Amazonas & $\operatorname{sim}$ & $\operatorname{sim}$ \\
\hline Sujeito 11 & medicina & Não & M & 25 & Tocantins & $\operatorname{sim}$ & $\operatorname{sim}$ \\
\hline Sujeito 12 & medicina & Não & M & 23 & Goiás & $\operatorname{sim}$ & não \\
\hline Sujeito 13 & odontologia & Não & $\mathrm{F}$ & 21 & Amazonas & $\operatorname{sim}$ & $\operatorname{sim}$ \\
\hline Sujeito 14 & odontologia & Não & $\mathrm{F}$ & 22 & Amazonas & $\operatorname{sim}$ & $\operatorname{sim}$ \\
\hline Sujeito 15 & odontologia & Não & $\mathrm{F}$ & 22 & Amazonas & $\operatorname{sim}$ & $\operatorname{sim}$ \\
\hline Sujeito 16 & odontologia & Não & $\mathrm{F}$ & 24 & Acre & $\operatorname{sim}$ & $\operatorname{sim}$ \\
\hline Sujeito 17 & odontologia & Não & $\mathrm{F}$ & 23 & Amazonas & $\operatorname{sim}$ & $\operatorname{sim}$ \\
\hline Sujeito 18 & odontologia & Não & $\mathrm{F}$ & 23 & Amazonas & $\operatorname{sim}$ & não \\
\hline
\end{tabular}

\subsubsection{Sobre o tratamento e análise das informações}

\subsubsection{Definição de termos}

Os pressupostos freireanos trabalhados no capítulo anterior legaram o embasamento teórico dos termos utilizados no tratamento e análise de informações do presente trabalho. Com base neste universo conceitual ${ }^{79-88}$, foram construídos os quadros descritivos que se seguem, a fim de nortear as diversas etapas de tratamento e análise das informações no presente estudo. 
Quadro 4: Definição de termos, tal como utilizados no presente estudo, que se referiram ao ensino tradicional, conforme os trabalhos teóricos de Paulo Freire ${ }^{79-88}$.

\begin{tabular}{|c|c|}
\hline Termo & Operacionalização \\
\hline $\begin{array}{l}\text { Educação Bancária } \\
\text { /Tradicional } \\
\text { /Depositária }\end{array}$ & $\begin{array}{l}\text { Prática educativa caracterizada por relações fundamentalmente narradoras, } \\
\text { dissertadoras. Neste modelo, os estudantes são tal como espaços vazios a serem } \\
\text { preenchidos pelo professor. A instrução é moldada, tradicionalmente, como um ato de } \\
\text { depositar, em que os estudantes são os depositários e o professor o depositante. Nesta } \\
\text { estrutura, os conteúdos do professor são transmitidos e os estudantes recebem, } \\
\text { memorizam e repetem. Caracteriza-se, geralmente, pelas seguintes atitudes e praticas } \\
\text { opressivas: o professor ensina e os estudantes são ensinados; o professor coloca-se em } \\
\text { uma posição de que tudo conhece sobre o tema e os estudantes nada sabem sobre; o } \\
\text { professor fala e os estudantes escutam; o professor disciplina e os estudantes são } \\
\text { disciplinados; o professor escolhe e reforça sua escolha, e os estudantes seguem seu } \\
\text { modelo; o professor age e os estudantes têm a ilusão de agir através da ação do } \\
\text { professor; o professor escolhe o programa e o caminho para o ensino e os estudantes } \\
\text { (que não são consultados) adaptam-se; o professor confunde a autoridade do } \\
\text { conhecimento com sua própria autoridade profissional, a qual ajusta na oposição de } \\
\text { aprendizagem, quando os estudantes são meros instrumentos do processo. }\end{array}$ \\
\hline $\begin{array}{c}\text { Educador tradicional } \\
\text { /bancário }\end{array}$ & $\begin{array}{l}\text { Professor que mantém postura pautada na Educação bancária, hierarquizado, } \\
\text { verticalizado, distante e com pouco compromisso com o fato do aluno estar ou não } \\
\text { aprendendo. }\end{array}$ \\
\hline Verticalidade & $\begin{array}{l}\text { Postura em que os atores do processo educacional estão em níveis de importância } \\
\text { diferentes, sendo o professor percebido como figura central e hierarquicamente } \\
\text { superior ao aluno que está inferiorizado e deve ser subjugado no ensino em nome do } \\
\text { aprendizado. }\end{array}$ \\
\hline Cultura do silêncio & $\begin{array}{l}\text { É entendida como uma característica de povos oprimidos dos países colonizados, que } \\
\text { não tiveram possibilidade histórica de expressão em sua sociedade. A cultura } \\
\text { dominante silencia e oprime, através da transmissão cultural de valores e dos discursos } \\
\text { nas escolas e outras instituições que suportam a hegemonia e a ignorância ou } \\
\text { "demonizam" qualquer outro discurso que possa desafiar a autoridade hegemônica. Em } \\
\text { conseqüência, os oprimidos aprendem e internalizam imagens negativas de si mesmos, } \\
\text { por que não são ensinados a utilizar-se de ferramentas como o questionamento crítico } \\
\text { que permitiria que desafiassem estas representações falsas. Ai permanecem como } \\
\text { elementos passivos e silenciosos em relação às contradições do mundo. }\end{array}$ \\
\hline
\end{tabular}


Quadro 5: Definição de termos, tal como utilizados no presente estudo, que se referiram à perspectiva libertadora, conforme os trabalhos teóricos de Paulo Freire ${ }^{79-88}$.

\begin{tabular}{|c|c|}
\hline Termo & Operacionalização \\
\hline $\begin{array}{l}\text { Educação Libertadora } \\
\text { /problematizadora }\end{array}$ & $\begin{array}{l}\text { Educação que leva à conscientização dos estudantes, preparando-os para efetivar seu } \\
\text { processo de ensino em esforço social, destinados à sua própria libertação. Encoraja o } \\
\text { empoderamento estudantil e a crítica, desafiando circunstâncias sociais opressivas e } \\
\text { que ofusquem o trabalho para uma sociedade mais justa. }\end{array}$ \\
\hline $\begin{array}{l}\text { Educador progressista } \\
\text { /libertador } \\
\text { /problematizador }\end{array}$ & $\begin{array}{l}\text { Professor que tem postura pautada na Educação libertadora, portando-se no processo } \\
\text { de ensino de maneira coerente que este "não é uma doação ou uma imposição - um } \\
\text { conjunto de informes a ser depositado nos educandos, mas a devolução organizada, } \\
\text { sistematizada e acrescentada ao povo, daqueles elementos que estes lhe entregou de } \\
\text { forma não estruturada" }{ }^{35} \text {. }\end{array}$ \\
\hline Conscientização & $\begin{array}{l}\text { Se refere a perceber a existência de contradições sociais, políticas e econômicas, } \\
\text { ocorrendo um processo de desenvolvimento de uma consciência crítica, de modo que } \\
\text { os indivíduos possam examinar as ações, indo ao encontro dos elementos opressivos da } \\
\text { realidade. "Sem esta consciência cada vez mais crítica, não será possível ao homem } \\
\text { brasileiro, integrar-se à sua sociedade em transição, intensamente cambiante e } \\
\text { contraditória" }{ }^{35} \text {. }\end{array}$ \\
\hline Método dialógico & $\begin{array}{l}\text { Se refere, no pensamento de Freire, a aprendizagem que abandona o formato da classe } \\
\text { tradicional e aproxima dialogicamente os integrantes do processo ensino- } \\
\text { aprendizagem, sendo oposta a concepção bancária, favorecendo o diálogo entre os } \\
\text { participantes do processo educativo, criando a possibilidade horizontal de comunicação } \\
\text { aberta entre estudantes e professores. }\end{array}$ \\
\hline Humanização & $\begin{array}{l}\text { Termo de fundamental importância no universo dos pressupostos Freireanos. É uma } \\
\text { possibilidade, na medida em que cada indivíduo tem por vocação, tornar-se mais } \\
\text { humano inteiramente, configurando este processo como uma emancipação da } \\
\text { opressão. A instrução pode ser libertadora através da possibilidade de trabalhar no } \\
\text { serviço de vocação histórica da humanidade para tornar-se mais inteiramente humana, } \\
\text { na afirmação e no empoderamento dos estudantes, humanizando as decisões contra as } \\
\text { forças da "desumanização" que oprime os homens e as mulheres em sua dimensão de } \\
\text { seres humanos e limita suas liberdades. Os oprimidos devem aprender a libertarem-se } \\
\text { por si mesmos e, em troca, seus opressores, que também são desumanizados, devem } \\
\text { refletir sobre o processo de oprimir seus semelhantes. Não significa em absoluto } \\
\text { acolhimento e simpatia. Significa no contexto freireano a conscientização, criticidade e } \\
\text { luta pela cidadania de todos. É empoderamento. }\end{array}$ \\
\hline Horizontalidade & $\begin{array}{l}\text { Postura em que os atores do processo educacional estão no mesmo nível. O papel do } \\
\text { professor e do aluno são divergentes quanto a natureza, mas isso não hierarquiza o } \\
\text { professor em relação ao aluno, na medida em que o papel do professor é orientar o } \\
\text { processo que é construído conjuntamente com o aluno. }\end{array}$ \\
\hline Práxis & $\begin{array}{l}\text { É uma atividade complexa que envolve um ciclo de teoria, aplicação, avaliação, reflexão } \\
\text { e retorno posterior à reflexão sobre a teoria. A transformação social seria fruto da } \\
\text { práxis em nível coletivo. Existe a práxis onde existe a ação refletida, que transforma o } \\
\text { trabalho em palavras. }\end{array}$ \\
\hline Problematização & $\begin{array}{l}\text { Processo educacional no qual se refere a rejeição à educação bancária, ou educação } \\
\text { enquanto simples processo de transferir informações, e toma-a como uma } \\
\text { possibilidade para o crescimento individual e coletivo através do diálogo com a } \\
\text { realidade. Os estudantes e os professores transformam-se em co-investigadores críticos } \\
\text { através do diálogo de um com o outro. Para este autor, com a problematização, } \\
\text { ninguém ensina ninguém, nem é ensinado por si mesmo. Os homens ensinam-se, } \\
\text { mediatizados pelo mundo e pelos objetos do conhecimento, que, na concepção } \\
\text { bancária, são de "posse" do professor. Problematizar é partir de quem está } \\
\text { aprendendo, de seus conhecimentos pregressos para então se chegar a finalidade } \\
\text { educacional. É preciso que "os homens se sintam sujeitos de seu pensar, discutindo o } \\
\text { seu pensar, sua própria visão do mundo, manifestada implícita ou explicitamente, nas } \\
\text { suas sugestões e nas de seus companheiros" }\end{array}$ \\
\hline Entorno sócio-cultural & $\begin{array}{l}\text { O complexo, com dimensões sociais, sociológicas, antropológicas, históricas, culturais, } \\
\text { psicológicas, relacionais que constroem e são construídas pelos indivíduos e que, apesar } \\
\text { de muitas vezes corporificadas/emblematizadas no corpo físico, não estão a ele e nem } \\
\text { por ele limitadas. Este entorno é coletivo, histórico, dialógico e dialético. }\end{array}$ \\
\hline
\end{tabular}




\subsubsection{Tratamento e análise dos grupos focais}

O uso de grupo focal vem ganhando visibilidade na pesquisa em saúde, principalmente em situações que se mostram complexas, envolvendo diversos atores ou perspectivas, por se constituir como uma entrevista dinâmica, principalmente no que se concerne à interação entre os integrantes do grupo ${ }^{107}$.

Quanto à unidade de análise para esta metodologia, por ser uma entrevista em grupo, o aspecto coletivo da construção do produto deve ser levado em consideração. "Se não há grupo, não há grupo focal, (...) não sendo uma técnica indicada para determinar os pontos de vistas autênticos dos indivíduos, já que as normas sociais estão implicadas no processo" ${ }^{108}$.

Desta maneira, para análise do grupo focal, deve-se ter em mente que se trata de um produto único, referindo-se ao grupo, não a indivíduos. De forma a não perder esta perspectiva de vista, há necessidade, durante o processo de análise, de que se considerar que "nem os indivíduos nem o grupo se constituem como 'unidades de análise' dissociáveis; ao contrário, os esforços para análise devem procurar um equilíbrio que apreenda a inter-relação entre estes dois 'níveis de análise'”95.

$\mathrm{Na}$ análise dos produtos do grupo focal, o pesquisador "deve procurar distinguir as opiniões individuais semelhantes e contrárias às do grupo e o consenso construído e/ou expresso por ele" ${ }^{97}$, além de que a análise envolve, no mínimo, "extrair e comparar a discussão de temas similares e examinar como esses temas variam entre indivíduos e entre grupos" ${ }^{\prime 97}$.

Assim, no tratamento dos produtos do grupo focal, há necessidade de se ter em mente que, dada a natureza do material produzido, o mesmo retrata um conteúdo 
coletivo e inter-relacional e não simplesmente o agrupamento de posições de indivíduos.

A riqueza de produtos oriunda do uso de grupos focais encaminha a um processo de análise em estágios sucessivos e contínuos, sempre direcionados às propostas e aos objetivos do estudo em que o método foi empregado ${ }^{107,109}$

A construção da análise do produto deve partir dos conceitos iniciais da pesquisa, retornando as intenções do estudo, pautando-se na garantia de que ao realizar o tratamento sejam extraídas informações relevantes, não desprezando as informações significativas de cunho não previsto, mas, ao mesmo tempo, sem fazer com que se perca o foco de análise, deixando de lado as informações irrelevantes ${ }^{109}$.

Cabe ressaltar que, neste processo, se faz necessário, na medida de enfocar claro rigor científico, no sentindo de minimizar a subjetividade na extração das informações relevantes e interpretações dos produtos de pesquisa qualitativa, o que é reduzido pela sistematização do tratamento do material produzido, com um procedimento sistemático, seqüencial, verificável e contínuo ${ }^{109}$.

O modelo de análise empregado nos grupos focais é o mesmo do empregado para análise de entrevistas individuais, com a observação de algumas peculiaridades, como a de considerar o material como um produto coletivo e não oriundo do indivíduo, e também que este processo deve ser desencadeado durante a coleta de informações, em paralelo. Este processo deve ser considerado como uma construção na interpretação das informações, diferente da interpretação ao final do acúmulo de informações ${ }^{109}$. 
A análise do produto do grupo focal visa fornecer tendências, padrões ou parâmetros a partir dos comentários selecionados ${ }^{97}$, assim como opiniões mantidas e expressas freqüentemente, destacando-se as falas que estejam relacionadas às questões norteadoras ${ }^{95,97}$.

A literatura científica apresenta ser necessária não apenas a transcrição das fitas e a leitura destas, mas também escutá-las novamente, até possibilitar clareza no agrupamento e categorização das falas, identificando elementos constantes, em relação ao tema investigado ${ }^{96}$.

O modelo utilizado para análise de grupos focais no presente trabalho é oriundo da síntese da literatura sobre a técnica ${ }^{93-97,107,109}$, referindo-se a etapas no processo: familiarização do conteúdo, identificação da estrutura temática, indexação e recorte, sinterização e interpretação. Cabe ressaltar que na etapa da interpretação, o produto final, depois de tratado, foi confrontado com os pressupostos freireanos explicitados no capítulo anterior, tomando como parâmetro os termos definidos no presente capítulo.

A operacionalização deste processo como um todo será apresentada no desenvolvimento deste capítulo, quando for tratado dos procedimentos do presente trabalho.

Cabe ressaltar que, na medida em que o produto dos grupos focais apresenta o caráter coletivo já referido, optou-se em não identificar os sujeitos na apresentação dos resultados. 


\subsubsection{Tratamento e análise das entrevistas individuais}

As informações oriundas das entrevistas individuais foram tratadas da mesma forma que as do grupo focal, através das etapas para o estabelecimento de categorias conforme a literatura científica pertinente à técnica ${ }^{90-92}$.

Diferente do caráter coletivo dos grupos focais, o produto originado nas entrevistas individuais é pertinente ao próprio entrevistado, sendo que, portanto, houve a necessidade de identificar falas e respectivos sujeitos que as formularam.

\subsubsection{Tratamento e análise dos documentos}

Para a análise dos documentos observou-se modelo existente na literatura ${ }^{110}$, tomando como fonte para a busca de informações as matrizes curriculares dos cursos de Enfermagem, Medicina e Odontologia da Universidade Federal investigada (Anexos III, IV e V), nos quais se procurou identificar apontamentos referentes à temática investigada no ementário de cada disciplina dos respectivos currículos.

Os dados foram analisados por categorização de cada uma das disciplinas após serem realizadas leituras e interpretações do material, à luz do referencial freireano.

Foi investigado o modelo pedagógico dos três cursos da área da saúde mencionado, com relação a sua implicação na humanização do egresso. Para tanto, na análise dos documentos supracitados as disciplinas foram categorizadas conforme a seguir:

(a) disciplinas básicas - cujo conhecimento é correlato às profissões de saúde, dada a importância para que o profissional saiba sobre a composição, 
estrutura e funcionamento biológico do corpo humano, assim como disciplinas básicas para todos os cursos do ensino superior na área das Ciências da Vida;

(b) disciplinas de humanidades - as quais têm origem eminente em conteúdo das áreas das ciências humanas e sociais, e que têm por enfoque a construção de conceitos sociais e humanos nos futuros profissionais de saúde;

(c) disciplinas de interface: apresentam o conteúdo de origem na área de humanidades, mas com direcionamento à área de saúde;

(d) disciplinas de Saúde Pública: aquelas que tem articulação com o trabalho em Saúde Coletiva;

(e) disciplinas profissionalizantes: destinam-se ao ensino-aprendizagem de competências profissionais próprias do curso, preparando o discente para o exercício profissional.

No sentindo de padronizar a categorização, optou-se em utilizar o instrumento a seguir. 
Quadro 06: Instrumento utilizado na análise documental para categorização das disciplinas da matriz dos cursos de Enfermagem, Medicina e Odontologia da uma Universidade Federal da Região Norte do Brasil.

\begin{tabular}{|c|c|c|c|c|}
\hline & Direcionamento da disciplina & $\operatorname{sim}$ & não & categoria \\
\hline & $\begin{array}{l}\text { A ementa da disciplina revela conteúdo oriundo da área } \\
\text { das Ciências Humanas ou Sociais? }\end{array}$ & & & Humanidade \\
\hline & $\begin{array}{l}\text { A ementa da disciplina revela conteúdo oriundo da área da } \\
\text { Saúde Pública? }\end{array}$ & & & Saúde Pública \\
\hline & $\begin{array}{l}\text { A ementa da disciplina revela conteúdo oriundo das } \\
\text { ciências básicas de Saúde? }\end{array}$ & & & Básica \\
\hline & $\begin{array}{l}\text { A ementa da disciplina revela conteúdo } \\
\text { profissionalizante em saúde? }\end{array}$ & & & Profissionalizante \\
\hline & $\begin{array}{l}\text { Ao analisar a ementa da disciplina, foram preenchidos } \\
\text { 'sim' na questão } 01 \text { e } 04\end{array}$ & & & Interface \\
\hline
\end{tabular}

\subsubsection{O Framework ${ }^{2}$ de análise final: a busca pelo sentido complexo}

A associação de diferentes técnicas de coleta de informações na construção do conhecimento é recomendada por diversos autores ${ }^{95,111-114}$.

A opção pelo uso de três técnicas no presente trabalho se deu no sentindo de ampliar o entendimento do contexto da temática investigada, partindo do pensamento de que a realidade é complexa. E, neste particular, parte-se de uma perspectiva dos indivíduos que vivenciam o processo, da coletividade oriunda da vivência destes indivíduos relacionando-se entre si, e da estrutura educacional que forma o arcabouço para esta vivência.

Sobre o uso associado de grupo focal e entrevistas individuais, "a combinação das duas técnicas em projetos de pesquisa pode ser um caminho para explorar, de maneira mais eficaz, o que cada uma delas $\operatorname{traz}^{\prime \prime 9}$.

\footnotetext{
${ }^{2} \mathrm{O}$ termo Framework tem o sentido de modelo ou estrutura em que a análise se baseaou. Optou-se pela utilização do termo em inglês por ser a forma mais utilizada no meio acadêmico.
} 
A realização inicial da técnica de grupo focal e posteriormente da técnica de entrevistas individuais com os mesmo sujeitos tem justificativa na literatura, na medida em que o grupo focal pode prover um ponto de partida para os aprofundamentos que as entrevistas individuais podem permitir. O uso simultâneo nos sujeitos permite confirmar ou não impressões que o pesquisador possa ter quando da realização de cada uma das técnicas, possibilitando uma maior certeza na extrapolação das interpretações, a partir dos dados empíricos ${ }^{95}$.

Outro aspecto do uso associado das técnicas é que, enquanto a entrevista individual traz informações do sujeito sobre sua vivência no tema, o grupo focal permite observar as interações a partir dos tópicos das discussões, enriquecendo ainda mais o material final da pesquisa. Enquanto o grupo focal garante o que se produz em termos do tema da interação entre as pessoas, a entrevista individual permitirá o detalhamento e a particularização do que cada indivíduo pode contribuir para o entendimento do tema, sendo extremamente válida a utilização associada de ambas as técnicas ${ }^{94}$.

Dessa forma, o uso atrelado de grupo focal com entrevistas individuais tem sentido, na medida em que "permite verificar a convergência entre as manifestações coletivas e individuais, favorecendo a identificação e análise de aspectos relevantes para o entendimento do assunto estudado" ${ }^{97}$.

A utilização das três técnicas permite a investigação da temática em duas dimensões: a dimensão dos que vivenciam a realidade do ensino - através dos grupos focais (sentido coletivo) e entrevistas individuais (sentido indivíduos) - e a dimensão 
do modelo pedagógico estruturante desta realidade de ensino - através da análise documental.

O marco teórico freireano tem pressupostos, como expostos no capítulo anterior, que encaminham para o entendimento da realidade como um produto do indivíduo, da coletividade e da estrutura, já que "não estamos somente 'no' mundo, mas também 'com' o mundo, que é, essencialmente relacionado ao homem", e que esta forma de pensar é no sentido mais radical do mundo como nosso mundo ${ }^{36}$.

Na busca deste sentido amplo, apesar da particularização de cada técnica, a análise utilizada no presente trabalho segue o framework baseado nesta busca por perspectiva contextual e "hominizada" do processo ensino-aprendizagem, que ficará mais clara na discussão a ser empreendida no capítulo seis deste estudo.

Apesar de a literatura científica apresentada sugerir o uso da técnica de grupo focal e de entrevistas individuais em paralelo em um mesmo estudo, não foi encontrado na literatura utilizada um modelo de como promover a análise conjunta destas técnicas.

Então, frente a necessidade de operacionalizar a análise, estabeleceu-se um facilitar a análise e na busca da existência de reincidirem informações entre grupos focais e entrevistas individuais, optou-se por denominar como Núcleo Temático a unidade que reunia falas que se referiam ao mesmo tema no produto dos grupos focais. A opção pelo termo Núcleo foi tomada em alusão ao caráter coletivo do produto dos grupos focais. Denominou-se de Categoria as falas que tinham mesmo significado dentro das entrevistas individuais, dado que este é o termo mais empregado no tratamento de depoimentos oriundos desta técnica. 
Após o estabelecimento dos Núcleos Temáticos e Categorias, foi realizada a análise do material tratado para cada grupo, caracterizada para o presente trabalho como a busca de pensamentos, conceitos e perspectivas comuns entre os Núcleos Temáticos e as Categorias e, por isso, chamada de Convergências. Para este processo, foi utilizada uma tabela de síntese, em que foram registradas as idéias de cada Núcleo Temático e às Categorias cujos temas podiam ser associados. Foi então promovida a investigação de pensamentos semelhantes conforme descrita, e registrada na coluna indicativa da Convergência.

Por fim, na premissa de apreender o sentido geral do contexto, promoveu-se diálogo e discussão entre: (1) o resultado da análise documental de cada curso; (2) as Convergências de cada curso com as dos demais; e (3) a literatura científica em saúde e pedagogia.

A figura a seguir representa o framework referido. 


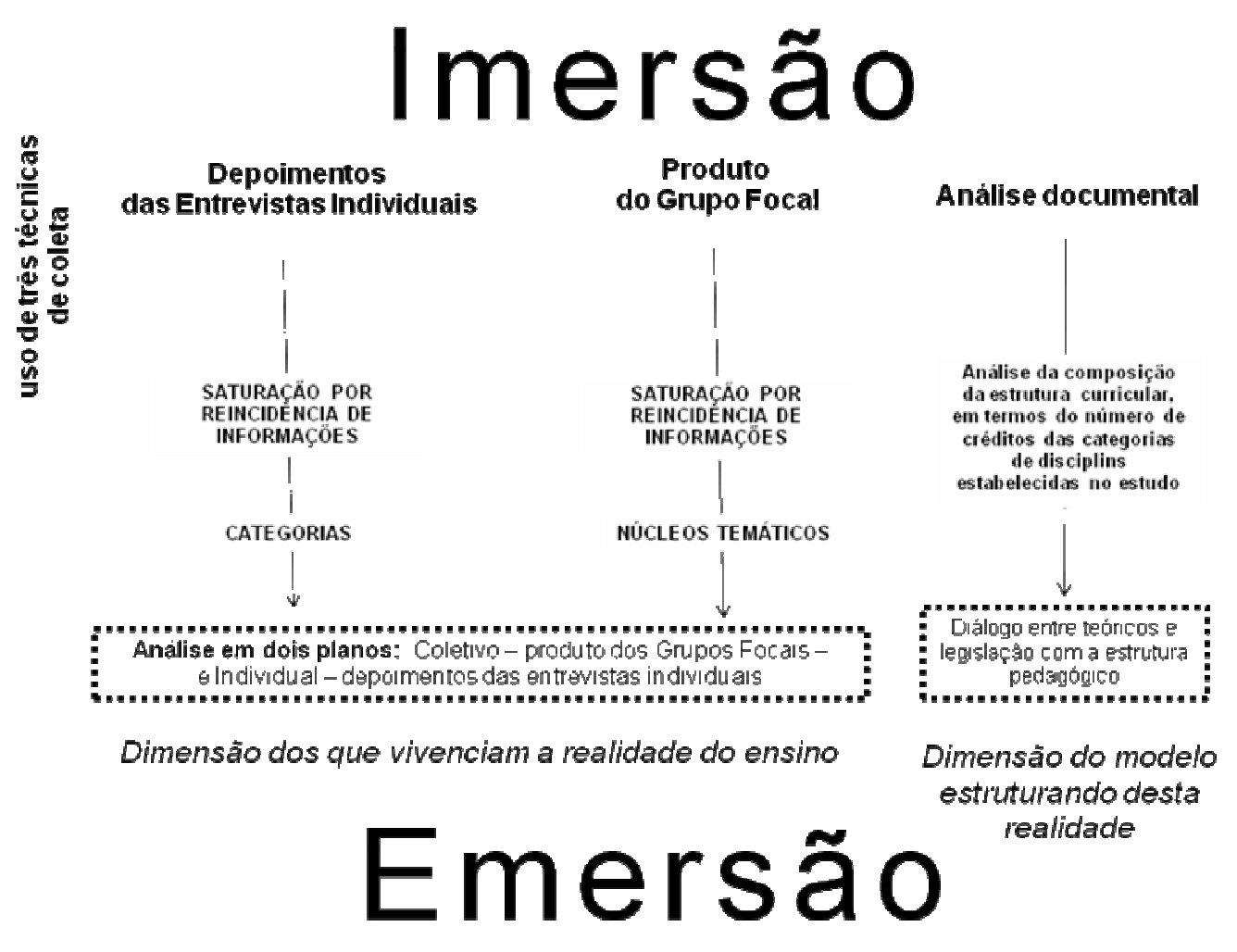

Figura: Framework de análise final

O que emergiu deste processo produziu o que está registrado no sexto capítulo do presente trabalho.

\subsection{Dos procedimentos: das considerações éticas à condução do presente trabalho}

Após a construção do projeto de pesquisa, foram iniciadas as tramitações necessárias para a consecução da mesma.

A pesquisa que originou o presente trabalho foi conduzida de acordo com as normas que versam sobre pesquisa com seres humanos no Brasil, sendo o primeiro dos procedimentos, a solicitação de permissão para a Instituição à realização da 
pesquisa, requisito imprescindível quando da submissão do projeto ao Comitê de Ética em Pesquisa da Universidade Federal do Amazonas (CEP/UFAM), que foi aprovado sob o protocolo 230/2006, conforme cópia do Parecer (Anexo II).

A coleta de informações foi realizada durante o $1^{\circ}$ Semestre de 2007 , em salas cedidas pela própria Universidade Federal da Região Norte do Brasil, que aceitou participar da investigação.

Os sujeitos foram contatados durante os dias letivos, nos edifícios em que o último período de cada curso tem suas atividades de ensino, momento em que foram explicados os objetivos e procedimentos da pesquisa, convidando aqueles que desejassem participar, a deixar telefone de contato com o pesquisador.

Após conseguir o número mínimo para a condução de grupos focais, o pesquisador agendou com os sujeitos o encontro que, em conformidade com a literatura, tiveram duração entre uma hora e meia à duas horas, haja vista a necessidade de tempo para a interação entre o grupo, mas sem a extrapolação de tempo evitando com isso fadiga entre os participantes.

Somente foi iniciado qualquer procedimento de coleta de informação, após a leitura e explicação do Termo de Consentimento Livre e Esclarecido (Anexo I) aos entrevistados, cujo consentimento em participação foi registrado com a assinatura por todos de duas vias do referido termo, ficando uma em suas posses e a outra em posse do pesquisador.

As entrevistas individuais foram realizadas nas dependências da mesma Universidade, por livre escolha dos entrevistados, cabendo ao entrevistador apenas se 
certificar que o local escolhido seria adequado para a tomada dos depoimentos, no sentido de preservar o sigilo e não haver transtornos durante a entrevista.

Conforme a literatura, o registro dos grupos focais e entrevistas individuais foram realizados através de gravação em fita magnética com gravador eletrônico, como forma de registro durante a utilização da técnica, com o pleno conhecimento e consentimento dos sujeitos.

Todo o material gravado por ambas as técnicas foram transcritos na íntegra, por um técnico de pesquisa com experiência em transcrição, que foi pago para efetuar o serviço.

As cinco horas e trinta minutos de gravação dos grupos focais levaram cerca de vinte e cinco horas para serem transcritas, resultando em noventa páginas de discursos.

Com relação ao material das entrevistas individuais, cada uma durou em média uma hora, resultando em dez horas de gravação, levando-se cerca de cinqüenta horas de transcrição, resultando em duzentas páginas.

O modelo utilizado para análise de grupos focais foi o descrito anteriormente, seguindo os procedimentos que s seguem.

Para familiarização do conteúdo foram ouvidas diversas vezes todas as fitas cassetes de registro dos conteúdos dos grupos focais. A seguir, foram lidas as transcrições destas mesmas fitas. Durante este processo o pesquisador fazia anotações pertinentes ao conteúdo, com a principal intenção de imersão no produto e, a partir disso a emersão dos temas maiores existentes no produto dos grupos focais. Esta etapa fundamentou a estrutura temática, que foi registrada através de notas do 
pesquisador ao longo do texto escrito, identificando as principais idéias e conceitos que emergiram do produto do grupo focal e que foram utilizadas no desenvolvimento das categorias de análise.

A organização do material pautou-se nestas categorias emergidas do processo a partir do destaque de algumas falas do todo de cada produto do grupo focal, seja em por conteúdo coerente ou por conteúdo contraditório tendo como base o referencial teórico freireano.

Nesta etapa, cada categoria consiste em falas isoladas do produto total do grupo focal e que apresentam elementos de discurso em comum.

As categorias semelhantes foram reunidas por proximidade de conteúdo, com relação a coerência ou divergência frente ao referencia teórico de Freire, nos já referidos Núcleos Temáticos, os quais retratam temas gerais de importância para a temática do presente estudo.

Optou-se pelo estabelecimento de quatro núcleos temáticos.

As categorias inscritas no primeiro núcleo temático referem-se às impressões a respeito do modelo pedagógico empregado durante a graduação.

O segundo núcleo temático trata das dimensões do que é ser enfermeiro, ser médico ou ser cirurgião dentista e a temática da humanização.

No terceiro núcleo temático, a discussão encaminha-se para as questões do profissional e sua relação com o paciente, enquanto o quarto núcleo temático referese ao profissional e o trabalho em saúde.

Ressalta-se novamente que não foram identificados os sujeitos que emitiram as considerações durante os trabalhos dos Grupos Focais. Esta opção parte da 
compreensão por parte do autor de que cada consideração ou fala é um produto coletivo, cujos sujeitos são interlocutores das perspectivas deste todo coletivo. Isso se evidencia quando componente ou componentes de cada grupo não concordam com o que é exposto e ocorre polarização do produto do grupo focal com a expressão de produto divergente.

Foi então desenvolvido o processo interpretativo, em que cada categoria foi descrita, tanto em seu conteúdo explicito como implícito e seus silêncios, análise esta que se pautou nos pressupostos freireanos, delimitados anteriormente, na descrição de termos do presente capítulo.

O processo de tratamento das informações oriundas das entrevistas individuais foi o mesmo que o utilizado para o tratamento dos produtos dos grupos focais, com a particularidade de se identificar o emitente das falas, na medida em que estas retratam sua construção pessoal e não uma construção coletiva como no grupo focal. Outra peculiaridade, explicada anteriormente, foi o agrupamento das falas em Categorias.

Com relação a estas técnicas e o framework utilizado, foi confeccionado para cada um dos cursos quadros sintetizando as principais idéias de cada Núcleo Temático e categorias das entrevistas individuais que estão relacionadas a estes e que objetivavam aprofundar seu sentindo, buscando apreender a perspectiva sobre a temática na dimensão dos que vivenciam a realidade.

No que se refere aos procedimentos para a análise documental empreendida, foi efetuada a leitura dos Projetos Político-Pedagógicos dos três cursos. 
A seguir, utilizando o instrumento já referido para este fim, tipificou-se as disciplinas quanto ao direcionamento registrado no Ementário, referente a formação do profissional.

Utilizou-se então, o método quantitativo descritivo para estabelecer o percentual de cada uma das categorias de disciplinas na formação, possibilitando a análise comparativa intragrupo e intergrupos.

Esta etapa da análise documental, como já referido, relaciona-se a análise da dimensão do modelo pedagógico que estruturante desta realidade de ensino concebida pelo Framework apresentado.

A análise final, buscando o sentido complexo, que abarca ambas as dimensões e mais, foi empreendida no capítulo sexto, quando as diversas informações são discutidas à luz da literatura crítico social de Paulo Freire, de autores do pensamento crítico e de autores da pedagogia crítica. 


\section{Capítulo 5}

\section{A IMERSÃO}

O produto dialógico do Universo Empírico

Este Capítulo objetiva a apresentação das informações originadas do universo empírico, no sentido do leitor apreciar a diversidade e riqueza das informações. Não a simples apresentação, mas sim o diálogo que foi construído a partir do tratamento do extenso produto conseguido, buscando sentido e forma, processo que terá sua completude no próximo capítulo, quando os resultados do presente serão confrontados com o marco teórico freireano e a literatura relacionada, como já exposto na capítulo anterior.

A confecção do presente firmou-se pelo uso de três dimensões da problemática, com vistas à apreensão da construção resultante entre o modelo pedagógico dos cursos investigados e o cursar do mesmo pelos acadêmicos investigados. Para apreensão da dimensão coletiva utilizou-se grupo focal, conforme discutido no capítulo anterior. As entrevistas individuais semi-estruturadas objetivaram a perspectiva individual sobre os temas, enquanto que a análise documental das matrizes curriculares cada um dos cursos foi realizada orientada ao 
entendimento da estrutura e conteúdo oficial do processo ensino-aprendizagem a que estes acadêmicos foram submetidos durante sua graduação.

\subsection{A perspectiva dos acadêmicos de Enfermagem}

\subsubsection{O produto do Grupo focal dos acadêmicos de Enfermagem}

\subsubsection{Núcleo Temático 1: Sobre o modelo pedagógico no ensino de Enfermagem}

Com relação ao modelo pedagógico implicado na formação destes acadêmicos de Enfermagem, ficou registrada a presença verticalidade na relação aluno-professor em alguns momentos importantes do processo ensino-aprendizagem, como nos estágios supervisionados, o que foi apontado pelo grupo como uma relação desgastante.

\footnotetext{
Tem professores que ficavam no estágio apenas como supervisor, só olhando o que você está fazendo e depois fica criticando na hora do procedimento. Para esse a gente nunca faz o melhor que a gente pode. Esse sempre está ali jogando pedra o tempo todo.

Então você sente o que? Incapaz de fazer aquilo.

Tem professores nos colocam como um ser inferior a eles.

A gente teve uma única professora que nos falou sobre o mestrado porque fomos procurar por ela. Ela ficou superfeliz. O resto dos professores desconversam quando a gente toca no assunto de mestrado. Como se não quisessem que a gente fizesse.
}

Em contraponto a esta postura verticalizada de alguns professores, as discentes defendem que, para sua formação, a autonomia do aluno é fundamental em seu entendimento, no sentindo do aprender fazendo. A questão da avaliação e da atribuição de notas para a atuação das alunas no estágio se mostrou como um 
instrumento silenciador no processo, que conta com a fragmentação dos temas em disciplinas e a dissociação em dois momentos: entre teoria e prática. Todas características tipicamente da educação 'bancária', no universo conceitual freireano ${ }^{35,36}$

Você só sabe o que é Enfermagem a partir do momento que você vai para prática. Só quando você tem uma experiência de estágio, em que você não tem um professor, como é o caso do estágio remunerado extracurricular, é que você percebe realmente a profissão de ser enfermeiro. Antes da faculdade eu pensava que fazia quase mesma coisa que Medicina. E é totalmente diferente.

Quando estamos no campo do estágio e o professor está junto nós nos comportamos de um jeito, sendo acadêmico, ele está lá formando a gente. Mas quando nós estamos fora, no estágio extracurricular do hospital universitário é totalmente diferente: com o professor nós agimos de determinada forma, temos determinado comportamento. É como se fossemos menores. Quando estamos sem o nosso professor a gente cresce, aparece, temos autonomia para tomar decisão. A equipe do hospital nos respeita, nos vê como enfermeiros-acadêmicos. Mas com o professor, com intuito do seu trabalho, é diferente. Ele nos trata como alunos e não como futuros enfermeiros. O professor foca a matéria em questão e nós somos alunos. Nós não temos autonomia. Ele nos vê como alunos que estão ali para obedecer ordens deles.

Você não tem autonomia quando você esta com o professor.

Você vê o problema, acontece uma coisa e você não tem decisão de nada. Tudo você tem que levar para o professor porque ele é quem vai decidir.

Eu nunca disse nada por que professor vai me avaliar, me dar nota. Ele vai me dar nota não posso discutir se está errado, porque ele vai me dar nota. Isso tem um peso e você não pode mudar isso.

É importante que o professor esteja ali do lado, mas acho que o professor tem que deixar o aluno procurar onde ele tem dificuldade e ir aperfeiçoando essa parte.

No Estágio Curricular 1 e 2 era para gente caminhar, ter autonomia de fazer algumas coisas, mas o professor nos acompanha como acompanhou nas disciplinas. 
Pelo nosso Currículo, nós temos a maioria das disciplinas separadas, não integradas. Só nesse ultimo ano é que nós tivemos Estágio Curricular 1 e 2, nos quais a gente volta para essas matérias. É como se só fosse aula prática.

Paralelamente, estas acadêmicas apontaram para a perspectiva de que a relação horizontal entre o docente e o discente é uma postura importante, inclusive nas deficiências que o discente apresenta quando confrontado com a prática. Também que a dissociação entre teoria e prática não permite que o acadêmico estabeleça as relações necessárias da primeira aplicada a última, o que se traduz em prejuízo à sua formação, mesmo nas disciplinas que têm por finalidade humanizar o futuro profissional de saúde.

Tem estágios que o professor realmente fazia junto coma gente. Esse se igualava com a gente. Fazia o mesmo trabalho que a gente, enquanto os outros não.

Tenho uma amiga que não conseguiu o estágio extracurricular. Eu não sei se ela teve alguma deficiência durante a graduação. Quando ela ficou em uma enfermaria que só tinha paciente grave, já no primeiro dia, aquilo foi um impacto para ela. Mas a professora, sentindo a insegurança dela, ficou do seu lado o tempo todo. Tudo ela se apavorou até para colocar um soro. Ela não conseguia. Então ela chegou chorando e disse 'gente eu não sei como cheguei aqui... eu não sei', então o que a professora falou para ela 'agora não é hora de chorar... agora é hora de ficar calma e fazer. Se não aprendeu, vai aprender agora'.

$\mathrm{Na}$ nossa grade temos a psicologia, a filosofia e temos a antropologia. Às vezes eu não sabia o porquê dessas matérias... Os professores também iam bem distante do real. A gente vai entender a importância quando está na prática, quando a gente está com paciente. Agora sim entendo porque tinha essas matérias, porque tinha psicologia, tem duas psicologias: geral e educação. Tudo isso nos ajudou muito. 
s características aqui apresentadas no processo ensino-aprendizagem de Enfermagem denunciam $o$ talhe tradicional $\mathrm{e}$ incoerente com enfoque no desenvolvimento de postura crítico reflexiva nos futuros enfermeiros, segundo a perspectiva freireana, incorrendo na desumanização da relação docente-discente, o que pode refletir-se na postura destas futuras enfermeiras ${ }^{35,36,79-88}$.

\subsubsection{Núcleo Temático 2: Sobre o ser enfermeiro}

Na medida em que a motivação para ingressar em um curso universitário está sobremaneira implicada no perfil dos acadêmicos que nele ingressam, foram investigados os motivos que levaram estes acadêmicos a cursar Enfermagem.

O fato de o curso estar vinculado a uma instituição pública federal foi apontado como fator importante para opção pelo curso.

Enfermagem foi a ultima coisa dentro da área de saúde. Marquei no vestibular por ser federal, deixei de cursar psicologia que era particular.

O mercado de trabalho do enfermeiro na época do ingresso no curso foi outra motivação.

Na época que prestei vestibular era uma profissão muito boa, muito gratificante. $\mathrm{O}$ enfermeiro ganhava muito bem. 
A influência de familiares próximos emergiu como outro fator na definição da carreira.

Eu convivia com minha mãe e meu pai, que são da área da saúde. Isso já foi crescendo comigo. Terminando o ensino médio fiz curso de técnico em Enfermagem e gostei.

Também a questão da carreira ser da área de saúde e do trabalho no setor da saúde emergiu.

Eu já cursava serviço social. Sempre gostei muito da área de saúde, cuidar da doença. Não consegui passar em Medicina, comecei serviço social e achei que não era o que eu queria.

Identifico com a Enfermagem, me identifico com o clima hospitalar, aquele ambiente do hospital.

A principal motivação para a escolha do curso, paralelamente as demais motivações e imbricada com as mesmas, como pôde ser percebido, foi o relacionamento entre a futura profissão e o cuidar, ato intimamente relacionado ao procedimento de Enfermagem no olhar deste grupo de acadêmicos.

O meu foco é trabalhar com pessoas. Então conversei com meus pais e resolvi por Enfermagem e até hoje não me arrependo. Eu me encontrei.

Gosto de cuidar, por isso Enfermagem.

Escolhi pelo cuidar também, ter a possibilidade de ajudar as pessoas e ganhar para isso.

Me identifico com a equipe, gosto de lidar com o paciente. 
Um achado muito reincidente foi esta relação entre a Enfermagem e o cuidado, não apenas no que se refere a opção pelo curso, mas como atividade diuturna na vida profissional do enfermeiro. Um cuidado tomado como indistinto e a todos que necessitem, inclusive pela importância deste cuidado na vida das pessoas. Acreditam que a atuação não se limita a atuação frente à doença e a cura-reabilitação.

Quando a gente faz um trabalho que a gente vê que o paciente ficou feliz por aquele cuidado que, a gente promoveu um cuidado diferencial com aquele paciente, a gente percebe que realmente faz um bem a uma pessoa, deixando alguém feliz. Não posso fazer para todo mundo, mas pelo menos aquele que estou fazendo estou fazendo com qualidade.

Ser enfermeiro está muito ligado com a palavra cuidar. Ser enfermeiro é ser um cuidador que está pronto para cuidar de qualquer situação que apareça.

Enfermagem é a arte de cuidar. A gente tem que estar pronto para cuidar do paciente, do atendimento básico até a mais alta complexidade.

Como enfermeiro, você tem que estar preparado para cuidar independente de raça, independente de tudo. Você deve cuidar de um paciente indigente da mesma forma que do governador.

O enfermeiro deve cuidar as vezes do bandido e do mocinho. No hospital, por exemplo, chega o que tomou a facada e o que deu a facada. O policial e o bandido. E o enfermeiro tem que ter o mesmo comportamento, que ser imparcial.

As vezes você sabe que aquele paciente é um bandido, um traficante, mas você tem que cuidar, porque é um ser humano que está ali. O atendimento não tem nada a ver com o que ele fez lá fora. Neste momento todos são iguais.

A Enfermagem é isso: cuidar independente de raça, sem ter diferença.

É importante falar também que ele cuida não só da parte física mas também da parte emocional, da parte psíquica agente é responsável por tudo, esse é o enfermeiro da Enfermagem também, porque você as vezes a gente esta lá e nem toda hora tem um psicólogo. 
Fomos preparados na academia para isso: cuidar do outro, doar nossa vida.

O enfermeiro cuida do próprio paciente e dos familiares dele.

Se a mulher entrou na sala de parto, se ela teve 10 filhos... não me interessa se ela teve 10 filhos, mas 'como a senhora está aqui, a senhora tem 10 filhos e a senhora está chorando de dor?' Esse julgamento não cabe a nós. $O$ julgamento compete a ninguém.

O enfermeiro lida na prevenção, na recuperação. Trabalha antes da pessoa ficar doente, quando a pessoa esta doente e no ambulatório.

O enfermeiro atua em todos os estágios da saúde e do doente.

O enfermeiro é um profissional de saúde porque lida diretamente com a vida de outro ser humano.

A Enfermagem não é voltada só para doença.

Ser um profissional da saúde para mim é participar de todo campo que envolve a saúde.

A atuação do enfermeiro não é voltada só para a doença. Também lida com o problema psicológico do paciente, o problema físico, o problema familiar. A gente entra nesse meio todo.

Não é só tratando da doença. Na Enfermagem, você faz saúde tratando bem aquele ser humano, trabalhando naquele momento que ele está triste.

Você faz saúde juntando tudo: prevenindo, educando, promovendo e reabilitando o paciente. Se você fizer todas essas coisas você está promovendo saúde.

Para estas acadêmicas, pelas características do trabalho de Enfermagem, o exercício profissional do enfermeiro está relacionado ao doar-se.

Ser enfermeiro é uma doação que nós fazemos da própria vida. Passamos mais tempo dentro do hospital do que com a nossa família. Você faz parte de todo aquele complexo [sistema de saúde] e sabe o que o paciente tem e o que ele precisa. 
Diversas perspectivas sobre humanização foram firmadas pelo grupo de acadêmicas. A categoria mais reincidente foi à humanização significando se colocar no lugar do outro quando do atendimento, inclusive sendo aludido que esta é uma perspectiva trabalhada durante a graduação. Na mesma categoria, foram inseridas as falas sobre o tratar do paciente como um ente querido para estas acadêmicas.

A gente trabalha muito isso na academia, essa questão de se colocar no lugar do outro.

É... tem que se colocar no lugar do outro.

Você tem que se colocar no lugar da pessoa que está em sua frente, que pode ser um paciente seu, pode ser uma pessoa bem próxima a você, que você pode perder por não dar o seu cuidado.

Humanização é se colocar no lugar do outro, pensar que aquele ali poderia ser meu pai, minha mãe.

Porque eu vou fazer o melhor? Porque eu vou fazer por alguém. Por mim mesmo não vou fazer. Vou fazer por que aquela pessoa poderia ser meu pai, a pessoa que eu mais amo na vida.

Outra perspectiva foi humanização tendo como significado o respeito aos componentes do paciente, como um ser humano complexo.

Eu acho que a atuação deve ser a mais humanizada possível. Respeitando acima de tudo que é um ser humano. Tratando ele como ser humano e respeitando seus limites.

Também a humanização foi evocada como um conceito intimamente e essencialmente relacionado à prática de Enfermagem. 
Você pode prejudicar o paciente por falta de compromisso, por falta de humanização, falta de responsabilidade. Até mesmo com a falta de respeito.

O reconhecimento do paciente como ser humano e a visão do ato de Enfermagem como um ato para o benefício do ser humano sintetiza a visão destes acadêmicos sobre a questão, uma vez que Enfermagem foi aludida como a arte do cuidar de seres humanos, o que encontra coerência com o marco teórico freireano, apesar de que os aspectos apresentados referem-se a uma das interfaces da questão da humanização neste universo conceitual, haja vista para que humanizar em sentido freireano é muito mais do que tratar bem, como discorrido anteriormente $\mathrm{e}^{35,36,79-88}$.

\subsubsection{Núcleo Temático 3: Sobre a relação Enfermeiro-Paciente}

No que se refere a percepção da felicidade do paciente e a utilização dos serviços de atenção a saúde, a hospitalização foi apresentada como prejudicial as pessoas, na medida em que o viver da pessoa no ambiente hospitalar diverge e difere de seu viver em sua residência, não apenas pela estrutura física do local, mas também pelos hábitos, padrões de comportamento e experiências. A importância de uma atuação humanizada do profissional de saúde neste momento da vida dos pacientes foi ressaltada como de fundamental importância, na medida em que grande parte do que foi apresentado indica que, por estar em um contexto que difere de sua vida diária, o paciente apresenta-se sensível e necessitando de proximidade, na maioria das vezes estando distante de seus familiares e amigos. Todas estas questões estão 
implicadas na percepção de dor dos pacientes, não apenas na dor física, mas principalmente a dor emocional que, segundo estas acadêmicas, deve ser uma linha de atuação dos profissionais de saúde.

A gente faz o possível para aquela pessoa fique naquele ambiente [o hospital] mais confortável possível. A gente trata a parte mental. É muito constrangedor você ver uma pessoa ali e não saber nada. $O$ ambiente muda tudo. $\mathrm{O}$ ambiente hospitalar deixa a pessoa triste. Cabe ao profissional chegar naquele momento e tentar modificar a situação. É por isso que a gente fala que a gente também trabalha a parte psíquica.

Porque nessa hora [de hospitalização] é igual pra todo mundo. É igual pra quem vai pra particular, é ruim de estar sozinho nessa hora.

O paciente quando está no hospital está em um momento que esta mais vulnerável, mais fragilizado. Você se põe no lugar do paciente. Isso é maravilhoso.

Eu nem gosto muito da nomenclatura cliente. Acho que foge a nossa área, cliente é o que procura o advogado que sei lá, o que, mas para área da saúde acho que não cabe. Para mim eu penso que o paciente ele é um ser humano como eu, que tem uma vida como a gente, que tem parente, que tem a casa dele, que tem a forma de dormir, os hábitos, que entra no hospital e ali muda tudo para ele. A gente tem que saber ver todo esse lado porque no hospital ele está numa outra posição, que ele não queria estar. Ninguém quer estar hospitalizado. Tudo muda para ele da noite para o dia. Ele está fragilizado, esta triste, ele não queria aquela situação.

No hospital o paciente está sentindo dor, está separado da família. A gente não. A gente entra no hospital, desenvolve o trabalho e a noite vai para pizzaria e na sorveteria, fica de férias. Ele não. Ele está ali com aquela doença.

A atuação do enfermeiro na comunidade foi destacada como uma importante frente para a consecução do 'ser enfermeiro', sendo que emergiram duas representações: a importância da presença do enfermeiro na vida do paciente, tanto 
quanto, em outra mão, a importância da saúde da comunidade como indicativo da atuação do enfermeiro.

Quando a gente chega na casa de um paciente é que percebemos que a gente tem uma função importante. 'Chegou o enfermeiro' eles dizem. Eles valorizam muito... 'ela veio cuidar de mim'. É aí que você vê o papel que você desenvolve naquela comunidade.

A comunidade é o espelho do enfermeiro. Se a saúde daquela comunidade estiver bem é porque o enfermeiro faz o trabalho adequado.

Nesta mesma abordagem sobre a existência de certa implicação complexa entre vida e saúde, as condições sociais do paciente foram aludidas como parte integrante e moduladora da saúde das comunidades, de forma que o enfermeiro deve direcionar sua intervenção no contexto vivido pelo paciente, segundo este grupo de acadêmicas.

Existem certas doenças que o paciente precisa ter alimentação em especial. 0 paciente tem a moradia totalmente precária, come hoje e não sabe se vai comer amanhã. Como ele vai comprar um remédio para gripe do filho se ele não tem roupa não tem comida entende?

As vezes a gente indica que o paciente tem que fazer um suco de laranja com beterraba. Devo, antes de eu falar, procurar qual é a fruta que o paciente tem.

Também nesta visão complexa para a atenção em saúde, foi reincidente a visão de que é importante o diálogo com o paciente, como parte do atendimento de Enfermagem. 
As vezes você para ao lado de um paciente e ouve toda a história da vida dele, simplesmente porque ele está sem acompanhante e não tem ninguém para conversar. Esta é até uma forma de tratar. Se você passar 30 minutos conversando você o tratou. Ele se sente melhor. Vai almoçar melhor, vai jantar naquele dia.

O respeito ao paciente e sua implicação no acolhimento emergiu como uma perspectiva importante na atuação do pessoal de Enfermagem para estas acadêmicas. Bom trato, aceitar a cultura do paciente e satisfação pessoal do enfermeiro foram características relacionadas para este grupo.

Se você for um bom enfermeiro, se você trata bem o seu paciente, de uma forma boa e adequada, quando você termina aquele plantão você sai feliz. Daí, quando você volta o paciente esta lá e te recebe bem: 'ah! Que bom que você chegou. Que bom que você vai estar aqui comigo'. Isso é muito gratificante! Você vê que ele melhora com a sua presença.

Hoje passamos por uma situação interessante: o paciente chegou na unidade de saúde com uma folha no pé, colocou uma mistura de mandioca que ele bateu, colocou no pé. Quando eu olhei, a gente que trabalha na clinica cirúrgica com todas as técnicas assépticas. Minha vontade é pegar aquilo ali, tirar essa folha, lavar. Pegar uma bacia, lavar mesmo e fazer um curativo.

Você deve respeitar a escolha do paciente mas também pode ir adequando, paralelamente. No caso do senhor que a comentou, a gente poderia instruir 'você pode colocar a folhinha, mas também pode fazer o curativo', Como isso eu não mandei ele tirar a folhinha dali, mas também o instruí a fazer o nosso procedimento certo. A gente tem que adequar, não tirar totalmente a crença dele. A mesma coisa é respeitar um indígena que chega no hospital. Ele não come alguns tipos de comida, então eu vou lá com a nutricionista converso com ela, observando se vai fazer mal ou não para ele. $A$ gente tem que ter discernimento e tentar adequar as coisas.

Esta perspectiva de horizontalidade para a atuação do enfermeiro junto ao paciente direcionou os diálogos para a importância da Educação para Saúde como 
parte da atividade da Enfermagem, sendo, até mesmo, relatada a existência da disciplina "Educação e Saúde" como instrumento na formação destas acadêmicas de Enfermagem.

Tivemos até uma matéria 'Educação e Saúde' que é pra nos ensinar como conversar com a comunidade tirando os termos técnicos, falando a linguagem da população, respeitando a população, as crenças e tudo mais.

Além de trabalhar na promoção e prevenção a gente também trabalha com a educação. A educação dos nossos funcionários e a educação da população também, porque quando você discute um tema você está educando, você está somando.

Tem várias formas de se trabalhar com a comunidade. Até mesmo no hospital dá pra se fazer educação com aquele paciente. Aquele paciente é de uma determinada comunidade. Nós que somos futuros profissionais e podemos trabalhar na nossa igreja, naquela comunidade, estar educando de estar informando. Dá para trabalhar muito bem com educação em saúde, independente do campo de atuação na Enfermagem.

A gente está promovendo saúde através da educação, através da prevenção, das orientações que são feitas no dia a dia do hospital, no posto de saúde.

O paciente foi apresentado por estas acadêmicas como a pessoa que depende da atuação dos enfermeiros no momento da doença. A possibilidade de atuação do profissional de saúde foi aludida como ampla, nas diversas dimensões da vivência da doença pelo paciente, tanto quanto não importa a categoria profissional a que se pertença, mas sim que o profissional atue na necessidade dos pacientes.

O paciente é aquela pessoa que está ali para ser cuidada pela gente em todos os sentidos. 
Eu vejo o paciente como uma pessoa assim totalmente fragilizada, inteiramente fragilizado e dependente.

Não interessa se é função do técnico ou do auxiliar. As vezes você vê que aquela pessoa está precisando de algo e não tem ninguém disponível para fazer. Porque não fazer? Só por que somos enfermeiras?

A questão das dimensões da dor dos pacientes mostrou-se importante para estas acadêmicas. Estas dimensões tangenciaram não apenas a dor física, mas também a dor emocional, inclusive sendo referido que o profissional de saúde é um indutor das dores emocionais por diversos silêncios e ausências durante a atenção. E que a atuação do profissional pode modificar esta dor.

O paciente sente dor ou pela patologia, e associado a dor de patologia, ele pode sentir dor por varias outras coisas porque está sendo maltratado, está abandonado.

Muitas vezes o enfermeiro compartilha da dor do paciente, o filho que perde o pai, a esposa que perde o marido, fica chorando aquela dor.

É muito difícil lidar com a dor do outro.

Não existe uma matéria pra a gente aprender lidar com a dor. São coisas que agente aprende no dia a dia. Em relação em ser mais fria, não se envolver, isso não existe. $O$ que acontece é a gente conseguir sentir a dor não com a mesma intensidade.

A dor física a gente tem como lidar através do medicamento que o medico prescreve. As vezes o paciente está se queixando de alguma coisa e não tem medicamento para isso. Tenta procura o médico da urgência para tentar resolver e é a dor emocional. Temos que tentar conversar, amenizar os problemas, tentando dizer para ele que é uma situação momentânea, que tudo vai melhorar.

Ele [o paciente] sente dor por também estar trazendo dor para família. As vezes ele fica muito triste, sentindo uma dor interna por estar vendo todo o sofrimento que a família esta tendo para 
acompanhá-lo no hospital, para fazer o revezamento. Acompanhar é uma dor também, que você sente.

O paciente que não tem acompanhamento da família muitas vezes cria situação de dor para que o profissional chegue até ele. Basta você chegar e conversar e quando você voltar já passou. É aquela dor da alma mesmo, do local do corte, da lesão.

Por falta da família o paciente chama a gente para conversar, porque todo hospital tem sua regra. As vezes é uma mãe que está sentindo a dor de não estar perto da filha.

Nesta questão da atuação do profissional de saúde e de suas deficiências frente ao atendimento ideal no trato ao paciente, foi apresentado que a estrutura do sistema de saúde desumaniza, na medida em que existe uma demanda muito maior que a capacidade dos profissionais vinculados, o que se traduz em sobrecarga de trabalho para estes e por suas atuações enfocadas no retorno financeiro.

Na pratica não é todo dia que se tem uma postura humanizada. Em alguns momentos isso me escapa. Mas porque escapa? Porque eu também sou humana. Porque eu também tenho falhas..

A sobrecarga de trabalho é bem responsável pelo atendimento desumanizado. $O$ governo não paga adequado. Por isso que tem muitos enfermeiros se matando de trabalhar, tem muito nutricionista se matando de trabalhar, muitos médicos se matando de trabalhar.

0 estresse faz com que os profissionais tratem mal os pacientes. 0 paciente chega e há aquela correria, tão grande que a pessoa não quer esperar. Ela quer ser atendida, não interessa o que está acontecendo ali dentro. Esse estresse todo entre paciente e profissional também causado pela situação faz com que o atendimento seja de má qualidade.

O país está atravessando uma fase tão crítica na saúde, que até o serviço particular está ruim. $\mathrm{O}$ descaso é geral.

E agente vê que muitas vezes o paciente não é respeitado como o tal. Fica parecendo que ele tem que ser uma pessoa passiva, que 
tem que aceitar tudo o que as pessoa querem fazer com ele. Mas ele é um ser humano e tem que se respeitar as vontades, as atitudes dele.

$\mathrm{Na}$ realidade as vezes não vejo compromisso dos profissionais de saúde com a humanização. Não vejo responsabilidade muitas vezes. Eu vejo muito descaso. Isso entristece, decepciona. Isso faz a gente pensar se realmente vale a pena. È muito difícil alguém se dedicar estudar tanto e no momento de agir não fazer de forma correta. Se fosse um parente meu hospitalizado e viesse, por exemplo, com uma alteração no exame dele, ai o médico olha sai e fala 'deixa para o próximo plantão'. Não estou falando da psicologia, Medicina, nutrição. Estou falando do geral. Existem os bons e os não tão bons. Mas isso é grave. A partir do momento que eu dispor a trabalhar para o outro, com a vida do outro, sou responsável pela vida dele. Se ele vai morrer ou se ele vai sobreviver, se aquilo depende parte de mim, eu acho que isso muito grave.

Os profissionais de saúde estão mais preocupados com quanto estão ganhando naquele momento para fazer aquele plantão 12 horas 24 horas do que com o atendimento.

A maioria dos profissionais de saúde querem simplesmente fazer. Não fazem com qualidade. Fazem por fazer.

Fica patente o entendimento da complexidade da vida do paciente e da importância de aspectos psicossociais na saúde. No entanto, reincide o silêncio de como operacionalizar na prática cotidiana de Enfermagem estes conceitos, denunciando tanto para a desarticulação entre teoria e prática no ensino de Enfermagem, como para o enfoque no ensino técnico e não humanizador neste curso, conforme o universo conceitual freireano $35,36,79-88$. 


\subsubsection{Núcleo Temático 4: Sobre o Enfermeiro e o trabalho no Serviço de Saúde}

O tempo que o paciente fica junto aos enfermeiros e equipe de Enfermagem foi apresentado como um componente de humanização e que diferencia a atuação destes profissionais da dos demais profissionais da saúde, tais como os fisioterapeutas e os médicos. Para estes acadêmicos, este maior tempo de contato significa maior proximidade do paciente e um atendimento diferenciado no sentido do acolhimento. Em decorrência, o Enfermeiro apresenta perspectiva mais ampla da saúde dos pacientes que os demais profissionais, segundo a visão destes acadêmicos.

Quem fica acompanhando os pacientes somos nós, as enfermeiras, 12 horas, 24 horas por dia. Tem momentos que o paciente chora, que está com raiva. Cabe a gente chegar e conversar para melhorar o humor do paciente, seja de raiva, tristeza, estresse.

O enfermeiro é a pessoa mais próxima do paciente. 0 enfermeiro tem uma visão melhor que o técnico, muitas vezes melhor que o médico, porque o médico fica 10 minutos frente ao paciente e você fica o dia todo.

Se as outras profissões fossem voltadas mais para a parte da humanização o serviço iria melhorar.

O fisioterapeuta tem um compromisso: ele vai naquele horário, faz o trabalho dele e depois vai embora. O médico está ali ganhando plantão mas não está nem aí com o paciente. Quantas vezes a gente vai lá, chama o médico e ele pergunta 'é grave. Porque se não for eu não vou'. Se estou chamando é porque o paciente está precisando não é verdade? Eu não estou lá pra brincar. Acontece muito descaso.

As vezes o médico não fica sabendo do problema nutricional, do problema psicológico, mas o enfermeiro sabe de tudo. Tem que saber toda história, o diagnóstico, as cirurgias, porque fez porque não fez. 
A percepção do enfermeiro como líder da equipe de saúde, principalmente no ambiente hospitalar também emergiu nas falas, sendo muito referida a questão de que a técnica não é a principal dimensão da atuação do enfermeiro e que é justamente ai que se diferencia o enfermeiro do profissional técnico e auxiliar na equipe.

O Enfermeiro para mim é o coração do hospital e da clínica. Ele interage em todas as áreas, interage com funcionários, faz os cuidados básicos, a comunicação com a equipe médica, a comunicação com o paciente. Todo e qualquer problema passa pelo enfermeiro.

O trabalho da equipe depende muito do enfermeiro. Depende dele ser unido e comandar sua equipe, porque se ele não comandar fica tudo bagunçado e então não vai haver trabalho em equipe. Cada qual vai querer fazer o trabalho, não um bom trabalho.

O enfermeiro é um profissional de saúde no sentido de comandar a equipe, comandar a clínica, estabelecer uma postura, saber por que você está lá.

O enfermeiro é tudo. Se ele falta só um dia em um hospital não sei o que seria.. porque ele que articula todas as coisas. Ele é o coração da saúde.

A gente foi muito preparado nesse sentido, de diferenciar bem: existe o técnico de Enfermagem e ele é profissional para desenvolver técnicas. O enfermeiro não é só técnico. Ele é preparado para desenvolver as técnicas, mas ele tem que saber o porque. Ele tem que ter o conhecimento científico de todas as ações. Você não é técnico. Você é enfermeiro.

Até nas provas quando tirávamos nota baixa o professor dizia: 'vocês vão ser enfermeiros, tem que saber'. No nosso dia a dia a gente para pra pensar "É eu tenho que estudar mais porque vou ser enfermeiro, não um técnico".

Paralelamente a estas considerações quanto ao papel e a importância da

Enfermagem na equipe de saúde, reincidiu o entendimento de uma certa baixa 
valorização da Enfermagem frente aos demais profissionais, algo incômodo para estas acadêmicas.

Mesmo antes de ingressar eu via a Enfermagem como uma profissão que não é valorizada quanto outras profissões. Hoje ainda penso assim porque vejo que nós trabalhamos tanto, passamos mais tempo fora de casa do que em casa.

Geralmente o médico não aceita a importância do enfermeiro. Tem essa briga, tem essas coisas de o médico estar sobre o enfermeiro. Acho que agora o enfermeiro está querendo o seu lugar. 0 enfermeiro está procurando mais o seu espaço, não está deixando as pessoas invadirem e se intrometer no que ele faz. Acho que agora nós estamos tendo uma visão melhor do que é ser enfermeiro.

Uma importante perspectiva referente a baixa valorização do enfermeiro emergiu na referência a existência de disputas por espaço e conflitos entre os médicos e os enfermeiros

Eu lembro que uma vez uma professora falou, uma vez assim para mim "você sabe que o paciente precisa de tal coisa, mas o medico não viu. Ele acha que não. Você não pode chegar lá com ele e dizer: 'o paciente precisa disso por causa disso'. Você tem que chegar e sugerir para ele.

O médico tem a função dele e não vou também chegar lá e fazer a função dele. Não é a questão de ser limitada. Acho que a Enfermagem não é limitada. Está ali para fazer o papel dela. Se eu vejo que tem um problema passo para o medico. Se o medico não quer tomar aquela decisão paciência. Fui no meu limite aonde eu posso ir.

Uma dor que eu acho que a equipe de saúde é bem responsável é a dor de não saber o porque da doença, não saber como e o que vai acontecer.

Alguns profissionais preferem não dizer algumas coisas para o paciente. Claro que tem jeito para tudo. Tem jeito de falar qualquer coisa, mas tem pessoas que preferem optar porque não falar nada 
pensa 'o paciente não tem que saber... eu sou a enfermeira, eu sou o medico, então eu sei que é assim o melhor para o senhor'. Aquilo traz insegurança para ele, e ele sofre por isso.

Outra informação que emergiu é a questão de que, as dificuldades do trabalho em equipe de saúde não são apenas relacionadas ao tipo de trabalho, mas também à questão de que, como seres humanos, os trabalhadores de saúde apresentam-se com suas características pessoais facilitadoras e outras que dificultam os bons relacionamentos entre os componentes da equipe.

Eu acho que em algumas instituições é complicado trabalhar, porque trabalhar com o ser humano é difícil. Dependendo do ambiente você tem aquele contato maior entre os profissionais. Você consegue atingir, trabalhar em equipe, tanto enfermeiros, técnicos, toda a equipe de Enfermagem, quanto a equipe de saúde dentro do hospital, depende da equipe e das pessoas.

Do apresentado, houve certo silêncio com relação a dimensões do trabalho do enfermeiro em equipe de saúde no PSF, e do impacto, tanto quanto da necessidade, de um agir intersetorial colocando-se como ator e agente de mudanças para estas acadêmicas. Faz-se mister refletir a implicação destes silêncio com um modelo pedagógico que pode ser caracterizado como orientado a perspectiva bancária e tecnicista ${ }^{35,36,79-88}$. 


\subsubsection{0 produto das entrevistas individuais de acadêmicos de Enfermagem}

\subsubsection{Primeira Categoria: A universidade}

Nestas entrevistas individuais, a estrutura do curso de Enfermagem foi apresentada como importante para a formação dos futuros enfermeiros, principalmente legando a base teórica para a atuação profissional, restando lacunas quanto a questão da abordagem da prática, principalmente no que se refere a articulação do ensino com a realidade que as futuras enfermeiras se depararão no diaa-dia do processo de trabalho em Enfermagem.

Não acho que a universidade ensina tudo. Tudo não. A gente vai aprender no dia-a-dia essa pratica. O principal foi passado e deu para adquirir as habilidades técnicas.

(AEnf 01)

Em algumas matérias faltou o professor aprofundar um pouco o conteúdo.

(AEnf 04)

Tem muito professor que não conhece nada da realidade.

(AEnf 05)

A acho a metodologia de alguns professores muito antiga, jogar as coisas assim mais para a realidade porque o nosso nível é muito americanisado. Quando agente estuda é 'nos Estados Unidos não sei o que'. Realmente falta mostrar a realidade para gente, como é no Brasil, no Estado, na capital.

(AEnf 02)

Tem que mudar a metodologia de alguns professores e trabalhar mais a nossa realidade.

(AEnf 04)

Estas questões tagem indiretamente na questão da segurança para a prática de Enfermagem posterior a graduação. As acadêmicas revelam que há certa insegurança 
para a prática na construção educacional referente a estrutura oficial do curso de Enfermagem. Como forma de resistência a este processo, algumas acadêmicas participaram de estágio extracurricular no hospital universitário que, segunda as entrevistadas, garantiu um maior conhecimento sobre a prática. Este desenvolvimento foi permitido graças a relativa autonomia que as estagiárias possuem nas atividades do estágio clínico o que, segundo as mesmas, diverge do modelo pedagógico utilizado na estrutura curricular de Enfermagem.

Às vezes eu me sinto que eu vou sair da faculdade e não sei nada. Em relação a graduação acho que a gente só aprende mesmo na pratica, no mercado de trabalho, não aprende tudo, não consegue chegar a $100 \%$.

(AEnf 02)

Me sinto preparada tecnicamente para atuar como enfermeira, mas principalmente pelo estágio.

(AEnf 01)

Não me sinto $100 \%$ preparada, mas assim uns $80 \%$, $85 \%$ eu me sinto, pelo fato de eu ser bolsita no Hospital Universitário e fazer estágio extra-curricular. Mas se fosse só pela graduação, só pelas oportunidades de estágio não estaria. Acho que pela universidade agente está totalmente despreparada.

(AEnf 03)

A nível de técnica me acho preparada. A graduação te dá o caminho mas foi muito devido ao estágio extra-curricular remunerado que a gente conseguiu mão para atuar como enfermeiro. Na faculdade você aprende técnicas e conhecimento científico, mas se for só por isso você sai muito deficiente.

(AEnf 04)

Antes eu pensava: 'como é que eu vou fazer. Eu não me vejo formada. Acho que eu vou sair formada e não sei nada'. Quando eu entrei no estágio extra-curricular fui aprendendo tanto. Quando a gente chega não sabe nada. $O$ enfermeiro responsábel pega na tua mão e te ensina na prática. E é incrivel. Em um ano você já está livr, já te deixam cuidar das coisas como enfermeira. Não se preocupa contigo. Se ele precisa sair deixa a clínica na tua mão, que ele sabe 
que tu é capaz. A cada dia aparece situações que você se sente impotente porque assim a Enfermagem é. Você trabalha com educação, você trabalha com prevenção nas unidades básicas, com consultas, trabalha no hospital com assistência e dentro do hospital. E vai aprendendo conforme vai fazendo.

(AEnf 03)

Acho que a convivência dentro do hospital é que de verdade foi me moldando como profissional, mas a faculdade prepara bem apesar de que as vezes é muito curtinho o tempo que a gente passa na clinica.

(AEnf 03)

A questão da distância do modelo pedagógico empregado no ensino de Enfermagem da realidade, não se limita à deficiência na articulação com atividades práticas, mas também na problematização da realidade clínica, na medida em que as práticas de ensino simulam apenas os aspectos da técnica de Enfermagem, não refletindo os demais fatores do entorno do atendimento, tais como a realidade brasileira ou mesmo o número de atendimentos que o futuro enfermeiro se deparará no seu dia-a-dia.

Para ser um bom enfermeiro tem que ser muito bom na parte administrativa e muito bem na parte assistencial. Nós somos muito cobrados na parte administrativa. $O$ professor quer que agente saiba fazer uma escala e tudo mais, agora na parte assistencial deixa um pouco a desejar pelo fato de nem sempre ter possibilidade de fazer os procedimentos.

(AEnf 02)

Se livro diz que para o enfermeiro fazer uma assistência sistematizada tem que estar com pelo menos de 5 a 10 pacientes, 0 que a gente vê na prática é que ele estará com 40 pacientes. É impossível fazer o diagnostico de todos os pacientes. $O$ enfermeiro se mata de tanto trabalhar. Isso deveria ser passado de forma mais real.

(AEnf 03)

Na graduação, quando a gente está estudando o professor pede para gente ficar com um único paciente e aí a gente consegue fazer o histórico todinho daquele paciente, fazer os diagnósticos e as prescrições. Mas os professores deviam abrir mais os nossos, olhos para nós nos preparamos a fazer com todos pacientes que a gente vai 
ter, essa seria uma forma de melhorar, porque ficou um pouco distante, fora do real.

(AEnf 04)

Fica patente a implicação do modelo pedagógico na perspectiva de atuação destas futuras enfermeiras ${ }^{35,36,79-88}$.

\subsubsection{Segunda Categoria: O professor no ensino de Enfermagem}

Para estas acadêmicas de Enfermagem, no corpo docente de seu curso existiram muitos professores com características da educação bancária. Entre as características, as que mais se mostraram proeminentes foram (1) educação punitiva: o aluno tem prejuízos ao não corresponder ao padrão estipulado pelo docente, sem diálogo prévio com o corpo discente; (2) verticalização da relação professor-aluno: o discente é referido em um status hierarquicamente inferior ao do docente, o que se mostra durante o processo educacional, tanto na elaboração dos conteúdos e ferramentas pedagógicas, como também ao não dar ouvidos ao aluno, impossibilitando naturalidade na recorrência do aluno ao docente no sentido de dirimir dúvidas, assim como a impossibilidade de valorização da criatividade do discente e de sua autonomia no processo ensino-aprendizagem; (3) priorização da cultura do silêncio e silenciamento do corpo discente no processo ensinoaprendizagem: questão implicada na verticalidade da relação professor-aluno, trata-se da punição do discente quando este levanta questionamentos sobre ações e condutas, desmerecendo a dialogicidade necessária a um processo ensino-aprendizagem 
pautado na criatividade e na construção do pensamento histórico-político e críticosocial nos futuros profissionais; (4) falta de compromisso com o aprendizado do aluno: o docente demonstra preocupação em ministrar conteúdos e avaliar o quando o aluno corresponde com o padrão de memorização dos mesmos, e não se o aluno está realmente apreendendo e construindo conhecimento sólido pertinente aos mesmos.

Tem professor que faz muita diferença na nossa vida enquanto pessoa. Tem muitos outros professores que você tem que agradecer porque ele te machucou profundamente. 'Nossa! Eu aprendi com a professora Fulana de tal que era uma carrasca". Tem professor que educam para sermos inferiores a eles.

(AEnf 03)

Tem professores que tem prazer de reprovar aluno. Ficam caçando 'quero ver nesse período qual aluno eu vou reprovar'. Isso é um absurdo. O professor não está lá para reprovar aluno. Se fosse por isso não precisava de professor porque estava todo mundo reprovado.

(AEnf 03)

Tem professores que eu acho que não estão preocupados se você está aprendendo, mas em te humilhar, te botar para baixo. Não vêm aquilo que você estudou e aquilo que você sabe. Ele vai insistir em cima daquilo que você faz de errado, daquilo que você não soube. Te encosta na parede e pergunta, pergunta, pergunta... Tem professor que vai perguntando até você não saber que para te mostrar que você não sabe nada.

(AEnf 04)

$\mathrm{Na}$ Escola de Enfermagem é assim: o professor é o mestre, é o doutor entendeu. Tu não passa de um graduando. Com os professores novos não. A gente vê como colegas. Os mais antigos nunca te tratam como o tal. Sempre vão dizer 'o senhor acadêmico não tem opinião'. Se você não concorda com o atendimento de algum paciente, que deveria ser feito de determinado modo, mesmo que você esteja certo os professores vão dizer 'não senhora... eu to dizendo que é assim que tem que ser então assim que vai ser'. Você não tem opinião. Se você não tiver outra oportunidade extra na faculdade você sai muito imaturo e inseguro em relação a profissão.

(AEnf 04) 
Eu tive professores não tão bons. Não gostei muito. Se eu pudesse trocar, eu trocava. São hierarquizados mesmo. As tem 10 anos que ensina no hospital, que trabalha com seus alunos. Você pensa 'Deus me livre de ter que falar alguma coisa a determinado professor'... Tem coisas que você aprende de um jeito e o professor fala para fazer de outro. E você não consegue dar palpite em nada porque o professor não dá abertura. Agora, também tem os enfermeiros que trabalham nos serviços que eu acompanhei. Que são ótimos, que deixam você trabalhar com autonomia desde que você demonstre propriedade. Não tem melhor professora que esses assim, mesmo não sendo professores.

(AEnf 05)

É muito difícil para o acadêmico se acostumar com a cobrança no curso. É muita pressão: pressão do enfermeiro na unidade que não pode errar, pressão do teu professor porque quando você chegar você tem que saber tudo, você nunca foi para o hospital mas você tem que saber tudo. É assim. Você sente medo de fazer a medicação porque se fizer um negocio errado o paciente vai morrer. Tudo eu tinha medo de fazer. Sabe, eu achei bastante difícil para mim. Mas tem professor que não vê essa dificuldade, não está nem aí para essa dificuldade. E assim é pior.

(AEnf 04)

Eu criticava muito quando as coisas estão erradas. Sou clara, falo mesmo quando eu vejo que não está legal para o grupo, e o grupo fica calado. Até já fui prejudicada de falar. Acho que tinha que haver uma preparação antes dos professores começarem a atuar no estagio porque vem, fica falando coisa que não tem nada a ver com a nossa realidade e que você precisa fazer um procedimento que não tem material. Acho que deveriam colocar um profissional para estagio que conheça a realidade da nossa região.

(AEnf 01)

Para muitos dos meus professores às vezes você quer dar uma opinião é descartada. Isso acho que nunca deveria acontecer. Tem que considerar porque existe as críticas boas ou ruins, o que é importante para ele ver que ele não está tão bom, para melhorar, para fazer depois uma auto-avaliação.

(AEnf 01)

Tem uma professora que a gente tinha muita carrasca. Eu tinha muito medo de encontrar a professora em algum lugar. Quando chegou e ela era a responsável pela disciplina eu desanimei daquela atividade porque ela era muito carrasca. Mesmo se você usasse um brinquinho ela não aceitava, se fosse com o cabelo de uma forma ela não aceitava. Eram coisas mínimas que chamavam a atenção. Você tinha que estar lá 6:00 hs. Se você chegasse 06:01 hs ela já não 
aceitava. São esses detalhes que você querer falar alguma coisa para tentar modificar e os professores não aceitam.

(AEnf 01)

Este ensino pautado em uma posição eminentemente bancária, segundo o marco teórico freireano $35,36,79-88$, por refrear a criatividade e o desenvolvimento do profissional enquanto ser humano inconcluso e consciente de sua inconclusão, refletese em pensamentos críticos referente aos professores que conduziram o processo. As incoerências do sistema são mencionadas por estas acadêmicas, tais como a rigidez para com a postura do aluno no processo, em paralelo à conduta da não presença docente durante os estágios, apesar dos mesmos serem avaliativos; assim como da projeção do ideal docente para estas discentes, quando as mesmas apresentam que o professor deve pautar sua postura no lidar com os acadêmicos na formação de futuros colegas e não na postura de encará-los como futuros concorrentes, como pode ser observado nos depoimentos abaixo, quando se chega ao ponto de se negar informações sobre pós-graduação stricto senso às acadêmicas, já que as mesmas poderiam retornar e concorrer pela função docente no futuro. Também o medo de desmoralização frente ao professor é outra característica de uma educação silenciadora e que está presente no processo ensino-aprendizagem, segundo estas discentes de Enfermagem.

Acho que o professor deixou a desejar, no aspecto de acompanhamento dos alunos também (...) você fica numa unidade do hospital e a professora desaparecia, vamos dizer ia para outro local e só voltava na hora da gente sair. Mas na hora de dar nota, dava e prejudicava em muito a gente.

(AEnf 01) 
Se eu for professora vejo que você tem que formar pessoas da sua área. São seus colegas. Tem professor que não te ve como futuro colega. Vêem como futuros concorrentes. Por isso te formam para ser menores. Sinceramente não suporto e não gosto nem de falar porque até sobre mestrado eles nunca falam nada. Nunca. E quando a gente pergunta, eles se desviam 'tipo peixe que vai escorregando'. Alguns professores se encaixam naquele outro que eu te falei de professores que deixam um ensinamento muito grande, mas por outro lado a maioria não é assim.

(AEnf 03)

Às vezes a gente não sabe aproveitar as oportunidades por medo. Quando tem uma sonda para passar a professora pergunta 'quem quer passar vergonha'. Todo mundo observando o seu procedimento, com medo do professor te dar uma nota baixa, brigar na frente das outras pessoas por que eles geralmente fazem isso.

(AEnf 02)

A questão do preparo de alguns docentes para a atividade em sala de aula foi uma das características da educação bancária presente no curso de Enfermagem, na medida em que existem professores conteúdistas e depositários, os quais ministram aulas claramente não preparadas e utilizando-se do recurso do projetor multimídia. Segundo as entrevistadas, uma razão desta falta de preparo das aulas traduz o fato dos professores exercerem outras atividades além do ensino universitário. $O$ ensino bancário, aqui emblematizado no modelo pedagógico do curso de Enfermagem, possibilita que 'aula' seja um momento em que os conteúdos são narrados, sem atividades que caracterizem interação entre docente e discente, e com possibilidade de ser conduzido por profissional que não tenha se preparado para a mesma, na medida do conhecimento básico o mesmo apresenta mesmo sem esta preparação. $\mathrm{Na}$ medida em que é enfermeiro e que as projeções estão prontas. Na fala das entrevistadas fica registrada a falta de aprofundamento dos assuntos em aulas do 
curso de Enfermagem. Aulas que são ministradas neste formato, em que não há evidência de diálogo ou qualquer forma de interação entre professor e aluno.

O professor, às vezes, não tem muito tempo para se preparar. Chega, passa aquele slide ou data show, aquela coisa rápida, lendo o que está escrito. Falta mais aprofundamento do profissional, mais preparo.

(AEnf 02)

Tem professor que se não tiver data-show não dá aula.

(AEnf 01)

O enfermeiro tem muito trabalho: trabalha na unidade básica, trabalha na unidade hospitalar. Então o professor-enfermeiro tem muita dificuldade em coincidir ser professor e ser enfermeiro assistencial. Ele chega cansado para dar aula. Não há um preparo, pega o data show e só passa. Se for assim era melhor pegar um livro e estudar em casa.

(AEnf 04)

Outra característica da educação bancária existente no curso de Enfermagem, segundo a informação destas acadêmicas, retrata a tentativa de mudanças neste paradigma bancário por professores com pouco tempo de trabalho na IES investigada. A tentativa de mudar as estruturas cristalizadas deste modelo de ensino ocasionaram reação contrária dos professores conservadores e, conseqüente desgaste nos inovadores que, não agüentando a pressão, cederam e se retiraram do processo. Fato interessante é que alguns professores, mais jovens, ainda tentam mudar a estrutura. Outra característica é o fato destes docentes serem da área de Saúde Coletiva.

Haviam professores mais jovem que começaram a querer mudar as coisas na Escola, só que os outros mais antigos não permitiam. Eles não agüentaram e saíram.

(AEnf 01) 
Tem alguns que estão tentando mudar o tratamento com os alunos. Confio que isso vá para frente mas vai demorar um pouquinho. Tenho vontade de ir para lá e ser uma dessa professoras que tenta mudar um pouquinho.

(AEnf 03)

Existem professoras que ainda tentam mudar as coisas. Elas têm nossa idade. Pelo fato de terem a nossa idade e ela ser tão competente, me faz assim admirar muito mais a saúde pública. Fiquei apaixonadíssima!

(AEnf 02)

De forma paradoxal à postura bancária, as acadêmicas apontaram como ideal a postura de alguns professores problematizadores, cujas principais linhas de conduta pautam-se na horizontalidade da relação com o discente e clara percepção sobre a preocupação com o ensino que estes docentes demonstram, segundo as entrevistadas. São características da educação problematizadora presentes na conduta destas docentes, segundo as informações das entrevistadas: (1) proximidade entre o aluno e o professor: presença de vínculo pessoal e intersubjetivo de tal maneira que o discentes alude a figuras parentais ao se referirem ao docente; (2) entendimento do aluno como ser humano: clara percepção de que o ato de ensinar é ensinar ao ser humano, sendo as docentes referidas como humanizadas; (3) interesse em dirimir dúvidas e deficiências do aluno no processo ensino-aprendizagem: condução do processo de forma que o discente possui abertura para buscar esclarecimento de forma natural, sem temor de ser repreendido ou silenciado; (4) professor tomado como arquétipo da futura prática profissional: o docente é aludido como o modelo de futuro profissional em que o aluno deseja se refletir; (5) horizontalidade no processo ensino-aprendizagem: diferente de estipular conteúdos e caminhos traçados 
previamente para o aluno transitar, os docentes guiam pelo processo mas permitem que os alunos busquem por si mesmo seus desafios e formas de crescimento, no entanto de forma presente e conjunta com o discente; (6) problematização dos conteúdos: o docente não apenas teoriza sobre os conteúdos, mas atrai a teoria para a vida-vivida e, com isso, não apenas cria o interesse do discente no processo, como também faz com que o ensino seja articulado com a prática.

Algumas professoras são muito "mãe". Trabalhavam mesmo a humanização. Uma que é maravilhosa a gente vai até fazer uma homenagem para ela na formatura. Chegavam com paciência conversando, tinham aquela aproximação mesmo.

(AEnf 01)

Tem professores que são amigos mesmo, aquela pessoa que você pode sentar, falar tudo, inclusive coisas que não são de Enfermagem. As vezes a gente tem professor que senta lá para tirar duvida. Tem uma professora que eu gosto demais. Ela me ajudou bastante, sentava, eu contava as coisa para ela e ela me ouvia. Foi uma mãe mesmo.

(AEnf 03)

As professoras são como um espelho: cada AEnf tem um pouco de aprendizado com elas, leva consigo e quando for atender um paciente pensa logo nelas.

(AEnf 01)

Mas tinhamos professores mais próximos, mas preocupados, que sempre ensinavam para a gente aprender. Eles nos davam um caminho para que a gente fosse buscar.

(AEnf 04)

Tinhamos professores que também eram muito preocupados, tanto é que vários professores diziam assim 'vocês vão ser enfermeiros'. A gente vê o peso que era ser enfermeiro não é só dizer que sei desempenhar o trabalho do profissional mas eu tenho que mostrar o meu conhecimento. 'Vocês tem que saber o máximo que vocês podem saber isso'.

(AEnf 02)

Nós observamos os enfermeiros e a gente vai traçando o nosso perfil. Cada enfermeiro que a gente observa a gente pegando alguma 
coisinha. Se nosso foco é na saúde pública, então a enfermeira do posto que a gente está agora, por ser muito boa, muito humana, a gente se espelha.

(AEnf 02)

Mais uma vez, as informações da imersão no modelo pedagógico do ensino de Enfermagem, na IES investigada, apontam em direção à predominância do ensino tradicional, bancário e narrativo, de enfoque conteúdista, quando comparado com a postura pessoal de alguns professores, em menor número, que se mantém com um enfoque pautado no ensino libertador. É interessante notar que estas acadêmicas identificam claramente tanto as diferenças entre ambos, como valorizam os últimos, apontando para como se mostra humano o processo ensino-aprendizagem pautado na perspectiva libertadora ${ }^{35,36,79-88}$.

\subsubsection{Terceira Categoria: a humanização no modelo pedagógico}

A questão da humanização na assistência em saúde foi apresentada como uma característica importante e necessária a ser trabalhada no curso de Enfermagem, principalmente pela característica de estar lidando com saúde de seres humanos e, ser humanizado, mostra-se necessário na medida em que, para estas entrevistadas, o enfermeiro não trabalha com um objeto, mas sim com um semelhante.

Principalmente na área da saúde qualquer erro pode prejudicar muito. Esses deveres humanos nossos para com os outros são bem maiores e existem.

(AEnf 04) 
Seres humanos são nosso objeto de trabalho que não é bem objeto. Tem uma responsabilidade muito maior e um dever humano.

(AEnf 02)

É muito grande é uma responsabilidade gigantesca lidar com o ser humano.

(AEnf 03)

O tema da humanização é discutido apenas recentemente na Enfermagem, segundo as entrevistadas, sendo que a atenção humanizada era mais uma característica pessoal do que propriamente uma característica própria da ação de Enfermagem, antes desta temática tomar importância. A matriz curricular do curso vivenciada por estas acadêmicas não previa disciplinas ou discussões sobre humanização nos períodos iniciais do curso, sendo uma abordagem mais tecnicista dos aspectos da Enfermagem.

Há 4 anos pouco se falava em humanização em Enfermagem. Quando nós entramos no primeiro ano de graduação ainda eram coisas novas, era como se fosse uma utopia que falava muito mas não era posta em prática, não existia, ficava longe de fazer parte da Enfermagem. As pessoas que faziam era pela sua própria pessoa, como uma qualidade dela, de tratar as pessoas com humanidade, tratar as pessoas com delicadeza.

(AEnf 02)

Principalmente no $1^{\circ}$ período a gente nunca ouvia falar em humanização. A gente tinha que aprender a parte técnica para gente poder saber que ia ser cobrado mais no futuro, mas era mais a parte técnica mesmo que focavam as disciplinas.

(AEnf 04)

No $1^{\circ}$ e no $2^{\circ}$ ano eu nem sabia o que era humanização, quando falavam humanização em Enfermagem nunca passava pela minha cabeça o que era. Aí quando chegou na obstetrícia tudo foi se abrindo. Aí que eu fui associar as coisas que eu ouvia falar sobre humanização. Isso mais ou menos nos 2 últimos anos.

(AEnf 03) 
A humanização foi trabalhada como temática em poucas disciplinas, em particular, nas disciplinas de fundamentos de Enfermagem, obstetrícia e psicologia. As acadêmicas justificam que estas disciplinas trabalham o tema, na medida em que se tratam de momentos em que se lida com o paciente, à exceção de psicologia que trata teoricamente sobre o assunto. Segundo a percepção do grupo, o relacionamento aberto e claro com o paciente é um aspecto do atendimento humanizado, sendo necessária à prática de Enfermagem, uma necessidade mais evidente em situações extremas, como a de pacientes terminais.

A humanização só foi trabalhada diretamente em fundamento de Enfermagem, porque é o momento que você vai entrar para fazer os estágios nas comunidades. É muito trabalhada essa parte da humanização, de como vai atender seu paciente. A questão de não esconder nada do paciente. De quando o paciente está com uma doença terminal a gente tem que chegar e tentar conversar com ele, que ele vai passar inúmeros processos.

(AEnf 01)

Todas as professoras mencionam a humanização. Claro que tem professores que a gente percebe que elas são mais humanizadas, se inserem mais. Tem outras que falam discretamente mas sempre nós tivemos este discurso, mesmo nos que não são.

(AEnf 03)

Quase todos os nossos professores falavam sobre valorizar a humanização.

(AEnf 04)

A humanização foi trabalhada por algumas professoras naqueles momentos que a gente não tinha nada para fazer. Orientavam que naquele momento que você não está fazendo nada, para a gente ir lá e ouvir a historia do paciente, para saber o que está se passando, quais as dificuldades. Alguns professores realmente nos cobram ter um relacionamento aberto com o paciente porque nós éramos todos iguais.

(AEnf 02) 
Quase todos os nossos professores falavam sobre valorizar a humanização.

(AEnf 05)

Principalmente na obstetrícia se falava muito na humanização do trabalho de parto, a humanização do toque na hora que a mulher ia ter o bebê.

(AEnf 02)

Tinha aquelas disciplinas a psicologia $I$, de como é que os pacientes se comportavam da necessidade do paciente, então assim agente tinha q identificar as necessidades os aspectos que ele está precisando naquele momento a preocupação com o nível econômico mais baixo agente tem que saber aborda-lo.

(AEnf 02)

Na graduação era mais em obstetrícia que os professores falavam sempre sobre assistência humanizada. Não que os outros não valorizassem, mas não falavam muito, não conseguiam se expressar e não passavam para que a gente precisasse de humanização naquela determinada matéria porque quando agente estava estudando a gente tem assim uma visão mais ampla, a gente vê o especifico, todos os professores falavam sobre isso mas na obstetrícia toda hora.

(AEnf 02)

O trabalho pedagógico sobre humanização também foi aludido como presente nos discursos dos docentes seja entre aqueles que são considerados de conduta humanizada, seja entre os que não a demonstram. Percebem que há cobrança sobre este relacionamento humanizado, segundo o conceito construído sobre humanização, que, de maneira predominante, refere-se ao entendimento do paciente como semelhante. As acadêmicas referem necessidade de ações específicas sobre humanização durante o curso, e não apenas para o curso de Enfermagem, mas para todos os cursos da área de saúde.

Falta trabalho específico sobre humanização. É importante você trabalhar a humanização em todas as disciplinas no decorrer do 
curso, se seja Enfermagem, de educação física de qualquer área. A humanização tem que estar presente, porque as pessoas precisam muito ser trabalhadas nesse aspecto.

(AEnf 01)

Acho que isso a gente trabalha na pratica com professor. Às vezes em sala de aula como se relacionar, mas ter uma disciplina para isso não.

(AEnf 04)

Sobre a abordagem dos aspectos sociais do paciente na construção do conhecimento dos graduandos de Enfermagem, as entrevistadas apresentam que a temática é objeto de estudo de diversas disciplinas, apenas de forma teórica e não articuladas com a realidade. Também que na vivência clínica não existe discussão sobre estes aspectos específicos do paciente. Silenciam sobre a importância desta abordagem ou de suas conseqüências para o processo saúde-doença e na promoção de saúde na atuação dos enfermeiros, ou mesmo se estas perspectivas foram discutidas durante o processo ensino-aprendizagem em Enfermagem.

Sobre a parte social a gente trabalha assim no geral. Por exemplo, trabalha-se patologia, antropologia, psicologia. Tudo na graduação mas não especificamente sobre o paciente, mas sim no geral.

(AEnf 04)

Acho que a convivência dentro do hospital é que de verdade foi me moldando como profissional, mas a faculdade prepara bem apesar de que as vezes é muito curtinho o tempo que a gente passa na clinica e não dá para a gente entender o paciente como um todo, pelo lado social.

(AEnf 03)

A questão da humanização no modelo pedagógico de Enfermagem novamente foi apontada como um dos silêncios em termos operacionais na matriz curricular, haja 
vista ao fato de que há menção teórica sobre a temática, mas não se debate como aplicar os conceitos no cotidiano da prática profissional do enfermeiro, novamente apontando para a dicotimização entre teoria e prática, além da desarticulação do ensino com relação a vida-vivida do profissional de saúde $\mathrm{s}^{35,36,79-88}$.

\section{4a Categoria: A humanização na prática de Enfermagem.}

Sobre a conceituação do que é Humanização, para as acadêmicas de Enfermagem este conceito é similar ou mesmo sinônimo de acolhimento. Nesse contexto, o vínculo entre o profissional de saúde e o paciente é requisito para a prática humanizada. A função do profissional de saúde está em suprir necessidades não relacionadas estritamente a patologia, mas sim a dimensão emocional e ao que esta afeta o paciente no momento do atendimento. Pensar no paciente como semelhante é característica da humanização, segundo as entrevistadas. A assistência humanizada também implica em fazer todo o possível pelo paciente, além do fato de ser encarada como uma contraparte da assistência de saúde técnica, algo dissociado, que ocorre em paralelo, como se o enfermeiro, no ato clínico, pudesse tratar o paciente apenas tecnicamente ou também de maneira humanizada, e esta fosse uma etapa a mais do atendimento de Enfermagem.

Todo ser humano é igual. Todo ser humano merece ser tratado da mesma forma. Isso depende muito do ser humano que você é, porque eu acredito na questão de caráter. Como você tem coragem de tratar diferente porque ele é rico e como você tem coragem de tratar mal aquele outro porque ele é pobre? Isso não se ensina na faculdade mas todo dia acontece depende de cada um.

(AEnf 03) 
O profissional de saúde procura ajudar naquele momento o paciente. Ele sente também pelo paciente: se está triste, ele fica triste. "eu vou fazer algo para mudar. Tenho que fazer ele ficar alegre". O profissional de saúde se coloca no lugar do paciente.

(AEnf 01)

O paciente e o profissional são iguais, mas, claro, tem um limite.

(AEnf 04)

Enquanto pessoa, todos são iguais. Tanto é que tem determinadas situações que, se for falar para Enfermeira, pedir alguma coisa que seja fora da regra, fora da rotina, ela fala 'se fosse comigo eu queria que tivesse se passando, então eu vou fazer por você, porque eu sei que você está precisando, somos pessoas iguais'. Sempre agente se coloca no lugar do outro, para estar satisfazendo a necessidade daquele momento.

(AEnf 02)

Para cuidar de uma pessoa tem que ser humano. A gente tem que cuidar como se fosse um dos nossos parentes, fazendo o melhor que agente pode fazer. É se doar mesmo. Diz na Bíblia que a gente tem que amar o próximo como a si mesmo. Se estou fazendo o bem, estou fazendo o máximo que eu posso. Acho que é um dever humano.

(AEnf 03)

Humanizar não é apenas tratar bem. Humanizar é você estar procurando dentro daquela sua área fazer o melhor para aquela pessoa.

(AEnf 03)

Faz diferença uma assistência humanizada. Como faz diferença! Acho que poderia ser assim: metade humanizada e a outra metade o que realmente o paciente precisa. Há grande diferencial nas instituições privadas. Eles pregam muito a satisfação do cliente porque eles querem que tudo seja melhor, fazem que as assistências sejam humanizadas. Na instituição publica é 'uma escada a ser subida', mas está indo.

(AEnf 02)

A postura individual decorrente de fatores relacionados a história pessoal dos profissionais de saúde foi apontada como implicada na humanização posterior a graduação. Segundo as entrevistadas, a história familiar de cada profissional, assim 
como sua personalidade são relacionadas a quanto o profissional tomará condutas humanizadas ou não no atendimento de Enfermagem, sendo que o curso universitário dá bases para a mesma. A prática de Enfermagem é entendida como atividade em que o tratar do ser humano como semelhante está implícito no próprio ato de Enfermagem, desde atenção emocional ao paciente até questões como a higienização, alimentação e cuidado a acamados.

É de dentro de cada individuo. Seus pais já vão moldando o que é certo, o que é errado. Eu acredito que isso também é muito ligado a ética enquanto profissional.

(AEnf 03)

A faculdade prepara muito bem. Claro que ela não muda sua personalidade.

(AEnf 03)

A Enfermagem é a arte de cuidar. Você não ganha muito dinheiro, não pensa que você vai ficar rico sendo enfermeiro que você não vai, mas só pelo fato de cuidar, de você ver aquela pessoa, é muito legal.

(AEnf 01)

O profissional tem o dever de ajudar, de dar assistência naquele momento mais difícil daquele paciente. Tem que colocar na cabeça que o paciente que está ali não está precisando apenas de medicamento, mas de um aperto de mão, de um carinho.

(AEnf 01)

O enfermeiro está no serviço para resolver as necessidades básicas dos outros. O que são essas necessidades básicas? Você precisa ir ao banheiro, precisa dormir, precisa ter paz, no momento que você está com dor precisa resolver aquele problema, precisa muitas vezes até de uma palavra.

(AEnf 04)

O profissional de saúde tem que ajudar naquele momento para socorrer aquela pessoa que esta ali, tão debilitada, precisando um pouco de carinho, um pouco de amor, de atenção.

(AEnf 01) 
A humanização do atendimento foi uma temática imbricada em diversos conceitos que se contradizem nos discursos deste grupo. Segundo as entrevistadas o atendimento humanizado apresenta certa carga de pessoalidade, sendo que, em casos em que haja simpatia entre o paciente e o profissional, estabelece-se uma relação empática entre ambos. Este conceito aproxima-se muito da perspectiva da humanização como acolhimento no atendimento, o tratar bem e humanitariamente, o que se revela pelo grau de apego pessoal que o profissional cria em relação ao paciente, havendo pacientes que o profissional se apega mais e outros que ele se apega menos, ou não se apega. Segundo as entrevistadas, apesar da importância da humanização do atendimento, segundo seus próprios conceitos, e que o atendimento deva ser humanizado para ser realmente efetivo, a despeito de ser encarado como integral ao ato clínico de Enfermagem ou como uma das dimensões possíveis do mesmo, afirmam que podem estabelecer estes vínculos ou não estabelecê-lo, na decorrência de ser criada relação empática ou não com o paciente. E mesmo assim, apontam que o tratamento ao paciente será o mesmo em ambos os casos, na medida em que pautam 'o atender igual' a questão da técnica e não da condução da mesma e as dimensões intersubjetivas destas conduções.

Eu vejo que alguns pacientes a gente se apega mais. $O$ vinculo é maior. Tem outros que não, nunca a gente vai deixar de fazer a técnica certa, fazer o procedimento certo, mas tem outros pacientes, não que a gente se dedique mais porque isso não existe, mais que a gente se apega mesmo, nosso lado afetivo. Eu acho que algumas vezes tem diferença entre como a gente atente um e outro paciente.

(AEnf 03) 
O procedimento é igual para todos. Só o que diferencia é o nosso lado afetivo e dentro de mim. Acho que para o paciente isso é muito bom.

(AEnf 04)

$O$ procedimento é o mesmo. Tem a mesma forma, por que acima de tudo você tem que respeitar o ser humano. Todos são seres humanos e não importa se eu sou mais apegada com o do leito 01 ou o paciente do leito 02 .

(AEnf 02)

Lembro de uma situação, eu não tinha entrado na graduação, meu pai estava com a pressão muito alta e fomos a um pronto socorro. Ele foi bem atendido e tudo mais. A pessoa sente quando é querida faz um atendimento diferenciado. Isso depende de lugar para lugar.

(AEnf 02)

O Hospital Universitário Getúlio Vargas é o maior estágio para Enfermagem. Meu pai foi internado lá antes de meu ingresso. O tratamento foi muito ruim. Até para ele pedir uma coisa simples como um papagaio era muito difícil o contato com a Enfermeira. As vezes muito agressiva, tratava mal o paciente. Depois, quando eu comecei a estagiar aí o tratamento já modificou. Passei a ser estudante, AEnf. Como já me conheciam o tratamento para meu pai ficou diferente. Por isso, quando eu chego tento mostrar de uma forma que sou acadêmica para que eu seja bem tratada, mostrar que eu tenho conhecimento sobre aquela patologia, sobre aquela doença sobre determinada coisa, para que eles não venham me maltratar.

(AEnf 01)

A realidade de estar na condição de paciente foi aludida pelo grupo como uma situação de dificuldade, indesejosa e fragilizadora do ser humano, caracterizada pelo desconhecimento sobre os atos que serão tomados e a falta de influência do próprio paciente sobre as condutas para o restabelecimento da saúde. Neste contexto, existe troca entre o profissional e o paciente, na medida em que o primeiro se encontra como prestador de serviços de saúde e que o último encontra-se em necessidade. As entrevistadas apresentam que, nesta relação, existe horizontalidade, já que não apenas o profissional presta serviços, mas também aprende e se modifica, por que se 
trata de uma relação humana, entre seres humanos. Inclusive mencionam que o lidar com pacientes ocasiona mudanças nos profissionais em nível pessoal.

Não sei dizer se é frustrante, mas é muito horrível você se ver como paciente. Porque você está acostumado com a doença, com a emergência, com pronto-socorro, com atender pacientes em todos os locais. Mas é muito diferente quando a gente se encontra como paciente. De repente não sabe nem para que serve aquele medicamento que você está tomando. Bate um desespero. Você passa a ser leigo no assunto e é bem interessante. É uma experiência que contribui.

(AEnf 04)

Porque é uma troca: é o meu emprego, eu estou ali para prestar cuidado para o paciente como pessoa, como doente, como necessitado de assistência. Mas eu vejo também que nós, toda vez que vamos no hospital, que saímos do hospital, a gente aprende alguma coisa. Faz diferença porque a gente está lidando direto com o ser humano. A gente aprende bastante. Tem coisas que você faz diferente porque aquele paciente te mudou de uma certa forma. $\mathrm{E}$ isso é um dever humano com ele, ele também tem comigo, porque é troca toda hora.

(AEnf 03)

As depoentes apresentaram que existe complexidade nos determinantes de saúde. E que esta complexidade acompanha o paciente. A percepção do paciente foge da perspectiva biomédica estrita. Apesar das características biológicas envolvidas no ato clínico, também não escapa do profissional que o paciente é um ser humano, que se relaciona com outros seres humanos, que está vinculado a um modo de produção capitalista, em que os fatores socioeconômicos apresentam influência direta na vida. Ao paciente procurar o serviço de saúde este entorno o acompanha e se revela ao profissional de saúde junto a doença trazida. Ao mesmo tempo, a atenção de saúde tem peculiaridades como o lidar com vidas, e este lidar com vidas se revela tanto na 
consulta, como nos passos seguintes da atenção, como a administração de medicamentos ou o retorno do paciente para sua residência após a intervenção, questões pragmáticas que muitas vezes tornam o foco do profissional na atenção distante do entorno mencionado acima.

Como você esta lidando com ser humano não tem como separar, tratar apenas da doença. Não tem como você separar uma pessoa doente dos seus problemas pessoais, dos problemas sociais. A gente acaba se envolvendo.

(AEnf 03)

Assim como pode salvar a vida de uma pessoa, você pode matar. Já até aconteceu com uma colega administrar medicação errada, por via errada. Era intramuscular e ela aplicou endovenosa. Não teve problema, mas vamos dizer que tivesse. Como você pode salvar dando aquela medicação para melhorar o quadro do paciente você poderia ter matado o paciente.

(AEnf 04)

Na clinica cirúrgica o dever social é enorme, no sentido do transporte do paciente para voltar para casa até a forma de como é que ele vai vir aos exames que são caríssimos. Nem sempre o hospital pode auxiliar. $O$ enfermeiro tem que prever o estoque, toda aquela parte social.

(AEnf 05)

A proximidade do enfermeiro junto ao paciente, no ato do cuidar, em muito está implicada na postura humana destas acadêmicas. Assim como esta proximidade permite ao acadêmico de Enfermagem o vivenciar da percepção da dor do outro no serviço de saúde. No entanto, ainda permeia a estrutura do ensino bancário influenciando a postura destes acadêmicos enquanto profissionais, haja vista ao fato de que, apesar do discurso de acolhimento, revelam que humanização é tratar bem, o que muitas vezes é negado dadas as peculiaridades do relacionamento entre paciente 
e profissional. Silenciam novamente como implementar ações para a humanização, no sentido freireano ${ }^{35,36,79-88}$.

\subsubsection{Quinta Categoria: Desafios à humanização}

Com relação às barreiras existentes para o atendimento humanizado, o stress do profissional no serviço de saúde é apontando como um fator desumanizar, inclusive sendo o atendimento por enfermeiras estressadas utilizado como antônimo do atendimento por enfermeiras humanizadas.

O ambiente hospitalar foi apresentado como um ambiente em que a humanização não ocorre de maneira natural, uma vez que os motivos que levam os pacientes ao serviço referem-se às condições de complicações clínicas e, até mesmo pelo significado de estar hospitalizado, os pacientes se encontram em fragilizados. Peculiaridades do serviço hospitalar seriam promotoras de um maior estresse nos profissionais neste ambiente. Em decorrência, o profissional de saúde que, segundo as entrevistadas, é o ser humano em melhores condições neste processo, deve entender esta condição especial do paciente, principalmente no que se refere a dimensão emocional do mesmo e de sua família. O próprio enfermeiro, como ser humano, é suscetível de ser hospitalizado e, como tal, deve entender que as demandas do paciente durante a hospitalização são suas próprias demandas, caso estivesse nesta condição. Este entendimento é um pré-requisito para o atendimento humanizado, de fundamental importância já que o enfermeiro é apontado como o profissional que 
mais tempo está com o paciente, sendo de fundamental importância sua postura humanizada, segundo a perspectiva das acadêmicas entrevistadas.

Nem todas as enfermeiras são assim. Tem muitas que usam a humanização, mas tem outras muito estressadas.

(AEnf 01)

Nosso ambiente é ser humano com ser humano. Todos os ambientes de trabalho são assim só que o nosso, a gente está inserido em um ambiente onde outro ser humano está fragilizado. As vezes ele falha com dever moral dele, ele falta com dever ético talvez não porque ele queria realmente não estar alí. Porque aquele momento é tão deprimente, uma situação muito precária. Aí eles faltam com respeito mesmo. Talvez a gente possa até entender alguns momentos desses. Agora, no nosso lado profissional também não agir com ética, não agir assim respeitando o outro já complica um pouco mais. A gente não pode se permitir. Mas acontece sim.

(AEnf 03)

O estresse é tão grande no ambiente hospitalar que passa para o paciente, para o acompanhante. É bem difícil. Falta melhorar, ter conscientização, ter humanização. Isso é horrível para o paciente para o acompanhante que estão ali, naquele ambiente e você sabe que ele não está ali porque quer. Se está ali, está com problema. Você tem que fazer o seu trabalho. Seu problema pessoal deve ficar para depois. Quando chegar na minha casa eu resolvo, mas lá, no meu ambiente de trabalho, eu não posso misturar. Pode estar triste, pode estar com raiva, mas você vai fazer o seu trabalho. Se você não consegue, não vai trabalhar. É melhor você ficar em casa.

(AEnf 02)

A enfermeira é muito necessária. A gente costuma dizer que o médico trata da doença. Vai lá, prescreve e vai embora. Prescreveu vai ficar no papel se não tiver Enfermagem. As vezes o paciente tem alteração que o médico não percebe porque só faz visita de manhã e vai embora, enquanto o enfermeiro fica lá quando o paciente precisa de alguma coisa. 0 enfermeiro é o primeiro que percebe as alterações.

(AEnf 03)

O enfermeiro ou qualquer profissional de saúde tem que ter a noção de que está trabalhando com pessoas, com pessoas de carne e osso e que têm sentimentos. Tem que tratar o paciente da mesma forma como gostaria de estar sendo tratado. A gente é 
enfermeiro mas também pode ser paciente porque nós somos de carne e osso, nós adoecemos, temos as nossas necessidades.

(AEnf 04)

A necessidade da presença do enfermeiro junto ao paciente é relatada como de grande importância para estas acadêmicas. A experiência prévia a graduação de algumas delas demonstra que esta é uma barreira a humanização. Não é sempre que as enfermeiras efetivamente acompanham os pacientes, muitas vezes delegando estas funções aos técnicos de Enfermagem. A necessidade de o enfermeiro efetuar este acompanhamento está imbricada com a competência profissional desta categoria, na medida em que a profissão tem o cuidado como área privilegiada de atuação.

Nunca tive oportunidade de ter contato com enfermeiros antes da graduação. Uma vez tive de ficar internada no hospital e realmente eu não tive a presença do enfermeiro. Só dos técnicos, que são os profissionais nível médio, o tempo todo lá comigo, mas a presença do enfermeiro eu não tive.

(AEnf 01)

Eu não concordo que o enfermeiro não esteja sempre com o paciente porque $o$ que a gente aprende na graduação, $o$ que a gente faz não é isso. Tem que ter pelo menos a visita diária.

(AEnf 02)

Você tem que estar fazendo com seu paciente, você vai conhecer seu paciente. Você tem que todo dia fazer uma visita de leito em leito, ver como o paciente está. Porque isso que é Enfermagem. Se você não visita você não está lá como enfermeiro. Você esta lá como bombeiro para apagar o fogo. Aconteceu uma emergência você vai, mas não é o objetivo da nossa profissão.

(AEnf 04) 
Isto posto, as acadêmicas de Enfermagem percebem dificuldades estruturais e da formação do recurso humano em saúde, como desafios a plena humanização, o que vai de encontro ao pensamento freireano ${ }^{35,36,79-88}$.

\subsubsection{Sexta Categoria: Ética, direitos e deveres do paciente}

A ética é entendida como uma forma de valorização do ser humano, traduzida em leis que regulamentam as posturas necessárias ao atendimento em saúde. É aludida como um fator implícito ao atendimento em saúde, na medida em que a ética protege o ser humano que está sob os cuidados do enfermeiro. De grande significado para as entrevistadas, as questões éticas são transversais a todo o serviço de saúde e não deixam de estarem presentes em nenhuma área deste setor de serviços. Retrata a postura dos profissionais, na medida em que as entrevistadas acreditam que o agir ético refere-se em uma dimensão interna das pessoas.

Na área da saúde você tem oportunidade de prestar cuidado ao ser humano e respeita-lo como tal, respeitar através da ética profissional, a ética com ser humano, a ética como pessoa. Eu acho que a responsabilidade nossa é muito maior.

(AEnf 03)

O profissional tem que ter ética por si mesmo, não como se fosse um dever. A ética deveria ser seguida independente de ser um dever. Tem que ter postura, moral. Na relação com o paciente e com os colegas.

(AEnf 02)

Todo ambiente que a gente está a ética está junto. Muita gente pensa que ética é só aquela ética que está escrita. Não tem que ser assim.

(AEnf 02) 
A principal função da ética é servir como instrumento regulatório das ações dos enfermeiros. Apresenta uma função de ordenamento, de forma que sem a ética seria instaurado o caos. Ações que não se pautem em condutas éticas interferem negativamente no tratamento dos pacientes, além de que é a ética que regula os limites da Enfermagem, em relação às outras profissões de saúde.

Tem que haver em toda profissão a ética, porque se não haver em toda profissão a ética fica tudo bagunçado. Tenho que saber qual é meu direito e qual é o meu dever também.

(AEnf 03)

Acho que ele está lá como paciente. O profissional que tem que ter a ética e saber lidar e saber aceitar o momento do paciente.

(AEnf 04)

Se o profissional não trabalha com a ética, com humanização, vai interferir no tratamento do paciente.

(AEnf 01)

Eu não vou fazer determinada coisa porque não está dentro da minha legislação, não está dentro do meu código, o código não me ampara. Se eu for prescrever uma medicação, no interior do Amazonas nós observamos que o enfermeiro prescreve igualmente $o$ médico, pode dar complicação, algum efeito adverso. Aí a pessoa talvez não tenha conhecimento, mas se tiver vai processar o enfermeiro. $O$ código de ética não ampara porque lá não tem um parágrafo que o enfermeiro pode prescrever.

(AEnf 02)

No que se refere aos pacientes, são diversos os limites éticos do enfermeiro. A observância do sigilo e da preservação da intimidade/privacidade do paciente foi apontada como um baluarte ético na atenção de Enfermagem. Também foram mencionados como direitos dos pacientes e que os enfermeiros, por questão ética, devem permitir: a presença do acompanhante no ato clínico, o diálogo aberto e claro 
para o esclarecimento sobre a situação da saúde do paciente, e a consulta ao paciente sobre se este se sujeitará ou não a conduta estipulada pelos profissionais de saúde frente a demanda clínica.

A gente tem que respeitar a privacidade do paciente. Isso é colocado na academia: se você vai fazer qualquer procedimento, tem que respeitá-lo. Mesmo que, por exemplo, o paciente esteja há muito tempo na enfermaria você tem que respeitar a privacidade dele, protegê-lo de qualquer pessoa que esteja ao lado para não deixar ele exposto.

(AEnf 01)

O paciente tem direitos e pode cobrá-los. Vejo que muitos profissionais não querem que o paciente tenha seus direitos assegurados. Muitos enfermeiros, muitos profissionais não querem que o paciente veja o acompanhante, vejam seus prontuário. Antigamente deixavam longe do paciente para ele não ver a medicação, o que estavam tomando, o diagnóstico. Agora não, fica lá na cabeceira do paciente. Ele já pode ver. Ele tem o direito disso e o enfermeiro não pode dizer não. $O$ enfermeiro tem o dever de falar e o paciente o direito de saber.

(AEnf 01)

Depende de cada um. Por lei o paciente tem que saber tudo que diz respeito a ele, a respeito da doença dele, o motivo da internação e se o tratamento vai ser mesmo eficaz. O paciente tem que saber o que está ocorrendo com ele. Só que tem profissionais que preferem não falar tudo, as vezes para poupar o paciente, as vezes porque existem pessoas desesperadas e, se você fala um pouquinho, ele não compreende e já transforma 'num temporal'. Tem que ter jeito. Eu falo tudo. Só que, até para dizer a verdade, tem que ser com amor. Você pode me perguntar: dizer a verdade com amor? Como assim amor? Dizer de uma maneira que o paciente entenda, de uma maneira que não vai feri-lo. Já que a gente aprende todo procedimento, vai poder explicar porque e como é que vai acontecer. $O$ paciente pode se recusar a ser submetido ao procedimento caso ele não sabe para que é aquilo nem é obrigado a saber coisa da área do outro.

(AEnf 03) 
Paralelamente aos direitos dos pacientes, alguns deveres para com o profissional foram mencionados pelas entrevistadas já que, muitas vezes, o enfermeiro não consegue atender as necessidades e solicitações dos pacientes imediatamente. Isso gera conflitos, na medida em que o paciente encontra-se fragilizado e impaciente. Segundo as entrevistadas os pacientes não deveriam discutir ou se alterar no trato com o enfermeiro, na medida em que, inclusive, pode ser desenrolado processo por desacato ao servidor público ou ser dispensado do atendimento, caso se comporte assim.

Às vezes o paciente está fragilizado, numa situação de risco. E ele quer tratar todo mundo mal, acha que tem que ser o centro das atenções e não respeita os profissionais ou pessoas que estão lá com ele. $O$ paciente tem que respeitar, tem o dever humano de saber respeitar tal situação.

(AEnf 02)

Ás vezes o paciente não quer saber sabe se você está ocupado. Muitas vezes fica impaciente, porque passa muito tempo no hospital, perde a paciência porque ele quer ir embora. A gente tem que entender isso. Alguns pacientes são meio ignorantes e querem ser atendidos, não querem saber das regras do hospital, querem entrar ver o paciente que está lá, o seu acompanhante na verdade, se tem alguém na frente dele, se tem muito paciente. Quer ser atendido de qualquer forma. Com tudo isso ele já vai passar o limite que existe naquele hospital. Vai passar a desautorizar o enfermeiro, o profissional de saúde que está ali.

(AEnf 01)

Tem uma lei que se você agredir o profissional corre o risco a 2 ou 3 anos de presão. Não pode fiança.

(AEnf 05)

O paciente tem o dever legal de respeitar o profissional que está ali trabalhando. Qualquer coisa ele pode ser mandado embora.

(AEnf 01) 
Apesar da verbalização de conceitos e da importância da ética como reguladora das relações profissionais, a dimensão humana nestas relações frente ao caráter regulatório da ética profissional não esteve presente nos discursos, encaminhando a análise ao silêncio sobre a humanização enquanto prática transversal no atendimento em saúde ${ }^{35,36,79-88}$.

\subsubsection{Sétima Categoria: prática de Enfermagem e saúde coletiva}

Na prática do enfermeiro em Saúde Coletiva, é necessário que o mesmo se articule com os diversos setores da sociedade, o que caracteriza a ação social da profissão, segundo as entrevistadas. Estes diversos setores refletem a própria articulação dos pacientes em suas realidades, que o enfermeiro deve acessar ao se propor a realizar ações de saúde, inclusive, por que, muitas vezes, a realidade do paciente não permite que tenha condições de seguir o que é preconizado pelos profissionais de saúde.

Apontam que a disciplina de sociologia trabalhou estes conceitos. Esta atuação do enfermeiro perpassa a questão da educação em saúde percebida por estas acadêmicas como eminentemente relacionada à prevenção de doenças e agravos de saúde. Apesar do claro entendimento destas questões com significativa importância para a atuação do enfermeiro, a sobrecarga de trabalho nos serviços de saúde é justificativa para a não atuação em relação ao entorno social do paciente, por mais que haja influência do mesmo nas questões de saúde. 
O enfermeiro tem dever de participação na parte social, por exemplo, na igreja na determinada comunidade explicando determinada doença, ajudando no que for preciso na parte da saúde para aquela sociedade, para aquela comunidade.

(AEnf 01)

Na parte social a gente tem indiretamente em todas as matérias que a gente tem passa... Para analisar o lado social da pessoa. Muita gente não põe em pratica porque muita gente não tem condições. Você tem que ir atrás de, por exemplo, uma fralda. 0 paciente não tem as mínimas condições de comprar uma fralda, imagina um medicamento que o medico prescreve e não tem naquela unidade. $\mathrm{A}$ gente trabalha muito essa parte na sociologia.

(AEnf 02)

O enfermeiro é um educador. Nas questões sociais ele deveria ser em prol da educação, de estar prevenindo, de fazer o máximo que pode para evitar a doença. Esse seria um dever social. Tipo, fazer um projeto social com os adolescentes com as meninas que ficam grávidas muito cedo. É um dever social, fazer bem para a sociedade, diminuindo o índice de meninas que ficam grávidas, através de informações, de palestras, de cursos.

(AEnf 03)

Muitos profissionais não atuam no social pela sobrecarga de trabalho. Às vezes as pelas atividades que fazem esquecem-se de fazer alguma coisa pelo bem estar do ser humano.

(AEnf 05)

Há certa confusão nos conceitos de saúde coletiva do grupo de acadêmicas de Enfermagem. Na perspectiva de algumas acadêmicas entrevistadas a Saúde Coletiva restringe-se a atenção primária, a qual é caracterizada por ações de cunho preventivo. Dicotomizam a atenção preventiva da atenção primária e as ações curativas, as quais, segundo as acadêmicas, se dão em nível hospitalar e ambulatorial, demarcando que não entendem que possa acontecer atenção primária em nível ambulatorial. Neste trabalho do enfermeiro em Saúde Coletiva, que é restrito a atenção primária, há um processo de trabalho diferente em relação ao processo de trabalho em nível 
hospitalar, emblematizado pelo fato de que o enfermeiro em Saúde Coletiva não desempenhar seu trabalho paramentado como no hospital. 0 conhecimento necessário para a atuação em Saúde Coletiva é amplo e complexo, segundo as entrevistadas, na medida em que o profissional lidará com pacientes de todas as faixas etárias e em diferentes contextos, necessitando de conhecimentos pertinentes à bioestatística, infectologia, a vigilância sanitária, entre outros.

A saúde coletiva trata mais a atenção primaria, trabalha com a parte de prevenção e a hospitalar/ambulatorial é mais para o tratamento parte curativa da doença.

(AEnf 01)

Na Saúde Coletiva você vai atender a população mas também vai atender individualmente. A não ser quando você presta educação em saúde, que entra a prevenção. Mas geralmente o atendimento em si é feito individual.

(AEnf 04)

Na saúde coletiva o enfermeiro não precisa ser um enfermeiro de branco, mas tem que ser ético. Na saúde coletiva eles liberam mais essa coisa de uniforme calça jeans, tênis, porque vai lidar com a população, com a comunidade. A gente sai para procurar aquelas pessoas que estão doentes para trazer para atenção primária. Não precisa ter aquele uniforme todo branco, aquela coisa que deixa a população quando vê um médico e uma enfermeira. É o que diferencia a enfermeira da saúde coletiva da saúde do ambiente hospitalar.

(AEnf 03)

A saúde coletiva é uma área e um campo bem abrangente porque tem que saber de tudo. O enfermeiro vai ter que ter conhecimento desde a criancinha até o adulto, porque ele atende todos os programas de toda a população. Tem que saber da criança, tem que saber mais ou menos o peso adequado para cada idade, tem que estar preparado para atender uma mulher gestante tem que estar preparado, para atender uma paciente que vem com uma DST, tem que estar preparada para atender um idoso do programa de hipertensão e diabetes. Na Saúde coletiva se precisa ter muito conhecimento, conhecimento de todas as áreas. As pessoas sempre falam assim "ah, trabalhar na saúde publica é moleza vai lá, atende, depois vai embora". Mas quem fala isso não pensa que tem todas as 
estatísticas que tem que fazer todos os meses. O recurso principal é conhecer tudo desde a criança até o idoso.

(AEnf 02)

A enfermeira de Saúde Pública tem como característica fundamental o interesse pela saúde da comunidade, caracterizando grande interesse pelos outros, independente da remuneração, até mesmo por que a área é considerada a que menor retorno financeiro lega ao profissional. A necessidade de um amplo conhecimento sobre os diversos determinantes de saúde e as características tanto dos grupos populacionais, como das diversas patologias, é um requisito para a enfermeira de Saúde Pública. Outra característica é a capacidade de dialogicidade com os pacientes, sendo fundamental para a atenção à saúde na Saúde Coletiva.

O perfil daquela pessoa que é bastante interessado pelos outros, porque nossa área é onde ganha menos, é do enfermeiro que trabalha na Saúde Pública. Você exerce aquele trabalho do posto de saúde. Tem que ter esse perfil de prevenção mesmo, de ser 'pau pra toda obra'. Eu encaro assim: é aquela pessoa que é super líder, vai e faz acontecer.

(AEnf 03)

Para atuar na área de saúde coletiva você tem que estudar, tem que identificar com aquela área para fazer com amor. Acho que quando você faz um trabalho com amor, você faz muito bem.

(AEnf 03)

Durante todos esses estágios que eu passei vejo que estou preparada para o serviço publico, porque quando um paciente chega medroso eu consigo mudar essa situação, então eu acho que eu estou preparada para enfrentar qualquer tipo de paciente, mesmo no serviço público, que é bem conturbado em relação o atendimento.

(AEnf 01)

Para trabalhar em saúde coletiva o profissional tem que ter as noções básicas de saúde. Você não pode fugir a isso. No nosso caso de 
Enfermagem tem um limite para prescrever medicamentos padronizados.

(AEnf 01)

Em Saúde Coletiva o profissional tem que saber lidar com a população, tem que gostar de lidar com a população, porque se ele não gosta, não vai dar certo, ele não vai conseguir ser um bom profissional.

(AEnf 02)

Tem que saber ouvir a população, porque geralmente as pessoas gostam de conversar, você tem que saber cativar aquela população para que ela consiga fazer o que a gente quer. Você tem que ser convincente naquilo que está dizendo para que os problemas não venham futuramente. Tem que ter um perfil um perfil especifico para trabalhar com a população.

(AEnf 02)

Enquanto a atuação nos níveis de atenção à saúde secundária e terciária é prerrogativa dos enfermeiros que optam em lidar no cuidado individual e das patologias, a atuação no atenção primária está relacionado ao atendimento coletivo e preventivo. Ressalta-se, novamente, que as acadêmicas estabeleceram polarização entre Saúde Coletiva e ambulatório.

O perfil para trabalhar no hospital é gostar de cuidar das doenças

(AEnf 03)

Na Saúde coletiva o profissional tem que ter conhecimento para atender a população diferente do atendimento do consultório. Muitas vezes você não tem médico no local e tem também que improvisar porque não tem jeito.

(AEnf 04)

A área ambulatorial tem diferença para saúde publica por que nesta a gente trabalha muitas vezes com grupos, grupos da escola, grupo da comunidade. A questão é muito mais de prevenção mesmo. Já o atendimento ambulatorial não.

(AEnf 05) 
Diferenças entre o atendimento público e o privado são apresentadas pelas entrevistadas. Quando comparado ao serviço público, a iniciativa privada é caracterizada por um melhor atendimento na dependência do poder aquisitivo do paciente, rapidez, recursos humanos e estruturais melhores, não havendo falta de materiais como no serviço público.

Existem diferenças entre $o$ atendimento publico e o atendimento privado. No atendimento privado você chega e é bem recepcionado dependendo do poder econômico que você tem, dependendo do plano. Já no publico você vai ter que esperar horas e horas até ser atendido. Pode até acontecer alguma coisa até você ser atendido.

(AEnf 01)

O cenário é diferente entre o profissional que trabalha na área publica e o que trabalha no setor privado. No atendimento particular o atendimento é muito melhor em questão de medicação, de recursos. Quando ao ganho financeiro a diferença é gritante.

(AEnf 05)

No serviço privado com certeza o paciente é muito bem atendido e o profissional nos trata com bastante humanização, nos trata com respeito, nos ouve. Agora nos ambulatórios da parte publica é diferente, porque é como todo mundo fala. 0 paciente senta e o médico mal pergunta o nome e já vai prescrevendo.

(AEnf 02)

Meu estágio foi todo feito em instituições publicas. A gente já sabe como as coisas acontecem, como proceder nas dificuldades que muitas vezes a gente tem. No hospital que a gente estagia não tinha nem ambulância e é um hospital grande, atende a população até em neuro-cirurgia. No serviço publico falta de material, falta de profissional.

(AEnf 04)

Uma perspectiva sobre o assunto que chama a atenção é a debatida pela acadêmica de Enfermagem 04, para a qual existem sérios e profundos problemas de Saúde no Brasil, tanto no setor publico como no setor privado, que mercantiliza o 
serviço e que, por estar atrelado exclusivamente a questão do retorno financeiro, não prioriza as necessidades do paciente, podendo ser pior que o serviço público em determinados aspectos.

Em hospital privado é mais difícil você pedir um exame. Só autorizam em último caso. $O$ atendimento privado muitas vezes é pior do que o atendimento publico. A situação de saúde em si no Brasil esta cada vez mais precária.

(AEnf 04)

Seguem-se as sínteses dos produtos do grupo focal e das entrevistas individuais com discentes do curso de Enfermagem. 
Quadro 7: síntese das perspectivas apresentadas por acadêmicos do último período do curso de Enfermagem sobre o modelo pedagógico do curso

\begin{tabular}{|c|c|c|}
\hline Produto do Grupo Focal & Informações nas entrevistas semi-estuturadas & Convergências \\
\hline $\begin{array}{l}\text { Núcleo Temático 1: O modelo } \\
\text { pedagógico no ensino da } \\
\text { profissão } \\
\text { presença verticalidade na } \\
\text { relação aluno-professor } \\
\text { nos estágios } \\
\text { supervisionados } \\
\text { relação desgastante entre } \\
\text { professor e aluno } \\
\text { ausência de autonomia } \\
\text { do aluno } \\
\text { fundamental: aprender } \\
\text { fazendo } \\
\text { avaliação e da atribuição } \\
\text { de notas no estágio: } \\
\text { instrumento silenciador } \\
\text { fragmentação dos temas } \\
\text { em disciplinas } \\
\text { dissociação da formação } \\
\text { em dois momentos: } \\
\text { teoria e prática }\end{array}$ & 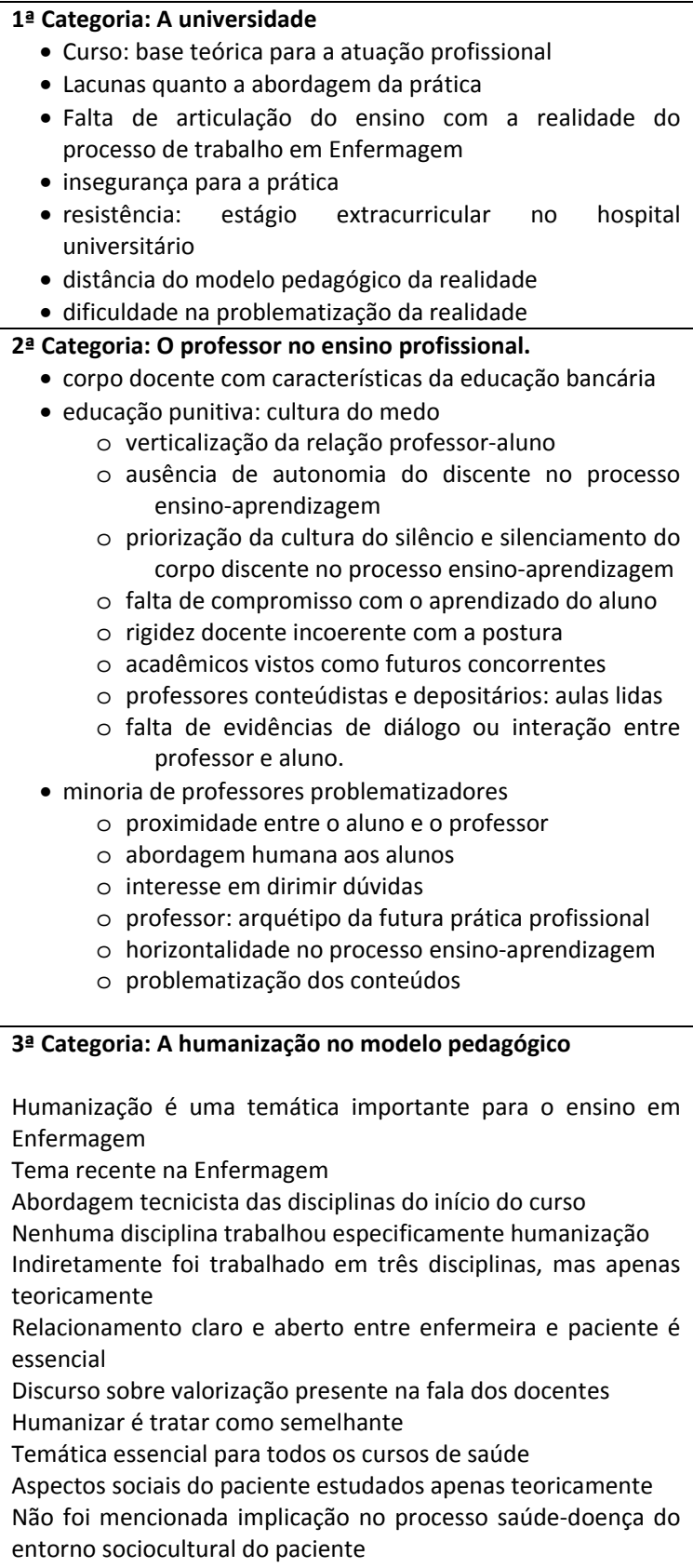 & $\begin{array}{l}\text { Há verticalidade do docente } \\
\text { no curso de Enfermagem, } \\
\text { caracterizando } \\
\text { predominância de educação } \\
\text { bancária, com características } \\
\text { relacionadas tanto a postura } \\
\text { dos docentes, como da } \\
\text { estrutura curricular, de forma } \\
\text { que o AEnf vivencia um } \\
\text { processo ensino- } \\
\text { aprendizagem em grande } \\
\text { medida verticalizado e em } \\
\text { que o enfermeiro é } \\
\text { construído em etapas } \\
\text { fragmentadas entre a teoria } \\
\text { e a prática. Este ensino é } \\
\text { desarticulado com realidade } \\
\text { que os futuros enfermeiros } \\
\text { vivenciarão. Neste contexto, } \\
\text { não existem medidas } \\
\text { educacionais pautadas na } \\
\text { humanização dos futuros } \\
\text { profissionais, quadro } \\
\text { agudizado pelo fato de que o } \\
\text { acadêmico não é entendido } \\
\text { no processo ensino- } \\
\text { aprendizagem como um ser } \\
\text { humano complexo, histórico } \\
\text { e social pelo docente, }\end{array}$ \\
\hline
\end{tabular}


Quadro 08: síntese das perspectivas apresentadas por acadêmicos do último período do curso de Enfermagem sobre o enfermeiro

\begin{tabular}{|c|c|c|}
\hline Produto do Grupo Focal & Informações nas entrevistas semi-estuturadas & Convergências \\
\hline $\begin{array}{l}\text { Núcleo Temático 2: O ser } \\
\text { profissional } \\
\text { - curso vinculado a uma } \\
\text { instituição pública federal } \\
\text { - bom mercado de trabalho } \\
\text { - influência de familiares } \\
\text { - carreira ser da área e o } \\
\text { trabalho no setor da } \\
\text { saúde } \\
\text { - relacionamento entre a } \\
\text { profissão e o cuidar } \\
\text { - trabalho de Enfermagem } \\
\text { como um ato de doar-se } \\
\text { - humanização significando } \\
\text { se colocar no lugar do } \\
\text { outro } \\
\text { - humanizar é tratar do } \\
\text { paciente como um ente } \\
\text { querido para estas } \\
\text { acadêmicas. } \\
\text { - Humanização é respeito } \\
\text { aos componentes do } \\
\text { paciente como um ser } \\
\text { humano complexo } \\
\text { - humanização } \\
\text { essencialmente } \\
\text { relacionado à prática } \\
\text { de Enfermagem. }\end{array}$ & $\begin{array}{l}\text { 4a Categoria: A humanização na prática do profissional. } \\
\text { - Humanização como sinomino de acolhimento } \\
\text { - Vínculo entre o profissional de saúde e o paciente é } \\
\text { requisito na prática humanizada } \\
\text { - Função do profissional de saúde: não relacionadas } \\
\text { estritamente a patologia } \\
\text { - Postura individual quanto a humanização decorre de } \\
\text { fatores relacionados a história pessoal dos profissionais de } \\
\text { saúde } \\
\text { - Ato de Enfermagem: desde atenção emocional até } \\
\text { questões biológicas } \\
\text { - simpatia entre o paciente e o profissional favorece os } \\
\text { primeiros } \\
\text { - há pacientes em que o profissional se apega mais e outros } \\
\text { que ele se apega menos, ou não se apega } \\
\text { - Estar na condição de paciente: situação de dificuldade, } \\
\text { indesejosa e fragilizadora do ser humano } \\
\text { - troca entre o profissional e o paciente: primeiro como } \\
\text { prestador de serviços de saúde e o último encontra-se em } \\
\text { necessidade } \\
\text { - o lidar com pacientes ocasiona mudanças nos profissionais } \\
\text { em nível pessoal } \\
\text { - Existência de complexidade nos determinantes de saúde, } \\
\text { que acompanha o paciente. } \\
\text { - o paciente é um ser humano, que se relaciona com outros } \\
\text { seres humanos, que está vinculado a um modo de } \\
\text { produção capitalista em que os fatores socioeconômicos } \\
\text { apresentam interferência direta na vida (entorno sócio- } \\
\text { cultural) } \\
\text { - Questões pragmáticas: foco do profissional na atenção, } \\
\text { distante do entorno sócio-cultural }\end{array}$ & $\begin{array}{l}\text { O enfermeiro é um } \\
\text { profissional de saúde, que } \\
\text { tem seu exercício profissional } \\
\text { caracterizado pelo cuidar do } \\
\text { ser humano em termos de } \\
\text { saúde. Não se trata apenas } \\
\text { do cuidar no sentido } \\
\text { biológico, mas também no } \\
\text { acompanhamento emocional } \\
\text { de pacientes que, por } \\
\text { estarem no serviço de saúde, } \\
\text { estão fragilizados. No } \\
\text { entanto, o Sistema de Saúde, } \\
\text { por suas características e } \\
\text { pelo processo de trabalho do } \\
\text { enfermeiro, torna difícil a } \\
\text { abordagem do paciente de } \\
\text { maneira humanizada, que é } \\
\text { caracterizada pela atenção } \\
\text { integral as dimensões } \\
\text { complexas do paciente e não } \\
\text { apenas a dimensão biológica } \\
\text { e reducionista, além da } \\
\text { postura do profissional como } \\
\text { um semelhante do paciente. }\end{array}$ \\
\hline
\end{tabular}


Quadro 9: Síntese das perspectivas apresentadas por acadêmicos do último período do curso de Enfermagem sobre aspectos do trabalho do enfermeiro e seu relacionamento com o paciente

\begin{tabular}{|c|c|c|}
\hline Produto do Grupo Focal & Informações entrevistas semi-estuturadas & Convergências \\
\hline 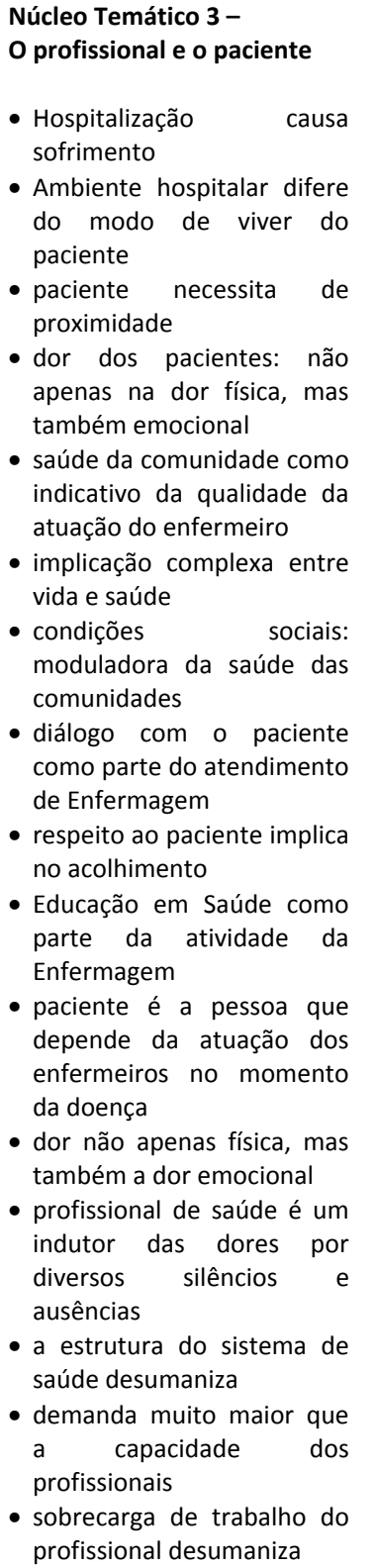 & $\begin{array}{l}\text { 6a Categoria: Ética, direitos e deveres do paciente } \\
\text { - Ética: forma valorização do ser humano } \\
\text { - Ética: leis que regulamentam as posturas no } \\
\text { atendimento em saúde } \\
\text { - Ética: fator implícito ao atendimento em saúde } \\
\text { - Ética protege o ser humano que está sob os cuidados } \\
\text { do enfermeiro } \\
\text { - Questões éticas são transversais a todo o serviço de } \\
\text { saúde e não deixam de estar presentes em nenhuma } \\
\text { área deste setor de serviços } \\
\text { - Principal função da ética: servir como instrumento } \\
\text { regulatório das ações dos enfermeiros } \\
\text { - Sem a ética seria instaurado o caos } \\
\text { - Ética que regula os limites da Enfermagem com relação } \\
\text { às outras profissões de saúde } \\
\text { - observância do sigilo e da preservação da } \\
\text { intimidade/privacidade do paciente } \\
\text { - presença do acompanhante no ato clínico } \\
\text { - diálogo aberto e claro para o esclarecimento sobre a } \\
\text { situação da saúde do paciente } \\
\text { - consulta ao paciente sobre se este se sujeitará ou não } \\
\text { a conduta } \\
\text { - pacientes não deveriam discutir com o profissional } \\
\text { - processo por desacato ao servidor público ou dispensa } \\
\text { do atendimento: punição ao paciente }\end{array}$ & $\begin{array}{l}\text { O enfermeiro é um profissional } \\
\text { que lida com a dor de origem } \\
\text { biológica, mas também com a dor } \\
\text { emocional dos pacientes. O } \\
\text { estresse do enfermeiro é } \\
\text { característico no ambiente } \\
\text { hospitalar pelas peculiaridades } \\
\text { deste serviço. Estresse é um fator } \\
\text { que inibe o enfermeiro em } \\
\text { relação ao tratamento } \\
\text { humanizado. A hospitalização é } \\
\text { um momento de sofrimento aos } \\
\text { pacientes, não apenas pelo } \\
\text { aspecto da doença em si mas } \\
\text { também pelas características do } \\
\text { ambiente que difere } \\
\text { substancialmente do ambiente } \\
\text { de seu cotidiano. Também a } \\
\text { grande demanda de } \\
\text { atendimentos também origina } \\
\text { atenção desumanizada, dada a } \\
\text { sobrecarga do enfermeiro. A } \\
\text { ética é reguladora do lidar com o } \\
\text { paciente pelo enfermeiro. }\end{array}$ \\
\hline
\end{tabular}


Quadro 10: Síntese das perspectivas apresentadas por acadêmicos do último período do curso de Enfermagem sobre aspectos do trabalho do enfermeiro nos serviços de saúde

\begin{tabular}{|c|c|c|}
\hline $\begin{array}{c}\text { Produto do Grupo } \\
\text { Focal }\end{array}$ & Informações nas entrevistas semi-estuturadas & Convergências \\
\hline $\begin{array}{l}\text { Núcleo Temático 4: } \\
\text { O profissional e o trabalho } \\
\text { em saúde } \\
\text { - Componente da } \\
\text { humanização: tempo } \\
\text { que o paciente junto } \\
\text { aos enfermeiros e } \\
\text { equipe de Enfermagem, } \\
\text { o é que dificultado pela } \\
\text { demanda } \\
\text { - Enfermeiro mais junto } \\
\text { ao paciente que os } \\
\text { demais profissionais da } \\
\text { saúde } \\
\text { - Enfermeiro como líder } \\
\text { da equipe de saúde } \\
\text { - Sentimento de baixa } \\
\text { valorização } \\
\text { Enfermagem frente aos } \\
\text { demais profissionais } \\
\text { - Existência de disputas } \\
\text { por espaço e conflitos } \\
\text { entre os médicos e os } \\
\text { enfermeiros } \\
\text { ificuldades do trabalho } \\
\text { em equipe de saúde }\end{array}$ & $\begin{array}{l}\text { 7a Categoria: A prática profissional e saúde coletiva } \\
\text { - é necessário que enfermeiro se articule com os diversos } \\
\text { setores da sociedade } \\
\text { - enfermeiro se propor a realizar ações de saúde } \\
\text { - muitas vezes a realidade do paciente não permite que tenha } \\
\text { condiçães de seguir o que é preconizado pelos profissionais } \\
\text { de saúde } \\
\text { - disciplina de sociologia: trabalho nestes conceitos } \\
\text { - Educação em saúde: eminentemente relacionada à } \\
\text { prevenção de doenças } \\
\text { - Sobrecarga de trabalho nos serviços de saúde justifica a não } \\
\text { atuação em relação ao entorno social do paciente } \\
\text { - Confusão nos conceitos de saúde coletiva } \\
\text { - Saúde Coletiva se restringe a Atenção Primária a qual é } \\
\text { caracterizada por ações de cunho preventivo } \\
\text { - Ambulatório não é entendido como atenção primária } \\
\text { - Dicotomia: atenção preventiva na atenção primária e as } \\
\text { ações curativas em nivel hospitalar e ambulatorial } \\
\text { - Enfermeiro em Saúde Coletiva: processo de trabalho } \\
\text { diferente em relação ao processo de trabalho em nível } \\
\text { hospitalar } \\
\text { - Enfermeiro em saúde coletiva não desempenha seu trabalho } \\
\text { paramentado como no hospital } \\
\text { - Conhecimento necessário para Saúde Coletiva: é amplo e } \\
\text { complexo } \\
\text { - Enfermeira de Saúde Pública: interesse pela saúde da } \\
\text { comunidade } \\
\text { - área é considerada de menor retorno financeiro ao } \\
\text { profissional } \\
\text { - Necessidade de conhecimento sobre os diversos } \\
\text { determinantes de saúde e as características tanto dos } \\
\text { grupos populacionais como das diversas patologias } \\
\text { - Níveis de Atenção Secundário e Terciário: cuidado individual } \\
\text { - Nível de Atenção Primário: atendimento coletivo e } \\
\text { preventivo } \\
\text { - initiva privada: melhor atendimento, rapidez, recursos } \\
\text { materiais como no serviço público } \\
\text { necessidades do paciente, podendo ser pior que o serviço } \\
\text { público em determinados aspectos }\end{array}$ & $\begin{array}{l}\text { O atendimento no serviço } \\
\text { público de saúde tem fatores } \\
\text { desumanizadores, tais como a } \\
\text { grande demanda por } \\
\text { atendimento, que não permite } \\
\text { ao profissional o devido tempo } \\
\text { para atender de forma } \\
\text { humanizada. O enfermeiro é o } \\
\text { profissional que mais próximo } \\
\text { está dos pacientes. O trabalho } \\
\text { em Saúde Pública exige } \\
\text { conhecimento do entorno } \\
\text { sócio-cultural do paciente e } \\
\text { atuação integrada junto a } \\
\text { outros profissionais de outros } \\
\text { setores. }\end{array}$ \\
\hline
\end{tabular}




\subsection{A perspectiva dos acadêmicos de Medicina}

\subsubsection{O produto do Grupo focal de acadêmicos de Medicina}

\subsubsection{Núcleo Temático 1: Sobre o modelo pedagógico no ensino de Medicina}

Com relação a vivência do modelo pedagógico na formação universitária médica, o grupo de acadêmicos de Medicina aponta que a desumanização do atendimento a pacientes observada no ambiente universitário, implica na construção de profissionais de certa forma desumanizados. Nesse processo, a postura dos professores de Medicina é aludida como moduladora da postura dos futuros médicos.

A parcela de culpa é dividida entre nós (referindo-se aos acadêmicos), os médicos e a própria formação universitária.

Quando a gente faz estágio no P.A. (Pronto Atendimento) ou no Hospital Tropical, quando a gente vai evoluir nossos pacientes a gente não trata ele como se fosse gente, "ah... é o senhor Raimundo..", você só fala... por que isso já tradição... paciente do leito 79 ... paciente do leito $43 . .$. né? Isso já é uma coisa que já vem de antes... Então, quando a gente fala: "oh, o seu fulano, ele ta assim, ele ta precisando desses cuidados, ele ta precisando de tal medicação", ele é paciente.

Não é uma coisa que é imposta, uma coisa só de agora. É uma coisa que já vem de anos e anos. É falho. Quem nos ensinou é falho. A gente teve aula de ética médica, é muito bonito (com deboche): "olha... você tem que tratar o paciente assim, assim, assim", só que. É o que você aprende na prática. Por o sistema não ta nem ai... não tem aquele negócio de "oi... e ai? Como é que o senhor ta?" O nosso sistema, os hospitais, seus sistemas de plantões... quando você chega você tem que saber a vida da pessoa em cinco minutos pra poder prescrever, pra poder evoluir, e tal... é muito complicado tudo isso.

Acho que você acaba herdando os vícios de seus professores.

A gente convive infelizmente com profissionais ruins e que passam estes vícios pra gente. E se você não ficar atento, se você não tiver um ponto de referência, você cai nessa. 
A gente teve exemplo de médicos grossos no próprio curso de Medicina, que tratam mal, que não pedem nada, que só mandam. Isso na cirurgia é comum, né? Tem cirurgião que não sabe pedir um favor, ele só manda. É o caso de cada um ter essa consciência. Por isso que você ir pro hospital desde cedo tem seu lado positivo e seu lado negativo.

Você começa a conviver e aprender os vícios dos outros. E você ainda ta muito imaturo na profissão. Até por que você ainda não é médico e se ele (o profissional formado) ta falando. Você não tem senso crítico. E tem até que ter cuidado com a ética, por que tinha muita coisa que eu via de errado e que eu não podia falar e não falo até hoje. É que eu sou ético. Mas eu vi muita coisa errada. Mas também via muita gente que fazia coisa certa. Então, quando você vai se meter na Medicina você tem que acompanhar sempre os melhores e sempre acreditar que, mesmo os melhores, eles vão falhar em determinado momento.

Você tem que ter vários pontos de referências. Tem que ter uma formação na cabeça, um ideal na mente e usar vários eventos e só tirar o melhor. Querendo ou não, quando você se formar, você vai agir da maneira que você achar certo. É da sua personalidade. Mas tem muita gente ruim. A gente tem que prestar atenção.

Com relação a conceituação do que é saúde, os acadêmicos de Medicina demonstraram dificuldade em manter debate mais aprofundado.

É o que a gente já disse...

É o bem estar físico, psíquico e social... não apenas a ausência de doença.

Melhor: algo mais que a simples ausência de doença.

Estudamos o conceito da Organização Mundial de Saúde.

Estudamos que saúde é o bem estar físico, psíquico e social... sobre ser profissional de saúde acho que não. A gente vê isso muito indiretamente, nas diversas disciplinas. Por que a saúde é modulada por todos os fatores. Mas a gente não viu isso em alguma disciplina específica. Talvez um pouco em Psicologia Médica.

Faltou muita formação neste sentido. 
A experiência prévia ao ingresso no curso de graduação, com médicos que não se mostraram sensíveis aos problemas dos pacientes, apresentou-se como momento pedagógico importante para a humanização destes acadêmicos.

É assim: uma coisa eu tenho certeza que esse lado ruim do médico, que os outros médicos me fizeram ver, já que já fui paciente, serviu para eu ver que eu nunca devo tratar as pessoas assim. (...) Depois que eles (os médicos) me fizeram ver o lado de eu ser a paciente, que é difícil você chegar pra uma pessoa e dizer o que ela tem... é lógico que me tornou mais humanizada. Então, eu vejo assim. Eu vou tentar fazer o melhor. Lógico, da forma contrária a que eu vi um dia.

A questão da postura pessoal humanizada, anterior ao ingresso no curso de graduação, emergiu no grupo como um fator muito mais implicado na postura do futuro profissional humanizado do que a vivência que estes acadêmicos tiveram durante seu curso de graduação.

Acho que a postura é individual. Se a gente depender do curso [de graduação] para mudar a cabeça, a gente não vai mudar.

O modelo pedagógico do curso de Medicina foi apresentado com talhe centrado na formação individualista do médico. A necessidade de buscar por si só a complementação necessária aos conteúdos trabalhados na universidade, para a completude da formação pessoal, além da questão da fragmentação da formação em especialidades não articuladas de forma interdisciplinar, são indícios desta priorização pela formação individualista. 
A abordagem do curso de Medicina é individualista. Tanto é que a gente entra na questão do currículo. A faculdade esta aqui. Mas você tem que ter 'um a mais'. Você tem que fazer sua parte por você mesmo. 'Ah... Você tem esse... Esse tal detalhe... '. Depende do nosso próprio esforço... Não só do curso.

Existem colegas da gente, até uma colega nossa que, hoje é residente e que a gente ouve sobre ela 'ah, ela esta na ortopedia. Vai abandonar a Medicina... ' Eles não são os únicos... A gente vê essa desunião... "Ah"... Ele é geral'... Ele é clínico geral... Então ele não sabe de nada... Ele é cirurgião? Cirurgião não sabe de nada...' Acho que isso é esta na origem e na formação das idéias... Também é claro que é uma questão individual.

O contato com o hospital durante os estágios iniciais da formação do acadêmico foi apontado como negativo, no aspecto da formação humanizadora, principalmente pelo convívio com profissionais e práticas não humanizadas.

Desde o início [do curso] eu achei isso um ponto falho. Eu sempre fui para o hospital e não tive qualquer preparação para o tratamento humanizado.

O contato prévio com o hospital é bom, mas se vê muita coisa errada lá também.

Se você não for conhecendo as coisas por si só, prejudica o convívio no hospital... Muito ajuda e muito atrapalha... Você vê muita coisa errada também... Se você não tiver personalidade você acaba se desumanizando.

A importância do Modelo universitário em Medicina na formação do perfil do

futuro profissional foi apontada pelo grupo.

A universidade molda que seremos. Eu era bem diferente quando entrei [no curso de Medicina], de como eu estou saindo. Eu acho que dá uma mudança sim. 
A presença de disciplinas humanizadoras na matriz do curso de Medicina foi apresentada como dissociadas da prática e, por isso, não atraem o interesse para os acadêmicos tanto por serem "conteudistas" como pela falta de maturidade do próprio grupo de acadêmicos.

[Com relação à disciplinas que trabalhassem o entendimento do ser humano] Tivemos história da Medicina.... Psicologia Médica... apenas estas e ainda de maneira superficial....

Estas disciplinas acabam sendo muito conceituais, de pouca aplicação prática...

Mais uma vez depende do aluno. $\mathrm{E}$ acho que os alunos normalmente não têm muito interesse. A maioria não... acaba até, então, nesse caso, que o professor se desestimula... 'Pra que ter uma matéria dessas, já que o aluno prefere estudar fisiologia?'.

Os alunos não ligam pra estudar este tipo de matéria. Falta maturidade.

A verticalidade na relação com os alunos durante o curso de graduação por parte de professores do curso de Medicina foi apresentada como um fator negativo, já que não possibilita a proximidade necessária para que o aluno resolva suas dúvidas. Também se fez diferença entre professores que ministram aula e professores que ensinam, sendo que estes últimos apresentam uma postura horizontal com relação aos seus alunos.

A gente não pode generalizar, mas tem alguns professores que... a maioria é, hierárquica em relação ao aluno.

Tem alguns que você fica até com medo de perguntar alguma coisa. Você fica até com medo, de perguntar uma coisa que é simples que poderia conversar com ele num bate-papo, de confiança... e tal... $O$ professor hierárquico não. 
Se a relação não fosse hierárquica, você poderia perguntar pra ele... Informalmente... E nunca mais se preocupar... Mas existe certo descaso por parte dos professores...

A gente sente assim como se ele tivesse ali dando aquela aula por que tem que estar lá, não ta a fim de fazê-la. Ele não ta ensinando. Ele ta dando a aula dele. Não ta ensinando.

Tem professor que não dá só a aula dele. Ele dá a aula dele e ele quer o resultado. Todo dia prepara uma aula um pouco diferente. Mesmo que ele não converse comigo, mas só dele preparar uma coisa lá, de eu ver que ele se atualizou... A aula...

Se você pega o mesmo professor, que te deu aula na sala-de-aula e você o pega em um plantão, ele tem postura diferente. Você vai lá e ele te dá muito mais atenção, ele te explica o que ele ta fazendo. Então, ai você percebe que ali ele ta te ensinando. Às vezes ele não te ensina também pela questão de horários. Ele está ali mais por obrigação. Quando você o pega em um horário mais tranqüilo

As vezes o superior dele manda ele dar uma aula... e ele não quer dar... e ele tem que dar a aula... ele dá de ma vontade, ou ele não está acostumado

Dá a aula não... Ele lê a aula...

Ele lê a aula... Derrama um monte de coisas... Vai tentar fazer com que os alunos absorvam aquilo... Fica faltando prática. Ele pode falar... Ler lá... Várias vezes... Mas sempre tem um que é melhor pra chamar a atenção [refere-se capacidade de motivar os alunos]... que é didático...

A postura verticalizada dos referidos docentes também se mostra no enfoque principal da transmissão/valorização de conteúdos, durante o processo ensinoaprendizagem, muito mais do que se o aluno aprendeu ou não os mesmos. Quando em dificuldade de aprendizado, os alunos devem buscar por si mesmos o conhecimento nas áreas deficientes ou que tenham duvidas, mesmo que tenham tido problemas no processo ou se este se mostrou insuficiente para construção de 
conhecimento sólido do futuro médico que, independente da universidade, deverá utilizar-se destes conhecimentos na prática diária.

No fim é o aluno que vai ter que correr atrás... Por que ele é quem vai ter que aplicar aquilo posteriormente

A gente não pode ficar dependendo da faculdade pra aprender... É mais com a gente, não é?

A gente que tem que ir atrás. Ninguém ta ai pra te ensinar. E isso [o conteúdo] é cobrado...

O conteúdo sempre aparece! E é cobrado! A gente faz prova... E o professor diz na sua frente 'não foi dado na aula, mas está no conteúdo'...

Às vezes eu saia da aula e não sabia nada. E o professor perguntava 'ué? Vocês não receberam essa aula? Ela está no programa de vocês... tem que saber...'

Se não teve aula, o que a maioria dos alunos faz é pegar o livro e ler... 'Não teve aula, vocês deveriam ler no livro', diz o professor... O conteúdo é jogado pra gente... a gente que tem que correr atrás... ai o problema quem tem que corrigir é o aluno, que vai precisar do conhecimento no futuro.

A orientação claramente bancária, preponderante neste curso, evidencia-se quando se confrontam os depoimentos com os pressupostos freireanos ${ }^{35,36,79-88}$.

\subsubsection{Núcleo Temático 2: Sobre o ser Médico}

Assim como para os acadêmicos do curso de Enfermagem, para estes acadêmicos do curso de Medicina, a influência e o convívio com familiares médicos foram fatores que influenciaram na escolha pelo curso. 
As conversas em ambiente familiar foram muito voltadas pra Medicina. Se eu tivesse que escolher outra profissão no lugar da Medicina não teria outra.

Minha mãe era da área da saúde, é técnica, só que... lógico... não me influenciou... ai, como eu sou a mais nova lá de casa, minha irmã mais velhas é da área da saúde... é enfermeira... aquela roupa branca. (...) não tive como fugir do meu destino.

Tenho dois tios médicos, tios de primeiro grau, os outros tios, de segundo grau, também são médicos.

Uma perspectiva fortemente reincidente na fala dos acadêmicos de Medicina, com relação a sua escolha pelo curso, foi à possibilidade de ascensão social, manutenção de alto padrão econômico garantido pela prática profissional e o status que o profissional médico apresenta na sociedade. Também o fato da grande oportunidade de postos de trabalho mostrou importância demarcada para este grupo. Nesta questão da opção pela profissão em decorrência das características de seu mercado de trabalho, o médico foi apresentado como um profissional privilegiado pelos padrões de remuneração acima da média dos profissionais de saúde.

Além de eu gostar da Medicina, outro atrativo é que ela é um método de ascensão social, isso eu não posso negar... é uma boa área, com emprego, emprego garantido, além de eu achar uma área bonita.

Escolhi por ter interesse social. Eu não sabia se ia gostar ou não. Daí eu gostei, principalmente em relação a segurança social, de ter garantia de ter uma boa qualidade de vida.

Os critérios utilizados são status social, segurança financeira, lógico que é uma profissão que me preenche no lado pessoal. Acho que fica resumido nestes critérios mesmos, de ser daquelas áreas hoje mais visadas nos vestibulares mais concorridos, por estes motivos que eu já citei. Vai mais por esta linhagem mesmo. Mais do que uma vocação, ali cega... Caxias... não sou o tipo que sempre.... nasci pra 
fazer Medicina, nunca pensei em fazer outra coisa... Eu tive este dilema, mesmo... será que eu devo fazer Medicina... será que eu não devo fazer Direito... nunca entrei naquela questão da área.. eu sempre pensei, ou eu faço Direito ou eu faço Medicina... estes foram os dois cursos que realmente eu quis fazer. No final eu acabei escolhendo Medicina, pelo critério de achar o trabalho mais bonito, recompensador pelo lado pessoal mesmo. Financeiramente até se equivalem, e em status social... eu acho que era por ai.

Eu gostei muito da área. É uma área muito gratificante mesmo. A gente vê a pessoa entrando mal e saindo bem, digamos assim, neh? Sem contar em tudo o que os meninos já falaram, neh? Status, aquela segurança que te dá. Se bem que hoje em dia, quando a gente fala em segurança, a gente vê que não é tão bem assim, a gente vê que na questão de segurança é um emprego bom, a gente não vai negar, mas hoje em dia tem que ter "um algo a mais", tem que ser... tem que ser o melhor pra poder se manter.

A chance de emprego é boa em todos os lugares que a gente vai.

O médico é um prestador de serviços como outro qualquer, mas com maiores chances no mercado.

De forma dicotômica a esta perspectiva e, com certo tom de resposta a este posicionamento, alguns componentes do grupo de acadêmicos firmaram posição de que a atividade profissional médica tem um caráter que extrapola a mercantilização e a medicalização do atendimento, indicando uma atuação complexa e honrosa para a pessoa que exerce a atividade. Inclusive condenando a perspectiva mencionada anteriormente dos colegas.

Será que ser médico é apenas se formar em Medicina? Será que, ser médico, é apenas ter o diploma de bacharel de Medicina? Ou ser médico é muito além disso? Ser médico, ou seja, será que ser médico é apenas ser um técnico ou vai até ser um grande ser humano, capaz não só de curar mas também capaz de consolar, de afagar. (...)

Médico, quando a gente pensa na grandiosidade dessa palavra e na beleza da palavra... e existe o cara que se utiliza do conhecimento 
dele e da técnica dele, e pode ate faze-lo muito bem, mas tratando o ser humano como apenas um objeto de trabalho e não como um ser humano.

Como todas as profissões têm maus profissionais. Profissionais péssimos. Tem pessoas que não sabem trabalhar ou que trabalham ali por questões que não é a Medicina em sua essência.

Quando se entra no meio médico, é igualmente ao que o foi falado: você se decepciona muito por que você se depara com muita gente que não tem essa idéia, que não tem esse humanismo. Que não viva a Medicina. Ele não vive a Medicina. Ele se utiliza da Medicina. É o conceito que eu tenho. Também existem os grandes médicos, profissionais, médicos de caráter. Só que ai a gente também se depara com o inverso. Também aí a gente vê como a realidade é cruel: têm médicos que são muito bons tecnicamente, mas falhos no caráter; têm médicos que são até "gente boa", mas não chegam a... sei lá... a ser tão competentes. Ai está a questão. Quando você se depara com essa miscelânea, vamos dizer, de tipos de médicos que existem.

Existem pessoas formadas em Medicina que, talvez, você não o veja com o perfil de um médico. Mas é um cara que ta usando o conhecimento que ele adquiriu, a técnica que ele adquiriu mas ele, talvez, nem acabe sendo médico.

As vezes, o cara que é formado em informática, eu até entendo, ele ta tratando um computador como um software que, pronto, ele mexe. Agora como médico não. Você trabalha com o ser humano. Uma palavra que você deixa de dizer faz uma diferença muito grande até no curso da doença ou da vida desse próprio paciente.

(...) o outro colega mal olha, vê o que você fez pra medicar e o que aconteceu.

Esta perspectiva se reafirma em momentos em que se idealiza um tipo de médico, tal como o antigo médico de família, que, ao longo de toda a vida do indivíduo, o conhecia, aos seus progenitores e aos seus descendentes.

Muito antigamente existia aquele médico da família, o médico da família existiu há muito tempo atrás... o médico da família era o que o pai, o avo, o filho o procurava. Não era apenas o médico. Ele 
acabava fazendo parte da família. Ouvia a mulher, que falava do marido, e hoje não.

A responsabilidade da atividade profissional do médico foi aludida, na medida em que se está lidando com seres humanos, com suas vidas. Estas que são imbuídas de complexidade e o ato médico têm significados muito além da clínica.

O médico tem a responsabilidade realmente grande. Hoje eu tenho certeza que realmente é difícil, que é uma profissão complicada. Que você tem que gostar muito pra ser bom.

O médico é um profissional, ser humano como outro qualquer, que promove a saúde. Não apenas cura doença. Tanto quanto qualquer outro profissional da saúde. Não apenas o médico.

(Se faz saúde na vida das pessoas) De todos os modos... não só clinicamente. Com uma palavra, um gesto... as vezes só dando atenção, a gente já produz saúde na vida das pessoas.

Com a convivência no meio médico, os acadêmicos apontam que a postura não se dá como algo pronto ou totalmente modulado pela universidade, mas sim ressaltam que características pessoais influenciam na atuação médica.

No meu caso, eu mudei a visão que eu tinha da Medicina, desde o momento que a gente foi caminhando dentro do primeiro, segundo, terceiro período. Eu fui percebendo que quem faz a Medicina é o médico. Que tem o lado bom, tem o lado comunitário, tem o lado da atenção também. Tem tudo de bom, né? Se você fizer o melhor, você vai ser uma boa pessoa e um bom médico também.

Nas discussões, diversas definições de humanização emergiram. A principal reincidência referiu humanização como empatia, ou seja, o tratar do paciente como a 
si mesmo ou a um ente querido. Em outra perspectiva, humanizar tem o significado de não priorizar apenas a patologia, mas também outras dimensões, rumo a complexidade do processo saúde doença, apesar deste conceito chocar-se com o discurso pautado no modelo biomédico durante o atendimento clinico, registrado anteriormente.

É a ação que trate o paciente como semelhante.

Humanizar faz com que se trate como trataria sua mãe ou sua esposa.

Trate de ser humano pra ser humano. Infelizmente, sejam por características pessoais, sejam pelas falhas do sistema de saúde, grande parte dos médicos não agem assim.

[Humanizar é] não trata-lo como doença... sim como um humano, uma pessoa.

[Humanizar é] atentar para o que esta por trás daquela condição.

[Humanizar] É tratar mais do que a doença.

Você deve se colocar no lugar do paciente... Deve se transpor... Como se fosse um espelho, ali em sua frente...

Em polaridade dicotômica a este discurso de humanização pautada na empatia, o grupo aponta a humanização como estratégia para ganho de confiança do paciente para facilitar a intervenção médica, retomando o discurso monopolizador do conhecimento sobre saúde.

Humanizar é bom para ganhar a confiança. A gente tem que conquistar cada vez mais a confiança do paciente. $\mathrm{O}$ que a gente ta perdendo, o que a Medicina ta perdendo é a confiança. Hoje em dia você passa um remédio para o paciente e o paciente te olha "meio 
estranho"... "Porque ele não passou outro? E o antibiótico? Por que ele não botou antibiótico pra mim? Botou só analgésico?" Então, o que a gente ta perdendo é a confiança. Mas o que faz a Medicina perder a confiança são estes péssimos profissionais, que entram na Medicina pelo dinheiro.

[Humanizar] é você ganha-lo em seus problemas, em sua obrigação.

É ganhar a confiança do paciente. E como é que você ganha esta confiança? Mostrando que você está interessado nele, não só na doença dele, no que ele ta sentindo... Eu acho que é mais por ai... Você se torna mais humano quando você conversa com a mente do seu paciente. Claro que, no internato, a gente tinha uma folguinha e a gente ia lá ao leito conversar com o paciente. Às vezes tinha paciente que eu ia lá, levava uma palavra do que a gente ia fazer com ele. Mas é o tipo de coisa que eu ganhava ele. Eu já entrava e ele tava ali pra mim, já me cumprimentava. Então, era um paciente que se eu falasse pra ele pular três vezes que ele ia melhorar, ele pulava três vezes. Ele vai confiar mais em mim. E isso ajuda muito o tratamento. Ele adere mais ao tratamento.

Ao emergir o paradoxo da teorização e idealização da humanização confrontada com a prática clínica, o grupo se dividiu entre um posicionamento pragmático, no qual a humanização é tomada por uma utopia não realizável pelas características do sistema de saúde; e outro posicionamento em que o pragmatismo é condenado e não suplanta a necessidade de lidar com o ser humano como um ser humano, implicando em questões éticas do atendimento médico, inclusive sendo aludido que, para os médicos que não gostem de lidar com seres humanos, existem especialidades típicas dentro da própria Medicina que garantam o isolamento.

Neste setor da humanização, eu também acho complicado por que nem em todas as situações você vai poder trabalhar a humanização. Tem um amigo nosso que é cirurgião, dessas cooperativas que tem esquema de plantão, tinha um caso, ele contando, que chegou um paciente lá cortado, com facada, não sei o que... chegou lá todo 
nervoso, querendo bater no médico. Daí meu amigo deu uns "supapus" nele.

Eu não sei... Acho que tudo é questão do contexto. O cara trabalha pra caramba, se estressa, depois vem bêbado "botar banca", acho que não é questão de ser humanizado...

É a tal história: como ouvir e conhecer a vida de cada paciente se você tem que fazer trinta atendimentos por manhã?

Não concordo com um atendimento desumano seja em que contexto for.

Acho que pro cara chegar a ser médico e atender, seja em situação de normalidade ou sob a pressão de situação de emergência, tem que ter um controle emocional. Ou senão está na profissão errada.

São esses caras (médicos desumanizados) que estragam a imagem do médico...

Se não tem estabilidade emocional pra conviver em situação de estresse, procurasse outra especialidade ou outra profissão. A Medicina é riquíssima em campos, inclusive se ele não gosta de lidar com ser humano, fizesse imagenologia. Agora, ser cirurgião, lidar com vidas humanas, e sob estresse, pra depois bater em bêbado? Era melhor nem fazer. São esses os caras que tão afim só de grana e mancham a imagem da Medicina.

A contradição interna entre médicos mais humanizados e médicos com enfoque menos humanizado emergiu, mesmo no posicionamento deste grupo de acadêmicos, que revela a existência de ambas perspectivas no processo ensinoaprendizagem $^{35,36,79-88}$. 


\subsubsection{Núcleo Temático 3: Sobre a relação Médico-Paciente}

A ética da atuação do médico na ação clínica foi uma questão muito valorizada nas discussões, registrando-se que, apesar da ampla possibilidade da intervenção médica na vida do paciente, o limite deve ser pautado no conhecimento e no bom senso.

Se o paciente puder te dar total liberdade você vai ter plenos poderes sob o paciente? Acho que não é bem por ai. Acho que precisa ter, tipo, uma ética do próprio profissional médico.

Acho que o médico é capaz de ter que impor o limite ele mesmo, por que se não, se ele deixar, o paciente ultrapassa.

E olhando a maneira... uma resposta... mais técnica... tem a questão da especialização também... até onde vai teu conhecimento, onde tu tem que parar.

O limite do médico vai até onde o paciente permite.

O limite do médico é o bom senso.

Apesar da existência de profissionais médicos cujo enfoque principal na Medicina é o retorno financeiro, esta prática foi condenada dado a peculiaridade do médico lidar com a vida humana. Estes profissionais que destoam desta perspectiva são considerados incorretos por prejudicarem a imagem da Medicina frente a sua considerada real função. Os acadêmicos trazem ao debate a questão da necessidade de dedicar-se a Medicina por vocação e não por retorno financeiro, inclusive existindo momentos em que o exercício médico foi comparado a sacerdócio.

O que estraga a Medicina, o que faz a gente ter todo este bate papo que a gente está tendo agora é que tem gente que entra na 
Medicina pensando em dinheiro ou qualquer outra coisa que não seja realmente a Medicina, que é como foi falado: tratar as pessoas de maneira humanitária mesmo.

Se quer entrar na Medicina, entra pela Medicina em si, entra pelo "sacerdócio" da Medicina, pra ajudar. Por que tu vai conseguir assim ser o melhor e tu vai conseguir ganhar mais dinheiro do que qualquer outro. Se você entra na Medicina com essa mentalidade você vai se destacar, por que o médico que se destaca hoje em dia que tem esse lado solidário. Por que se não tem, ele vai ganhar dinheiro. Mas não vai ter o destaque. Ele nunca vai ser o melhor mesmo. Ele vai ser um médico.

Pra mim é uma profissão, que não é igual as outras. É uma profissão que é diferente, por lidar com a vida. Por lidar com a vida do ser humano. E por lidar com a vida do ser humano, já diferencia tudo. É uma coisa que você pode dar anos de vida pra uma pessoa ou pode mata-la em meses, dependendo de uma atitude. Medicina é muita responsabilidade e privação. A gente deixa de viver a nossa vida pra viver a dos outros.

Não adianta ter dinheiro, não adianta ter o melhor consultório, se você não atende bem. Por que a pessoa sai do seu consultório sem o elemento que veio procurar.

Esta perspectiva esteve relacionada à característica da atuação do médico na vida das pessoas com ampla influência, percebida pelos acadêmicos como extrapolando o limite das questões clínicas puramente. E que a ação do médico não se dá apenas pelas questões de procedimentos clínicos, mas também na intersubjetividade junto ao paciente.

Eu acho que é muito grande a atuação do médico na vida das pessoas.

Existem vários aspectos. Dependendo de onde você vai aplicar sua ciência.

Todos os aspectos competem ao médico, desde a vida sexual do paciente. 
Todos os tópicos da ficha de anamnese, como a gente chama, você conversa com o paciente sobre a história dele, a história psicológica, a história psicossocial, a história de familiares...

A história alimentar compete ao médico, por que interferem na saúde do paciente.

O desenvolvimento psicomotor... neuropsicomotor... está diretamente relacionado a saúde e são de interesse do médico.

Acho que entre o médico e o paciente não é... é lógico... entre aspas... não deve haver pudores pra que essa... pra que realmente se procure atingir a cura ou alívio.... tem que ter sinceridade.

Uma palavra que você fala... Você pode melhorar ou piorar a vida das pessoas. Ai é que falo da importância de um profissional que ouça, toque, sinta seu paciente...

Uma questão extremamente significativa que emergiu é a dor do paciente. Para estes acadêmicos, falar de dor é falar de descaso e de falta de dialogicidade entre pacientes e equipe de saúde, na medida em que o silêncio sobre as condições do paciente para o mesmo por parte dos profissionais é legar dor tanto quanto falar, dependendo da maneira com que se faça, pode também causar dor.

Pensar em dor é se colocar no lugar do paciente. É pensar que aquilo que a gente vai falar, fazer, vai causar.

Falar também causa dor ou diminui a dor.

O não falar também causa dor. A negligência, o descaso é a pior coisa, eu acho.

Às vezes o falar é mais importante do que aquilo que a gente prescreve.

Às vezes um paciente pode estar sendo tratado em enfermaria para determinada patologia e estar tudo certinha com ele, mas ninguém chega lá com ele e fala o que ele tem o que ta sendo feito. Se isso for uma doença crônica, grave, que vai se arrastando, ele fica um 
mês, dois meses sem saber o que estão fazendo, o que está acontecendo. Causando angustia [no paciente].

Às vezes ficam cinco meses, um ano... eu queria falar pra ele "olha, vai ser demorado... é só demorado, mas é uma coisa simples" e a gente acaba fazendo mal e não falando... O que vale é tentar dar o melhor de mim, não é?

Posso dar o melhor de mim... acho que só por essa conversa, por uma orientação.

Vou falar por mim: terminei recentemente um estágio e a gente sempre tem enfermaria de manhã... e tal.... e sempre gostava de todo dia, falar com o residente, ver o que foi feito, o que o paciente tem, o que não tem, pra eu sempre falar para o paciente. Eu tentava transmitir usando exemplos. A maioria [dos profissionais médicos] não fala. Mas eu sempre falava. Eu notava que quando eu chegava lá, o paciente ficava feliz, ansioso por saber o que eu ia falar. Se eu não falar, ninguém falava. $E$ eu notava que o paciente melhorava. $E$ o que eu lhe falava não era em termos de procedimentos que iriam ser realizados. Era apenas orientação. Só falava o que está sendo feito.

Deve se pensar que o paciente esta lá... sozinho e largado... é bacana dizer "poxa, eu to te vendo todo dia!"

É muito melhor você chegar dizendo "olha, eu sou o médico, vamos ter que tirar teu sangue, te tirar do leito, vamos te levar a sala de ressonância magnética... em seguida a gente volta para colher uma amostra de sangue" do que você já chegar e ir lá pra dentro.

É um dos tipos de dor: a dor do descaso!

Quando você fala com o paciente você supre aquela angústia daquele paciente... Ao menos ele fica sabendo... É melhor do que ele ficar todo angustiado... É evitar dor...

Falar significa ganhar a confiança do paciente... vem a papelada: o paciente 36 tem que mandar pro hospital 'não sei o que'... Quando você pegou e conversou com ele, o paciente pega mais confiança...

Com conceitos demarcados dentro do processo de trabalho do médico, o paciente foi definido por este grupo como um ser humano, semelhante complexo, que recorre ao profissional em casos de desvios em sua saúde. Há certa tendência para a 
vitimização do paciente, no sentindo de que este é um ser humano que precisa ser esclarecido com o conhecimento que o médico detém e que está posto a disposição do primeiro, caso se apresente para o ato clínico e intervenção do médico. Não junto ao médico. Um pensamento demasiadamente medicalizado, verticalizado e monopolizador quando pensado na interação paciente-profissional durante o processo terapêutico e do entendimento de que o processo saúde-doença não se dá exclusivamente por componentes biológicos.

Paciente é aquela pessoa que procura serviço médico precisando de algum auxílio quanto ao processo saúde-doença. E auxílio é qualquer coisa que entre nesta questão "saúde-doença".

Você pode ver nele desde uma coisa "simplesinha" até um caso mais complicado.

Ele pode chegar lá e perguntar de dor de cabeça dele, até coisas mais complicadas e coisas mais normais.

É um ser humano complexo.

Paciente é aquela pessoa que entra num consultório, num hospital, num serviço de saúde, à procura de melhoras, à procura de uma palavra amiga, à procura as vezes de esclarecimento. Então ele é um paciente, que precisa de... precisa ser esclarecido... Quando a gente fala "o paciente", a gente leva logo pro lado da doença. Mas não é culpa do paciente. Do paciente, a gente tem que primeiro saber que atrás daquela pessoa que ta ali esperando uma palavra, tem uma família, tem uma pessoa que ele toma conta, tem uma pessoa que toma conta dele, deve ter uma família, deve ter filha, deve ter mãe. Por trás do paciente você não aborda só ele. Você aborda todo o contexto social dele. Pêra aí! Se você teve, se você tem esta parasitose, vamos voltar um pouquinho atrás. Por que teve? Tem que ir à fundo, tem que saber como é a consciência, se a água que ele toma é de boa qualidade, se ele anda calçado.

É um outro ser humano que entrega a intimidade dele nas tuas mãos. 
Apesar desta visão ampla sobre a possibilidade de atuação do médico na vida dos pacientes, quando a discussão encaminhava-se para que questões mais pragmáticas e diuturnas da atuação profissional do médico, esta se apresentava enfocada exclusivamente em um conceito biomédico de saúde. Não que não houvesse a percepção da complexidade do processo saúde-doença na vida dos pacientes, mas esta compreensão não garantiu operacionalização destes conceitos na ação clínica médica.

Ser médico é dar o melhor de si para poder tornar uma pessoa melhor naquela patologia que ela tem, naquela doença que ela tem, e tentar fazer o melhor de você pra ela e pra família dela, bem nos esquemas de saúde.

Você tem que saber até a onde você ta sendo realmente eficiente.

Só com experiência você vai saber se aquilo que você vai fazer vai te auxiliar naquele processo, naquele diagnóstico, naquele tratamento.

Esse panorama se tornou mais evidente quando o debate encaminhava-se para as limitações sócio-econômicas da população brasileira, que foram apresentados como distantes da competência profissional e não pertinentes a considerações pelo médico quando em sua prática clínica, mas sim de responsabilidade de outros atores sociais e do Estado.

(...) Digamos que um médico atendeu uma paciente e passou um remédio pra ela e ai ela falou "doutor, eu não tenho dinheiro pra comprar". "Mas esse é o remédio que tu vai ter que tomar e na rede pública não tem. Tu vai ter que tomar esse. Daqui pra frente eu não posso mais fazer nada." E é uma atitude fria, mas é uma atitude verdadeira por que não tem como. O que ele falou foi "eu não posso, não tem como eu passar um remédio pra você que não vai 
curar sua filha". Eu acho que ali foi o limite. Até aqui é o meu trabalho. Daqui pra frente, se você não tem condições é por que o governo não ta funcionando, a prefeitura não ta funcionando. Ai o médio, infelizmente, tem suas mãos atadas. Então, tem o limite social também.

Mas não é tua obrigação, por que é obrigação do Estado, do governo federal, que aqui dentro tivesse um profissional qualificado para ver estas questões, que não o médico.

A condição socioeconômica do paciente foi apresentada como barreira para a atuação do médico, dado que, segundo os acadêmicos, os pacientes dos estratos sociais mais inferiores não conseguem seguir a prescrição médica, por falta de entendimento do que o profissional Ihes orienta.

A condição socioeconômica do paciente vai interferir no tratamento... Às vezes o paciente não consegue seguir uma orientação nossa. Então não tem como trata-lo...

Você fala dez vezes uma coisa e o paciente não entende.

É uma coisa que vem do paciente em si, por que ele não tem realmente como entender.

Você diz "três por dia"... ele toma tudo... toma errado.

Tu diz "repetir após vinte dias" e ele não sabe ainda.

Quando eu atendia um paciente, assim, de uma condição socioeconômica mais baixa, eu tentava chegar e dizer "e ai? Entendeu? Dois de manhã... dois à noite...".

Esta postura frente a dificuldade da sensibilização do paciente a seguir a conduta prescrita foi consenso junto a maioria dos acadêmicos. Paralelamente houve manifestação de que a questão não pode ser entendida de maneira reducionista e que 
retrata um panorama complexo em que a culpabilidade não recai sobre o paciente, mas sim em questões de fundo societário.

Não concordo que o paciente seja culpado disso. Não adianta a gente dizer pra ele ter gasto, se ele não tem nem fogão... O gasto que ele tem lá mal dá pro... Pra vida... Às vezes não dá pra um leite, que dirá. Ele chega na sua casa, que não tem forro. Ai depois você dá um remédio pra ele, ai ele esquece de usar às vezes. Eu acho que "rola" um preconceito... Não é por que... Eu acho que não é a compreensão... Acho que é mais a questão social... Eu acho que dá pra ajudar de outras formas

A resposta do grupo a este posicionamento antagônico de parte dos integrantes encaminhou para o entendimento de que este pensamento é pautado em assistencialismo.

Acho muito complicado entender as coisas dessa forma. Os problemas existem e você não pode dar dinheiro para todo paciente que for atrás. É inviável esta condição...

Em particular, a questão da Educação em saúde que incide diretamente nos conceitos debatidos anteriormente, trouxe nova polarização no grupo. Algumas falas apontam Educação para Saúde como medida relacionada à prevenção e não integrada na prática clínica do médico, justificando, inclusive, que o paciente, ao procurar o profissional, prioriza o atendimento emergencial. Ao mesmo tempo, a atuação médica frente a vida do paciente, que é complexa, e a influência do profissional além das questões puramente relacionadas a clínica, foram justificativas tanto para a importância como para a adequação da Educação para Saúde à ação do médico. 
Educação em saúde faz mais parte da questão preventiva... a gente vê que as pessoas... [enfatiza-se] mais quando a gente vai divulgar, fizer palestra e coisa e tal... a gente vê que as pessoas, quando é novidade, vêm que é novidade e mudam um pouco a concepção das coisas. Na prática clínica eu acho difícil.

Acho que na prática é um pouco difícil, por que ele [o paciente] vai pro consultório querendo resolutividade, ele não quer saber de prevenção. Prevenção, eu acho, tem que ser fora do hospital. Mesmo quanto a orientação, alguns [pacientes] querem, outros não. Você tem que ter paciência para isso... Não dá pra fazer isso no CAIC [Centro de Atendimento Integral à Criança da Prefeitura Municipal de Manaus - Amazonas] que você tem que atender vinte e quatro pacientes em um determinado período de tempo. É complicado fazer educação sob esta pressão.

Educação em Saúde é mais explicar direito pro paciente como usar o remédio que a gente prescreve.

Não. Não é só a questão de explicar... As pessoas não vão especificamente querendo um remédio... Querem uma palavra... é ai que está a questão. A nossa parcela de dificuldades já vai ter que partir daí. Fazê-lo entender que ali, ele não vai buscar só o remédio... Acredito ser possível Educar em Saúde quando você tiver frente a frente com seu paciente, se tiver disponibilidade para isso, ai sim.

O médico deveria ser um profissional para a saúde. Mas muitas vezes não é. Se entendido como algo mais amplo, que interfere na vida das pessoas, muitos exercem a Medicina, mas não fazem Medicina.

A questão do monopólio médico do saber sobre saúde emerge novamente, na medida em que a questão da necessidade da população reincide, dentro de um pensamento verticalizado no atender da população em geral, reafirmando a perspectiva de que os médicos detêm o conhecimento do que é ou não problema de saúde e que os usuários, por sua vez, apresentam-se para o atendimento com queixas infundadas e relacionadas à sintomatologia. Justificam a superficialidade no atendimento também pela grande demanda. 
A necessidade depende da população por que, por exemplo, a população carente não quer saber de atendimento, quer saber logo de medicamento: 'eu to com isso... quero logo isso... ah doutor... passa uma pomada... passa antibiótico...' então depende muito.

Às vezes é uma população... Onde as pessoas carentes são sintomáticas. Ela chega lá por dor. Ela não está preocupada com o que ocasiona aquela dor. Ela quer que tu sanes a dor... Às vezes o médico, por comodismo, acaba entrando neste sistema também. Por que ele chega lá e o paciente 'ah, estou com dor'. Ai ele chega lá, e prescreve uma Dipirona. A dor passou, o médico vai embora. $\mathrm{O}$ paciente não.

É ai que eu te digo que a questão entra no Sistema... Como tu tem muita gente pra atender, o simples fato de tu ter passado o remédio que vai sanar a dor e tu já ta sabendo que o paciente ta satisfeito com aquilo por mais que, na realidade, tu não tenha resolvido o problema dele, tu acaba despertando pra entender: tu tens mais 25 pra atender.

Como o médico tem que pensar não só na dor? O que ele pode fazer? Tem mais pacientes para atender do que deveria.

As necessidades são várias, mas aquilo que mais chama a atenção é o que o paciente vai atrás, vamos dizer... É isso: o atendimento curativo.

A necessidade seria geral... Em qualquer aspecto... Mas eu digo, na questão da necessidade, não que a população tem, mas que ela acha que tem... Por que é essa necessidade que ela acha que tem que faz ela te procurar... Se eu falo a necessidade da população é a necessidade partindo dela para gente, não da gente para ela.

Apesar de, novamente, a questão da postura pessoal frente ao atendimento do paciente ser referida, o grupo apresenta que a demanda pelo atendimento no Serviço de saúde não permite que o médico atenda de maneira humanizada, dado o pouco tempo e o grande número de pessoas a serem atendidas. $O$ atendimento focado na sintomatologia dolorosa novamente surge, agora não como o pensamento infundado dos pacientes como anteriormente, mas sim como o critério de priorização de atendimentos. 
No pronto atendimento a gente atende muito mesmo. Mas, assim, no meu caso, um posicionamento pessoal mesmo, eu acho que não vai mudar muito do que eu já fiz até hoje. Nem, que o ambiente seja muito estressante.

Quanto tem a demanda, pela questão do próprio sistema, a gente acaba se fazendo diferente... você atende o paciente com dor... as vezes você tem oito minutos pra atender um e já tem outro. Você marca retorno. No dia do retorno, ele acaba sendo atendido por outro, que vai olhar o que você escreveu, ou nem isso.

(...) ai está uma coisa que o próprio sistema com que esta palavra 'médico' seja distante de seu ideal.

Cai naquilo que a gente já falou: como é que você vai fazer isso em um pronto atendimento com trinta pacientes em duas horas.

Como a gente vê os formados falarem: a gente tenta, mas peca.

A questão da humanização na relação tem inicialmente um caráter que enfoca a necessidade do aproximar do médico junto ao paciente. No entanto, permanece a postura de que o médico nada pode fazer a não ser ações de sua competência clínica, mesmo reconhecendo que há necessidade de se caminhar rumo a outras dimensões da intervenção em saúde, em uma postura tradicionalista e passiva com relação à situação que a realidade lhe apresenta ${ }^{35,36,79-88}$.

\subsubsection{Núcleo Temático 4: Sobre o Médico e o trabalho no serviço de saúde}

Com relação ao posicionamento do médico frente aos demais componentes da equipe de saúde, registrou-se a Medicina como profissão de status e alta posição hierárquica na equipe de saúde. 
As pessoas que estão lá em casa, é uma coisa de hierarquia, né... é um curso só pra quem pode. Ah.. tua mãe é técnica, tuas irmãs são enfermeiras e você é quem vai mandar, né? Então, tem essa questão ai, de hierarquia, mas eu acredito que todo profissional de saúde tem que trabalhar de equipe. Por que se tu pede pra um, o outro também ta no procedimento. Que é complicado essa parte, realmente é, mas se tu não fizeres teu paciente não vai sair bem. Mas nessa questão do que é ser médico, ser médico pra maioria das pessoas que tão ao meu redor é ter um status muito grande.

Esta perspectiva se mostrou ainda mais contundente com relação a equipe de

Enfermagem e a Enfermeira. A formação universitária foi apontada como espaço em que se construiu esta visão, inclusive sendo justificado o privilégio hierárquico, dada a grande carga de conteúdo que a Medicina possui quando comparada com a carga das outras profissões de saúde.

[refere-se a formação universitária] Colocaram um pouco isso pra gente durante a graduação. Acaba sendo muito aquilo... Não sei se vocês percebem... Que o médico tem... Acaba entrando em contato com uma carga maior de informações, mas não que ele queira... Mas acaba entrando em contato com mais informação teórica e, ao mesmo tempo, é meio que, exige-se dele que ele também seja capaz de fazer todos aqueles procedimentos básicos que seriam os que os técnicos de Enfermagem e a Enfermagem fazem.

O médico se utiliza do conhecimento para se posicionar hierarquicamente dentro de um hospital e também acaba fazendo com que esses outros profissionais acabem até se acomodando, por que eles acabam deixando a responsabilidade para o médico.

Acho que sem a Medicina, não a Odontologia, mas o trabalho da Enfermagem ia ser limitado. Por que o médico aprende todos os procedimentos, agora eu acho que os procedimentos de Enfermagem, todos os médicos são capazes de fazer.

Acho que todo profissional de saúde deve se reportar ao médico.

Foi até uma coisa que a gente discutiu... Lembra a lei do ato médico? Eu sou contra que qualquer outro profissional... que um enfermeiro ou um fisioterapeuta prescreva. Será que ele vai assumir a 
responsabilidade? Ai a gente vai ter que resolver as conseqüências de algo que a gente não teve o controle.

Tem área dentro do hospital, por exemplo, que o pessoal fala 'olha, avisa pro pessoal pra eles prepararem a sala de cirurgia'. Então, tem as circulantes, tem aquelas pessoas que ficam de um lado pro outro... Entendeu... O anestesista fala 'pega... Preciso disso... Preciso daquilo'. Então, em alguns pontos eles são eficientes fazendo o trabalho complementar ao do médico.

A posição do médico ali, na equipe, é mais como a de um herói... Que só tem responsabilidade.

Apesar desta centralidade do profissional médico na equipe, estes acadêmicos apresentam a percepção de que existe uma interdependência entre as diversas áreas de saúde, necessária ao atendimento integral dos pacientes. Denunciam que no ambiente hospitalar, apesar da proximidade física dos diversos profissionais de saúde e dos diversos especialistas da área médica, não existe um real trabalho em equipe multidisciplinar, mas sim várias especialidades e áreas atuando nos mesmos indivíduos, inclusive sendo deficiente a articulação destes diversos profissionais.

Pode dar a impressão que somente o médico é o profissional necessário. Por exemplo: como o médico vai tratar uma cárie dentária? São áreas específicas. Mas acho que não é realizado um verdadeiro trabalho em equipe. Um hospital não funciona sem enfermaria, sem enfermeira. Aí é que a gente vê que um hospital só anda se tiver todos os profissionais.

No hospital vi sérios problemas com o lance de trabalho em equipe. Existe odontólogo onde existe o serviço médico? Não. Entrega-se o formulário para encaminhar para o dentista. Pro fisioterapeuta... Não... Só há encaminhamento... Não há um seguimento.

Acaba sendo assim: tem reuniões que a gente passa no internato que é reunião da clinica médica com a clínica cirúrgica pra discutir determinado caso. Mas isso não é trabalho em equipe. Acho que você nem percebe. Acho falho... Incompleta esta abordagem. Trabalho em equipe é diferente disso. 
Tem uma quantidade de folhas pra suprem uma coisa assim [a equipe]. A gente fala o remédio, a equipe de Enfermagem cumpri. $O$ outro responde o parecer... Isso não é uma equipe... Nem trabalho em equipe.

Discute-se 'quantas sessões de fisioterapia deve ser feita em determinado paciente', 'e você, nutricionista? Qual o cardápio você prescreve? Acaba sendo uma posição crítica... Que acaba sendo o médico que correr atrás. Ele que tem que observar... 'Olha ele ta precisando de um fisioterapeuta...' então, o médico é que faz o encaminhamento, ou seja, o fisioterapeuta não tem a liberdade pra chegar, examinar o paciente.

A terapeuta ocupacional do Hospital Universitário tem em sua porta um receptáculo para que os médicos coloquem seus encaminhamentos... Ela me relatou que há mais de três meses nenhum residente, nenhum plantonista lhe encaminhou nada. Nenhum encaminhamento. Todos os pacientes foram buscados por ela, que saiu observando no hospital. As vezes ela diz para o médico 'o paciente precisa de uma atividade de terapia ocupacional...' e o médico rebate 'quem é você? Você é médica para decidir o que ele precisa ou não?' Isso não é apenas com os outros profissionais: acontece entre os médicos de diferentes especialidades também.

Uma vez eu vi um paciente na ortopedia que bateu a cabeça... A prioridade é sempre da neurocirurgia já que ele bateu a cabeça. É algo mais vital... Então o paciente estava com uma fratura, só que a gente estava esperando o profissional, o neurocirurgião, atender, fazer o procedimento e encaminhar para a ortopedia, onde eu estava. Se, de repente, a gente quebra esta hierarquia a gente é criticado. A gente na ortopedia acaba tendo que esperar. Quando o neurocirurgião der alta e encaminha para a ortopedia, aquele caso já não é mais dele. A gente já tinha que pegar e marcar a cirurgia de urgência que poderia ter sido eletiva, caso as duas áreas atuassem em conjunto, quando os dois podiam intervir no mesmo caso. A verdadeira equipe não existe.

É difícil falar de trabalho multidisciplinar. Cada um fica na sua área, na sua sala e empurram o paciente.

Segundo este grupo, prioritariamente se está atuando em Saúde Pública quando se atua em serviços públicos de saúde, mais especificamente na atenção primária. Apesar de se referirem em outros momentos da discussão, aqui silenciam 
sobre a complexidade da interação de determinantes de saúde na comunidade e que, a existência da complementaridade do setor privado no Brasil é um princípio do Sistema Único de Saúde, sendo que este setor responde pela atenção à saúde de uma parcela da população e, dessa forma, interfere nos padrões de saúde da comunidade como um todo. Neste sentido, desconhecem ou desconsideram, para suas colocações, que o SUS, através de convênios e outros instrumentos legais, articula-se com o setor privado para o atendimento de suas demandas por especialidades que não possui na rede de serviços públicos de saúde, de forma que a população que acessa apenas ao Sistema Único de Saúde em suas necessidades de saúde é, freqüentemente, encaminhada e atendida em hospitais e centros de especialidades privados.

Atuaremos em Saúde Pública no próprio atendimento em Unidade Básica de Saúde, na atenção primária.

Só de fazer faculdade em uma Universidade Federal a gente já atua. Todo mundo aqui já atua dentro da Universidade na Saúde Pública. Por que nada do que a gente faz ligado à universidade é particular.

Aqui na universidade Federal a gente atua em saúde pública. E, desde que eu entrei na universidade eu me apego neste conceito.

Acho que qualquer um pode fazer saúde pública, como eu te falei... Mas nós vamos ao que há de trará... Na atenção primária à saúde, quem for político fazendo estas obras que são necessárias. Qualquer coisa que tiver uma abrangência na saúde publica pode ser realizada também.

Contraditoriamente ao posicionamento apresentado anteriormente, a complexidade dos determinantes de saúde e da Saúde Coletiva são aludidas pelo grupo, que apresentam o conceito de que agir neste campo vai ao encontro do 
enfrentamento de articulações intersetoriais, com atores sociais muitas vezes de campos que não são prioritariamente da área de saúde e que o papel do médico neste contexto é mais amplo que o atendimento clínico, perpassando as questões do trabalho em equipe multidisciplinar. Referem que se trata do agir em coletividade, não individualmente.

A saúde coletiva vai extrapolar muito mais que a Medicina em si. Por que ai tu vai pegar saneamento básico, uma porção de outros assuntos que não dependem mais do médico. Ai você vai ter que unir não só a equipe médica, mas uma equipe de Agentes de saúde, a prefeitura, tudo aquilo que interfere na saúde de uma população. Que você não vise ali o paciente, o individuo... Não é uma coisa individual.

Não é só a questão da doença. É a moradia, higiênico-sanitária. Neste ponto, o médico é só mais um que vai integrar.

O médico acaba sendo apenas um conhecedor das conseqüências daquela problemática. Por isso que ele entra naquela ajuda constante também.

Saúde Coletiva vai muito além da Medicina.

A Saúde Coletiva compete à comunidade, em quem ela vai votar, aos nossos 'executores', à Prefeitura e todo mundo que trabalhar... Até... Claro que tem aquela coisa de sempre jogar para a população em si. Mas se a gente for analisar friamente é realmente dela o poder.

A gente vive em uma democracia, né? Antes tinha o lance 'dos cara pintadas' e tudo... e hoje em dia a própria população não vê... Esta parada... A pessoa fica parada até que "o calo aperta". Enquanto não passa aperto, pode até passar dificuldade, mas sorrindo... E tem que pensar na coisa a fundo.

Bem ou mal compete a eles, a população principalmente, mas todos estão envolvidos.

A gente teve oportunidade de ver... Tem os Agentes de Saúde... Tem pessoas voluntárias trabalhando com a gente... Tem as enfermeiras, tem o médico também... Que também ta lá... Sempre presente. Então, é uma equipe muito grande... E vai entrar certa política junto 
também... De que também é dependente... O prefeito, que vai ou não vai construir unidades de saúde adequadas.

É aludida a questão da dificuldade para o trabalho em equipe, como pertinente aos debates sobre o trabalho do médico no Sistema de Saúde. Inclusive sendo mencionado um papel central e com o maior status entre os profissionais da equipe de saúde, justificando que o médico apresenta maior conhecimento. E vão além: tomam como se fosse próprio da sua competência profissional competências que são do Enfermeiro, quando na realidade isso não acontece, dadas peculiaridades e atribuições legais de cada um das profissões aludidas. Revelam, portanto, a dificuldade de horizontalidade nas relações de trabalho e relações humanas do atendimento de saúde, assim como a dificuldade em tomar conhecimentos que não médicos como tendo o mesmo valor, questões que remetem ao contexto do processo ensinoaprendizagem em Medicina e a seu talhe tradicionalista e bancário ${ }^{35,36,79-88}$.

\subsubsection{0 produto das entrevistas individuais de acadêmicos de Medicina}

\subsubsection{Primeira Categoria: a universidade}

A estrutura da faculdade de Medicina foi apresentada como um fator que dificulta o processo ensino-aprendizado, não apenas no aspecto físico, que remonta o início do curso, mas também pela sua estrutura organizacional, a qual é referida como arcaica em relação aos demais cursos de Medicina do Brasil. 
A estrutura é muito arcaica. Nossa faculdade de Medicina é uma das mais antigas do Brasil e mantém essa estrutura durante todo esse período até hoje. As salas de aula eram as mesmas do tempo que ela foi fundada. O auditório agora está reformando, construíram um novo ambulatório.

(AMed 01)

Existe certa insegurança com relação a exercer profissionalmente a Medicina.

Esta insegurança tem origem na crença de que não estão preparados completamente para a profissão, inclusive afirmando que o tempo do curso de graduação em Medicina é pouco para a completa formação do médico, que somente se dará ao término da residência, o que já é conhecido no meio médico segundo estes entrevistados.

Tenho ansiedade de tentar entrar no mercado de trabalho. É aquela coisa: 'agora é com você, esta nas tuas mãos, a responsabilidade é tua'. Fico com ansiedade de corresponder a espectativa do paciente.

(AMed 01)

Acho que 6 anos não são suficientes para formar um profissional completo, mas também tem tempo para você aprender você se interessar.

(AMed 03)

Você sai faculdade é já é um médico. Tem muita coisa que me sinto muito apto a dar diagnostico, a saber o que é isso, o que é aquilo. Agora, conduzir cada doença... eu acho que já tem uma deficiência porque é muita coisa delicada, enquanto que para dar o diagnostico preciso saber que exame pedir.

(AMed 01)

Todo médico tem que restringir sua atuação a uma especialidade. Ele não pode ser um medico geral. É muito complicado ser competente como generalista. $O$ médico tem que restringir para poder fazer uma coisa bem feita.

(AMed 01)

Diria que teoricamente estou em parte preparado, mas tecnicamente não. $O$ que os professores passam para gente e o que a gente percebe com os outros colegas que são mais antigos é que o médico acaba se formando na residência.

(A Med 05) 
Quero logo entrar na residência quando eu terminar. Eu entrando na residência eu vou restringir minha área de atuação. Então fica bem mais simples. Agora se pensar na Medicina como um todo é complicado. Ser generalista é muito mais difícil.

(AMed 01)

A principal deficiência apresentada na formação médica, em nível de graduação, está na ausência de problematização pelo distanciamento e falta de articulação entre teoria e prática, de forma que o curso não prepara para a atuação na realidade e, sim, sedimenta conhecimentos teóricos. É apresentado que, como resistência a este contexto, os próprios acadêmicos procuram no transcorrer do curso estágios clínicos extracurriculares. As disciplinas básicas são trabalhadas sem interface com a prática clínica. O professor não é apontado como o mediador deste processo, de articulação entre teoria e a prática médica, de forma que fica a cargo dos discentes estabelecerem a correlação com a prática médica.

Se eu fosse esperar só da universidade provavelmente eu não me sentiria preparado, mas eu desde o início eu sempre fui atrás, desde o 3 o período que eu estagio em plantão médico. Eu acho que falta muita coisa principalmente da parte da prática.

(AMed 02)

É uma grande carência: já começa do ensino pela parte teórica e na parte prática falta muita coisa.

(AMed 02)

Muitas vezes nós vínhamos para aula. Nós não queríamos aquela aula bonitinha, em data show. A gente queria experiências, queria prática.

(AMed03)

Eu acho que a principal falha é a falta de associação da teoria com a parte prática. Se o aluno não buscar por si mesmo atrás e desse tipo de coisa o que a faculdade dá talvez não seja suficiente. E na parte profissionalizante da Medicina tem um problema: a parte teórica 
como clinica médica, clinica cirúrgica, é só teórica. Ai quando você vai para a parte prática que são os estágios, a gente fica só no hospital e não tem sala de aula e nem nada teórico. Só o hospital mesmo.

(AMed04)

Nos primeiros anos a gente viu aquela parte básica, bases biológicas, que não dá a base para saúde, para o trabalho na saúde, não tem muita relação direta. É mais indireta. E na parte profissionalizante foram três anos de várias disciplinas e na verdade não aborda diretamente como ser médico. Te dão a informação, aquela que você precisa saber, mas não basta saber teoricamente. É apenas vivenciando uma situação que se aprende de verdade.

(AMed04)

Acho que existe deficiência principalmente na pratica. Acho que principalmente na pratica é onde a gente sente mais falta, que as turmas às vezes já sentem carência de professores que articulem a teoria.

(AMed05)

Portanto, a estrutura do curso de medicina, com talhe tradicionalista, desarticulação entre teoria e prática, é apontada como um fator prejudicial ao ensino, o que vai ao encontro das idéias freireanas ${ }^{35,36,79-88}$.

\subsubsection{Segunda Categoria: 0 professor no ensino de Medicina}

Segundo os entrevistados, existem três tipos principais de docentes no curso de Medicina, caracterizados pelos seus compromissos com o curso e nas relações interpessoais com os discentes. O primeiro tipo de professor é caracterizado pelo grau de cobrança extrema em relação ao desempenho dos alunos, inclusive de forma incoerente com o nível de dedicação ao ensino que o próprio professor tem, rispidez na relação com o aluno criando barreira para interpessoalidade. O segundo tipo tratase do professor que não demonstra preocupação nem com o ensino, nem com a 
instituição, caracterizado por ministrar aulas independente de o aluno estar ou não aprendendo. O terceiro tipo de professor busca aproximação do aluno, demonstrando amizade e interesse no aprendizado do mesmo, além de preocupação com o ensino e com a instituição.

Quando tu acha que o professor tem muita pose, que gosta de dar sermão, que gosta de brigar com o aluno, cobrar coisa sem muito oferecer em troca ou as vezes oferece mas exagera um pouco, esse é o professor que é distante. Que você tem medo de chegar perto. 0 omisso é aquele que vai na faculdade quando quer, dá uma aula do jeito que ele quiser, quando ele quer. Sem compromisso nenhum com o aluno. E o orientador é aquele que se preocupa, que está preocupado com a grade, que está preocupado com o ensino. É aquele aula que foi dada para poder cobrar. Acho que tem os três tipos de professores no curso. Dos três tipos acho que o do meio é o que prevalece, em termo de quantidade.

(AMed 01)

Conforme com o marco teórico freireano ${ }^{35,36}$, puderam ser identificadas a presença de diversas características da Educação Bancária no processo ensinoaprendizagem destes acadêmicos do curso de Medicina: (1) verticalidade na relação professor-aluno: presença de distanciamento entre o docente e o discente ocasionado pela postura docente de detentor do conhecimento médico e que o mesmo deverá ser depositado aos discentes que se propõe à recebê-lo de maneira passiva e não utilizando de criatividade no processo; (2) educação punitiva: o discente, independente de ter tido aula ou auxílio do docente no processo, deve saber os conteúdos que são cobrados, inclusive, além do que foi ministrado oficialmente, sendo que, muitas vezes, estes discentes tiveram que estudar sem o auxilio dos docentes para dirimir suas dúvidas; (3) priorização da cultura do silêncio e silenciamento do 
corpo discente no processo ensino-aprendizagem: o medo está presente nas relações entre docente e discentes, na medida em que estes se furtam a dirimir dúvidas, temendo ser repreendidos pelo primeiro; (4) falta de compromisso com o aprendizado do aluno: além do descaso de alguns docentes, que faltavam em diversas aulas e não prestavam justificativa aos discentes, em alguns casos caracterizaram que existiram docentes que não se preocupa em ministrar aulas com a participação dos discentes pautando a atividade didática exclusivamente em aulas que segundo o marco teórico freireano podem ser caracterizadas como eminentemente depositárias, inclusive havendo exemplos de docentes que se atinham totalmente a leitura de slides projetados durante as aulas, não acrescentando conteúdos, o que é relatado pelos discentes entrevistados ao se referirem que não haveria diferença de aprendizado entre ter lido por si mesmos a bibliografia pertinente ao conteúdo ou ter presenciado determinadas aulas.

\begin{abstract}
Alguns professores impõem como uma barreira entre eles e os alunos. Não conseguem levar conhecimento como tem aqueles que tratam de igual para igual. Quando o professor é distante dá aquele medo de as vezes perguntar besteira, mesmo para as perguntas mais simples.
\end{abstract}

(AMed04)

As vezes é uma pergunta simples, que para gente é a chave de aprender tudo e a gente fica meio ansioso se precisar perguntar. Dá medo por que o professor vai falar que já faz tempo que você viu aquilo, que você deveria saber. Já cria aquela barreira. E assim que a gente não pergunta mais. Que a gente parte para estudar sozinho. Tem vários professores assim, que as vezes dificultam no aprendizado.

(AMed04)

Existem aqueles professores que vão lá fazer por obrigação ou para querer se impor como ser um ser superior e que o aluno é obrigado a 
fazer muita coisa por que é inferior. Coloca aquela barreira do aprendizado. Esse acaba sendo pior.

(AMed04)

Apesar de certos casos o ensino não ser bom, tudo era cobrado nas provas. $\mathrm{O}$ aluno tem que estudar de uma maneira ou outra. Eu fui me adaptando a esse ritmo. Na maioria das aulas eu não queria ir, porque eu não sabia se ia ter ou não.

(AMed 01)

Na faculdade pegávamos os programas. Os professores fazem uma relação dos assuntos que vão ser ministrado. Dá para gente ler 'numa boa', só que quando a gente chegava na aula os professores chegavam e diziam 'se vocês querem aprender, vão para biblioteca pois a aula já acabou'. Eram dois minutos de palavras e todo mundo estava liberado para ir 'aprender'.

(AMed03)

Eu não queria falar esse termo. Não queria falar isso, mas é o finge que ensina e finge que aprende. Eu finjo que to ensinando e você finge que aprende. Porque não tinha muita coisa de útil, era muita coisa teórica, sem sentido prático. Você vê que fica dois anos lá só enrolando. A vontade que eu tinha era de sair da sala. Não vir mais. Pensava que, como eu tinha o texto da aula, era melhor ler em casa. Não precisava de professor para ler conteúdo. O que eu gostaria era de um professor na faculdade que detalha aquela coisa que não se aprende dentro de um livro. É como se fossem dicas, mas é como aquelas dicas diárias que vai aumentando sua sabedoria. Você precisa de um professor mais experiente para te orientar e dizer o que tem que estudar porque esse será o seu dia-a-dia como médico. Sinto que meus professores não têm esse compromisso de ser por exemplo como um pai, alguém que te orienta. Eles dão uma aula e eu leio no livro.

(AMed 01)

O aluno aprende praticamente por conta própria. Não acho que os professores te preparam nem para fazer prova. Tu tem que te preparar praticamente sozinho. As aulas na maioria não são tão bem conduzidas. Existem disciplinas que são muito bem conduzidas mas na maioria dela eu acho que tem um pouco de desinteresse por parte dos professores. Eles só vão levando, não tem aquele empenho, aquele interesse. Acho que a faculdade em si não te prepara. $O$ aluno tem que correr atrás.

(AMed 01)

Com relação à aula, tem professor que leva meio que com descaso, não está muito preocupado. É engraçado que dá a impressão que tem professor que parece que não passou pelo que a gente passou. Porque é justamente por ter visto toda a dificuldade que eles 
deveriam correr mais atrás e puxar o aluno, despertar o interesse mesmo. $O$ bom professor puxa o aluno, faz o aluno gostar daquilo. Tem matéria que é chata e todo mundo acha chata e o professor faz questão que continue chata.

(AMed 02)

Parece que perdeu o compromisso totalmente com o ensino, apesar dele continuar sendo professor. Saber é uma coisa, ensinar para outra pessoa é outra e tem muito professor que não tem essa mentalidade. São bons, conhecem muito, mas eles não sabem passar e também não se preocupam se estão ou não passando a informação de maneira certa. Então eles vão lá dão a aula deles.

(AMed 02)

Tinha algumas aulas eram aulas chatíssimas e que o professor também não tinha didática nenhuma. Acabava sendo perda de tempo. Para mim era uma perda de tempo. Eu preferia ir pra casa e ler porque dava no mesmo. Ficar em casa e ler seria mais proveitoso. Mas não fazia. Acabava indo assistir o tempo daquela aula. Você vai fingir que aprende e o professor finge que ensina.

(AMed 02)

O que a gente apresente depende muito daquele material humano que está ali para ir passando o ensino. Se um professor não dá aula ou dá aula de uma maneira que não estimula, não ajuda a aprender.

(AMed04)

Em uma disciplina todos dividem entre eles a turma para aulas praticas. Cada um fica com uma turma pratica. Tive professores que nem iam na clínica. Chegava lá e não tinha professores. Nem apareciam na aula. Tem professores que 'levam com a barriga mesmo'.

(AMed04)

A maioria, tem muitos casos partindo principalmente partindo dos mais antigos, que estão lá desde o início e que não querem largar o osso. O professor mais antigo é o mais difícil do aluno chegar perto. Ele está lá para se aposentar e garantir a aposentadoria federal. Não fazem nada por que não tem estímulo, já que estão para ir embora. $\mathrm{E}$ não permitem que outros mais novos façam no lugar deles.

(AMed 01)

A permanência dos docentes com postura bancária no curso de Medicina foi justificado pelos entrevistados, pelo status legado da sociedade ao professor 
universitário, de forma que o docente seja referência no mercado de trabalho médico, a despeito do regime de trabalho em dedicação exclusiva e tempo integral ao serviço público federal.

Eu acho que ser professor da federal dá status no mercado de trabalho. Principalmente em termo de divulgação. Se é professor de universidade tem outro status em relação a quem não é.

(AMed 01)

Outra característica da educação bancária, existente no curso de Medicina, refere-se a tentativa de mudanças neste paradigma bancário por professores com menos tempo no ensino superior federal. A tentativa de mudar as estruturas cristalizadas deste modelo de ensino, ocasionaram reação contrária dos professores antigos e conseqüente desgaste nos inovadores.

\begin{abstract}
A estrutura interfere demais na qualidade de ensino. Os outros professores mais novos de universidade, que querem mudar alguma coisa, estão de mãos atadas, não podem fazer nada porque lá de cima vem 'balde de água fria'. Eu acho então é uma estrutura que está lá como se fosse o sistema político brasileiro. Quem quer mudar não vai conseguir porque tem que se adaptar ao sistema. Agora, não vou dar soluções aqui que talvez não sejam certas. Acho que o problema é cultural.
\end{abstract}

(AMed 01)

Paralelamente, a existência de professores pautados sua ação pedagógica em postura bancária, os entrevistados relatam a existência de uma relação horizontal entre professor e aluno, cujo modelo pedagógico é ideal para o ensino em Medicina segundo os depoimentos. São características do ensino horizontalizado, encontradas 
na prática de alguns docentes do curso de Medicina: (1) proximidade entre o aluno e o professor: os discentes aludem ao docente como amigo, como alguém prioriza intersubjetividade no processo ensino-aprendizagem; (2) entendimento do aluno como ser humano: o discente é respeitado como semelhante, é tratado de maneira humanizada pelo docente; (3) interesse em dirimir dúvidas e deficiências do aluno no processo ensino-aprendizagem: o docente mantém-se aberto ao diálogo, demonstrando para os discentes seu empenho no ensino e que está aberto sobre os problemas e dúvidas que os mesmos tenham durante o processo, mantendo uma postura muito mais de orientador, do que condutor, no processo.

Acho que professor tem que ser como se fosse aquele orientador. Não apenas um professor, um orientado, mas sim o cara que está te orientando, que te conduz. Alem de te ensinar, te ensina mas com aquela orientação, aquela experiência, sabedoria. Muitos professores contribuíram muito comigo assim. Valeu a pena ter conhecido e ter tido a oportunidade de estudar com eles. Mas a maioria não.

(AMed 01)

Varia muito quanto ao tipo de professor. Tem aquele professor que acabou se tornando um amigo, que além de tirar todas as dúvidas, toda dificuldade do aluno, tentou solucionar, tentou dar o melhor de si para o aprendizado do aluno.

(AMed04)

Várias características apontam para a diferença entre os professores. Primeiro o interesse do professor, a capacidade do professor acho que também conta. Acessibilidade também porque se é mais acessível você sente mais vontade de chegar, de tirar uma dúvida. Também tem aquele professor que você se que é mais humanizado, mais humano e também tratando o aluno com respeito.

(AMed05)

Nós tivemos alguns professores politizados que se preocupam com esse lado social, tentam orientar o aluno até como ele deve se portar com o paciente, coisa que se deve falar ou não. Vejo que esses professores são os mais criticados por terem essa visão politizada. Então se um quiser mudar é muito difícil. Acho que por isso eles são 
mau falados e acabam com o tempo desmotivando, se restringindo a uma sala de aula que já é uma coisa muito grande. Tem um poder de politizar dentro de uma sala de aula.

(AMed 01)

Os professores da saúde coletiva já têm essa mentalidade mais esquerdistas. Vamos dizer que são mais socialistas. É um ponto de encontro aos cirurgiões, aos cirurgiões cardiovasculares, aos neurocirurgiões que já são mais capitalistas. Acho que tem essa diferença. É minoria do pessoal que lida mais com o povo e pelo menos demonstra ser mais preocupado com a população, com a coletividade. É a minoria dos professores. Por isso eu acho que é muito pouco o que passaram para gente nesse sentido.

(AMed05)

Todas estas considerações, reforçam a idéia da necessidade de reformulação do modelo pedagógico em Medicina, orientando-o para uma abordagem mais histórico-política e crítico-social ${ }^{35,36,79-88}$.

\subsubsection{Terceira Categoria: A humanização no modelo pedagógico}

Formação do médico, no modelo pedagógico do curso de Medicina a que o presente trabalho se refere, é orientada mais à formação técnica do profissional e muito pouca a um talhe humanístico, conforme as ferramentas educacionais destinadas ao ensino humanizador e crítico-social na estrutura do curso, que na percepção dos entrevistados, reduzem-se a alguns diálogos, não são sistematizados e não previstos na estrutura curricular, com os docentes dos cursos, além de algumas disciplinas. Destas disciplinas, ressalta-se Iniciação ao exame clínico, que trabalha a relação médico-paciente e os contatos que os acadêmicos tiveram através do Estágio 
em Medicina Social e Preventiva, na etapa de internato do curso, em que tiveram acesso a realidade vivenciada pela população ribeirinha.

De longe a questão técnica, a questão teórica é o foco do curso. A questão humana foi trabalhada, mas é o trabalho no dia-a-dia de ambulatório e de enfermaria. Orientado por orientador independente. Ninguém segue uma conduta. Você aprende e segue a conduta do orientador. Não existe formação específica. Só que o desse ou daquele orientador conseguiu captando alguma coisa humana, algum ensinamento dele, de como conduzir o paciente.

(AMed 01)

Não me recordo de uma disciplina em si. Ás vezes parte do professor. O professor que leva uma conversa sobre as questões de humanização, uma conversa na relação médico-paciente. Mas disciplina, nenhuma.

(AMed05)

Tivemos uma disciplina chamada iniciação ao exame clínico que a gente cursa logo nos primeiros períodos. Acho que é a única que ainda tocou no assunto da relação médico paciente. As demais podem até falar mas é mais superficial ainda.

(AMed 02)

É surpreendente a vida dos ribeirinhos. Por que a realidade deles é tão precária que a maneira como eles lidam com as dificuldades acaba ensinando um pouco a gente. A maneira como eles... a gente começa a perceber que não é um povo ignorante porque quer. É um povo ignorante porque não tem acesso a educação. Eles ensinam muita coisa principalmente a parte muito mais humana, a maneira como eles se juntam para superar suas dificuldades. A gente aprendeu muito mais a parte humana, eles deram uma aula para gente do que que é viver em sociedade apesar de todas as dificuldades que eles têm.

(AMed 02)

A necessidade de ações humanizadoras, para que o profissional não apenas seja treinado, conforme o universo freireano apresenta ${ }^{35,36,79-88}$, mas sim que seja 
formado como ser humano que é destaca-se sobremaneira destes diálogos com os acadêmicos do curso de Medicina.

\subsubsection{Quarta Categoria: A humanização na prática de Medicina.}

$\mathrm{O}$ atendimento humanizado é entendido pelos acadêmicos de Medicina como o atendimento clínico em que existe certo diálogo informal entre o médico e o paciente, não abordando o paciente apenas como um portador de patologia a que o médico se destinará a curar, mas como um ser humano, semelhante, que demanda respeito e paciência. A semelhança entre o médico e o paciente foi conceituada através das suscetibilidades humanas, que ambos estão sujeitos por serem seres humanos, tanto no aspecto biológico, como no aspecto psicológico e social.

Atender de maneira humanizada é procurar não apenas ver a doença. É também 'bater um papo', saber como é que está a família.

(AMed 01)

O médico deve tratar o paciente com respeito. Não achar que o paciente não tem nada se ele está com um caso simples. Se o paciente está dizendo que tem algo, tem que ter paciência para tratar o paciente com respeito.

(AMed 01)

O médico lida com uma das coisa mais preciosa da gente, que é a vida. Tem que levar isso com responsabilidade. Não pode ser frio, não pode ser direto, não pode ser grosso, tem que saber levar essas coisas, por que está lidando com ser humano. Tem que ter uma humanidade. Confortar da maneira mais amigável possível.

(AMed 02)

O medico não é nenhum deus e o paciente não é qualquer um. 0 médico tem angustia, tem dúvidas, tem sentimentos. $O$ paciente a mesma coisa. Então a diferença é ali, no momento em que um tem o conhecimento para dar para o outro que está querendo comprar 
esse conhecimento. Um tem uma expectativa no outro e o outro tem a possibilidade de vender a saúde. É uma profissão com seu glamou. É a única coisa especial, mas como pessoa não tem diferença do paciente.

(AMed 01)

Paciente é aquele que vem com mais dificuldade, que vem precisando de mais confiança, de uma atenção maior. Tem pessoas que precisam de mais atenção, tem pessoas que precisam que a gente converse com mais calma, tem pessoas que você pode falar mais direto.

(AMed 02)

Não existe diferente entre o profissional e o paciente porque as diferenças são apenas que a pessoa estudou aquela área especifica mas como pessoa não. Cada um é igual ao outro. Não existe essa de ser superior não.

(AMed04)

Humanização é entendida como decorrente do vínculo, entre o paciente e o médico. Para este vínculo ser desenvolvido, os acadêmicos de Medicina apontam necessidade de tempo de contato e de aproximação entre ambos. A questão do tempo refere-se tanto ao tempo de consulta, quanto ao período de tempo em que o profissional acompanha determinado paciente. O conceito de aproximação se encontra imbricado na temática da verticalidade/horizontalidade entre médico e paciente, sendo necessária a postura horizontalizada do profissional para que haja efetivamente aproximação, segundo as considerações destes entrevistados.

Acho que isso é humanização. Isso é humanização da relação medico - paciente: é essa questão de você ter essa capacidade de através desse bate-papo, através dessa interação fazer o paciente lhe ver como um ser humano como ele e se sentir visto por você também dessa forma. Eu acho que é ai que ta mais ou menos a chave da questão de que não tem uma hierarquia que o medico se sobrepuje e também nada que faça que o paciente se sinta inferiorizado ao 
médico, como se o medico fosse um ditador ou fosse alguém que estivesse acima dele.

(AMed05)

Para ter a intimidade maior, entre o paciente e o médico, capaz de profundidade maior tem que ser decorrente de um período de acompanhamento. Acompanhamento sempre é necessário para criar vínculo, para criar aquela confiança maior entre o paciente e o médico.

(AMed04)

O mais importante da relação médico-paciente é a confiança. Perdeu a confiança do paciente, perdeu o paciente. É melhor encaminhar para outro médico. Como é que você vai ganhar confiança? Confortando da maneira certa, é conversando, é mostrando para ele, tratando da melhor maneira que pode ser possível, como se fosse um parente seu, um filho seu, um irmão seu.

(AMed 02)

Quero tentar fazer isso, poder sentar, olhar para as pessoas, conversar com elas nem que seja uma coisa que não tem nada a ver com a doença dela, mas que vai deixar ela mais tranqüila, vai tranqüilizar. A importância é confortar, é adquirir aquela confiança do paciente porque não adianta você tratar, você só escrever. Os pacientes nem tomam o remédio. Eu já vi muito disso. Um parente meu falou assim 'Não, aquele médico olhou para mim, viu o raio $x$, passou uma endoscopia, nem vou tomar esse remédio. Ele nem olhou na minha cara'.

(AMed04)

O vínculo da boa relação médico-paciente se consolida justamente nesse aspecto, na conversa, do escutar, do interagir. Eu acho que isso é o que consolida uma boa relação medico-paciente. Muito mais do que ser apenas aquela relação clínica, técnica, que o médico não pergunta o que o paciente acha da política, como é que está a família, se alguém está doente, se não está passando por algum problema, por alguma dificuldade financeira. É que o que consolida. É o médico saber ouvir. Acho muito importante o medico saber ouvir. Mais ouvir do que apontar.

(AMed05)

Para os entrevistados, o momento de contato entre paciente e médico não acontece apenas à relação clínica entre doente e prestador de serviço, mas também uma relação interpessoal em que o entorno social do paciente e o médico tem 
interface intersubjetiva. Neste contexto, além da ação clínica ocorrem trocas entre o médico e a realidade do paciente, que é divergente com a do médico e ocorrem ganhos e crescimentos enquanto ser humano para este.

É sempre uma troca. É o mais interessante de você trabalhar na rede pública. As vezes é exatamente essa troca, troca de informação porque a realidade que os pacientes têm é outra, então você tem que conversar sempre. Tem algumas coisas que você só consegue enxergar quando o paciente te fala. A gente trabalhou muito com população rural e lá a gente aprendeu, não tenho nem dúvidas, que a gente aprendeu muito mais do que ensinou.

(AMed 02)

O paciente pode chegar no teu consultório de bom humor, de mau humor, irritado, cansado, com vários problemas, pode levar isso para dentro do consultório mas o médico não. Quando o paciente vai no médico ele não leva apenas a doença, ele leva tudo isso. E por isso que o médico não pode ver apenas a doença. Tem que também ver o paciente como um todo, tudo isso que está agregado ao fato de o paciente estar doente.

(AMed05)

Com relação a percepção do médico e de suas potencialidades de ação em sociedade, a imagem do médico foi delimitada pelos entrevistados como um profissional destacado tanto em status como em recursos financeiros. Esta imagem refere-se ao conceito sobre a profissão que a própria sociedade lega a Medicina. A posição privilegiada do médico não se refere apenas a sociedade em geral, mas também dentro da equipe de saúde, em que este profissional apresenta certa centralidade em relação aos demais profissionais. Na medida em que o Brasil é um pais capitalista, estas questões são importantes na delimitação da influência do profissional médico em sociedade, acrescido ao fato de que o médico desempenha um trabalho extremamente valorizado, na medida em que lida com as vidas humanas e 
com grande número de pessoas durante seu exercício profissional. Resultante deste contexto, o médico não apenas influencia no serviço de saúde e na saúde de seus pacientes mas sua atuação tem implicações políticas e eleitorais segundo os entrevistados.

Se você falar que faz Medicina, as pessoas já te olham diferente.

(AMed 02)

A Medicina é uma profissão especial por causa da expectativa que a pessoa cria nela. É como se a pessoa colocasse sua vida nas mãos de uma outra pessoa. A pessoa por exemplo é uma mulher, que vai no ginecologista, chega e conta a sua intimidade. Tu não vai chegar com qualquer um e fazer isso. Então é uma profissão especial.

(AMed 01)

A Medicina é ligada a dinheiro. Você acha que o cara é médico tem dinheiro. Se for analisar, ele é médico e tem dinheiro mas é porque ele trabalha muito. Se for observar um cirurgião geral, existem alguns que dão 36 horas de de plantão. Se estressa, sai cansado e tem um carro, um Honda Civic, mas porque deu 36 horas de plantão acordado trabalhando. Então é o custo benefício. Eu acho que o médico ganha bem, mas ele trabalha também. Tem áreas que você trabalha um pouco menos e ganha um pouco mais.

(AMed 02)

Não é só a questão do médico mas em vários outros campos é que aparece essa diferença de nível social, de nível sócio econômico. No Brasil isso é como se fosse uma hierarquia mesmo. Que quem tem mais é quem manda, é quem contrata, é quem emprega. Quem não tem é quem é empregado. Não é só da parte do médico mas às vezes do próprio paciente que já se posiciona inferiorizado em relação ao médico, por ele não ter arcabouço intelectual, cultural, ele acaba não podendo dialogar com o médico. O paciente acaba não podendo, não tem essa capacidade de diálogo. Aí o que acontece é que a palavra do médico acaba sendo uma ordem. Quando o médico atende uma pessoa que é um outro médico, que é um advogado, que é um juiz, alguém que é um pouquinho mais instruído, esse paciente argumenta o porquê de estar fazendo determinada conduta.

(AMed05)

Em termos sociais, querendo ou não, a própria sociedade coloca que o médico tem status. Quando você é médico a própria sociedade te trata diferente, te dá um valor maior. Mas nós não somos pessoas 
iguais? Porque esse valor então? É uma profissão, é bonita, uma profissão que você salva vidas e tal, mas como pessoa eu sou igual. Eu sou igual a todos. Só que a própria sociedade impõe, coloca o médico em um patamar superior. Alguns médicos gostam dessas coisas, mas é a sociedade mesmo coloca isso desse jeito.

(AMed04)

Existe uma hierarquia social sim. É uma coisa que não dá para contestar porque dentro da área de saúde cada um tem como se fosse um papel. Dentro do hospital é como se fosse um quartel. Tem o soldado, tem o general, o sargento e o cabo. Na Medicina não é diferente porque tem o médico, tem a enfermeira,as auxiliares, os técnicos e depois o paciente. A sociedade que utiliza é a mesma que impõe essa hierarquia.

(AMed03)

Eu acho que tem médicos que gostam desta superioridade que a sociedade thes coloca. Mas o médico sofre em manter aquela superioridade em geral. Somos todos iguais. Não é natural ser assim, se achar superior a alguém. Mas têm muitos profissionais que acham que por que sabem uma doença são melhores que todos. São acima de Deus. É maior que todos, é mais importante, que só ele vai salvar, mata, faz tudo. Então é um Deus. Ele é um Deus, ele é o que pode, quem pode só para ser o centro.

(AMed04)

Na época eleição é marcante. O médico influencia a população de uma maneira ou de outra, justamente por esse admirar que as pessoas tem pelo médico. Nessas campanhas sempre chamam os médicos para fazer atendimento e vestir a camisa do político porque sabe que aquilo é voto garantido. Porque a população confia naquele médico. 0 médico é formador de opinião, tem que ter muito cuidado.

(AMed 02)

A minha profissão assim tem um poder de penetração muito forte. A pessoa abre seu íntimo, entregar sua intimidade nas mãos de outra pessoa. É um poder político também, mas em termo de penetração em massa, tem esse poder de penetração muito grande. Pela demanda de atendimentos

(AMed 01)

Apesar da clara conceituação de humanização e tratamento humano, o grupo silenciou-se sobre a implicação do médico nas articulações em prol da saúde do 
paciente, que não pautadas na ação clínica. Isso se torna ainda mais importante, na medida em que reconhecem o médico como ator social de influência e esta poderia ser utilizada em prol dos comunitários, ainda mais em um modelo como o PSF. Este silêncio com relação a estas considerações revela a falta de comprometimento com o semelhante, características desumanizada no universo conceitual freireano ${ }^{35,36,79-88}$.

\subsubsection{Quinta Categoria: Desafios à humanização}

A existência de grandes demandas de atendimentos clínicos nos serviços de saúde foi considerada um fator na contramão de atenção médica humanizada, uma vez que é necessário tempo para a mesma e as grandes demandas não permitem que o profissional possa se dedicar desta forma aos seus pacientes, priorizando a doença e a ação clínica reducionista.

Você vai as oito horas para o ambulatório. Ai começa a atender e vai até mais ou menos onze horas, onze e meia sendo que nunca atende apenas os pacientes que estão marcados. Sempre tem os extras. As vezes extrapola que vai até meio dia, uma hora. E mesmo assim ainda tem que mandar pacientes voltar para casa porque se for atender todo mundo não tem jeito. Então é uma coisa de estresse. Me estresso porque o paciente que você manda para casa também precisa ser atendido. Acho que não dá pra ter uma atenção humanizada em cem por cento. É muito fácil se falar do que é ideal mas é difícil dizer que na pratica você vai fazer isso. É fácil falar que vou fazer mas eu quero ver você olhar lá ver se o médico realmente está fazendo. É diferente falar de entender o que está acontecendo. Então eu acho que não dá para ser tão humano no atendimento no sistema publico de saúde.

(AMed 01)

É uma coisa que eu quero praticar na minha profissão esse estar lado a lado, dar atenção para as pessoas, conversar. É complicado 
também porque o sistema também deixa meio difícil. Você tem que atender trinta em posto de saúde.

(AMed04)

Quando a demanda está menor você vê que tem tempo para conversar com o paciente, poder dar uma atenção maior, poder conversar.

(AMed 01)

A dialogicidade do profissional para com o paciente na atenção mostrou-se outra barreira a efetiva humanização. O médico foi apresentado como um profissional que detém monopólio do conhecimento de saúde e que para restabelecimento da saúde, o paciente deve se submeter a autoridade médica no tratamento, independente do entorno sócio-cultural do paciente e das questões de ética. Menciona a existência de conflitos ocasionados pelo diálogo do médico, ineficiente ao entendimento do paciente, não mencionando horizontalidade e negociação na relação entre as partes envolvidas no processo, como se o problema fosse apenas cognitivo do paciente para com o conhecimento médico. Esta postura autoritária é ainda mais contundente no serviço público de saúde, dado que estes médicos entendem que o paciente não está pagando pelo atendimento. Esta perspectiva sobre dialogicidade e monopólio do conhecimento de saúde muda de sentindo quando na relação médicopaciente este último trata-se de um profissional considerado esclarecido, como seria um paciente de nível superior, segundo estes entrevistados.

O paciente que não tem uma boa adesão ao tratamento é um paciente problemático. Vai fazer mau para ele e para o médico. 0 paciente que a gente pede para tomar o remédio e dá determinada hora e ele esquece, ou não toma ou é relapso de qualquer maneira, atrapalha o tratamento. Quando o paciente assume o compromisso 
de receber o tratamento médico, ele também tem que assumir o compromisso de seguir certo o que o médico fala. Se o médico falou que é para fazer isso, é isso que é para fazer. Porque o médico sou eu. Não é o paciente ou nem é o balconista da farmácia. Acho que o paciente tem que ter essa noção, ele tem que querer ficar bom, tem que aderir ao tratamento de forma exata. Pelo próprio respeitar a palavra do médico. $\mathrm{O}$ que o médico fala ele tem que aceitar.

(AMed 02)

No atendimento particular a pessoa se acha no direito de ter um bom suporte e resposta satisfatória aos seus problemas de saúde. 0 paciente do serviço publico na maioria das vezes, se submete a tudo que o médico fala.

(AMed03)

O médico tem o poder nas mãos de mudar a vida de uma pessoa. Não é para qualquer um estar exercendo esse tipo de profissão. E o paciente sabe disso.

(AMed 01)

$O$ atendimento tem diferença entre quando você fala que é medico, que é do meio de saúde, e quando você falar que não é. Eles dão atenção maior, tratam de outra forma quando é do meio. Sabem que você vai entender o que estão falando então vão ter mais cuidado.

(AMed 01)

Quando o paciente não é do meio os médicos tentavam não ser muito detalhistas. Na época que eu ainda não era estudante de Medicina, os médicos falavam de uma forma que talvez eu não fosse entender mesmo. Então não procuravam explicar. Depois que me tornei estudante de Medicina senti que há mais detalhamento.

(AMed 02)

Se eu fosse atender uma pessoa leiga, por exemplo, teria uma forma de falar. Se eu fosse atender um medico eu teria outra forma de falar, mesmo porque eu posso ser mais direto com médico que ele vai entender o que eu estou falando.

(AMed 01)

Um achado particularmente interessante na imersão do universo empírico dos acadêmicos do último período do curso de Medicina é a relação entre humanização e o atendimento particular. Para os entrevistados quando o paciente procura o atendimento particular altamente especializado, muitas vezes, o médico não demonstra simpatia ou 
acolhimento com o paciente, e não mencionam necessidade de humanização nestes casos.

Se no atendimento particular existe uma postura mais próxima e humana do médico para com o paciente, estes acadêmicos apontam como boa estratégia de marketing para que o paciente retorne com o mesmo médico nas suas necessidades de saúde.

Tem aqueles casos também, por exemplo uma professora que é ginecologista e o consultório particular dela vive lotado. Ela é do tipo da mulher que não trata bem o paciente, conta a verdade 'nua e crua', abre o jogo 'você tem isso entendeu? Vai precisar desse remédio caríssimo'. Ela fala assim por que quando o paciente vai no consultório dela ele pode pagar para tomar remédios caríssimos.

(AMed03)

Sempre fui atendido no convênio. Alguns médico até tinham mais boa vontade. Mas sinceramente a grande maioria não tinham. A consulta era 'oi. Tudo bom? O que você tem?'. Olhavam para mim, me examinavam, prescreviam e tchau. Alguns poucos tinham aquela diferença, aquela nota, quando o médico te dá mais atenção, olha para o paciente, olha para você. Era melhor para o marketing pessoal.

(AMed04)

Na perspectiva de alguns dos acadêmicos entrevistados, por sinal aqueles com uma visão mais crítica em relação a realidade, o contexto observado tanto em relação a Medicina como em relação a temática humanização, com as coerências e as contradições, não poderia ser diferente na medida em que reflete a própria cultura do silêncio em que a população brasileira está imersa.

Eu acho que o problema é do brasileiro. Nós somos os culpados porque nós permitimos que a nossa cultura seja essa. Se alguém está errado mas se, por exemplo, eu vou me beneficiar, se eu for amigo dele, eu vou ser conivente com ele. Então essa é a cultura do brasileiro. Por isso que eu acho que é difícil mudar o problema: é cultural. Não mudar pela educação que a gente tem.

(AMed 01) 
Em termos explícitos, a culpabilidade do atendimento não humanizado recaí sobre o outro, que nos depoimentos destes acadêmicos, é o SUS. Não chamam para si ou mesmo para seus colegas a responsabilidade. A falta de criticidade e reflexão destes acadêmicos, na questão da humanização, também se revela pela supremacia da autoridade médica na saúde do outro, neste caso, do outro-paciente. Conforme a fundamentação teórica freireana, esta falta de postura crítico-reflexiva pauta-se, em grande medida, no processo ensino-aprendizagem ${ }^{35,36,79-88}$.

\subsubsection{Sexta Categoria: Ética, direitos e deveres do paciente}

Com relação aos deveres éticos do médico no atendimento ao paciente, o tratar com igualdade e como o próprio médico gostaria de ser tratado foi mencionado como importante. Apesar da postura anteriormente relatada com relação a postura monopolizadora e contra-dialógica no atendimento aos pacientes, os entrevistados referiram, como dever ético, o diálogo aberto e esclarecido com o paciente sobre sua situação e tratamento. Como verdadeira obrigação legal do médico, em esclarecer o paciente sobre a condução clínica, inclusive em casos em que o profissional não tem conhecimento sobre determinado quadro.

Somos todos iguais. Isso é um dever, tratar um paciente como próximo, como você gostaria de ser tratado. Tratar corretamente o próximo, fazer o melhor possível sempre. Mesmo que a parte financeira entrar em questão, tentar fazer pelo menos o melhor possível.

(AMed04) 
O médico tem o dever de explicar para o paciente o que está acontecendo com ele, como que ele pegou aquela doença, o que vai acontecer nos próximos meses, se vai ser favorável ou não. Por que se não for assim não adianta agir que ele vai ficar doente novamente. Principalmente quando você trabalha com comunidades rurais.

(AMed03)

Segundo a lei o médico tem que deixar o paciente informado sobre o que vai fazer, sobre o que ele tem. Tem que deixar a opção para o paciente fazer aquilo, por que ele não é obrigado.

(AMed04)

Muitos dos conflitos acontecem por que médico não soube passar a informação direito, não explicou direito sobre o que ia acontecer com paciente. Ou o paciente recebeu a explicação mas não prestou atenção o que também acontece muito. $O$ paciente tem que cobrar do médico isso e o médico cobrar do paciente.

(AMed 02)

Quando a gente não sabe o diagnostico, não sabe fazer alguma coisa, agente deveria 'abrir o jogo' e admitir que realmente não sabe. Mas pode estudar, ir atrás disso, procurar outro profissional. Tenso pensar isso, não é? É para nós sabermos assim, voltamos ao Deus não somos enquanto médicos. Nós não podemos resolver tudo, não é verdade? Nós temos falha. Então isso é uma questão ética pensar assim.

(AMed04)

Novamente o silencia dos debates com relação a responsabilidade pessoal e/ou da categoria como corpo, denuncia deficiências para uma visão crítico-social ${ }^{35,36,79-88}$.

\subsubsection{Sétima Categoria: prática médica e saúde coletiva}

Os entrevistados apresentam o atendimento privado com melhores perspectivas quando comparado ao atendimento público. Segundo sua percepção, existe demanda menor, melhores profissionais e melhor estrutura física nos serviços 
privados quando comparado ao serviço público, do que depreende a qualidade superior dos primeiros.

No publico o médico vai atender rápido porque tem muita gente e no particular vai atender com cuidado porque quer garantir o seu cliente, o seu paciente. Quer que ele volte, quer fazer uma imagem.

(AMed 01)

Existe bastante diferença entre o atendimento público e o particular. A dificuldade é quantitativa, é a quantidade de gente que tem na rede pública para ser atendida e a quantidade de gente que tem na rede particular. O serviço público é muito mais desorganizado, não pelo próprio serviço mas pela quantidade de pacientes que dependem dele. Acaba tendo que marcar consulta de 4 em 4 meses para o paciente que tu gostaria de ver uma vez por mês, mas é porque se você for ver aquele paciente uma vez por mês você deixa de atender outros.

(AMed 02)

A estrutura é diferente entre o público e o privado. No privado eu acho que acaba sendo mais fácil, com os melhores profissionais, os profissionais mais qualificados, que vão mais para esses centros que Ihes proporcionam melhor estrutura para manter o exercício da profissão. A idéia é ter as coisas agregadas e o serviço particular tem a melhor estrutura e os melhores profissionais.

(AMed05)

Atuação do médico em saúde coletiva foi descrita com dificuldades peculiares a este campo. Dentre as peculiaridades, a questão do enfrentamento de determinantes de saúde originários no entorno sócio-cultural dos pacientes foi demarcada. Os problemas com a infra-estrutura do serviço público de saúde também foram apontados como implicados na atuação do médico em saúde coletiva. Reincidiu a questão da grande demanda de atendimentos clínicos, como um fator limitante das possibilidades para atenção de saúde diferenciada pelos médicos aos pacientes do 
serviço público. A exigência de criatividade como requisito para a efetivação do trabalho do médico foi aludida nas entrevistas.

Na Saúde da Família você, como médico da família, vai atuar até onde pode. Depois entra aquela questão cultural do paciente, estrutura da unidade. As vezes tem que conduzir o paciente para uma estrutura maior, que tenha mais recurso.

(AMed 01)

É absurdo o médico atender 40 pacientes em um dia só. Não tem como. $O$ dever social acaba sendo prejudicado. Nossa atuação acaba sendo limitada a conversa sobre como o paciente se alimenta. A possibilidade de se aprofundar nisso é comprometida e o dever social fica mais nisso em orientação, no sentido da orientação ao paciente.

(AMed 02)

Para atuar em Saúde Coletiva o médico tem que ter bom senso porque em determinado momento não vai poder trabalhar da maneira que quer e vai ter que improvisar, seja em um remédio ou seja improvisar em uma técnica qualquer, ou em uma orientação ou vai inclinar a cama colocando tijolo embaixo. É aquele cara que gosta muito do que faz porque é muito cansativo, vai se estressar muito, vai se privar de muita coisa, tem que gostar e que tenha paciência com o serviço.

(AMed 02)

A perspectiva de que o médico deve entender a complexidade envolvida nesta área da atenção à saúde, que se mostra intersetorial conforme é requisito para o médico atuar em Saúde Coletiva certa articulação com outros setores além da saúde no entendimento destes acadêmicos, de forma que a saúde da comunidade não compete ao médico, mas sim a todos, incluindo governo, prestadores de serviço e a própria comunidade. Esta atuação envolve enfoque em determinantes de saúde, como hábitos de vida, saneamento, alimentação, meio ambiente, tanto quanto ações preventivas e políticas públicas. Não basta a ação do médico. Também existe a 
necessidade de conhecimento sobre a estrutura legal do SUS. Segundo alguns entrevistados, muitos dos problemas do sistema estão relacionados a falta de informação sobre a organização e funcionamento do mesmo, incluindo aí a questão do controle social.

Para atuar em Saúde Coletiva acho que o conhecimento que você tem que saber é uma coisa abrangente. Tem que saber todas as especialidades, por mais que não aprofunde em todos mas tem que saber tudo. Tem que ter noção de tudo que é pra saber, o que está investigando, o que está procurando, saber conduzir todos os procedimentos.

(AMed 01)

A Saúde coletiva é complexa. Envolve o trabalho de saúde e os governamentais e não governamentais. Envolve a própria sociedade. Não é coisa só do médico. O médico orienta, mas é tem as campanhas de saúde. São as pessoas envolvidas pelo governo, algumas campanhas não-governamentais, a própria sociedade se reúne, apresenta, fala dos problemas que interferem na saúde coletiva, na saúde pública. Saúde coletiva é saneamento básico. Se os governantes não constroem, não fazem uma boa estrutura fundamentada e a população não verificam que se pode fazer? Aí se vai orientar para ferver água? Agora, como é que faz com os dejetos, se não tem saneamento na cidade. Isso aí também é saúde coletiva,mas eu acho que pouca coisa é de conceito ao médico.

(AMed04)

Tudo aquilo que rodeia o paciente, o médico tem que saber. Algum problema da sociedade em que ele viva, que se produz na sua família ou na própria sociedade mesmo. O médico tem que orientar, procurar um jeito.

(AMed04)

A saúde coletiva é mais a parte da prevenção. O profissional analisa qual o problema da sociedade, o naquela sociedade pode causar ou vir a causar a doença. E o que pode resolver aquele problema. Não com remédios, não é com cirurgias, é com algumas ações, com medidas de prevenções que são campanhas publicitárias, campanhas de vacinação, saneamento básico adequado. Só envolve isso. Todos fatores conjuntamente contribuem para formação de doenças.

(AMed04) 
Para trabalhar em Saúde Pública é preciso força de vontade. A maioria dos pacientes que vão em postos de saúde, mesmo na saúde da família, já estão doentes. Não dá para trabalhar apenas o método preventivo com esse tipo de pessoa. Deveria interferir na vida da comunidade, da população. Na teoria fica muito bonito. Que deveria ser aplicada mas não é.

(AMed03)

No atendimento individual o objeto é o indivíduo, pois é individual. Eu vejo que na a saúde coletiva, o objeto é, por exemplo, um lixo onde esse indivíduo ou essa gama de indivíduos vivem e a relação desses indivíduos com esse meio onde eles vivem. Ou seja, é aí que se tem que atuar nessa área, de eliminar, de favorecer com que esse lixo não prejudique a coletividade e tão pouco o inverso porque é dessa inter-relação que a coisa vai funcionar.

(AMed05)

Políticas públicas são muito importantes para o médico atuar na área de saúde coletiva. É uma área bastante educativa, que trabalha muito com a educação do povo, que para funcionar tem que haver políticas públicas que a esse profissional condições de ele atingir essa população. Eu vejo dessa forma, eu vejo mais que hoje é a nossa carência: mais política do que profissional.

(AMed05)

Tem algumas regras no sistema de saúde. E o pessoal deixa um pouco bagunçado. Por exemplo o sistema de saúde tem uma hierarquia: primeiro você vai no posto. Se houver necessidade o medico encaminha para o medico mais especializado. É importante conhecer o sistema para você fazer o correto, para você encaminhar e para não sobrecarregar o sistema porque o que agente ver muito sobrecarregar o sistema. Tem muito paciente que não tinha necessidade de estar no hospital. Falta capacitação durante o período da faculdade, ou não foi aprendido, ou se, aprendeu não pôs em prática.

(AMed04)

Tem um lugar que o paciente pode opinar no sistema de saúde. É o conselho de saúde. Lá ele pode tentar mudar aquela situação que ele acha incorreta em determinada região. Ele tem um poder maior.

(AMed 01)

Seguem-se as sínteses dos produtos do grupo focal e das entrevistas individuais com discentes do curso de Medicina. 
Quadro 11: Síntese das perspectivas apresentadas por acadêmicos do último período do curso de Medicina sobre o modelo pedagógico do curso

\begin{tabular}{|c|c|c|}
\hline Produto do Grupo Focal & $\begin{array}{c}\text { Informações das entrevistas semi- } \\
\text { estuturadas }\end{array}$ & Convergências \\
\hline 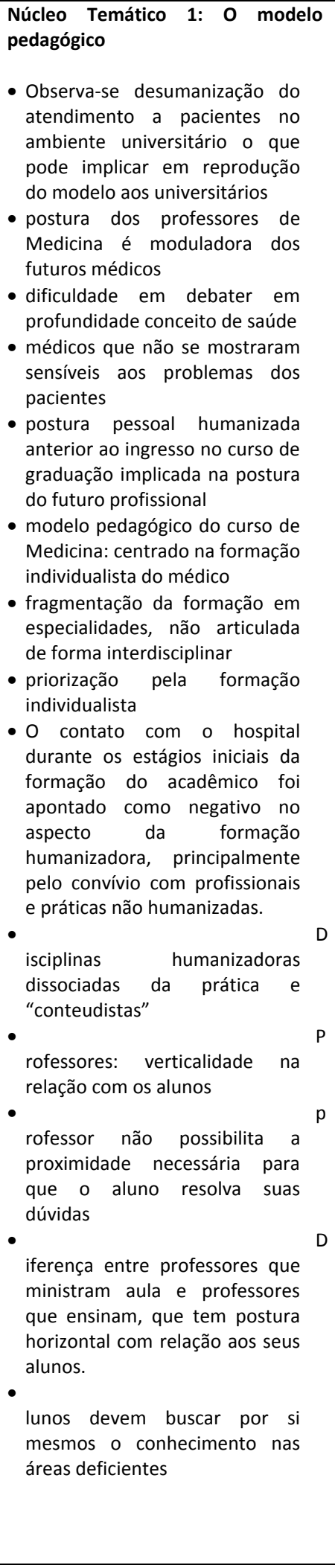 & 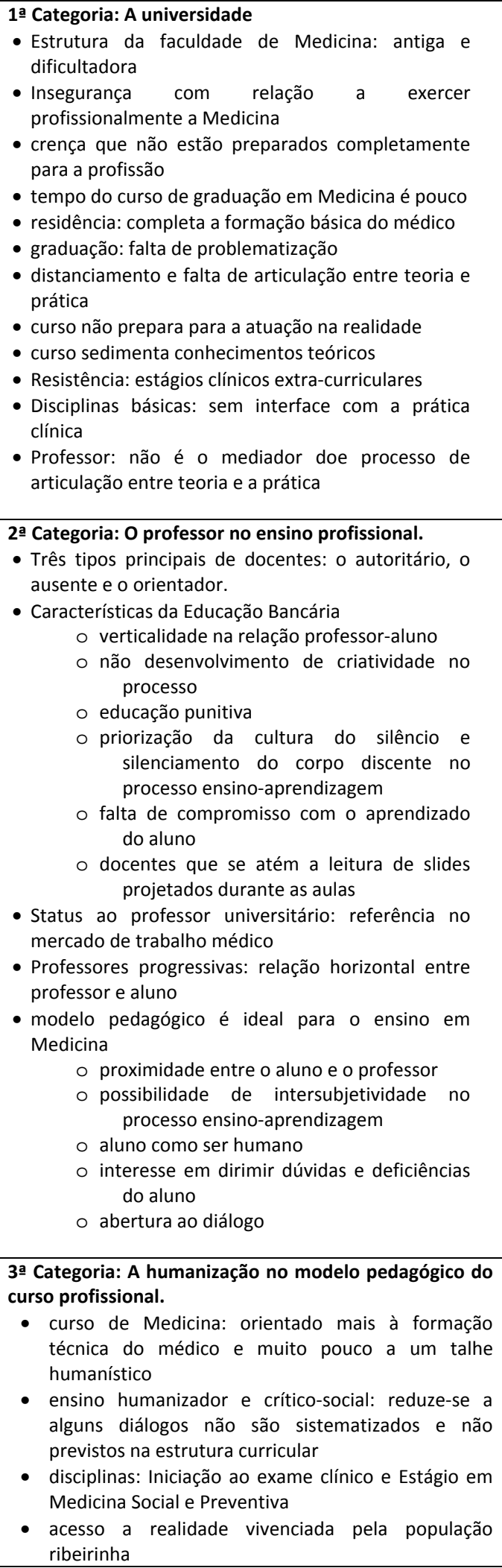 & 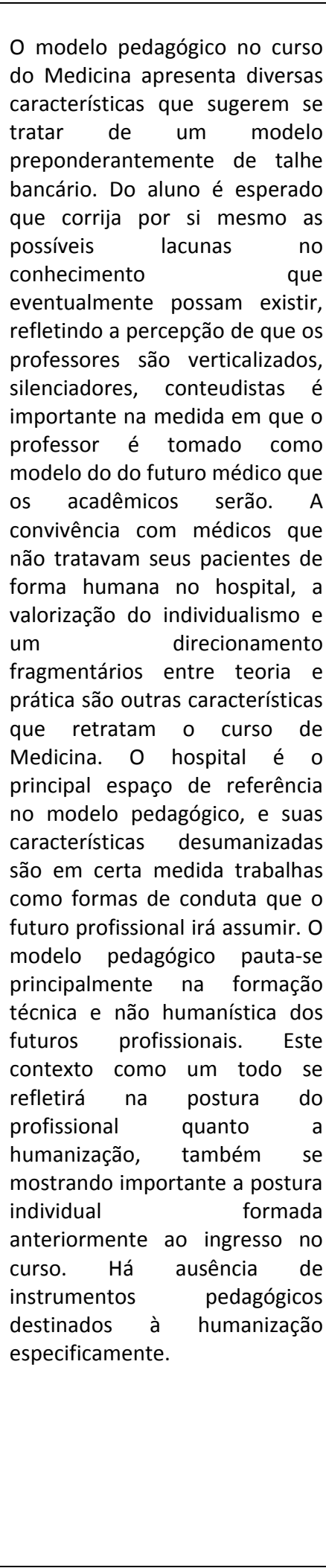 \\
\hline
\end{tabular}


Quadro 12: Síntese das perspectivas apresentadas por acadêmicos do último período do curso de Medicina sobre o modelo pedagógico do curso sobre o médico

\begin{tabular}{|c|c|c|}
\hline Produto do Grupo Focal & Informações nas entrevistas semi-estuturadas & Convergências \\
\hline $\begin{array}{l}\text { Núcleo Temático 2: } \mathbf{0} \text { ser } \\
\text { profissional } \\
\text { - Escolha pelo curso: } \\
\text { convívio com familiares } \\
\text { médicos } \\
\text { - escolha pelo curso: } \\
\text { possibilidade de ascensão } \\
\text { social, manutenção de } \\
\text { alto padrão econômico e } \\
\text { o status } \\
\text { - remuneração acima da } \\
\text { média dos profissionais } \\
\text { de saúde. } \\
\text { - atuação médica é } \\
\text { complexa e honrosa, } \\
\text { condenando a } \\
\text { perspectiva mercantilista } \\
\text { - tipo idealizado de } \\
\text { médico: antigo médico de } \\
\text { família } \\
\text { - profissão caracterizada } \\
\text { por lidar com vidas } \\
\text { humanas } \\
\text { - ato médico tem } \\
\text { significados muito além } \\
\text { da clínica } \\
\text { - postura profissional não } \\
\text { se dá como algo pronto } \\
\text { ou totalmente modulado } \\
\text { pela universidade, mas } \\
\text { sim ressaltam que } \\
\text { características pessoais } \\
\text { influenciam na atuação } \\
\text { médica }\end{array}$ & $\begin{array}{l}\text { 4a Categoria: A humanização na prática do profissional. } \\
\text { - Atendimento humanizado: deve existir diálogo informal com } \\
\text { paciente } \\
\text { - Paciente não é apenas portador de patologia mas ser } \\
\text { humano } \\
\text { - Semelhança entre o médico e o paciente: suscetibilidades } \\
\text { humanas } \\
\text { - Humanização: decorrente do vínculo entre o paciente e o } \\
\text { - } \text { médico } \\
\text { - Tínculo: necessidade de tempo de contato e de aproximação } \\
\text { período de acompanhamento Aproximação é a postura } \\
\text { - horizontalizada do profissional } \\
\text { - Contato entre paciente e médico: relação interpessoal } \\
\text { intorno social do paciente e o médico tem interface } \\
\text { - imagem do médico: destacado tanto em status como em } \\
\text { recursos financeiros } \\
\text { - Sociedade lega a Medicina posição privilegiada } \\
\text { - Status dentro da equipe de saúde em o médico tem } \\
\text { - centralidade em relação aos demais profissionais } \\
\text { - influência do profissional médico em sociedade } \\
\text { - influem as vidas humanas e com grande número de pessoas } \\
\text { - implicações políticas e eleitorais }\end{array}$ & $\begin{array}{l}\text { A ação médica é } \\
\text { caracterizada como o lidar } \\
\text { com a vida humana. A } \\
\text { maneira destes lidar varia na } \\
\text { dependência do modelo } \\
\text { pedagógico e das } \\
\text { características individuais do } \\
\text { profissional. O médico lida } \\
\text { com a complexidade do } \\
\text { paciente e de seu entorno } \\
\text { sócio-cultural no ato clínico, } \\
\text { a despeito deste ser } \\
\text { enfocado apenas na doença } \\
\text { ou não. A Medicina é uma } \\
\text { profissão de status social e } \\
\text { alta hierarquia entre os } \\
\text { profissionais de saúde, tendo } \\
\text { inclusive influência política } \\
\text { em sociedade. }\end{array}$ \\
\hline
\end{tabular}


Quadro 13: Síntese das perspectivas apresentadas por acadêmicos do último período do curso de Medicina sobre o modelo pedagógico do curso aspectos do trabalho do médico e seu relacionamento com o paciente

\begin{tabular}{|c|c|c|}
\hline Produto do Grupo Focal & $\begin{array}{c}\text { Informações entrevistas semi- } \\
\text { estuturadas }\end{array}$ & Convergências \\
\hline 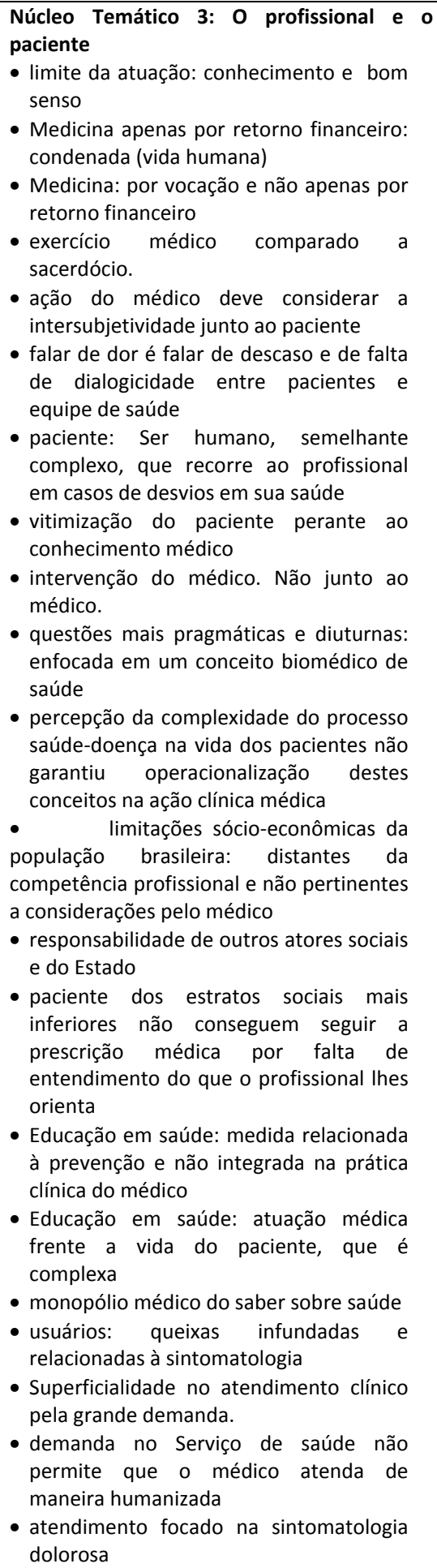 & $\begin{array}{l}\text { 5a Categoria: Desafios à humanização } \\
\text { - Demandas de atendimentos clínicos: } \\
\text { desumanizante } \\
\text { - não permitem que o profissional possa se } \\
\text { dedicar de forma humanizada } \\
\text { - priorização da doença e a ação clínica } \\
\text { reducionista } \\
\text { - dialogicidade do profissional com o } \\
\text { paciente: barreira a efetiva humanização } \\
\text { - médico: monopólio do conhecimento de } \\
\text { saúde } \\
\text { - paciente: deve se submeter a autoridade } \\
\text { médica no tratamento } \\
\text { - conflitos ocasionados pelo diálogo do } \\
\text { médico ineficiente ao entendimento do } \\
\text { paciente } \\
\text { - não existe menção a horizontalidade e } \\
\text { negociação na relação entre as partes } \\
\text { envolvidas no processo } \\
\text { - Problemas são apenas cognitivos do } \\
\text { paciente para com o conhecimento médico } \\
\text { - Postura autoritária mais contundente no } \\
\text { - } \text { - Humviço público de saúde } \\
\text { - paciente não está pagando pelo } \\
\text { atendimento } \\
\text { boándiente de nível superior: relação } \\
\text { horizontal } \\
\text { silêncio em que a população brasileira está } \\
\text { imersa }\end{array}$ & $\begin{array}{l}\text { Medicina não deveria ser } \\
\text { pautada no mercado, dado seu } \\
\text { caráter de lidar com as vidas } \\
\text { humanas. A intersubjetividade } \\
\text { estabelecida entre o médico e o } \\
\text { paciente é fundamental no } \\
\text { processo terapêutico. No entanto } \\
\text { há contradição deste discurso } \\
\text { com a prática do médico que } \\
\text { assume um posicionamento } \\
\text { hierarquizado em relação ao } \\
\text { conhecimento do paciente } \\
\text { entendendo que este deve se } \\
\text { submeter a autoridade médica no } \\
\text { processo terapêutico, } \\
\text { contrário da dialogicidade e } \\
\text { negociação com o paciente e o } \\
\text { entorno sócio-cultural do mesmo. } \\
\text { A postura autoritária não está } \\
\text { implicada apenas com relação ao } \\
\text { paciente mas também com a } \\
\text { equipe, na qual o médico é figura } \\
\text { de centralidade e status na sua } \\
\text { própria compreensão. }\end{array}$ \\
\hline
\end{tabular}


Quadro 14: Síntese das perspectivas apresentadas por acadêmicos do último período do curso de Medicina sobre aspectos do trabalho do médico nos serviços de saúde

\begin{tabular}{|c|c|c|}
\hline Produto Coletivo do Grupo Focal & $\begin{array}{c}\text { Informações das entrevistas semi- } \\
\text { estuturadas }\end{array}$ & Convergências \\
\hline 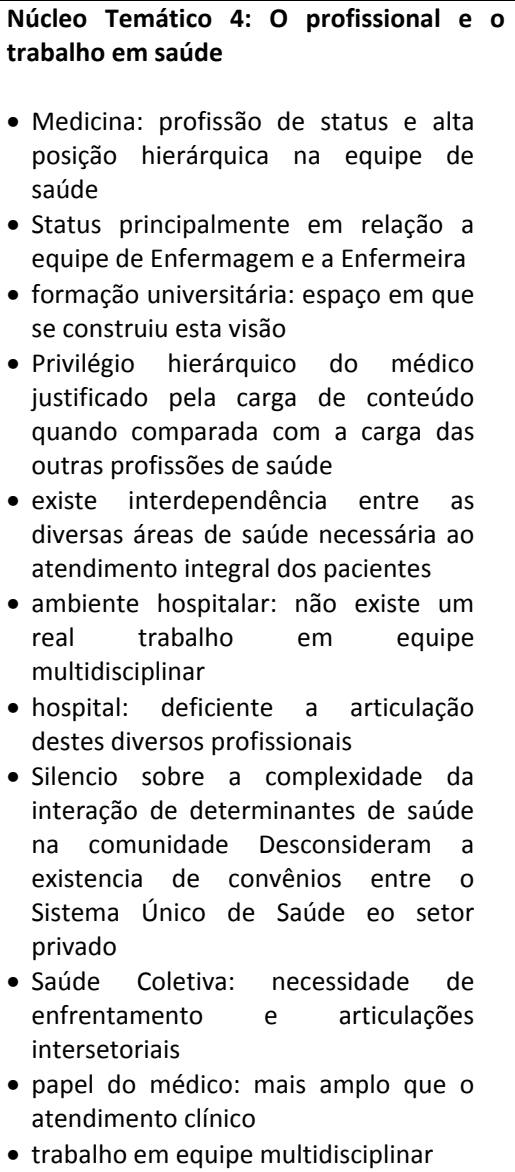 & $\begin{array}{l}\text { 7a Categoria: A prática profissional e saúde coletiva } \\
\text {-Atendimento privado melhor do que o } \\
\text { atendimento público } \\
\text { - Atendimento privado: demanda menor, } \\
\text { melhores profissionais e melhor estrutura física } \\
\text { - Médico em saúde coletiva: dificuldades } \\
\text { peculiares a este campo } \\
\text { - Dificuldade para enfrentamento de } \\
\text { determinantes de saúde } \\
\text {-Dificuldade para enfrentamento do entorno } \\
\text { sócio-cultural dos pacientes } \\
\text { - Problemas com a infra-estrutura do serviço } \\
\text { público de saúde } \\
\text { - grande demanda de atendimentos clínicos } \\
\text { - exigência de criatividade como requisito } \\
\text { - médico deve atuar junto a complexidade } \\
\text { envolvida na àrea } \\
\text { - problemas com intersetorialidade } \\
\text { - Saúde Coletiva: necessidade de articulação com } \\
\text { outros setores além da saúde } \\
\text { - governo, prestadores de serviço e a própria } \\
\text { comunidade Não basta a ação do médico } \\
\text { - Necessidade de conhecimento sobre a } \\
\text { estrutura legal do Sistema Único de Saúde } \\
\text { - questão do controle social }\end{array}$ & $\begin{array}{l}\text { O médico é um profissional } \\
\text { hierarquicamente superior aos } \\
\text { demais dado seu conhecimento } \\
\text { maior sobre as questões de } \\
\text { saúde. Há contradição entre a } \\
\text { prática e a teoria, na medida em } \\
\text { que este posicionamento retrata } \\
\text { a prática, mas em teoria o } \\
\text { trabalho em equipe é essencial, } \\
\text { já que todos os profissionais tem } \\
\text { importância na atenção. Uma } \\
\text { evidência desta necessidade é a } \\
\text { prática da equipe hospitalar que, } \\
\text { na realidade não trabalha em } \\
\text { equipe, mas sim em sub- } \\
\text { especialidades no mesmo } \\
\text { paciente. Em saúde coletiva esta } \\
\text { necessidade é mais contundente, } \\
\text { dado que o médico não apenas } \\
\text { deve se articular aos demais } \\
\text { profissionais de saúde como } \\
\text { também deve promover on setores não } \\
\text { articulação com sua } \\
\text { apenas da saúde, enfocando sua } \\
\text { atuação na intersetorialidade. } \\
\text { Mas isso não acontece na prática. }\end{array}$ \\
\hline
\end{tabular}




\subsection{A perspectiva dos acadêmicos de Odontologia}

\subsubsection{O produto do Grupo focal de acadêmicos de Odontologia}

\subsubsection{Núcleo Temático 1: Sobre o modelo pedagógico no ensino de Odontologia}

O professor é apresentado pelo grupo como principal modulador da relação com o aluno, existindo aqueles que se mostram mais autoritários e verticalizados e que não permitem diálogo nem mesmo quando estão errados e os alunos corretos, segundo os acadêmicos. Ao mesmo tempo existem aqueles professores próximos e abertos, influenciando positivamente os futuros odontólogos.

A relação sempre depende do professor.

Já aconteceu de eu fazer um procedimento que eu estava certa e o professor quis que eu fizesse do jeito dele.

Às vezes acontece de o professor aprender coisas, por exemplo, de prótese, por uma escola. Para ele o certo é aquilo. Mas cada professor tem sua visão não só prótese mais dentística, de endodontia. Ás vezes eles confundem a cabeça do aluno.

A gente tem professores que são grandes amigos. As pessoas sentem a diferença tratamento. Acho que isso influencia totalmente e que são professores que vão me influenciar a vida inteira em que dentista eu vou ser.

A relação distante entre professor e aluno se mostrou como referência para este grupo de como conduzir a relação odontólogo-paciente durante sua prática clínica.

Eu procuro manter aquele negocio parecido com o paciente: mantenho um bom convívio com os professores, mas uma relação profissional. Tem professor que eu me dou muito bem, mas nem por isso eu vou à casa dele ou chamo ele de algum apelido. 
$\mathrm{Na}$ percepção destes acadêmicos, existem professores que não estão preocupados em ensinar seus alunos, inclusive não ensinando justamente por estes serem seus futuros concorrentes.

Procuro 'sugar' o professor ao máximo. Só que eu acho que tem muito professor que vê o aluno como concorrente profissional.

Eu já percebi muito isso em vários professores que se interessam mais em criticar o aluno no sentido de ver o procedimento que o aluno esta fazendo errado do que ensinar de verdade.

Por que ele não chega para o aluno e diz 'isso que você está fazendo não deve ser assim'. Ele não ensina para o aluno o correto.

Eles se preocupam mais em dar uma nota baixa na pratica, do que chegar e dizer 'olha, a tua nota foi assim porque isso e aquilo, o procedimento está errado, tem que melhora nisso'.

Com relação à matriz curricular, diversas disciplinas se empreenderam a trabalhar o entendimento do ser humano para os futuros odontólogos.

Nós tivemos psicologia aplicada a Odontologia.

Das que entendem o ser humano, tivemos odontopediatria também.

Eu acho odontopediatria é a disciplina que mais ajudou a entender o ser humano.

Eu acho que odontopediatria ajuda a entender mais porque lida com criança.

Aprendemos a entender o ser humano em Odontologia social.

Em Odontologia social a gente aprende a lidar com varias faixas etárias, com as classes sociais. 
O grupo de acadêmicos de Odontologia apresentou claros problemas em debater as questões, em particular as que se referiam ao modelo pedagógico, como se esta fosse uma questão menor frente a capacitação técnica dos mesmos. Isso corrobora com o pensamento sobre na necessidade de reformular o modelo pedagógico, uma vez que, se estes acadêmicos acreditam não haver importância significativa no debate a cerca da própria formação, a que se considerar que esta postura poderá ser mantida no que se refere à prática profissional posterior à graduação. E, em estando no PSF, tal postura desumanizadora e acrítica, na concepção freireana ${ }^{35,36,79-88}$, poderá dificultar o desenvolvimento de sua atuação em consonância com este Programa.

\subsubsection{Núcleo Temático 2: Sobre o ser odontólogo}

Assim como para os acadêmicos de Enfermagem e de Medicina, a presença de familiares e outros conhecidos odontólogos se mostraram componentes importantes na opção pelo curso de Odontologia.

Escolhi Odontologia porque eu já tinha um contato prévio. Meu primo é formado em Odontologia. Achava interessante a parte de reabilitação. A parte estética foi o que me chamou atenção.

Gostava de ir à minha dentista e gostava dela. Conforme o tempo foi passando na faculdade eu percebi que era realmente o que eu queria mesmo. Acho que foi uma decisão pela vivencia. Eu queria aquilo mas só descobri que queria mesmo quando comecei a cursar, assim com tem pessoa que descobriu no curso que não queria e abandonou. 
Outro fator importante na deliberação pelo curso para estes acadêmicos foi o fato de se tratar de uma profissão do campo da saúde.

A opção por Odontologia veio pela questão que não somente você cuida da saúde quando se trata de Medicina. Você também pode cuidar da saúde quando você é odontólogo. Eu me interesso por isso e achei interessante fazer Odontologia por isso.

Minha opção por Odontologia foi por estar numa área que eu sempre fui interessada: a área biológica. Também é interessante saúde bucal. Muitas pessoas não valorizam essa parte e deixam a saúde bucal de lado. É sempre importante prevenção para essa área da saúde.

O terceiro fator de influência talvez seja o mais interessante e impar, quando comparado com o que foi apresentado pelo grupo de acadêmicos de Enfermagem e pelo grupo de acadêmicos de Medicina. Para os acadêmicos de Odontologia, a opção pelo curso traduz a busca por uma atividade tipicamente de profissional liberal, cujo controle sobre o próprio processo de trabalho é a característica que mais se delimitou nas falas.

Eu decidi pela Odontologia porque queria uma profissão que tivesse autonomia.

Por um tempo eu sei que a gente vai ter que trabalhar sendo empregado de alguém, mas a longo prazo não.

Quero poder mandar em mim mesma, poder ser minha chefe, poder decidir os horários.

Pensei em Odontologia, Medicina e direito. Como me acho delicada, até certo ponto perfeccionista. Também quero ser minha patrona. Só me enquadrei na área de Odontologia. 
Ser dentista é ser um profissional autônomo que vai tratar da saúde bucal.

Ainda neste tom de primazia pela prática privada e liberal, para estes acadêmicos o setor mais representativo da profissão é a estética dental, justificado que este campo permite auto-valorização do paciente. Ao mesmo tempo, é apresentado que a Odontologia passa por um momento de mudanças, em que os odontólogos são cada vez mais conclamados as ações reabilitadoras funcionais e de prevenção. Apesar de que os atos preventivos são aludidos como forma de preservação das ações estéticas realizadas e não como ato anterior ao aparecimento das afecções bucais.

A Odontologia como profissão significa você poder restabelecer a estética e também, muitas vezes, a função do paciente.

É muito gratificante você ver o paciente chegar com a auto estima baixa, totalmente desestimulado para conseguir emprego, para tocar seu relacionamento adiante e quando ele percebe que você consegue restabelecer a saúde bucal e proporcionar a estética, um sorriso agradável... Modifica também a forma de enxergar a vida como um todo. $\mathrm{O}$ paciente fica mais receptivo e mais feliz.

Tem paciente que chega com o processo de mastigação impossibilitando comer determinados alimentos pela falta de dentes. A gente também possibilita a devolução do que ele perdeu.

Hoje em dia o dentista tem que estar voltado muito para prevenção, porque nos primórdios eles só se preocupavam com o tratamento, com o paciente no consultório com dor e queria resolver aquilo e pronto. Não interessa você fazer apenas o tratamento. Você tem que usar fio dental e técnica de escovação, motivar o paciente para que consiga um padrão de saúde oral, não só fazer o tratamento.

Digamos que tenha que fazer um tratamento maior, até com maior ônus para o paciente, a gente acaba tendo esse papel de educador 
também para prevenção das doenças da cavidade oral. Por que se não o tratamento é perdido. Precisa-se prevenir.

Durante as discussões emergiu a perspectiva de que o odontólogo apresenta monopólio sobre os conhecimentos de saúde bucal não apenas com relação aos pacientes, mas também em relação a outros profissionais de saúde.

As pessoas têm que encarar o tratamento odontológico como um tratamento médico, que se preocupa periodicamente em ir para saber se está tudo bem. Ele tem que se conscientizar que essa preocupação também deve existir em relação ao dentista.

Se o paciente vai ao medico... mas o médico não olha a boca também. Então não vai saber se ele tem alguma coisa. Se não for ao dentista nunca vai ficar sabendo.

A perspectiva da profissão, com cunho eminentemente mercadológico, verticalizado em relação ao paciente e suas demandas em Odontologia, faz refletir sobre o modelo pedagógico que ensina a prática liberal privada e desumanizadora, ao invés de se pautar na orientação à crítica e a reflexão, construindo caminhos para o odontólogo como agente de mudanças, reflexões frente ao universo freireano ${ }^{35,36,79-88}$.

\subsubsection{Núcleo Temático 3: Sobre a relação Odontólogo-Paciente}

O termo 'humanização' foi utilizado exclusivamente como sinônimo de acolhimento por parte do grupo de acadêmicos de Odontologia, não sendo aludida 
empatia nos discursos. $\mathrm{O}$ atendimento de grande número de pacientes em um mesmo período foi considerado desumanizador do profissional frente aos pacientes.

A gente vê o paciente como ser humano.

Humanização é você não tratar o paciente apenas de uma forma técnica. O paciente chegou e você, às vezes, não dá nem um bom dia. Você não pergunta como é que ele esta, porque ele veio te procurar. Você vai atender de uma forma técnica, 'senta, abra a boca'. Você olha apenas para o dente e esquece da saúde como um todo, esquece da saúde bucal.

Para mim humanização é isso: você trata o paciente com respeito, como pessoa, dando a devida atenção, a devida educação, as devidas informações para cada tipo de paciente adequar ao que ele necessita.

O nosso próprio trabalho é uma forma de humanização, de estar ajudando a promover a saúde para o paciente.

Por exemplo: em uma manhã, em um curto período de tempo, o paciente senta e você olha a boca. Depois acaba o procedimento. Quando um levanta, você já pega outro e é assim se atende, de uma forma muito mecânica. Isso faz perder a sua humanidade.

Saúde Coletiva foi apresentada como uma avaliação da saúde da comunidade, prioritária para o trabalho em saúde. Neste ínterim, a saúde foi definida como resultado da interação de determinantes e não por simples relações de causalidade pautada em perspectiva biomédica. A aplicabilidade da Saúde Coletiva foi uma informação com grande reincidência, sugerindo que estes acadêmicos apresentem aporte teórico, conforme a sustentação do debate conforme se deu durante a realização do grupo focal, de forma muito mais embasada em conhecimentos teóricos do que o mesmo debate nos grupos focais das outras formações. 
Saúde Coletiva avalia a saúde da sociedade, avalia a saúde da população em geral.

Saúde coletiva é pensar no coletivo e nos programas de saúde publica, como o SUS e outros.

É ver os acometimentos de saúde bucal para cada classe social, de cada região.

É entender a saúde para os bairros, para você saber os enfoques daquela comunidade. Na verdade a saúde coletiva mostra a realidade mesmo na região, porque as vezes você trabalha no consultório particular e fica meio alheio a essa realidade dos pacientes que vão chegar para você. Então saúde coletiva mostra justamente o todo.

Em saúde na comunidade a gente vai ter que observar os mesmos critérios de saúde geral e bucal, para que se faça alguma coisa para melhoria da comunidade. Você tem que fazer primeiro fazer uma avaliação, um estudo para verificar o que está mais precário e o que pode ser feito.

Podem ser questões ambientais ou socioeconômicos que estão interferindo para que, por exemplo, o índice de cárie seja elevada.

A faixa etária da população interfere na saúde da comunidade.

Dois entendimentos paradoxais são recorrentes no discurso do grupo de acadêmicos de Odontologia. Existe a perspectiva de que o todo social e os outros aspectos, que não remetem diretamente à prática clínica, interferem na saúde do indivíduo e que isso tem importância para o odontólogo. Em paralelo, o paciente é pensado como o comprador dos serviços, alguém que tem responsabilidade direta por deixar de recorrer ao profissional e de ter cuidados com sua saúde bucal, perspectiva que não leva em consideração questões sócio-econômicas. A postura do profissional emerge em uma perspectiva distante e verticalizada em relação ao paciente, inclusive priorizando o silêncio do mesmo durante o contato com o odontólogo, para o qual não 
é pertinente o conhecimento das relações complexas da vida do paciente. Atuar em um contato amplo e próximo é tarefa legada aos psicólogos, segundo este grupo.

$\mathrm{Na}$ faculdade a gente aprende como lidar com o paciente em todos os aspectos: social, psicológico. Acho que a gente e bem instruído para isso eu não sei se todo mundo vai sair daqui praticando todas as instruções que foram fornecidas. Se vão ser aplicadas futuramente vai depender da personalidade de cada um que passou pela faculdade, do caráter pessoal.

Todos os aspectos: físicos, emocional, psicológico... tudo entra no exame anamnese... até se o paciente é nervoso, se ele tem medo de dentista.

Tem paciente que deixa a boca de lado. Tem gente que chega que sabe e que tem uma raiz infeccionada. Se tiver mais idade pode ter um problema cardíaco, pode ter um problema no coração.

Eu acho que cada paciente é um individuo único. Tu vai tratar conforme aquele paciente é. Vamos supor que a gente está na odontopediatria atendendo criança. Eu não vou trata a criança como adulto. Vai depender da criança: tem aquela criança que não é tola, então trato ela de forma normal. Já tem aquela criança que a gente vai ter que ser mais rude, mais rígida, porque ela é muito tola e não sabe diferenciar.

A gente procura manter um vinculo profissional, porque o paciente vai muitas vezes ao dentista e pensa que é psicólogo. Ele quer conversar e é meio difícil tratar com a pessoa falando. Ou ela fala sem parar ou você faz o tratamento.

O dentista não tem que conversar. Não tem que levar o tratamento para a intimidade.

Se o paciente falar 'ah, eu to com uma dor de cabeça por que hoje eu briguei com o meu marido' acho que pode até falar 'briguei com o meu marido'. Isso é importante. Vai interferir no tratamento porque eu sei que ela não vai ter paciência de ficar uma hora na cadeira. Mas se ela quiser dar detalhes da vida com o marido ai não pode.

O estado psicológico e mental interfere na saúde do indivíduo. Imagine se uma pessoa esta com estado sistêmico com tudo ok. Se a saúde mentalmente esta prejudicada, com o psicológico abalado vai influenciar diretamente nos outros aspectos da saúde. 
O odontólogo tem que saber lidar com o paciente mas sem se envolver. Para o paciente não ficar indo até onde é a sua casa.

Tem que haver uma relação profissional entre o dentista e o paciente. A gente procura evitar se envolver, mas a gente acaba com um paciente.

Como já apresentado, a perspectiva liberal e mercantilista na prestação de serviços pelo odontólogo pode ser nitidamente percebida, durante diversos momentos do diálogo com este grupo. No entanto, o momento que mais chamou a atenção foi quando da definição do termo 'paciente'. Paciente foi conceituado como o comprador do serviço do odontólogo que lhe prestará para o restabelecimento de sua saúde oral.

O paciente é alguém que eu vou vender o meu serviço.

Alguém que eu vou atender e que está doente.

Alguém com quem você vai estabelecer uma troca: ele precisa e vou receber pelos meus serviços prestados.

O paciente é uma pessoa que a gente vai lidar, dar uma atenção voltada a saúde bucal, para saúde sistêmica e que a gente vai ter um retorno financeiro.

Em diversos momentos registra-se um pensamento de culpabilidade do paciente e de sua condição econômica em situações em que a população não recorre ao odontólogo e passa a ter afecções orais. Este pensamento reincide, como se independente dos conceitos de complexidade da saúde do individuo que foram aludidos em momentos anteriores da discussão. Os problemas em saúde bucal das pessoas de estratos socioeconômicos menos favorecidos são originados pela falta de 
conhecimento, segundo o grupo, desconsiderando a situação de exclusão e iniqüidade a que estas parcelas populacionais estão condicionadas, por processos históricos, políticos e econômicos, que se refletem em toda a vida do cidadão, inclusive nos aspectos de saúde e, nestes, na saúde bucal.

A condição que mais interfere na prática odontológica é a condição monetária.

Tem gente que não vai ao dentista de 6 meses em 6 meses fazer fluorterapia por falta de dinheiro.

A principal necessidade da população brasileira é motivação para prevenção, que a pessoa tem que escovar o dente como prevenção, que tem que ir ao dentista não apenas quando tiver com dor, que ele tem que ir ao dentista fazer profilaxia para prevenir, para não ter cárie, doença periodontal. Não só procurar o tratamento.

Quando você vê um paciente com falta de higiene oral você também nota a falta de higiene em outras partes do corpo. Você pode como profissional da saúde pode ajudar o paciente dando um toque nesse sentido que melhora a saúde geral dele.

Os pacientes de uma classe menos favorecida apresentam condições patológicas mais serias e mais difíceis de serem tratadas. Tudo é mais complicado, porque como eles não têm conhecimento. Tem muito paciente que não procura o dentista. Só procura quando está em uma condição extrema. Diferente de um que tem um nível de conhecimento melhor.

O discurso sobre a fragilidade de conhecimento dos estratos sócio-econômicos menos favorecidos incide também na temática da Educação para Saúde. O ensino ministrado em instituições privadas, para os estratos sócio-econômicos privilegiados, propicia conhecimentos que garantem um bom padrão de higiene oral; enquanto que o trabalho educativo em saúde junto aos estratos menos favorecidos é dificultoso, segundo a perspectiva destes acadêmicos de Odontologia. 
A própria educação do paciente interfere na prática odontológica.

Na escola particular ensinam tudo de higiene oral. Geralmente não acontece nas escolas publicas então da própria criação e mesmo ambiente familiar da criança interferem na saúde da criança.

O dentista não trata só a saúde bucal. Muitas vezes a gente estabelece a saúde geral do paciente porque ele já chega não tem cuidado com a boca quanto mais com restante. A gente sempre fala 'olha, tem que ter uma higiene melhor'. Com isso ele começa higienizar não só a boca, mas também o restante do corpo. A gente alerta as mães das crianças que vem para serem tratadas na universidade para uma melhor higiene da criança, não só no estabelecimento da saúde bucal.

A gente explica e eles acham que estamos enrolando. Não entendem que, por exemplo, mesmo sem nenhuma cárie podem perder todos os dentes porque não escovaram, não removeram a placa. Até para explicar o que é placa você tem que falar 'sujeirinha' no dente.

Isso acontece muito na odontopediatria. Normalmente a criança que tem a cavidade bucal bem precária e você compara com os pais. Normalmente tem o mesmo problema de falta de higiene. 0 individuo tem importância em todo ambiente que ele vive.

A discussão referente a questão da dor do paciente restringiu-se ao entendimento como um fenômeno biológico e emergencial, relacionado ao dia-a-dia do odontólogo em sua prática clínica, não havendo qualquer referência a outros tipos ou dimensões da dor.

Dor para o dentista é considerada como urgência. E ela está presente todos os dias na vida do dentista.

Quando o paciente chega com dor, por mais que tenha outros procedimentos mais importantes a gente procura primeiro sana-la.

A dor é o que mais perturba o paciente tanto de forma física como emocional. 
A contradição com relação a uma perspectiva crítico social na atuação do odontólogo evidencia-se nos depoimentos deste grupo de acadêmicos de Odontologia, na medida em que o grupo valoriza a utilização da prática odontológica com fins eleitorais. Cabe ressaltar que as práticas descritas infringem diretamente a legislação vigente que trata da conduta ética odontológica. Além das implicações em termos de construção de cidadania e de empoderamento das populações menos favorecidas.

Acho interessante trabalhar na comunidade. Eu tenho vontade de participar daquelas ações de eleição. Tudo bem que se está vendendo voto, mas é uma coisa que eu acho até interessante para o profissional, só para ir lá, fazer extração seriada nas crianças no final de semana.

Essa coisa de eleição para o paciente é uma vantagem, por que ele não tem gasto e vai receber o tratamento.

Acho que agir nestas ações durante as eleições além de ser interessante é importante para o nosso crescimento pessoal e para a população também.

O problema é que vai realizar muito procedimento mas não vai dar tempo de promover saúde, de orientar a escovar para prevenir.

Apesar do conhecimento a cerca de conceitos próprios da Saúde Coletiva, quando a questão remete a prática do odontólogo, os acadêmicos apresentaram uma perspectiva contraditória a primeira, dado que o cunho mercadológico, centrado no odontólogo, prevalece. Estas contradições são eminentemente desumanizadoras, conforme o pensamento freireano ${ }^{35,36,79-88}$. 


\subsubsection{Núcleo Temático 4: Sobre o Odontólogo e trabalho no serviço de saúde}

Estes acadêmicos apresentam uma visão ampla sobre a saúde dos indivíduos, mencionando que o profissional não pode se limitar a priorização das especialidades, mas sim que o indivíduo deva ser encarado de maneira sistêmica, em que cada parte se articula com o todo. Denunciam que muitos odontólogos não apresentam essa visão e que isso é um prejuízo ao trabalho em saúde, na medida em que diversas patologias sistêmicas têm manifestações orais identificáveis pelos odontólogos. As equipes multiprofissionais são espaços privilegiados de saúde, na visão destes acadêmicos, sobressaltando estratégias como a Saúde da Família em que a organização do serviço já prevê essa realidade.

Você pode ver saúde de uma forma localizada, mas a saúde geral do individuo vai desde a cabeça deles até os pés. Nós somos bem orientados no curso a ver o paciente como um todo, não somente a cavidade oral. Muitas vezes alguns profissionais vêem o paciente sentado na cadeira odontológica e só olham para aquela área que ele é especialista. Isso não é correto. É lógico que ele tem que dar uma atenção maior aquela área, mas no inicio, na parte inicial do procedimento ele tem que ver tudo.

O odontólogo não só trata na parte da saúde bucal como também sistêmica, psicológica.

O odontólogo tem como identificar também pela boca alguma outra doença sistêmica e encaminhar o paciente para o médico. Isso também é importante.

O odontólogo também deve ser responsável pelo paciente como um todo e se preocupar com o diagnostico seja da área odontológica ou da área medica. Muitas manifestações sistêmicas aparecem por intermédio da cavidade bucal. Ser responsável pelo paciente como um todo é estar se preocupando com seu bem estar físico, com seu bem estar geral.

O dentista atua na saúde bucal principalmente, mas também na saúde geral do paciente. Identifica quando há algo de errado no 
paciente, mas encaminha sempre para o medico tratar. $\mathrm{O}$ dentista não trata.

Existem algumas doenças que o dentista pode identificar como AIDS, que tem uma manifestação oral. Assim que ele ajuda o paciente.

Se tiver uma manifestação oral e o dentista for realmente capacitado ele vai saber se o paciente é portador e encaminha para fazer exames.

Até o saneamento básico conta. Se onde o paciente mora não tem saneamento básico influencia no tratamento odontológico.

Acho que um profissional de saúde é alguém que de alguma forma vai estar ali na sociedade ajudando as pessoas a se cuidarem a terem saúde.

O profissional da saúde, seja ele enfermeiro, medico, dentista, fisioterapeuta esta ali para que tenha um mundo melhor, uma expectativa de vida maior para a população humana.

Não só o medico é profissional de saúde. O odontólogo também é. A gente vê isso na equipe de saúde da família. Os profissionais que estão junto do medico são o dentista e o enfermeiro. 0 fisioterapeuta agora esta entrando.

Principalmente nos programas de saúde da família a relação entre dentista e médico é uma relação bem legal porque é uma coisa que não interfere muito na área de atuação de cada um. É diferente da disputa do cirurgião de cabeça e pescoço com o cirurgião bucomaxilofacial pela área de atuação. É uma relação bem amigável com o médico, apesar do enfermeiro que, querendo ou não, se sente inferior ao medico que se sente superior. É uma relação mais complicada. Para mim é diferente a relação entre médico e dentista.

A interação entre a equipe é importante para o paciente, também na forma de dinamizar os procedimentos e o campo de atuação. Se você tem um médico e um dentista a sua disposição o resultado final vai ser bem melhor do que se tivesse só o médico que não vai ter uma atuação frente a saúde bucal ou só um dentista alienado que só se preocupa com a saúde bucal. Acho que é importante essa interação, é uma dinâmica de proporcionar saúde.

Esta perspectiva de atuação em equipe se mostrou ainda mais contundente quando a discussão foi encaminhada para a Saúde pública em que, segundo o grupo, 
todos os profissionais da equipe de saúde, a comunidade e até mesmo os indivíduos em suas relações pessoais tem participação no processo de saúde da comunidade.

A Saúde publica compete a todo profissional de saúde. O dentista, médico, enfermeiro e todo profissional da saúde tem um papel nesse processo de saúde.

Até mesmo a assistência comunitária compete. Às vezes não precisa ser nem um médico ou um dentista, mas pode ser até um voluntário.

Um agente comunitário que estudou, que se preocupa com a comunidade dele, pode melhorar as condições. Ele também é responsável pela saúde coletiva.

Cada pessoa também é responsável pela saúde dele e de quem está próximo. Ele pode estar influenciando positivamente ou negativamente.

Reincide a contradição nos discursos, entre o que conceituam como ideal de prática e a real prática do odontólogo, apontando para o encaminhamento da fragmentação/desarticulação entre teoria e prática, que conduz a falta de consciência e pensamento crítico social, conforme o marco teórico freireano ${ }^{35,36,79-88}$.

\subsection{2 produto das entrevistas individuais de acadêmicos de Odontologia}

\subsubsection{Primeira Categoria: a Universidade}

Os acadêmicos do curso de Odontologia apresentaram como a principal lacuna durante sua formação universitária a falta de recursos materiais necessários para a formação do Odontólogo. Recursos que se resumem a materiais dentários necessários 
a ação clínica odontológica, materiais de ponta em termos tecnológicos, não sendo mencionada qualquer outra ausência que prejudicasse seus desenvolvimentos como futuros odontólogos.

Faltava um pouco de material odontológico. Com certeza nada que prejudique $o$ atendimento do paciente. A gente sempre procura fazer o melhor possível e tudo feito com aquele material que é mais caro com aquele outro que o custo é menor. Não vai ficar tão bom quanto aquele que é mais caro mas atende as necessidades do paciente.

(AOdo 01)

A gente tinha que comprar alguns materiais para clinicar.

(AOdo 03)

Chegava a gastar trinta e cinco reais por cirurgia que eu realizava na faculdade.

(AOdo 04)

Detalhe interessante, no pensamento dos acadêmicos de Odontologia a faculdade Ihes capacitou teoricamente, o que seria sua função. Com a prática clínica, depois de graduados, haverá o aperfeiçoamento da destreza clínica, dado que apontam que o tempo de exercício profissional é um requisito para o desenvolvimento pleno da profissão. Outra informação relevante é que o curso capacita para a atividade de consultório particular, sendo deficiente na formação para o atendimento em Saúde Coletiva.

Me sinto capacidada tecnicamente sim. Achoque a faculdade dá uma estrutura boa para o aluno com as aulas, o restante é pratica, mas tecnicamente a gente tem orientação suficiente para isso.

(AOdo 04)

Não me acho preparada para atender no serviço público porque o que a gente tem de material que a faculdade proporciona para gente 
não vou estar encontrando em posto de saúde. Não faço uma restauração de resina aqui sem o isolamento absoluto, que deixa o dente sem saliva e sem contaminação nenhuma. Lá no serviço publico de saúde não tem material para isolamento absoluto, você tem que fazer uma restauração de resina com isolamento relativo só com um algodãozinho ali do lado. É uma coisa que eu não estou preparada. Nunca fiz uma restauração de resina com isolamento relativo porque a faculdade não permite. Como é que eu vou fazer depois de formada lá no serviço publico.

(AOdo 03)

Acho que a partir de agora a gente tem o conhecimento teórico. A partir de agora é só a prática. A gente tem que consolidar o nosso conhecimento na prática. A faculdade não ensina tudo. Nossa profissão é muito prática. No decorrer do exercício da nossa profissão a gente vai aprender bastante.

(AOdo 01)

Tecnicamente a faculdade ensina. Agora, o aprimoramento vem com o tempo e com a pratica da clinica. A gente aprende com a orientação dos professores. A gente não faz nada sozinho, tem um preparo. $O$ conhecimento técnico-cientifico a gente tem.

(AOdo 04)

O curso de Odontologia a prepara em todos os aspectos e não somente em atender o paciente e enxergar só os problemas bucais, ser só pratico, um técnico, mas procura nos envolver e nos passar que somos responsáveis pela comunidade, pelo paciente. Acho que a gente recebe formação para isso, preparo para lidar com o consultório particular. A gente recebe aqui na formação, a formação teórica. Procuram adequar as informações teóricas a realidade da nossa população, a realidade do Brasil, o que é mais comum aparecer em consultório, o que é mais prevalente dos tratamentos. Falam de tudo mas adequam ao que a gente tem mais oportunidade de achar e transferem da teoria para pratica tudo que a gente aprendeu.

(AOdo 02)

Na percepção destes acadêmicos do curso de Odontologia, há divergências entre a teoria universitária e a prática odontológica fora da universidade, no sentido de que os odontólogos não aplicam todos os cuidados que são preconizados no meio universitário, principalmente no que se refere às questões de biossegurança no ato clínico, mesmo no atendimento particular. 
Existem técnicas que nenhum cirurgião dentista aplicava antes de eu entrar na universidade. Não sei se aplicam agora, mas, pelo menos a questão de biossegurança acho que a faculdade fornece muita instrução com relação ao cuidado do paciente, para evitar a contaminação profissinal-paciente e acho que a maioria dos dentistas não fazem. Por exemplo colocar isolamento absoluto para fazer uma restauração. Mesmo em clinica particular nunca colocaram isolamento absoluto em mim.

(AOdo 04)

A gente veio perceber que $o$ atendimento que tinhas antes de entrar na faculdade do que prestamos é meio diferente. Por exemplo a questão do isolamento absoluto. Eu nunca tinha ouvido falar na minha vida. Não sabia que se usava isso, que existia e era questão de biosegurança. Acho que com a prática e com atendimento é que a gente é obrigada a atender muitos pacientes no curto período de tempo, acho que vai perdendo esse cuidado. $O$ isolamento absoluto leva muito tempo para fazer. A gente acaba perdendo esse costume apesar de ser bem melhor que uma restauração seja feita sem isolamento absoluto.

(AOdo 01)

De forma reincidente fica, então, a evidência da priorização do ensino técnico, tanto quanto a existência de fragmentação entre teoria e prática, entre ensino universitário e contexto real de atuação. Estas características podem estar relacionadas à postura desumanizada em termos freireanos ${ }^{35,36,79-88}$.

\subsubsection{Segunda Categoria: O professor no ensino de Odontologia}

Foram relatados pensamentos que remontam ao modelo da educação bancária no ensino de Odontologia. Na perspectiva dos entrevistados, há certa ausência do professor no processo ensino-aprendizagem, legando ao aluno a tarefa de estudar por si mesmo principalmente em relação às questões que não ficaram muito esclarecidas 
no contato com o docente. Por isso, é referido que o curso não ensina tudo o que é necessário para o desenvolvimento pleno da habilidade requerida do odontólogo.

Tem muitos professores que deixam a desejar, que a gente se pergunta o que estão fazendo na faculdade. Mas acho que em todos os setores da educação existem aqueles professores que não tem capacidade. Acho que a relação professor-aluno tem que ser também humana, tem que haver respeito mútuo e que eles passam procuram transmitir sempre o conhecimento e as experiências deles para gente.

(AOdo 02)

A gente não pode ficar esperando muito do professor. A gente vê muito professor que deixa a desejar. Ai você tem que pesquisar, estudar, ler livro, ler o conteúdo que esta sendo ministrado.

(AOdo 01)

$\mathrm{Na}$ faculdade pública a gente aprende muito a estudar sozinha. Tem que ter iniciativa de ir na biblioteca pegar o livro e estudar. Não pode ficar esperando pelo professor.

(AOdo 01)

O curso não ensina tudo, mas ensina uma boa parte. A grande maioria é nossa obrigação ser auto-didata. Não é por que alguma coisa não foi passado na faculdade que também não vou me interessar, não vou buscar aprender. Tem que buscar. Não só esperar pelo conhecimento que a faculdade passa.

(AOdo 02)

Algumas características mencionadas pelos entrevistados são paradoxais a estas apresentadas anteriormente. Alguns de seus professores mantinham uma postura de concorrência, lidando com o aluno como um futuro concorrente em potencial, o que, na percepção dos entrevistados, é um comportamento prejudicial ao ensino, na medida em que estes docentes não trabalham os conteúdos na totalidade, prejudicando a aprendizagem dos procedimentos e técnicas odontológicas durante o curso. 
Acho que aqui nós temos bons professores, apesar de que alguns deles vêem o aluno como um futuro concorrente profissional, mas eu acho que fora isso nós tivemos bons professores, capaz de nos ensinar.

(AOdo 03)

Muitos o professores, nem todos, enxergam a gente como possível como um competidor que futuramente irá estar competindo com ele.

(AOdo 02)

A participação de alguns professores do curso de Odontologia, no processo ensino-aprendizado, foi considerada fundamental pelos entrevistados, na medida em que o ensino odontológico é, em grande medida, regido pelo desenvolvimento de habilidades clínicas, dada a característica operativa da profissão, que prima pela habilidade manual em especial. Neste contexto, os professores cumpriam sua função auxiliando o aluno neste processo, além de haver características como o lidar com o aluno como um ser humano, preocupação no ensino que, no caso da Odontologia, pauta-se na prática clínica odontológica, não apenas as técnicas, mas também o porquê de cada uma delas.

É importante a participação do professor, ainda mais que na Odontologia a gente aprende as coisas na prática. É importante a gente ter um professor do lado para estar orientando, para ver todos os passos e procedimentos.

(AOdo 01)

Os professores passam todas as técnicas dos procedimentos, passam todo o conhecimento nas aulas teóricas, não só o procedimento em si mas também mostrando o porquê que a gente esta fazendo isso, porque quando se usa um material o que acontece, qual é o efeito que tem no dente, na estrutura dele. Eles se sentam com a gente, se a gente não está conseguindo fazer, sentam, fazem e explicam como é direitinho.

(AOdo 02) 
A postura verticalizada do professor, com claro monopólio do conhecimento e o preconizar do ensino técnico em detrimento da formação humana, são características da educação bancária ${ }^{35,36,79-88}$, que emergiram no atual estudo.

\subsubsection{Terceira Categoria: A humanização no modelo pedagógico}

Dentre as disciplinas ministradas no curso, segundo os entrevistados, Odontologia Social foi considerada a disciplina que mais apresentou uma compreensão complexa do paciente, construindo conhecimentos sobre ética na conduta clinica, trabalhando indistintamente o bom tratamento clínico independente de este ser realizado em consultório particular ou no serviço público de saúde. Para os entrevistados, a disciplina se pauta em uma visão totalizadora do paciente, que é entendido como um ser humano e não um objeto de trabalho tão somente.

A professora de Odontologia social sempre toca nessa tecla, de tratar o paciente como um todo, tratar com respeito, com ética, tratar o paciente como uma pessoa não como um objeto.

(AOdo 01)

Desde o inicio que a gente ingressou na faculdade na Disciplina de Odontologia e saúde coletiva trabalharam bastante esta questão a respeito da saúde publica, da saúde na comunidade. Sempre procurando esclarecer e colocar na nossa cabeça que a gente tem que enxergar o paciente como um todo, não como um objeto que você vai estar trabalhando em cima dele mas você tem que fazer por merecer a confiança daquele paciente, que está sentado ali, que você nem percebe mas que ele está com medo, receoso, que tem esperança que você possa resolver o problema dele naquela determinada situação. Que a gente deve trabalhar da melhor forma possível, independente de estar em um consultório particular ou estar lidando em massa. Que a gente deveria agir e não desanimar 
com as condições, procurar fazer sempre o melhor apesar das adversidades do serviço público.

(AOdo 02)

Há certa polarização entre acadêmicos na importância da percepção da complexidade do paciente. Alguns entrevistados apresentam proximidade da visão crítico social, em que os determinantes de saúde estão implicados na prática clínica; havendo, na mesma medida, acadêmicos que percebem exclusivamente os aspectos biológicos envolvidos no desenvolvimento da doença no organismo que irão intervir como odontólogos.

Desde o primeiro contato profissional paciente interfere até no convívio do paciente. Você esta preparando aquele paciente para o convívio social e a gente vê que quando você consegue trazer o bem estar para aquele paciente, realização pessoal a vida dele, a gente percebe que melhora. As vezes ele chega na clínica triste ou então zangado, chateado, estressado e a medida que o tempo vai passando que você realizando os procedimentos ele vai vendo que ele está melhorando. Já vai mudando. Ele já vai se tornando uma pessoa mais receptiva, já vai te dar um bom dia, já vai andar com sorriso no rosto, já vai perguntar se você está bem. A gente interfere na humanização.

(AOdo 03)

Existem diferenças sociais entre as pessoas. Têm pacientes com nível econômico baixo, com nível econômico mediano e nível econômico com poder aquisitivo maior. Existe essa diferença mas para o atendimento odontológico não faz diferença de tratamento. Diferenças sócio econômicas existem sim mas diferenças no tratamento não. $O$ odontológico sempre procura atender o paciente com a mesma atenção, com a mesma dedicação, com a mesma qualidade seja de qualquer nível socioeconômico ele for.

(AOdo 02)

Com certeza para as crianças o que é importante é o papel que vai refletir no futuro delas. No paciente adulto com relação a estética dos paciente desdentado que vem fazer prótese porque estão com vergonha de sorrir no ambiente social que vivem. A gente prioriza 
restaurar aquele dente porque está afetando o convívio social dele. É nisso que a gente tem influência na pessoa.

(AOdo 01)

No curso de graduação, a imagem do odontólogo foi construída para estes acadêmicos, como um profissional que tem status em sociedade e que, por isso, deve manter postura em sociedade.

A gente está estudando orientação profissional de um dentista. Querendo ou não ele tem um certo espaço na sociedade então é bom que seja uma pessoa com uma boa reputação, que não fique arrumando escândalo por ai, que seja uma pessoa apresentável, que saiba falar, que saiba se comunicar, conversar com o paciente.

(AOdo 01)

A necessidade contribuição do modelo pedagógico à formação do odontólogo

crítico social $^{35,36,79-88}$ é premente, dadas as perspectivas levantadas pelo grupo, com foco no SUS.

\subsubsection{Quarta Categoria: A humanização na prática de Odontologia}

Segundo os entrevistados, a maioria dos odontólogos, na sua prática clínica, mantém uma postura distante do paciente, em certa medida hierarquizada e reducionista, se preocupando exclusivamente com as questões clínicas odontológicas e desconsiderando o entorno sócio-cultural do paciente, o que não é considerado correto segundo os acadêmicos de Odontologia. Deve ser ressaltado que todos os 
entrevistados pautaram sua colocação na experiência pessoal prévia a graduação, que reflete a vivência em consultório particular e não no serviço público de saúde.

A maioria dos odontólogos tinham uma postura bastante séria e fria. Não procuravam nem fazer uma anamnese, nem ter um conhecimento da pessoa, a respeito do que o paciente tem de queixa, qual são as suas aflições, o que está procurando no consultório. Outros têm uma relação melhor, mais humana, procura saber um pouco mais, conversar, deixar a vontade, tranqüilizar no consultório odontológico. Tive oportunidade de lidar com esses dois tipos de profissionais: profissionais receptivos e profissionais frios mais técnicos.

(AOdo 02)

Discordo da postura do profissional não procurar ter uma boa relação com o paciente, não dar abertura para falar o que esta sentido, o que pensa. Discordo também daqueles que não transmitem o conhecimento para o paciente, o que ele tem, o que pode fazer para melhorar o que tem e o que profissional vai fazer. Isso foi uma grande falha que eu percebi nos profissionais antes de ingressar na faculdade.

(AOdo 03)

Era uma relação estritamente profissional mesmo entendeu não tinha um contato pessoal não. Nunca ninguém me tratou com grosseria. $O$ atendimento normal, tratava bem, conversava, fazia anamnese as vezes até perguntava sobre a vida, se estava tudo bem, mas era uma coisa assim bem profissional mesmo.

(AOdo 01)

Eu era atendida de uma maneira bastante profissional: 'Boa tarde! Qual o seu nome? O que você tem?' E só olhavam a cavidade oral de um modo geral e não dizia o que eu tinha, porque iam fazer determinado procedimento. Nessa relação com o paciente eram distantes. A partir do momento que eu falei que eu estava fazendo Odontologia, ai começou haver uma relação melhor, explicando o por que das coisas.

(AOdo 02)

A percepção da inexistência de diferenças, enquanto seres humanos, entre o profissional e o paciente, é referida pelos entrevistados, apesar de existir diferença 
profissional em que o odontólogo, pelo seu conhecimento da área, presta serviços ao paciente.

Sou uma pessoa normal, tenho desejos, necessidades, assim como o paciente. A gente procura tratar todos os paciente, independente se tem recurso financeiro ou não, de estar bem vestido, se esta mal vestido, a gente sempre trata da mesma forma, não tem esta diferenciação não. É só a questão do conhecimento que me diferencia dele. Assim como ele deve ter o conhecimento dele, da profissão que ele exerce, eu tenho o meu conhecimento da minha profissão e a diferença é só técnica de conhecimento mesmo.

(AOdo 01)

Não existe diferença entre o paciente e o dentista. Os dois são cidadão, são seres humanos. O que o dentista tem a mais é o conhecimento técnico cientifico, que tem que saber conversar com o paciente da melhor forma possível para ele entender o procedimento que você vai fazer. Tem que deixar ele meio a parte do procedimento que você vai fazer nele, explicar sem termos difíceis, com termos teóricos fáceis.

(AOdo 03)

O conhecimento técnico é o que diferencia o paciente do dentista. Mas, por esta diferença, você chegar a discriminar o paciente quando o paciente não tem o mesmo entendimento que você acho que não existe. A gente aprende na faculdade a justamente não fazer uma diferença da gente e o paciente. A gente se impõem, mas não tem uma diferença pelo saber do paciente.

(AOdo 04)

Para alguns acadêmicos de Odontologia, a importância do atendimento humanizado repousa em se constituir como significativa estratégia de marketing na Odontologia, na medida em que o paciente que é bem atendido recomenda os serviços profissionais do odontólogo a outros pacientes.

Esta história de humanização é importante também, tanto que dizem que a propaganda 'boca a boca' é a melhor que tem. Se você é 
tratado bem em algum lugar, falam bem de ti para uma pessoa, mas se você for tratado mal falam para dez pessoas.

(AOdo 01)

Apesar do discurso pautado no mercado, como aludido anteriormente, em termos teóricos, estes acadêmicos idealizam a humanização e a proximidade do paciente como meta do odontólogo em sua prática clínica, condenando os que não se portam por esta postura. O que pode ser evidência de um discurso "politicamente correto", mas vazio, quando confrontado com a prática cotidiana, havendo incoerência, em termos freireanos ${ }^{35,36,79-88}$.

\subsubsection{Quinta Categoria: Desafios à humanização}

Ao se referirem as diferenças entre o atendimento odontológico no serviço público de saúde, em relação ao atendimento odontológico em consultório particular, emergiu, novamente, a perspectiva de que existe uma orientação da prática do odontólogo à prática, justificada não apenas pela existência de uma atenção ao paciente através do uso de materiais e recursos de melhores qualidades, mas principalmente pela menção de que, como o paciente no serviço particular está pagando pelo tratamento, este tratamento deve ser melhor do que no serviço público, sendo que consideram que o paciente não paga por estes serviços.

Nas falas dos entrevistados, a perspectiva da Odontologia mercantilista foi delimitada mais uma vez, sendo atividade profissional aludida como prestação de um serviço existente no mercado da saúde, como prática destinada ao consumidor que 
possa usufruir deste mercado. Em que o serviço público de saúde destina-se ao que não podem comprar o serviço do odontólogo.

Existe diferença sim, porque no consultório particular o dentista já tem aquela postura de fazer um serviço de ótima qualidade porque no final vai estar recebendo por isso então tem aquela postura de tratar o paciente não só visando ele como ser humano mas visando também o financeiro e costumam tratar melhor o paciente justamente por causa disso.

(AOdo 01)

Em ambiente fechado, um ambiente particular, o dentista sabe que se ele tratar bem mais pacientes virão do que de um público em que tá sendo mal remunerado. Para fazer esse trabalho tem que atender 20 pacientes por dia, 20 pacientes em uma manhã ou em uma tarde. Acredito que ele não faça com a mesma qualidade e dedicação se ele tivesse com mais tempo e dentro do consultório particular. Acredito que exista diferença embora eu acho que não deveria ter mas tem sim com certeza. Com o paciente ali no serviço publico o dentista não se preocupa com o geral, quer resolver a dor e as vezes nem procura saber o que o paciente. Tem só quer remover a causa da dor e atender de uma forma técnica e prática para passar para o seguinte. É diferente do jeito que ele atende o paciente de uma classe maior, que pode pagar pelo tratamento no consultório particular e que é muito diferente.

(AOdo 02)

O dentista está atendendo para educar e para fazer o trabalho que esta sendo pago pelo paciente. E pronto. É isso.

(AOdo 03)

Querendo ou não a Odontologia é um comércio. A pessoa está pagando pelo serviço.

(AOdo 03)

A visão reducionista, da implicação do ato odontológico em sociedade também foi demarcada, no aspecto das possibilidades que o odontólogo tem de atuação, referida pelo grupo apenas em suas dimensões clínicas e de cunho odontológico. 
É um dever social do dentista alertar. Por exemplo, o paciente pode ter mas hálitose. $O$ dentista tem que informar ao paciente porque 0 paciente não vai conseguir arrumar uma namorada, não vai ter um convívio social com outras pessoas. Tem que informar, tem que se tratar. Tem que informar o paciente para ele ter uma boa relação com a sociedade normal. Parece brincadeira mas isso muitas vezes afasta as pessoas.

(AOdo 04)

Tenho que olhar o paciente como um todo se o meu paciente chega no meu consultório com um câncer de pele eu vou ter que chegar e falar para ele alertar, não deixar de mão porque tem o dentista que vai só olha a boca mesmo e mal principalmente os mais antigos, agente tem que olhar o ser humano como um todo a saúde geral se preocupar com a saúde geral.

(AOdo 03)

A percepção do paciente que somente tem no serviço público de saúde a possibilidade de atendimento odontológico e a clara relação mercantil estabelecida entre os odontólogos e os pacientes em consultório particular, encaminham para o pensamento de que a formação do odontólogo esta na contramão da construção de profissional humanizado, segundo a perspectiva freireana ${ }^{35,36,79-88}$.

\subsubsection{Sexta Categoria: Ética, direitos e deveres do paciente}

Com relação aos aspectos da ética profissional, referiu-se a necessidade de diálogo aberto e claro entre o odontólogo e paciente, o qual deve ser informado sobre os procedimentos que serão realizados com os mesmos. A postura ética no tratamento também retrata uma conduta de sigilo e de não exclusão, segundo o que afirmam estes entrevistados. Outro ponto referido foi à questão dos limites profissionais, 
referindo-se a não invadir competências de outras profissões de saúde, tal como a Medicina.

Acho que tem que jogar limpo com o paciente, tem que informar porque o paciente não é objeto. Ele é humano, está ali escutando o que você fala. O paciente não é um objeto. É uma pessoa como você, humano, que está passando por um procedimento que até a gente pode estar com medo se fosse com a gente no lugar dele.

(AOdo 04)

Acho que o paciente tem que saber de tudo que a gente faz, todos os procedimentos que a gente esta fazendo. Quando a gente está fazendo endodontia sempre perguntam o que é, sobre a lima, por que tem que abrir o conduto. A gente explica tudo direitinho para ele.

(AOdo 01)

É também importante ter essa postura ética, não ficar comentando ou com outro profissional ou com outro paciente a respeito do que você atendeu. Você tem que não mudar a sua postura conforme você atende devido a um determinado aspecto daquele paciente, tipo o paciente com AIDS, o paciente que possui uma manifestação de uma doença sexualmente transmissível. O profissional tem o dever ético de não falar mas também não mudar a postura por causa disso. A partir do momento que o paciente senta na sua cadeira você é responsável por ele ali, não fazer nenhuma mutilação, nenhum procedimento que você sabe que não deve ser feito.

(AOdo 02)

A ética profissional que a gente tem que ter é a de não estar comentando certos casos com os outros profissionais, com outro paciente que esteja ali no consultório, o que acontece ali, o que aconteceu, não tem que sair comentando o que o paciente tem.

(AOdo 03)

A ética está quando você vai fazer um atestado. Tu tem que ver quais são os limites do que faz. Se deve dar atestado ou não como cirurgião dentista. A mesma coisa quando você faz uma prescrição de medicamento. Tem que seguir a profissão dentro do que é imposto para gente, do que cabe ao dentista, não intervir muito nessa área médica.

(AOdo 03)

Precisa de uma ética. A gente respeita o paciente, por exemplo o paciente soro positivo. Não vai sair daqui divulgando que o paciente tem isso. É uma questão de ética. Outra é conversar com o paciente 
sobre dinheiro, que tem materiais que o paciente arca com o custo. A gente tem que conversar com ética, cobrando o paciente mas respeitando.

(AOdo 04)

Reincide a temática da importância do mercado odontológico na conduta do odontólogo, sendo aludido que, na medida em que o paciente paga pelo atendimento odontológico tem direito de saber o que está acontecendo. Não mencionam se os pacientes do serviço público, que na concepção destes acadêmicos não pagam pelo serviço, também possuam o mesmo direito.

O paciente tem direito de saber o que vai acontecer na consulta. Ele está pagando, tem dinheiro e quer a consulta. Você tem que explicar, tem que ser bem claro, explicar o tratamento que você vai fazer, quanto custa, esclarecer da forma correta, se tem a possibilidade de dar errado explicar antes de realizar.

(AOdo 03)

Ressaltando a perspectiva mercadológica da prática do odontólogo na postura destes acadêmicos, futuros odontólogo, inclusive indicando que a ética é direito de quem paga pelos serviços particulares e, silencia sobre esta questão para quem apenas tem no SUS a possibilidade do atendimento, a que se refletir na formação dos odontólogos, buscando por caminhos que rompam com a formação nesta lógica e, efetivamente, construam perfil profissional pautado na atuação crítico reflexiva ${ }^{35,36,79-}$ 88, para então formar odontólogos que permeiem a ação como atores sociais em saúde, junto aos determinantes histórico-políticos e críticos-sociais frente a necessidade de promoção de saúde, principalmente no modelo do PSF. 


\subsubsection{Sétima Categoria: A prática Odontológica e saúde coletiva}

Com relação à prática odontológica em Saúde Coletiva, prevaleceu a ausência de debates, dentro das entrevistas dos acadêmicos de Odontologia, os quais apresentaram sua profissão com um talhe voltado a prática privada, reafirmando conceitos e posturas aludidas anteriormente no presente estudo.

Inclusive, quando se referem à prática do odontólogo em Saúde Coletiva, aludem as atividades clínicas semelhantes ao consultório particular, com a diferença de que no serviço publico há deficiência em infra-estrutura e materiais odontológicos, acrescido das atividades educativas, que se resumem a palestra em comunidade.

Não foi mencionada nos discursos sobre saúde coletiva a questão da complexidade do entorno sócio-cultural dos pacientes, aludida em outros momentos das entrevistas, aparentando desarticulação deste conhecimento teórico com a prática odontológica na percepção destes acadêmicos.

O serviço em saúde coletiva é entendido como prática destinada a comunidades isoladas e populações carentes, e não como uma ação intersetorial e que envolve e é destinada todos os estratos sociais, conforme preconizam os princípios do SUS.

Outro detalhe é o enfoque do odontólogo na doença, principalmente na cárie, e não nas demais afecções orais e, menos ainda, no enfoque preventivo e de promoção de saúde. Também registraram a idéia da prática em Saúde Coletiva como filantropia e que o odontológo que a ela se dedica apresenta vocação humanitária. 
Como nosso trabalho é prático, a gente tem atendimento curativo que a gente chama de 'fazer restauração, fazer exodontia'. Também tem o papel preventivo, de sair nas comunidades, de dar palestras. É falar da importância da saúde bucal, é ensinar técnicas de escovação, ir em uma escola carente, pegar as crianças, ensinar escovação, usar o fio dental, é ensinar porque que tem que escovar, ensinar o que é gengivite, o que é cárie, explicar como é que dá todo esse processo de doença.

(AOdo 01)

Na Saúde coletiva a gente teve no primeiro período e falava a questão do SUS, a questão da gente trabalhar nas escolas. Infelizmente quando a gente estava em Odontologia social a gente não pode ir nas escolas porque estavam usando um calendário especial e as escolas estavam em férias.

(AOdo 03)

Tem umas pessoas que têm mais é esse perfil, de sair ir para as comunidades. Tem outras que não, que não gostam e preferem atuar no consultório particular, atender pessoas de classe mais altas. Que vai para Saúde Coletiva geralmente são pessoas mais comunicativas, que se interessam pelos problemas das pessoas, pessoas que realmente enxergam a importância da saúde bucal, que querem passar isso para as pessoas, que querem atuar nessa área preventiva.

(AOdo 05)

Eu gosto de lidar com o público. Gosto mais de lidar com o paciente que tenha muita coisa para fazer, de um nível ate economicamente mais baixa do que uma classe mais alta. Gosto do contato pacienteprofissional e do que você pode fazer para modificar o que você esta vendo e lidar com a parte preventiva, passar conhecimento, agir como educador com aquele paciente e também buscar adequar as condições da parte curativa para estes pacientes. Nesses pacientes, na saúde coletiva a gente se realiza de uma maneira maior, você consegue atingir os seus objetivos, você vê no final que o seu paciente adquiriu consciência, que ele tem que ter uma saúde bucal para não prejudicar essa saúde geral, que a saúde bucal e a saúde geral estão interligadas. Só de você ver que ele adquiriu conhecimento, que ele tem interesse em melhorar em escovar e procura o dentista também de tempos em tempos, de 6 em 6 meses para fazer o exame preventivo, só de você ver que o paciente adquiriu aquela consciência, você tem uma realização profissional maior.

(AOdo 02)

Seguem-se as sínteses dos produtos do grupo focal e das entrevistas individuais com discentes do curso de Odontologia. 
Quadro 15: Síntese das perspectivas apresentadas por acadêmicos do último período do curso de Odontologia sobre o modelo pedagógico do curso

\begin{tabular}{|c|c|c|}
\hline Produto do Grupo Focal & Informações das entrevistas semi-estuturadas & Convergências \\
\hline $\begin{array}{l}\text { Núcleo Temático 1: O modelo } \\
\text { pedagógico } \\
\text { - Professor: principal } \\
\text { modulador da relação com o } \\
\text { aluno } \\
\text { - Professores autoritários e } \\
\text { verticalizados: né náo } \\
\text { permitem diálogo nem } \\
\text { mesmo quando estão } \\
\text { errados es alunos corretos } \\
\text { - Professores próximos e } \\
\text { abertos: influencia positiva } \\
\text { para os futuros odontólogos } \\
\text { - Relação distante entre } \\
\text { professor e aluno: } \\
\text { referência para a relação } \\
\text { odontólogo-paciente } \\
\text { - Professores que não estão } \\
\text { preocupados em ensinar } \\
\text { seus alunos nan ensinam } \\
\text { Professores não ens } \\
\text { por alunos serem seus } \\
\text { futuros concorrentes. } \\
\text { - Diversas disciplinas para } \\
\text { entendimento do ser } \\
\text { humano a }\end{array}$ & 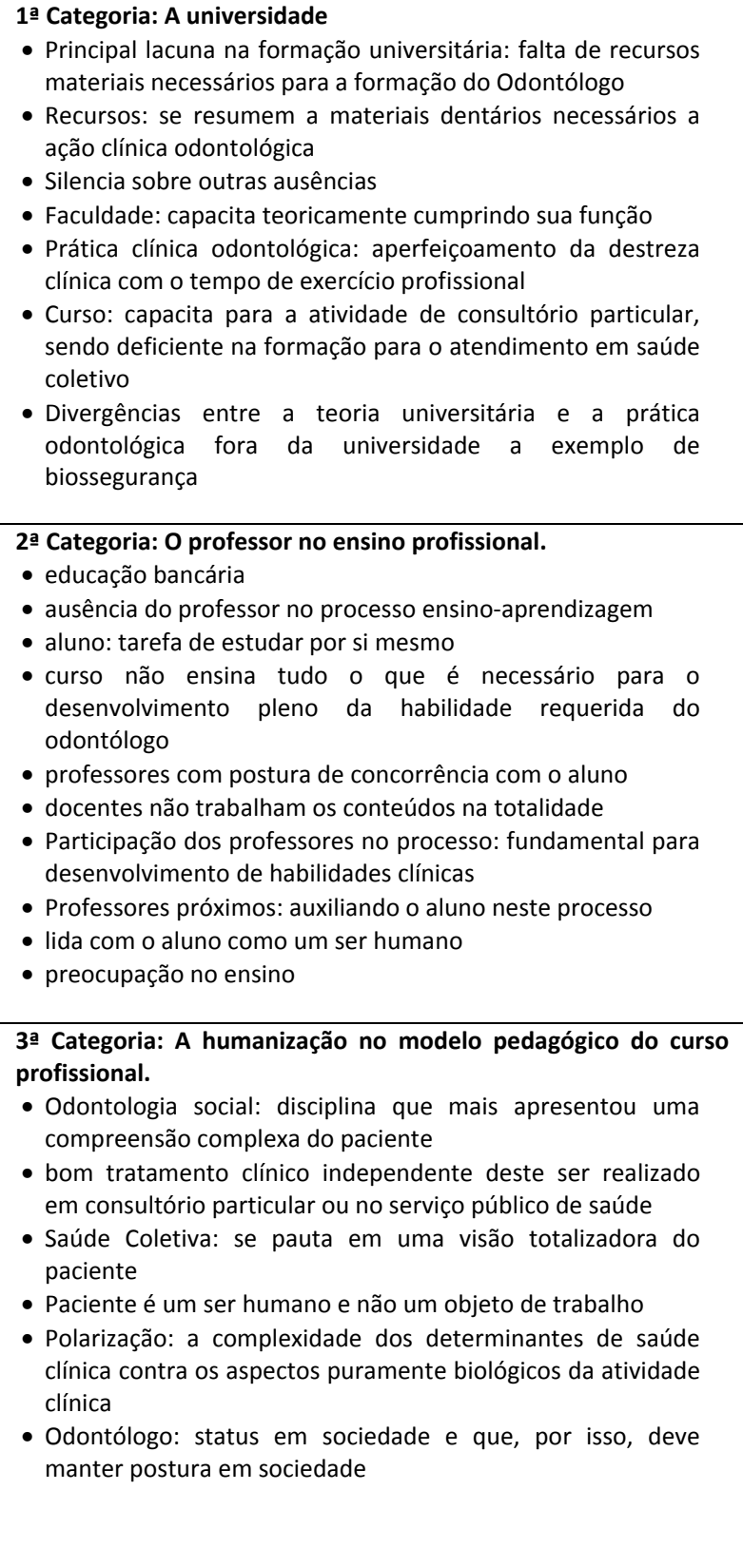 & $\begin{array}{l}\text { O curso apresenta } \\
\text { centralidade na formação } \\
\text { teórica e na vivência de } \\
\text { algumas práticas para } \\
\text { desenvolver as habilidades } \\
\text { técnicas iniciais. No entanto o } \\
\text { tempo de formação do } \\
\text { odontólogo fará com que o } \\
\text { mesmo se aprimore em } \\
\text { termos do exercício } \\
\text { profissional. No curso de } \\
\text { Odontologia existem } \\
\text { características da educação } \\
\text { bancária, como professores } \\
\text { distantes a necessidade dos } \\
\text { alunos não terem o apoio de } \\
\text { muitos docentes para seu } \\
\text { desenvolvimento, existindo } \\
\text { docentes que não tem uma } \\
\text { postura competitiva com o } \\
\text { discente, o qual é percebido } \\
\text { como futuro concorrente de } \\
\text { mercado. Alguns docentes } \\
\text { apresentam uma postura } \\
\text { progressista e horizontal com } \\
\text { o aluno. A distância do } \\
\text { professor do aluno reflete-se } \\
\text { na postura distante que o } \\
\text { futuro odontólogo apresente } \\
\text { em relação ao paciente. } \\
\text { Apesar de haver debate } \\
\text { sobre a complexidade dos } \\
\text { determinantes de saúde, os } \\
\text { odontólogos apresentam } \\
\text { dificuldades do } \\
\text { operacionalização } \\
\text { conceitos junto a sua prática } \\
\text { clínica. }\end{array}$ \\
\hline
\end{tabular}


Quadro 16: Síntese das perspectivas apresentadas por acadêmicos do último período do curso de Odontologia sobre o odontólogo

\begin{tabular}{|c|c|c|}
\hline Produto do Grupo Focal & Informações nas entrevistas semi-estuturadas & Convergências \\
\hline 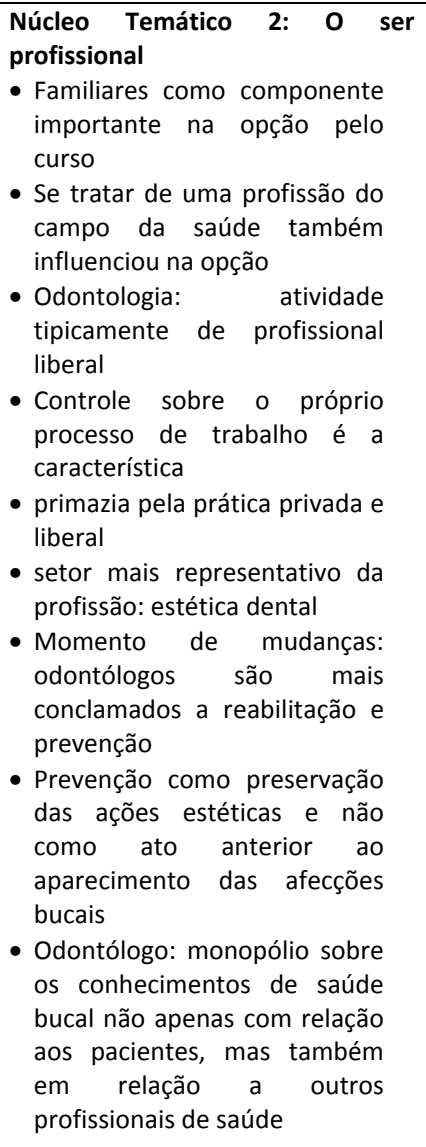 & $\begin{array}{l}\text { 4a Categoria: A humanização na prática do profissional. } \\
\text { - odontólogos na prática clínica: postura distante do paciente } \\
\text { - odontólogos: hierarquizados e reducionistas } \\
\text { - preocupação clínica nos aspectos odontológicos } \\
\text { - odontólogos desconsideram o entorno sócio-cultural do } \\
\text { paciente } \\
\text { - inexistência de diferenças enquanto seres humanos entre o } \\
\text { profissional e o paciente } \\
\text { - odontólogo é um prestador de serviços ao paciente. } \\
\text { - importância do atendimento humanizado: estratégia de } \\
\text { marketing na Odontologia } \\
\text { - paciente que é bem atendido recomenda os serviços } \\
\text { profissionais do odontólogo a outros pacientes }\end{array}$ & $\begin{array}{l}\text { A Odontologia é percebida } \\
\text { como uma profissão } \\
\text { tipicamente liberal em que } \\
\text { existe status social. A prática } \\
\text { principal é direcionada ao } \\
\text { mercado, de forma que a } \\
\text { Odontologia sempre enfocou } \\
\text { o consultório particular como } \\
\text { o modelo da prática } \\
\text { profissional. O odontólogo é } \\
\text { um prestador de serviços e a } \\
\text { humanização é uma } \\
\text { estratégia de marketing. } \\
\text { Presta serviço a quem pode } \\
\text { pagar por ele. }\end{array}$ \\
\hline
\end{tabular}


Quadro 17: Síntese das perspectivas apresentadas por acadêmicos do último período do curso de Odontologia sobre aspectos do trabalho do odontólogo e seu relacionamento com o paciente

\begin{tabular}{|c|c|c|}
\hline Produto do Grupo Focal & $\begin{array}{c}\text { Informações das entrevistas semi- } \\
\text { estuturadas }\end{array}$ & Convergências \\
\hline 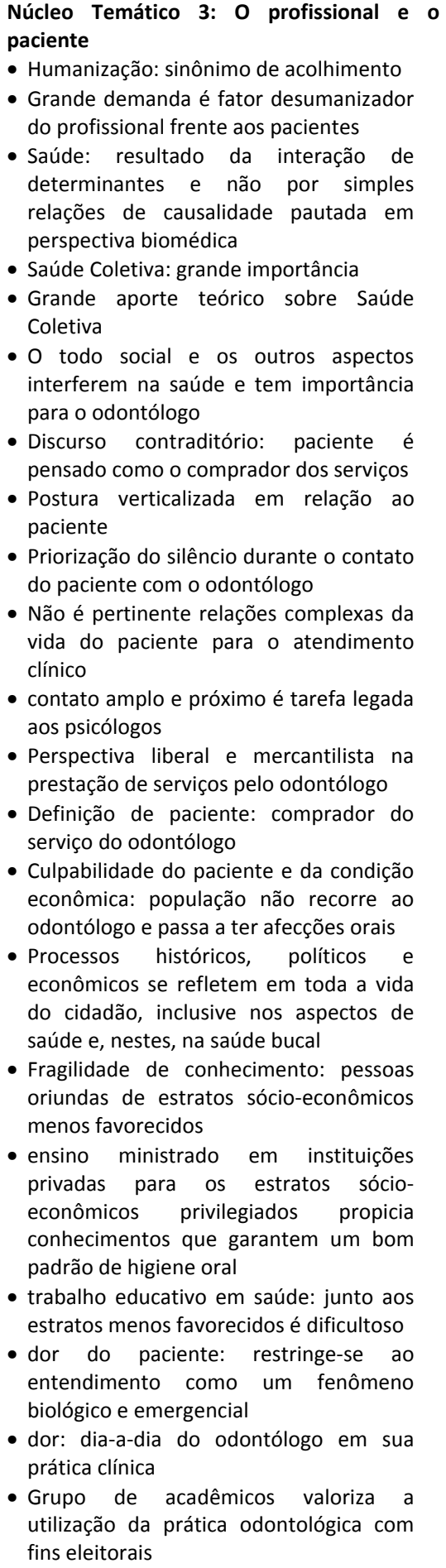 & 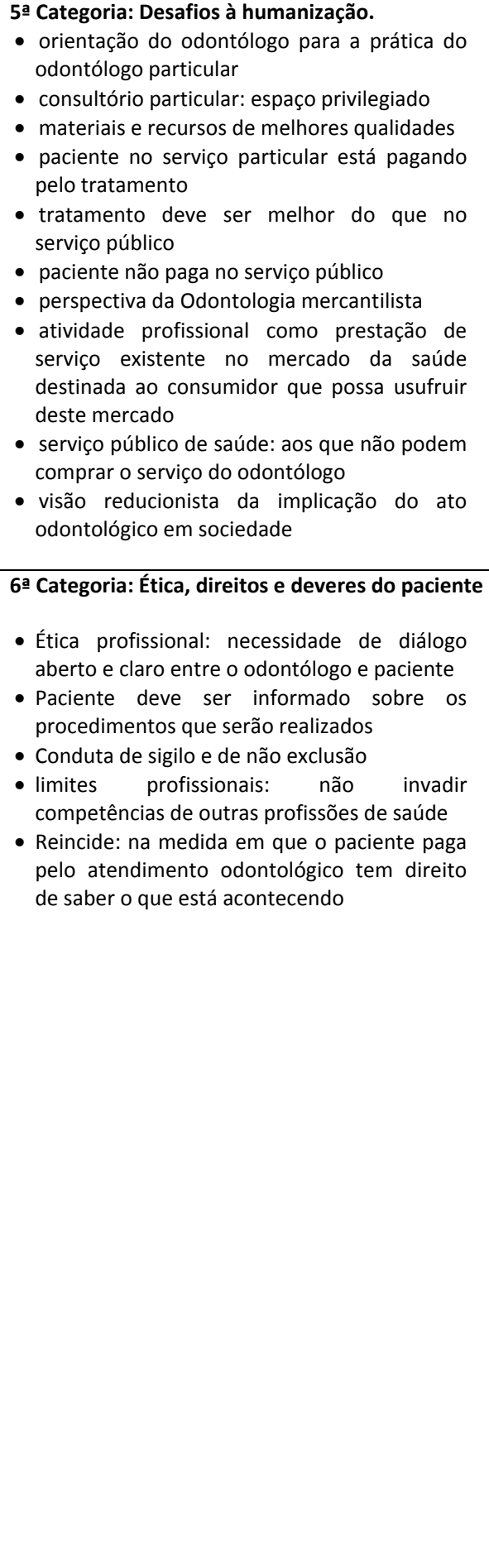 & $\begin{array}{l}\text { Apesar do discurso de que a } \\
\text { saúde é determinada por } \\
\text { múltiplos fatores muitas vezes } \\
\text { não relacionados aos aspectos } \\
\text { clínicos, o odontólogo tem seu } \\
\text { direcionamento para a pratica em } \\
\text { consultório privado em que o } \\
\text { paciente é um comprador de } \\
\text { serviços. o paciente deve } \\
\text { procurar o odontólogo, que } \\
\text { detém o monopólio do } \\
\text { conhecimento odontológico. } \\
\text { Caso não o procure há } \\
\text { culpabilidade do paciente no } \\
\text { processo de desenvolvimento da } \\
\text { doença oral. O serviço público } \\
\text { destina-se aos pacientes que não } \\
\text { podem pagar pelo atendimento } \\
\text { particular. Grandes demandas de } \\
\text { atendimento desumanizam. }\end{array}$ \\
\hline
\end{tabular}


Quadro 18: Síntese das perspectivas apresentadas por acadêmicos do último período do curso de Odontologia sobre aspectos do trabalho do odontólogo nos serviços de saúde

\begin{tabular}{|c|c|c|}
\hline Produto do Grupo Focal & Informações entrevistas semi-estuturadas & Convergências \\
\hline $\begin{array}{l}\text { Núcleo Temático 4: O profissional e o } \\
\text { trabalho em saúde } \\
\text { - o profissional não pode se limitar a } \\
\text { priorização das especialidades } \\
\text { - indivíduo: deve ser encarado de } \\
\text { maneira sistêmica, em que cada parte } \\
\text { se articula com o todo } \\
\text { - Equipes multiprofissionais: } \\
\text { espaços privilegiados de saúde } \\
\text { - Saúde da Família: principal estratégia } \\
\text { neste sentido } \\
\text { - Saúde pública: envolvimento de todos } \\
\text { os profissionais da equipe de saúde, da } \\
\text { comunidade e até mesmo os } \\
\text { indivíduos } \\
\text { - Relações pessoais tem participação no } \\
\text { processo de saúde da comunidade }\end{array}$ & $\begin{array}{l}\text { 7a Categoria: A prática profissional e saúde coletiva } \\
\text { - ausência de debates dentro das entrevistas dos } \\
\text { acadêmicos de Odontologia } \\
\text { - profissão com um talhe voltado a prática privada } \\
\text { - prática do odontólogo em saúde coletiva: } \\
\text { atividades semelhantes ao consultório particular } \\
\text { - diferença: no serviço publico há deficiência em } \\
\text { infra-estrutura e materiais odontológicos, } \\
\text { acrescido das atividades educativas } \\
\text { - atividades educativas: resume-se a palestra em } \\
\text { comunidade } \\
\text { - Não foi mencionado nos discursos sobre saúde } \\
\text { coletiva a questão da complexidade do entorno } \\
\text { sócio-cultural dos pacientes } \\
\text { - desarticulação deste conhecimento teórico com a } \\
\text { prática odontológica } \\
\text { - Serviço em saúde coletiva: destinada a } \\
\text { comunidades isoladas e populações carentes e } \\
\text { não como uma ação intersetorial e que envolve } \\
\text { todos os estratos sociais } \\
\text { - enfoque na doença, principalmente na cárie, e } \\
\text { não nas demais afeçõos orais } \\
\text { - saúde coletiva como filantropia } \\
\text { - odontológo que a ela se dedica: vocação } \\
\text { humanitária }\end{array}$ & $\begin{array}{l}\text { Apesar do discurso sobre a } \\
\text { implicação do entorno social do } \\
\text { paciente na saúde e da } \\
\text { importância deste enfoque tanto } \\
\text { para a Saúde Pública como para o } \\
\text { trabalho em equipe, o que foi } \\
\text { levantado pelo produto do grupo, } \\
\text { quando nos discursos individuais, } \\
\text { revela-se que o odontólogo não } \\
\text { possui um modelo compatível } \\
\text { como uma prática coletiva que se } \\
\text { paute em operacionalizar estes } \\
\text { conceitos e a prática } \\
\text { odontológica em saúde pública } \\
\text { não foge do modelo de } \\
\text { consultório particular mas que, } \\
\text { por ser público, tem problemas } \\
\text { com recursos, até por que é } \\
\text { destinada a quem não pode } \\
\text { pagar pelo serviço particular. }\end{array}$ \\
\hline
\end{tabular}




\subsection{A análise documental}

Antes de iniciar a descrição da composição dos currículos dos cursos estudados, é importante definir duas modalidades de disciplinas, quanto a obrigatoriedade do graduando em cursá-las:

(a) Disciplina obrigatória é aquela em que, para se graduar, obrigatoriamente o discente deverá ser aprovado;

(b) Disciplina optativa, refere-se a disciplinas que são oferecidas pelos cursos como complementação do conhecimento legado pelas disciplinas obrigatórias mas que o discente opta se quer cursá-las, quais e quando cursá-las.

\subsubsection{As disciplinas do curso de Enfermagem}

Com relação ao curso de Enfermagem as disciplinas que o compõe dispuseramse conforme as tabelas a seguir.

Tabela 2 - categorização das disciplinas do curso de Enfermagem, conforme o enfoque

\begin{tabular}{|c|c|c|c|c|c|}
\hline $\begin{array}{c}\text { Categoria da } \\
\text { disciplina }\end{array}$ & $\begin{array}{c}\text { Quantidade de } \\
\text { Disciplinas }\end{array}$ & Períodos & $\begin{array}{l}\text { Créditos } \\
\text { teóricos }\end{array}$ & $\begin{array}{l}\text { Créditos } \\
\text { práticos }\end{array}$ & $\begin{array}{l}\text { Total de } \\
\text { créditos }\end{array}$ \\
\hline Básicas & 13 disciplinas & $10,2 ㅇ$ e $3 ㅇ$ & 45 & 6 & 51 \\
\hline Humanidades & 6 disciplinas & 10 e 2 은 & 14 & 0 & 14 \\
\hline Interface & 5 disciplinas & $\begin{array}{l}\text { Optativa, } \\
\text { 10 e 6ㅇ }\end{array}$ & 13 & 0 & 13 \\
\hline Saúde Pública & 5 disciplinas & $\begin{array}{c}\text { Optativa, } \\
\text { 4o e 6o }\end{array}$ & 11 & 5 & 17 \\
\hline Profissionalizantes & 20 disciplinas & $\begin{array}{l}\text { Optativa, } \\
\text { 3ㅇ ao 80 }\end{array}$ & 36 & 54 & 90 \\
\hline TOTAIS & & & 119 & 64 & 183 \\
\hline
\end{tabular}


Tabela 3 - Disciplinas humanizadoras, na matriz curricular do curso de Enfermagem

\begin{tabular}{ccc}
\hline Disciplina & Períodos & $\begin{array}{c}\text { Total de } \\
\text { créditos }\end{array}$ \\
\hline Bioética & optativa & $2(2: 0)$ \\
Relações interpessoais & optativa & $2(2: 0)$ \\
Psicologia Geral & 10 & $4(4: 0)$ \\
Antropologia Filosófica & 20 & $2(2: 0)$ \\
Psicologia da Educação & 20 & $4(4: 0)$ \\
Sociologia & 20 & $4(4: 0)$ \\
TOTAL DE CRÉDITOS & & $14(14: 0)$ \\
\hline
\end{tabular}

Tabela 4 - Disciplinas de interface, na matriz curricular do curso de Enfermagem

\begin{tabular}{ccc}
\hline Disciplina & Períodos & $\begin{array}{c}\text { Total de } \\
\text { créditos }\end{array}$ \\
\hline Saúde e Sociedade & optativa & $4(4: 0)$ \\
Didática aplicada à Saúde & 10 & $2(2: 0)$ \\
História da Enfermagem & 10 & $2(2: 0)$ \\
Ética e Legislação de Enfermagem & 10 & $2(2: 0)$ \\
Educação em Saúde & 60 & $2(1: 1)$ \\
TOTAL DE CRÉDITOS & & $13(13: 1)$ \\
\hline
\end{tabular}

Tabela 5 - Disciplinas de Saúde Pública, na matriz curricular do curso de Enfermagem

\begin{tabular}{ccc}
\hline Disciplina & Períodos & $\begin{array}{c}\text { Total de } \\
\text { créditos }\end{array}$ \\
\hline Enfermagem em Atenção à Saúde da Família & optativa & $2(2: 0)$ \\
Epidemiologia & 40 & $3(2: 1)$ \\
Enfermagem em Saúde Coletiva & 60 & $8(4.4)$ \\
Saúde das populações indígenas & 60 & $2(2: 0)$ \\
Saúde e ambiente & 60 & $2(1: 1)$ \\
TOTAL DE CRÉDITOS & & $17(11: 5)$ \\
\hline
\end{tabular}

Os dados referentes a quantidade geral de créditos em cada uma das categorias da matriz curricular do curso de Enfermagem, no modelo pedagógico aplicado aos entrevistados, demonstram que cerca de $38 \%$ dos créditos cursados se 
referiam a disciplinas de conteúdo básico, 8\% a disciplinas da àrea de humanidades, 9\% disciplinas na interface entre humanidades e saúde, 9\% em Saúde Pública e 49\% de disciplinas referentes a profissionalização dos acadêmicos enquanto enfermeiros.

Com relação aos créditos teóricos, cerca de 37\% das disciplinas são da categoria das básicas, $12 \%$ das humanidades, $11 \%$ das disciplinas de interface, $9 \%$ das de Saúde Pública e $30 \%$ das disciplinas profissionalizantes. Os créditos práticos são distribuídos em $8 \%$ dos créditos para disciplinas de área básica, 7\% de Saúde Pública e 85\% profissionalizantes, não havendo articulação prática nas disciplinas da área de humanidades, assim como nas disciplinas de interface.

\subsubsection{As disciplinas do curso de Medicina}

Com relação ao curso de Medicina as disciplinas que o compõe dispuseram-se conforme as tabelas a seguir.

Tabela 6 - Categorização das disciplinas do curso de Medicina, conforme o enfoque

\begin{tabular}{|c|c|c|c|c|c|}
\hline $\begin{array}{c}\text { Categoria da } \\
\text { disciplina }\end{array}$ & $\begin{array}{c}\text { Quantidade de } \\
\text { Disciplinas }\end{array}$ & Períodos & $\begin{array}{l}\text { Créditos } \\
\text { teóricos }\end{array}$ & $\begin{array}{l}\text { Créditos } \\
\text { práticos }\end{array}$ & $\begin{array}{l}\text { Total de } \\
\text { créditos }\end{array}$ \\
\hline Básicas & 19 disciplinas & $\begin{array}{l}\text { Optativa, 1으 } \\
\text { ao 4은 }\end{array}$ & 87 & 10 & 97 \\
\hline Humanidades & 3 disciplinas & Optativa, 10 & 6 & 0 & 6 \\
\hline Interface & 5 disciplinas & Optativa, 5음 & 19 & 8 & 27 \\
\hline Saúde Pública & 5 disciplinas & $\begin{array}{l}\text { Optativa, } \\
4 \text {, 10ㅇ e } \\
11\end{array}$ & 10 & 23 & 33 \\
\hline Profissionalizantes & 27 disciplinas & $\begin{array}{l}\text { Optativa, } 40 \\
\text { ao } 11 \underline{0}\end{array}$ & 65 & 108 & 173 \\
\hline TOTAIS & & & 187 & 149 & 336 \\
\hline
\end{tabular}


Tabela 7 - Disciplinas humanizadoras na matriz curricular do curso de Medicina

\begin{tabular}{|c|c|c|}
\hline Disciplina & Períodos & Créditos \\
\hline Estudo de problemas brasileiros I & optativa & $1(1: 0)$ \\
\hline Estudo de problemas brasileiros II & optativa & $1(1: 0)$ \\
\hline Psicologia Geral & 10 & $4(1: 0)$ \\
\hline TOTAL DE CRÉDITOS & & $6(1: 0)$ \\
\hline
\end{tabular}

Tabela 8 - Disciplinas de interface na matriz curricular do curso de Medicina

\begin{tabular}{ccc}
\hline Disciplina & Períodos & créditos \\
\hline História da Medicina & optativa & $5(5: 0)$ \\
Psicanálise na cultura & optativa & $3(2: 1)$ \\
Psicopatologia & optativa & $3(2: 1)$ \\
Iniciação ao exame clínico & 50 & $9(6: 3)$ \\
Psicologia médica & 50 & $4(2: 2)$ \\
Medicina legal e deontologia & $6-$ & $3(2: 1)$ \\
TOTAL DE CRÉDITOS & & 27 \\
\hline
\end{tabular}

Tabela 9 - Disciplinas de Saúde Pública na matriz curricular do curso de Medicina

\begin{tabular}{ccc}
\hline Disciplina & Períodos & créditos \\
\hline Higiene social & optativa & $2(2: 0)$ \\
Epidemiologia I & $4-$ & $3(2: 1)$ \\
Epidemiologia II & $10 \%$ & $4(4: 0)$ \\
Saúde Coletiva & $10 \%$ & $4(2: 2)$ \\
Estágio em Medicina Preventiva & 110 & $20(0: 20)$ \\
TOTAL DE CRÉDITOS & & $33(10: 23)$ \\
\hline
\end{tabular}

As disciplinas da matriz do curso de Medicina se distribuíram quanto a quantidade de créditos em cerca de $29 \%$ de básicas, $2 \%$ da área de humanidades, $7 \%$ de interface, $10 \%$ de Saúde Pública e 52\% de profissionalizantes.

Descritivamente os créditos teóricos se distribuem em $46 \%$ para disciplinas básicas, $3 \%$ entre as de humanidades, $10 \%$ para as de interface; $5 \%$ para as de Saúde Pública e $34 \%$ para as profissionalizantes. Com relação aos créditos práticos, estes se 
distribuem em $6 \%$ para as disciplinas básicas, $5 \%$ para as disciplinas de interface, $15 \%$ em Saúde Pública e 72\% para disciplinas profissionalizantes. Não há créditos práticos nas disciplinas de humanidades.

\subsubsection{As disciplinas do curso de Odontologia}

Com relação ao curso de Odontologia as disciplinas que o compõe dispuseramse conforme as tabelas a seguir.

Tabela 10 - Categorização das disciplinas do curso de Odontologia, conforme o enfoque

\begin{tabular}{|c|c|c|c|c|c|}
\hline $\begin{array}{c}\text { Categoria da } \\
\text { disciplina }\end{array}$ & $\begin{array}{c}\text { Quantidade de } \\
\text { Disciplinas }\end{array}$ & Períodos & $\begin{array}{l}\text { Créditos } \\
\text { teóricos }\end{array}$ & $\begin{array}{l}\text { Créditos } \\
\text { práticos }\end{array}$ & $\begin{array}{l}\text { Total de } \\
\text { créditos }\end{array}$ \\
\hline Básicas & 18 disciplinas & 10 a 3은 & 44 & 20 & 64 \\
\hline Humanidades & Nenhum disciplina & - & 0 & 0 & 0 \\
\hline Interface & 2 disciplinas & $\begin{array}{c}\text { Optativa e } \\
40\end{array}$ & 6 & 0 & 6 \\
\hline Saúde Pública & 3 disciplinas & $\begin{array}{c}\text { Optativa, } 10 \\
\text { e } 6 \underline{0}\end{array}$ & 7 & 2 & 9 \\
\hline Profissionalizantes & 33 disciplinas & $\begin{array}{c}\text { Optativa, } 40 \\
\text { ao } 9 \underline{0}\end{array}$ & 54 & 98 & 152 \\
\hline TOTAIS & & & 111 & 120 & 231 \\
\hline
\end{tabular}

Tabela 11 - Disciplinas de interface na matriz curricular do curso de Odontologia

\begin{tabular}{ccc}
\hline Disciplina & Períodos & Créditos \\
\hline Ética profissional em Odontologia & Optativa & $3(3: 0)$ \\
Psicologia aplicada a Odontologia & $4 \underline{3}$ & $3: 0)$ \\
TOTAL DE CRÉDITOS & & $6(6: 0)$ \\
\hline
\end{tabular}

Tabela 12 - Disciplinas de Saúde Pública na matriz curricular do curso de Odontologia

\begin{tabular}{ccc}
\hline Disciplina & Períodos & $\begin{array}{c}\text { Total de } \\
\text { créditos }\end{array}$ \\
\hline Odontologia social II & Optativa & $3(1: 2)$ \\
Odontologia em saúde coletiva & 10 & $3(3: 0)$ \\
Odontologia social & 60 & $3(3: 0)$ \\
TOTAL DE CRÉDITOS & & $9(7: 2)$ \\
\hline
\end{tabular}


No curso de Odontologia, o total de créditos se distribui em $28 \%$ dos créditos em disciplinas básicas, 3\% em disciplinas de interface, 4\% em Saúde Pública e 65\% em disciplinas profissionalizantes. O curso não apresenta qualquer disciplina oriunda das humanidades.

Com relação aos créditos teóricos, estes se distribuem em $40 \%$ para disciplinas básicas, $5 \%$ para as de interface, $6 \%$ para as de Saúde Pública e $49 \%$ para as profissionalizantes. Dos créditos teóricos $16 \%$ são de disciplinas básicas, $2 \%$ de Saúde Pública e $82 \%$ profissionalizantes, inexistindo créditos práticos para as disciplinas de interface. 


\section{Capítulo 6}

\section{A EMERSÃO E O DIÁLOGO \\ Dialogando com o produto oriundo da ida ao Universo Empírico}

A realidade é complexa. Como ator imerso na realidade, o ser humano traz em si a complexidade. Sua vida é uma manifestação complexa.

Neste sentido o presente capítulo se construiu: da articulação complexa entre os achados do Universo Empírico e da literatura científica.

E articular é dar sentido, razão primeira da ciência, do método científico e da construção do conhecimento científico.

Pautado na metodologia cujo presente trabalho se construiu, dar sentido em informações oriundas de relações eminentemente complexas, como as do modelo pedagógico dos cursos de Enfermagem, Medicina e Odontologia, implica em trazer a luz da consciência não apenas o contexto e as informações em si. Nem também discutir de forma reducionista o que a literatura traz sobre as diversas dimensões da temática estudada.

Antes, dar sentido é olhar de perto em que e a quem este contexto e as informações referem-se. Em quanto e como são convergentes ou são divergentes para 
com a literatura. E quanto, e se esta abarca em seu corpo de desenvolvimento os questionamentos, considerações, articulações e interfaces da temática.

Por que estudar modelo pedagógico é estudar os homens e o mundo. Mundo complexo que está com homens complexos, em relações e inter-relações complexas, históricas e intersubjetivas. De sutilidade tamanha e amplidão tamanha que a tarefa de dar sentido, como já dito: tarefa própria do pensamento científico, se torna falar sobre a realidade além das aparências.

Freire $^{35}$ indica que o pensamento ingênuo caracteriza o homem imerso na realidade e que a consciência, despertada através da crítica e a reflexão sobre a realidade, faz com que o homem tome o caminho da conscientização, o qual permite sua emersão deste estado inicial para, então, fazer-se integrado com o mundo, não apenas como alguém que está no mundo.

O caminho do reducionismo tem calhas estreitas demais para abarcar esta realidade do modelo pedagógico e da humanização dos profissionais de saúde dado que se trata de uma relação. Não de um contexto dose-resposta.

Trata-se de falar de postura. E de postura humana. E de postura institucional. E de construção de mundo e mundo construído. Relação que muda de tom muda de cor, mas permanece no mesmo arcabouço do modo de produção capitalista. Seja entre docente e discente, com a estrutura universitária e a vida dos pacientes durante a graduação. Seja entre o profissional e a equipe de saúde, com a estrutura do serviço de saúde e a vida dos pacientes após a graduação. 
Reduzir é incorrer no mesmo erro que a Educação Bancária. É tomar a realidade como algo estático, em que relações causais e isoladas podem revelar o motivo de ser de cada coisa e de cada manifestação.

É com esta essência que se construiu o presente capítulo: dar sentido as informações, mas não de maneira reducionista.

Faz-se mister registrar que o processo de construção histórico-social como profissão é diferente em cada uma das três formações. No entanto, o presente estudo distancia-se das peculiaridades investigadas pela Sociologia das Profissões, para aproximar-se da Pedagogia, ao buscar a temática do modelo pedagógico na formação universitária em saúde e a formação humanizada, com talhe freireano, destes profissionais.

\subsection{A emersão dialógica a partir dos produtos do universo empírico}

\subsubsection{O enfermeiro, o médico e o odontólogo}

Em termos específicos, o enfermeiro é entendido como caracterizado pelo cuidar do ser humano, não apenas do cuidar no sentido biológico, mas também no acompanhamento emocional de pacientes fragilizados, por estarem no serviço de saúde. É uma profissão que luta por firmar status entre os outros profissionais de saúde.

O médico apresenta a característica de lidar com a vida humana, buscando o restabelecimento da saúde. Neste processo, se vale de atributos e conhecimentos profissionais pautados nos aspectos biológicos da saúde. É uma profissão de status 
social e alta hierarquia entre os profissionais de saúde, tendo inclusive influência política em sociedade.

O odontólogo é percebido como um profissional tipicamente liberal, de status social, pautando sua prática no mercado, sendo referido que o odontólogo é um prestador de serviços a quem pode pagar.

De maneira similar, todos os três grupos apresentaram que, fazer saúde é agir além dos aspectos biomédicos, mas também na complexidade do paciente, apesar de não mencionarem qualquer forma de operacionalizar este conceito ou de articulação entre esse e a prática do profissional.

Outra percepção em comum entre os três grupos, é que o SUS é desumanizador, dado o processo de trabalho, deficiências e grande demanda por atendimento, responsabilizando o sistema por não permitir que o profissional atue de maneira humanizada. Ainda os três grupos silenciaram sobre as particularidades do PSF como modelo de atenção que reorganiza o SUS e que se enfoca no atendimento integral e humanizado do paciente.

A autoridade do profissional de saúde sobre a necessidade do paciente foi aludida por todos, sendo que esta autoridade se manifestou na Enfermagem como o cuidado a pacientes que estão fragilizados e desconhecem como se curar; na Medicina como a postura prescritora de padrões e atitudes saudáveis aos pacientes que não detém o conhecimento médico; e na Odontologia no discurso de culpabilidade do paciente pelo seu desconhecimento em saúde bucal e na centralidade do odontólogo para restabelecer a saúde oral. 
Apesar de todas as três formações mencionarem a importância da relação horizontal com os pacientes no processo terapêutico, de maneira contraditória a este discurso, desconsideraram como válidos os conhecimentos próprios dos pacientes, oriundos de sua vivência, de seu entorno sócio-cultural, de sua tradição e resistência como oprimidos na sociedade que os oprimem.

A postura autoritária permeou os discursos, não apenas com relação ao paciente, mas também com a equipe, na qual o enfermeiro percebe-se como líder da equipe pelas questões da gestão e da administração, o médico percebe centralidade e status frente aos demais profissionais por seu conhecimento que julga ser maior que o dos demais. Sobre a relação entre Odontologia e as demais profissões do trabalho em equipe houve silêncio nos discursos.

A dificuldade do trabalho em equipe genuíno, e não a simples atuação de vários profissionais no mesmo local de trabalho foi mencionada pelos três grupos, em especial pela Enfermagem e pela Medicina, a qual ressaltam que esta dificuldade se dá em todos os níveis da atenção, não apenas na atenção primária.

Em especial, sobre a atuação profissional frente ao paciente no serviço de saúde, a Enfermagem apresenta a perspectiva de ser o profissional que mais próximo do paciente está.

Prevalece o discurso o discurso dos acadêmicos de Medicina sobre o médico enquanto profissional central do trabalho em saúde, o que é contraditório com o discurso do médico ser entendido como um profissional que não apenas deve se articular aos demais profissionais de saúde, como também deve promover o 
articulação com setores não apenas da saúde, enfocando sua atuação na intersetorialidade.

Sobre o trabalho do odontólogo, ficou registrado que não possui um modelo compatível como uma prática coletiva que se paute em operacionalizar saúde pública.

A literatura aponta que um caminho para a reversão destas perspectivas tradicionalistas e hierarquizadas no âmbito do trabalho multiprofissional é a participação dos próprios trabalhadores de saúde no planejamento das ações, como um instrumento de resgate de cidadania dos mesmos, na medida em que, ao discutir seu processo de trabalho, se tornam mais críticos e reflexivos, além de haver espaço em que tem voz e deliberam sobre sua própria condição de trabalhador e na condição de outras pessoas, de forma democrática ${ }^{113}$.

Cada vez mais as políticas públicas de saúde preconizam a abordagem dos aspectos complexos da vida do usuário do serviço de saúde e a atuação dos profissionais de forma distante do reducionismo biomédico, se fazendo mister a horizontalidade e a flexibilidade nas decisões ${ }^{114}$.

A presença de diversos profissionais de maneira desarticulada, em que realizam ações isoladas e justapostas, não abrange na completude a realização da integralidade como uma manifestação genuína nas equipes de saúde ${ }^{115}$. Está é uma situação arraigada no processo de trabalho em saúde, que há evidências de que os profissionais de saúde da família atuam mantendo a atenção curativa, individual e fragmentada, o que pode ter implicado na resistência destes profissionais em discutir o trabalho pela lógica do PSF ${ }^{116}$. 
Dadas as características do trabalho atual em Saúde Coletiva e no âmbito do SUS, a interdisciplinaridade deve ser foco de ações a serem implementadas dado que o trabalho deve ser realizado em equipe, com visão crítico-social e também técnica ${ }^{117}$, o que aponta para as dificuldades em implementar o PSF como idealizado na prática cotidiana dos profissionais de saúde da família, inclusive pelo desconhecimento e falta de capacitação dos profissionais de trabalhar na lógica do modelo ${ }^{116}$.

Outra dimensão da questão é que os profissionais de saúde da família, em áreas com grande demanda por serviços, acabam assumindo muitos trabalhos que não Ihes são característicos, o que induz a se tornarem multifuncionais, e que nestes ambientes o acolhimento é um fator extremamente desgastante para o profissional, dado a falta de tempo para suprir todas as necessidades impostas pela grande demanda $^{118}$

A conquista de direitos à saúde que se pautem em uma perspectiva menos biologista e muito mais político-social não garantiu a realização destes direitos havendo necessidade de desenvolvimento de consciência sanitária em todos os envolvidos e de efetiva participação dos usuários em todos os níveis de atenção, podendo ser esta reflexão articulada tanto com o SUS e seu gerenciamento, como em espaços políticos menores, tal como a Unidade de Saúde da Família ${ }^{46}$.

Estratégias pautadas na Educação para a Saúde devem ser preconizadas, dadas a distância entre o PSF idealizado e o PSF de fato. No entanto, há necessidade de que até esta temática seja revista, dado que a Educação para Saúde é tomada no cotidiano em saúde da família por uma lógica behaviorista responsabilizando o paciente pela doença e tomando as ações de educação em saúde em uma perspectiva tradicional, 
verticalizada e 'depositária'116. Existem experiências de superação deste modelo, com o uso de dramatização e reuniões dialogadas sobre temas de saúde como ferramentas para a promoção de saúde em um paradigma de integralidade e horizontalidade junto ao paciente que neste processo é valorizado e tem importância singular ${ }^{119}$.

As diversas necessidades e desafios na formação e capacitação de recursos humanos para a implementação do SUS efetivamente podem ser superadas com a utilização de novas tecnologias de educação, tal como a Educação à distância mediada pela internet $^{120}$.

O uso do diálogo em Educação para Saúde é uma ferramenta importante na consecução da integralidade no PSF, dado que dialogando há o respeito aos aspectos de intersubjetividade por reconhecer o paciente como sujeito do processo e não como objeto, sendo um importante instrumento humanizador, sensibilizador e que promove o estabelecimento de vínculo ${ }^{13}$.

Como afirmado anteriormente, a simples menção de que se utiliza Educação para Saúde não significa, necessariamente, que haja rompimento com o paradigma, haja vista que, em linhas gerais, a maior parte destas ações está baseada no foco behaviorista da medica através dos programas de prevenção, que se pautam em uma perspectiva biomédica e reducionista. Há necessidade de novas estratégias de promoção de saúde baseadas no empoderamento da população e nos aspectos sóciopolíticos e culturais.

Não existem certezas se a aderência do paciente ao tratamento é apenas relacionada a fatores comportamentais e de educação, mas também de sua interação com o corpo clínico, e em quanto esta interação influencia mais ou menos ${ }^{122}$. 
A construção de interdisciplinaridade em saúde não apresenta apenas o componente cognitivo próprio da temática, mas também a implicação de dimensões pessoais para a consecução, tais como a intersubjetividade, o diálogo, o respeito ao outro $^{123}$.

Com relação à inadequação da formação em saúde e a prática, defende-se que a reestruturação dos currículos de graduação e pós-graduação em saúde devem primar pela interdisciplinaridade como fato, não apenas como ideal a ser alcançado, de forma a se refletir na própria formação dos profissionais ${ }^{117}$.

Muitas vezes os pacientes se sentem intimidados a não revelar seus sentimentos sobre a forma como são tratados em serviços, por temerem ser maltratados pela equipe. Também aponta para a atuação eminentemente técnica dos profissionais de saúde nos serviços, apontando para a falta de formação pautada no relacionamento interpessoal ${ }^{124}$.

Neste contexto, o projeto de vida de cada profissional de saúde, enquanto indivíduo interfere em sua postura profissional cotidiana mais ou menos humanizada e ética $^{125}$.

A literatura científica apresenta que, no âmbito do atendimento humanizado, a dor não apresenta apenas a dimensão física, mas também sentimental e emocional, e que os profissionais de saúde muitas vezes não apresentam formação que os capacite para este entendimento complexo, desconsiderando as dimensões da dor que não são físicas, subestimando ou supervalorizando a dor e suas manifestações ${ }^{126}$.

O controle social é uma temática que apresenta um claro caráter pedagógico que pode ser utilizado na consecução da formação do profissional de saúde, uma vez 
que sua prática somente é possível dentro de um paradigma divergente do modelo biomédico, inclusive pela questão da participação do paciente nas decisões sobre saúde ${ }^{11}$.

Os profissionais de saúde ainda apresentam uma formação em que se orienta por conceitos antropológicos sobre cultura hegemônicos na década de 1960, em que a cultura do outro, no caso o paciente, é tomada como um saber 'exótico' ou primitivo, na medida em que há uma supervalorização do conhecimento biomédico ${ }^{127}$.

As profissões de saúde apresentam a peculiaridade de lidar com a vida humana, de forma que não podem ser analisadas da mesma forma que outras profissões que não apresentam esta característica ${ }^{128}$.

Um grande fator de risco psicossocial encontrado no trabalho nas equipes de saúde da família a falta de capacitação e formação para os profissionais lidarem com as exigências do processo de trabalho no modelo de Saúde da Família ${ }^{129}$.

A literatura apresenta que, de todos os aspectos do cuidado de Enfermagem, os subjetivos são os mais difíceis de serem implementados, na medida em que a rotina diária e complexa que envolve o setor faz que os membros da equipe de Enfermagem, esqueçam, muitas vezes, da aproximação do paciente, de tocar, conversar e ouvir o ser humano que está à sua frente ${ }^{44}$.

Há descompasso entre a formação do enfermeiro no ensino superior para a atuação em serviços que necessitem uma percepção complexa do paciente, o que revela a fragmentação dos saberes difundidos pela Universidade, um despreparo que se torna mais evidente quando se enfoca esta formação e a atuação deste profissional em serviços em que o paciente apresente sofrimento psíquico ${ }^{130}$. 
Investigações apontam que, sobre os conceitos das enfermeiras de saúde da família sobre universalidade, equidade e integralidade, existe premente necessidade de avaliação e reformulação dos projetos e modelos pedagógicos que vêm sendo utilizados na formação do profissional de saúde, na medida em que os achados retrataram a memorização de parte dos conceitos, dificuldades em articulação com a realidade, e distanciamento dos significados originais.

O enfermeiro possui dificuldades em articular sua prática com as questões sociais, inclusive pelo pouco entendimento teórico sobre estas, segundo a literatura ${ }^{131}$. Em estudo com as enfermeiras da assistência, as mesmas indicam a importância da intersubjetividade e de recursos para a prática que não se referem apenas aos aspectos técnicos em Enfermagem, para a produção do processo de trabalho em saúde ${ }^{132}$.

Quanto ao médico, na atuação em PSF apresenta dificuldades em pautar sua atuação da forma com que o programa foi idealizado, dado que o médico pauta seu trabalho no conceito biomédico, o qual mostra inadequações ao PSF, como por exemplo, a atenção fragmentada em especialidades ${ }^{133}$.

A prática da Medicina pressupõe o respeito a valores e ao indivíduo em todos os seus aspectos. Define desumanização como a violação do homem e de sua humanidade, não apenas nos aspectos clínicos, mas também por não considerar as demandas dos pacientes, e que o ensino em Medicina não permite que o médico seja formado nesta perspectiva humanizadora ${ }^{134}$.

Há dificuldade do médico se articular em um trabalho interdisciplinar, necessária a perfeita consecução do PSF, não apenas por sua deficiência quanto a isso 
no processo formativo, mas também pelo silencia mesmo em documentos oficiais sobre o Programa do como fazer interdisciplinaridade no trabalho em Saúde da Família ${ }^{133}$.

Em estudo sobre a conceituação do "ser médico" em alunos de graduação e de residência médica, o significado foi apontado como o profissional que primar por ser técnico e humano, tanto na doença como na morte do paciente ${ }^{135}$.

As diretrizes de atuação médica no PSF no documento de 1997 do Ministério da Saúde prima pelo médico generalista, que em como competência atender todas as famílias, havendo certo retrocesso quando são apontadas novas diretrizes em 2000, retornando a figura do clínico geral. Há problemas com a adequação da atuação médica no PSF, uma vez que este se propõe a implementação de práticas substitutivas as práticas tradicionais em saúde, e a atuação médica deve, portanto, se pautar no em novos modelos de atuação, não simplesmente no retorno a prática médica do clínico geral, que tem o conhecimento básico de todas as especialidades ${ }^{133}$.

É premente o encaminhamento de medidas de conscientização, tanto da equipe de saúde como dos usuários, para reverter o quadro de centralidade e dependência da figura do médico (medicalização) que é predominante na atualidade, o qual corrói a estrutura do $\operatorname{SUS}^{23}$.

O médico de PSF apresenta características de atuação diferentes do médico tradicional inserido nas outras especialidades, atuando da mesma forma no sentido técnico científico-restrito, mas de forma diferenciada no sentido amplo das relações sociais $^{133}$. 
Em pesquisa realizada no Estado do Rio de Janeiro, de maneira geral, a maioria dos acadêmicos em saúde demonstra não ter maturidade/visão social, considerando que os problemas de caráter sanitário e sócio-econômico não lhe competem e não se identifica com os problemas dos estratos sociais menos favorecidos economicamente, mesmo que os paciente/clientes que atendam no ambiente universitário sejam oriundos predominantemente desses estratos ${ }^{136}$.

A literatura aponta que a atuação do odontólogo demanda vínculo entre profissional e paciente. No entanto, os aspectos psicológicos desta relação não envolvem apenas este vínculo, mas também fatores próprios da ação do odontólogo, tais como o medo, a dor, situações emergenciais, incertezas diagnósticas e prognósticas $^{136}$.

Mesmo no setor público, ao qual teria por obrigação a resolução dos problemas de saúde, conforme o artigo 196 da Constituição, o modelo de assistência à saúde bucal praticado é marcado pela prática tradicional não resolutiva, pautando-se pela reprodução da prática liberal da Odontologia ${ }^{137}$.

O odontólogo tem sua formação pautada em um modelo esgotado até mesmo pela crise do mercado de trabalho em Odontologia, em que a prática particular dos consultórios, principalmente nos grandes centros, não apresenta um retorno financeiro compatível com a dedicação exclusiva a esta modalidade de trabalho, de forma que os odontólogos buscam postos de trabalho no serviço público de saúde ${ }^{77}$.

A literatura científica aponta que a atuação dos serviços públicos odontológicos apresenta talhe pautado em atos curativos e mutiladores ${ }^{138}$. 
Questiona-se sobre a existência de modelos preventivos em Odontologia adaptados aos conceitos implicados no PSF, uma vez que as ações preventivas tradicionais pautam-se em relação verticalizada entre odontólogo e público alvo, primando pelas palestras e a narração de conteúdos, que devem ser memorizados pelos pacientes, distanciando-se de uma prática que possa ser transformada em empoderamento $^{139}$. Entre os odontólogos que atuam em Saúde da Família há despreparo para atuação frente ao modelo, sendo a formação acadêmica orientada para a prática em consultório particular ${ }^{139}$.

\subsubsection{O modelo pedagógico na formação do enfermeiro, do médico e do odontólogo}

O modelo de educação bancária foi predominante nos três cursos de graduação, havendo características da educação tradicional na maioria do quadro docente, como a verticalidade na relação, a narração de conteúdos como principal ferramenta pedagógica, a ação silenciadora dos docentes para com os discentes, além da falta de comprometimento com o processo ensino-aprendizagem.

Em relação à teoria, do aluno é esperado que corrija por si mesmo as possíveis lacunas no conhecimento que eventualmente possam existir. Com relação à prática, na medida em que a faculdade não ensina tudo, é necessário que o discente procure o estágio extracurricular.

Outra característica percebida nos três cursos é a segregação entre teoria e prática profissional, não apenas em momentos distintos durante a graduação, mas também na falta de articulação da formação universitária com a realidade profissional. 
Inexistem medidas educacionais orientadas para a humanização dos futuros profissionais, quadro agudizado pelo fato de que o acadêmico não é entendido no processo ensino-aprendizagem como um ser humano complexo, histórico e social pelo docente. Pelo contrário: o modelo pedagógico pauta-se principalmente na formação técnica e não humanística dos futuros profissionais.

A postura dos profissionais enfermeiros, médicos e odontólogos que convivem com os acadêmicos foram apresentados nos três grupos como fator modulador da própria postura após a graduação.

Em particular para o grupo de enfermeiros e de médicos, o hospital ainda é o principal espaço de referência no modelo pedagógico, e suas características desumanizadas são, em certa medida, trabalhas como formas de conduta que o futuro profissional irá assumir. No que tange a Odontologia, o consultório particular ainda é o modelo pedagógico implicado na formação.

Existe grande desafio para as instituições formadoras dos recursos humanos em saúde, na medida em que cada vez mais se mostram necessários profissionais de saúde críticos-reflexivos, com habilidades além da técnica, dado que as instituições ainda enfocam muito mais a dimensão técnica da formação ${ }^{140}$.

A interdisciplinaridade no ensino superior em saúde não se constitui como uma realidade que possa vir de fora da universidade, mas sim que deve nascer entre os docentes, dado a importância de características pessoais no processo ${ }^{123}$.

Na prática docente cotidiana, muitas vezes o professor universitário se esquece de humanizar a relação com o aluno privando-o e também ao docente a oportunidade de experenciarmos o discurso que defende ${ }^{140}$. 
A Universidade ainda é um espaço tradicionalista, e que há urgente necessidade se abrir o debate para perspectivas de pesquisa mais amplas e atuais ${ }^{141} .0$ educando ainda vivencia uma dicotomização, que pode ser incorporada ao profissional que virá a ser, entre o que é ensinado a cerca do considerar o ser humano na prática profissional e como se dá esta realidade na prática, na medida em que eles próprios não são considerados em sua dimensão humana, com seus anseios, problemas, dificuldades e fragilidades durante o processo ensino-aprendizado. No contexto da formação, os educandos são instigados a desenvolver ações integrados no cuidado do paciente, por não encontrarem espaços para atender o ser humano em sua dimensão integral, pelos próprios educandos ${ }^{140}$.

A formação crítico-reflexiva é um processo no qual se constroem competências, em dimensões formais da profissão, mas também políticas, sendo que esta formação implicará em postura crítico-reflexiva no transcurso da vida profissional posterior a graduação, indicando a operacionalização desta formação através de currículos integrados entre ensino-serviço-comunidade em que o espaço de ensino não se limita a universidade ou ao estágio universitário, mas extrapola estes limites para a realidade dos serviços de saúde e para junto da comunidade, provocando a reflexão contínua e problematizada do cotidiano profissional, mesmo nos primeiros momentos da graduação $^{142}$.

Apesar da importância, não bastam apenas disposição e sensibilidade do corpo docente para promover a reorientação do ensino de graduação para os ideais debatidos na presente tese, dado que existência desafios intrínsecos ao processo de 
mudança de paradigmas, tais como a estrutura universitária e o mercado, que muitas vezes resistem à mudança de postura do docente $\mathrm{e}^{143}$.

Há necessidade de que o ensino universitário esteja contextualizado com as Políticas Públicas de Saúde e pautado no desenvolvimento de um comportamento ético-político nos futuros profissionais ${ }^{144}$.

A existência de estágio curricular em saúde da família é uma medida pedagógica importante para formação integrada à equipe de saúde, humanização e contextualização dos princípios teóricos do PSF, além da imersão nos aspectos sociais e econômicos dos pacientes, podendo contribuir para a construção de profissionais pautados em conceito sobre o processo saúde-doença com dimensões bio-psicosociais e não apenas no modelo biomédico ${ }^{145}$.

A formação universitária em saúde apresenta suas raízes na tradição pautada na fragmentação do conhecimento, emblematizada pelo Relatório Flexner, documento norte-americano que foi elaborado nas primeiras décadas do século XX, o qual preconizava unificação dos currículos médicos e aportes oriundos do conceito biomédico sobre saúde, panorama que será hegemônico até a década de 1990 quando tomam vulto movimentos por modelo formador e prática sob o paradigma do processo saúde-doença e seus determinantes ${ }^{48}$.

Há indícios que, ao se investigar a questão da avaliação em graduação, que os docentes ainda preservam predominantemente métodos avaliativos que priorizam a mensuração educacional, a avaliação classificatória, a quantificação de aprendizagem, tomando como parâmetro os conteúdos programáticos e a memorização dos mesmos $^{146}$ 
Há falta de formação didático-pedagógica dos docentes no ensino superior em saúde, os quais apresentam conhecimento deficiente em termos de conceitos básicos em avaliação e ausência de postura crítico-reflexiva a respeito de sua atuação frente as questões pedagógicas nos cursos de graduação em saúde ${ }^{146}$.

Para formação integral do profissional em saúde envolve o desenvolvimento de habilidades psicomotoras específicas de cada profissão, assim como habilidades afetivas apropriadas $^{147}$.

A prática e o ensino em saúde não estão desvinculados da realidade e de sua vertente política, econômica e cientifico-tecnológica, sendo necessária a formação de profissionais críticos-reflexivos que estejam conscientes destas dimensões da realidade, que interferem sobremaneira na sua atuação profissional ${ }^{148}$.

Para a construção de modelos curriculares pautados na interdisciplinaridade é necessária a reformulação integrando conteúdos e com enfoque problematizador, desencadeando discussões, estudo e leituras não apenas biologicistas, mas também nas dimensões social e psicológica do paciente ${ }^{149}$.

É necessário que os cursos universitários se adéqüem sua estrutura para que os acadêmicos se preparem para o período transitório entre a graduação e sua inserção na prática posterior a mesma ${ }^{150}$.

Novas ferramentas pedagógicas se fazem necessárias. Neste sentido, o uso de entrevista de acadêmicos à pacientes do serviço assim como a observação do cotidiano, articulado com reflexões éticas provocadas pelo corpo docente, pode ser constituir como ferramenta para a formação em um modelo biopsicossocial distanciando a Universidade do paradigma biomédico ${ }^{151}$. 
Há premente necessidade da superação do referido modelo Flexneriano na formação em saúde pelo direcionamento crítico-reflexivo ${ }^{152}$.

A orientação da política educacional no processo de reformulação curricular em saúde é importante, mas que neste contexto não pode ser esquecido a importância da atitudes, crenças, interesses e ideologias dos atores envolvidos, dado que são pessoas que fazem atuam neste processo, e estas dimensões individuais interferem significativamente na condução ${ }^{153}$.

Para a transformação genuína, os professores universitários devem apresentar uma postura coerente como os novos paradigmas necessários a uma educação superior pautada na criticidade e na reflexão, agindo com uma postura dialógica e que se valorizam os múltiplos saberes, não apenas os saberes técnicos ${ }^{154}$.

Os educadores em saúde devem primar pela reflexão e pela prática reflexiva, buscando trabalhar junto aos estudantes estes parâmetros de forma que eles possam agir e pensar em suas profissões de maneira integrada, articulando teoria e prática ${ }^{155}$.

Existem experiências que apontam para a necessidade do envolvimento dos próprios estudantes na promoção de saúde em escolas, processo no qual a instituição de ensino passou a se tornar um ethos de cidadania, ao unir estudantes, docentes e comunidade, promovendo o desenvolvimento de um perfil profissional com vistas a integralidade, na medida em que os estudantes se tornaram atores ativos, desde de serem ouvidos na organização e administração da instituição, até no estabelecimento de intersetorialidade com outros segmentos sociais para a consecução da experiência ${ }^{156}$. 
Há necessidade da superação do predomínio dos professores mais preocupados com o ensino técnico do que com um ensino que conjugue a técnica com a formação de uma postura crítico-reflexiva no aluno, sendo assim uma formação ainda tecnicista e biologicista ${ }^{157}$.

Daí o distanciamento entre a Academia e a prática que o graduado encontra em seu dia-a-dia.

Há que se ressaltar que a Universidade tem um papel social quando da formação dos enfermeiros e, neste papel, deve primar pela pesquisa e pelo ensino, mas também articulá-lo a questões da vida humana, tais como o impacto dos resíduos sólidos do trabalho em saúde no meio ambiente ${ }^{158}$.

Ao investigar o atendimento em Enfermagem, a literatura apresenta que a assistência e o cuidado de saúde centrados na família são percebidos pelas enfermeiras como uma situação ideal para os serviços de saúde, mas sua implementação e prática ainda são dificultadas na medida em que ainda não existem métodos bem delimitados e estabelecidos que permitam esta abordagem da atenção. Entre as dificuldades está a necessidade de que se ofereçam espaços formativos para o desenvolvimento de habilidades para que os enfermeiros possam lidar, inclusive, com situações de crise, para as quais não estão capacitadas. Não é uma realidade aplicável apenas a pratica da Enfermagem. Isto ocorre também em outras áreas de formação, particularmente na Medicina e na Odontologia, profissões que o presente estudo também levou em consideração ${ }^{159}$.

Existem problemas na consecução real do trabalho em equipe de saúde, mesmo quando observado apenas a equipe de Enfermagem, e em contextos nos quais 
se declara ação com gestão participativa, não existindo nem mesmo cooperação coletiva. O ensino em Enfermagem deveria atentar para isso, mudando a formação para que o enfermeiro egresso, não apenas gerenciasse a equipe de Enfermagem com enfoque tradicional, mas conseguisse articular-se com a equipe, para efetividade no trabalho coletivo. O currículo de Enfermagem deveria ser reformulado com vistas a outros saberes, tais como o da gestão e do comportamento humano nas $\operatorname{organizações~}^{160}$.

Identifica-se a necessidade a necessidade de problematizar o ensino de Enfermagem. Realizando-se pesquisa ${ }^{161}$ em que a aprendizagem de acadêmicos do curso de Enfermagem com relação aos cuidados com paciente hansênico foi promovida contando no processo com a participação de pacientes portadores da patologia, os quais relataram suas experiências e trajetórias de vida, constataram-se ganhos ímpares. Pautou-se a experiência na relação entre acadêmicos e portadores, o que, segundo ao autor, propiciou a tomada de consciência e o desenvolvimento de capacidades e habilidades para a ação do enfermeiro, valorizando o auto-cuidado assim como o cuidado profissional. No processo, os portadores discutiram com os acadêmicos a problemática, de forma que a construção de ensino propiciou a conscientização e o empoderamento, tanto dos acadêmicos como dos próprios portadores.

Em estudo ${ }^{162}$ realizado com 13 cursos de Enfermagem de IES do município de São Paulo, apresenta que apesar de 59\% das disciplinas referirem-se a intenção de humanização dos futuros profissionais nas IES investigadas, apenas duas disciplinas de uma IES poderiam proporcionar o ensino deste tema, articulando conteúdos das 
humanidades a ciência de saúde aplicada, o que denuncia uma inadequação entre a proposta de um ensino humanizador e sua real implementação.

Há descompasso entre a formação do enfermeiro e a prática profissional, denunciando que as mudanças curriculares em Enfermagem aconteceram e continuam acontecendo distantes da realidade e do cotidiano. E mais ainda: sem um dimensionamento prévio dos impactos que estas mudanças poderão ou não ocasionar na sociedade ${ }^{163}$.

A formação de enfermeiros críticos, politizados e de real atuação social, mesmo com as reformulações curriculares dos cursos universitários, ainda permanece na retórica, na medida em que se fazem alterações pontuais ou na ordem das disciplinas, quando o que se precisa são de mudanças no modelo formativo "rompendo o velho, em busca do novo"163.

O ensino em Enfermagem ainda prima pelo talhe tradicional, mesmo em uma época em que os avanços em educação direciona-se ao uso de tecnologias de comunicação, como no caso do ensino a distância, que em seu estudo demonstrou ser totalmente aplicável, mesmo em áreas como a Enfermagem Psiquiátrica que na maioria dos currículos em Enfermagem ainda apresenta-se com orientação retrógrada frente aos avanços mencionados e a necessidade do profissional no cotidiano ${ }^{164}$.

Deve haver integração entre docentes, enfermeiros assistenciais e discentes durante o processo de formação do profissional de Enfermagem com vistas a melhor qualidade do ensino, principalmente no que se refere a dimensão profissionalizante do curso, tal como nos Estágios Curriculares ${ }^{165}$. 
Não se trata apenas de uma constatação de quem ainda está na academia, ou dos docentes que participam do processo. Os egressos do curso de Enfermagem apontam para a necessidade de modelos formativos que primem pela interdisciplinaridade ${ }^{144}$.

A discussão sobre a necessidade de novos modelos de formação em Enfermagem torna-se mais contundente principalmente em áreas tais como a Saúde Mental, em que o princípio da autonomia do paciente no tratamento ainda é um avanço que está em caminho de consecução, e o direcionamento do enfermeiro psiquiátrico para o enfoque comunitário ainda é uma barreira a ser superada para a maioria dos serviços, que primam pelo enfoque da especialidade e não da interdisciplinaridade ${ }^{166}$.

Na questão da fragmentação entre a teoria e a prática, aumenta-se a carga horária desta última dimensão no currículo, mas não há uma reformulação profunda, haja vista que os estágios, durante a formação do enfermeiro, ainda primam pela valorização sobremaneira do componente técnico ${ }^{167}$.

Existe deficiência na formação do enfermeiro para atender a família enquanto tal, em contextos como o PSF e que as próprias enfermeiras deste modelo indicam a importância deste enfoque, pautado na visão da Enfermagem como prática social e que existe necessidade de a formação do enfermeiro para esta prática ${ }^{168}$.

O traço marcante do perfil profissional do enfermeiro, que o distingue dos demais profissionais da equipe de Enfermagem e dos outros profissionais de saúde, mesmo no modelo atual, está no gerenciamento e administração dos serviços de saúde ${ }^{169}$. 
Os alunos de Enfermagem apontam dois perfis de professores universitários: o aberto, dialógico, problematizador - que realmente ensina; e o autoritário, adialógico, tradicional - que não ensina ${ }^{170}$.

A aula expositiva como principal ferramenta utilizada no curso de Enfermagem, segundo depoimentos de professores e alunos, os quais enfatizam o desinteresse e desmotivação desta modalidade ${ }^{170}$.

Desconsidera-se no modelo tradicional, que o genuíno trabalho em grupo durante a graduação em Enfermagem facilita a troca de experiências, o que se mostra importante principalmente nos momentos em que os acadêmicos vão para a prática, dado sua insegurança e dificuldades, que se externalizadas e ouvidas podem se constituir como momento humanizador, na medida do cuidar do outro, característica da Enfermagem como profissão ${ }^{171}$.

O modelo formador em Enfermagem é pautado no modelo biomédico, priorizando o ensino terapêutico e tecnológico, necessitando de ajustes para que o acadêmico possa identificar e lidar com situações de cotidiano articuladas com o desenvolvimento de capacidade de reflexão ética e reflexão de valores ${ }^{125}$.

Deve ser percebido pelas IES, e agido no contexto, que entre a formação e a prática do enfermeiro, existe uma dicotomia e incoerência entre a ensino e serviço, que se pautam em uma lógica dos modelos tradicionais, tanto no setor do Ensino como no setor da Saúde ${ }^{172}$.

As mudanças nas Diretrizes Curriculares para os cursos de Enfermagem encaminham para a superação da fragmentação da formação do enfermeiro, apesar 
dos cursos de graduação ainda apresentarem dificuldades em implentar as referidas diretrizes $^{173}$

Este debate, da formação do enfermeiro representar a prática profissional, é um desafio mesmo nos países de primeiro mundo. Defende que esta problemática é modulada pela estruturação do curso, modelo pedagógico empregado, conteúdos, enfoque dado a questões sentimentais e emocionais, corpo docente ${ }^{174}$.

Como exemplo, os cursos de formação em Enfermagem nos países europeus apresentam como um dos desafios a adequação desta formação as constantes mudanças em seus sistemas de saúde, havendo necessidade de que o egresso esteja preparado para atuar frente ao sistema ${ }^{175}$.

Este debate evidencia que há disparidade entre o currículo idealizado e o que se dá de fato na formação de enfermeiros, inclusive apresentando aspectos como a importância das ciências biológicas para esta formação mas que ainda existe descompasso e falta de articulação entre a forma com que estas ciências são ministradas e as reais necessidades para a prática em Enfermagem ${ }^{176}$.

O contexto refere-se também a questão de que a base de conhecimento de Enfermagem, consolidada a partir dos anos de 1960, é orientada para as ciências biológicas e comportamentais, o que dificulta a formação holística do enfermeiro, dada a fundamentação epistemológica da formação profissional em Enfermagem. Neste contexto, promove-se uma formação em que a teoria é dicotomizada com a prática, além de um 'holismo incompleto' ${ }^{121}$.

Para se promover mudanças curriculares efetivas em Enfermagem é necessário que os docentes tenham formação pedagógica crítico-reflexiva, atuando de forma 
integrada entre a promoção de saúde para o cidadão, para a família e para a comunidade, articulando ensino e assistência em novo paradigma ${ }^{177}$.

Já na formação médica ${ }^{178}$, esta é exígua em fundamentos e na transmissão de valores humanísticos, com parco entendimento de conhecimentos das ciências humanas. Neste processo, faz-se mister a consolidação de conhecimento e habilidades na formação da relação profissional e paciente/cliente que venham de acordo com os pressupostos freireanos ${ }^{35,36}$ nos quais se destaca a relevância da amorosidade e do afeto entre educador e educando. Isto pressupõe, portanto, o mínimo para o desenvolvimento do processo de humanização.

Nos currículos de Medicina há o ocultamento de aspectos importantes da formação do médico, tais como a morte ${ }^{179}$. O modelo de formação médica, tal qual conformado tradicionalmente preconiza o distanciamento das emoções para o ganho em conhecimento da prática médica, ocasionando a expropriação da subjetividade do profissional durante o processo terapêutico, havendo premente necessidade de reordenação da base filosófica dos cursos ${ }^{135}$.

As mudanças curriculares empreendidas nos currículos médicos não resultaram em mudanças de atitudes significativas nos estudantes de Medicina ${ }^{178}$. Neste sentido, há exigüidade de formas avaliativas sobre habilidades e atitudes dos acadêmicos de Medicina, dificultando o processo de avaliação do ensino de graduação médica ${ }^{179}$.

Um aspecto que modula este contexto é a formação universitária.

No que se refere ao odontólogo, há incoerência entre futuros profissionais de Odontologia que sirvam aos ditames do capital, trabalhando para uma parcela de 
menos de dez por cento da população, que pode pagar pelos seus serviços odontológicos particulares ${ }^{136}$.

A formação acadêmica em Odontologia é deficitária mesmo em temas mais tradicionais de saúde coletiva tais como as políticas públicas de saúde bucal, desenvolvendo no aluno a visão fragmentada sobre as políticas públicas de saúde bucal. Muitas vezes, nem mesmo conhecimento aproximativo do tema ${ }^{136}$.

Há necessidades de profunda discussão, democrática e pautada na cidadania, entre alunos de Odontologia, professores e as IES sobre estes problemas na formação em Odontologia, rompendo com a visão do aluno como elemento passivo, uma vez que esta postura se refletirá na formação de um odontólogo passivo as questões do entorno sócio-cultural que o cercam ${ }^{136}$.

As IES e os serviços de saúde devem fortalecer a atuação da categoria dos odontólogos de forma mais contundente e relevante em termos políticos e sociais. A formação do odontólogo deve orientar-se para a construção de um profissional críticoreflexivo e atuante junto às questões sociais, empenhado e implicado na concretização dos princípios e diretrizes do SUS, com enfoque na atenção primária ${ }^{180}$.

A reforma universitária em Odontologia deve primar pela integração entre formação, exercício profissional e política social ${ }^{181}$.

O PSF promoveu uma ampliação da cobertura odontológica para a população assim como uma expansão no número de postos de empregos para os odontológos. No entanto, os autores discorrem que há problemas para que os odontólogos atuem em conformidade com a filosofia do programa, uma vez que a formação odontológica os prepara para as questões biológicas, ações curativas e para o desenvolvimento de 
habilidade técnica, com lacunas quanto a formação enfatizando aspectos socioeconômicos e psicológicos dos pacientes, tanto quanto a pouca formação no que se refere a promoção de saúde139.

Em investigação ${ }^{182}$ sobre o conhecimento sobre saúde bucal e quanto estes aspectos são importantes para que os ACS dado que os princípios do PSF norteiam para o trabalho em equipe junto aos diversos problemas em saúde, constatou-se a existência de desarticulação entre os odontólogos e os ACS, uma vez que estes últimos não apresentavam conhecimentos básicos sobre higiene bucal e prevenção, apesar das duas categorias profissionais indicarem como importante e de aplicabilidade estes conhecimentos na prática do ACS.

\subsubsection{Sobre as matrizes curriculares neste contexto}

Declara-se em diversos artigos das Diretrizes Curriculares Nacionais dos Cursos de Graduação em Enfermagem ${ }^{184}$, das Diretrizes Curriculares Nacionais dos Cursos de Graduação em Medicina ${ }^{185}$ e das Diretrizes Curriculares Nacionais dos Cursos de Graduação em Odontologia ${ }^{186}$ diversos princípios orientadores, comuns as três formações, tais como formar profissional com caráter generalista, humanista, crítico e reflexivo, devendo conhecer e intervir sobre os problemas/situações de saúde-doença, dimensões biopsicossociais dos seus determinantes como promotor da saúde integral do ser humano e da atenção efetivamente pautada na integralidade; assumir o compromisso ético, humanístico e social com o trabalho em equipe multiprofissional em saúde. Ressalta que esta formação deve se dar com ênfase no SUS. 
Com relação aos conteúdos essenciais ${ }^{183-185}$, ressalta-se a busca pelo entendimento e atuação frente ao processo saúde-doença do cidadão, da família e da comunidade. O caráter de aliar teoria e prática deve estar presente em toda a formação, que é composta ciências biológicas; das ciências humanas e sociais; e das ciências profissionalizantes de cada uma das profissões. Esta formação deve se dar em um modelo que articule ensino, pesquisa e extensão/assistência. Chama atenção que os conteúdos das ciências humanas e sociais devem desenvolver a reflexão do acadêmico sobre a realidade social, às diversas dimensões da relação indivíduo/sociedade, contribuindo para a compreensão dos determinantes sociais, culturais, comportamentais, psicológicos, ecológicos, éticos e legais, nos níveis individuais e coletivos, do processo saúde-doença.

A discordância das matrizes curriculares dos cursos investigados com relação a estes princípios norteadores e o produto dos Grupos Focais e entrevistas individuais corroboram com a perspectiva de falta de formação crítico-social dos acadêmicos entrevistados pautada na orientação do modelo pedagógico.

Se analisado em termos do total de créditos, o curso de Enfermagem apresenta a maior porcentagem referente a disciplinas da área das ciências humanas e de disciplinas de interface com o total de $17 \%$ de créditos, enquanto a Medicina apresenta $9 \%$ - pouco mais da metade desta porcentagem do curso de Enfermagem. A Odontologia, que apresentou as deficiências mais contundentes para uma abordagem profissional crítico-social e pautada nos princípios do SUS, apresenta apenas 3\% de disciplinas de interface inexistindo no curso disciplinas da área das ciências humanas. 
Com relação a Saúde Coletiva, a Enfermagem e a Medicina apresentaram cerca de $10 \%$ dos créditos totais nesta área, enquanto a Odontologia apenas $4 \%$.

Todos os cursos apresentaram os conteúdos de interface ou os da área de humanidades com formação eminentemente teórica e desarticulada da realidade do profissional assim como da importância para a atuação no SUS e no PSF.

No entanto, deve ser ressaltado que a formação divergente do preconizado pelas Diretrizes Nacionais supra-relacionadas não é exclusividade dos cursos investigados no presente estudo.

Ao investigar a aderência dos cursos de Enfermagem, Medicina e Odontologia às Diretrizes Curriculares Nacionais dos Cursos de Graduação ${ }^{57}$, os currículos dos cursos de graduação em Enfermagem apresentam a deficiência ao não conseguirem de maneira satisfatória permitir que o conhecimento trabalhado na universidade paute-se na responsabilidade social. Há necessidade que o corpo docente tome a interdisciplinaridade como orientação pedagógica coletiva. Com relação à Medicina, ainda evidencia-se em todo país o currículo mínimo e as práticas tradicionais. $\mathrm{Na}$ Odontologia mantém-se o modelo de formação voltado para o exercício privado da profissão e desconexão entre o biológico e o social. Para todos os cursos a desarticulação com o SUS é emblematizada pela restrição do conhecimento sobre os princípios e diretrizes aos docentes da área da Saúde Coletiva.

Outros desafios a serem superados ${ }^{186}$ nos cursos de Enfermagem: a priorização da formação técnica, o norteamento dos cursos em conformidade com os princípios do SUS, o estabelecimento do trabalho coletivo como componente vital dos cursos. Com relação ao curso de Medicina, a articulação da formação do médico com os princípios 
do SUS como principal desafio aos cursos de Medicina no país, rompendo com o modelo formador centrado no hospital. Com relação a avaliação dos cursos de Odontologia, o principal desafio está na construção de modelos pedagógicos e adequação da formação do odontólogo a realidade do SUS, rompendo com o modelo formador centrado no consultório particular ${ }^{186}$.

Os currículos de saúde, em especial o de Enfermagem e o de Medicina, devem ter dimensões humanísticas em comum, que seriam a base da construção interdisciplinar entre as mesmas para o genuíno trabalho em equipe. Sugere-se que esta base se dê em disciplinas que tenham como temas história, cinema e arte, ética, literatura, espiritualidade, legislação, filosofia e comunicação, com enfoque no empoderamento do paciente e de equipes multiprofissionais, e de forma articulada com os saberes de saúde, não a simples criação de disciplinas com estes temas ${ }^{187}$.

A centralidade da atenção primária no SUS e o enfoque contundente pela capacitação dos recursos humanos neste nível de atenção evidenciam-se no discurso governamental a exemplo das Diretrizes Operacionais contidas nos documentos referentes aos "Pactos pela Vida, em defesa do SUS e de Gestão", de 2006. Com relação as funções gerais dos membros da equipe de Saúde no PSF a superação das práticas tradicionais em saúde e a busca pela integralidade são reafirmadas como diretrizes e atribuições comuns à todos os profissionais ${ }^{187-189}$.

A crise multidimensional que assola as populações reafirma a importância da Educação e da Saúde como espaço para a transformação desta realidade, já que implicam em pensamentos, crenças e valores dos atores que vivenciam este espaço ${ }^{190}$. 
Em experiência de curso de capacitação em PSF para acadêmicos de Odontologia utilizando-se da problematização, o mesmo mostrou a pertinência com os princípios do modelo de atenção, além do interesse destes acadêmicos. Neste curso todos os conteúdos teóricos foram ministrados dentro da realidade de uma equipe de saúde da família, desde as teorias sobre políticas de saúde e sua evolução, até aspectos do PSF. Os acadêmicos declararam que este modelo seria o ideal para uso na graduação como um todo, mas principalmente junto das disciplinas de Saúde Coletiva $^{191}$.

As transformações nos modelos em saúde, dado o exposto, devem ser pautar na educação problematizadora, e não simplesmente no reordenamento de matrizes curriculares, ou o simples e irrefletido ato de aumentar cargas horárias de disciplinas. Antes, deve ser pautado nos três momentos da problematização: identificação do problema a ser investigado com fim educacional, explicação deste problema e proposição de soluções ${ }^{192,193}$.

Há relatos na literatura, sobre experiências da problematização dos conteúdos e práticas pedagógicas, acrescida da articulação destas junto aos serviços de saúde, em disciplinas da área de Saúde Coletiva no curso de Medicina tendo como resultado contribuições para a formação médica mais humanizada e comprometida com a realidade do paciente $\mathrm{e}^{70,194}$.

Na relação professor-aluno a significação do diálogo, pode encaminhar a um recurso didático e de papel humanizador na educação no ensino superior em saúde ${ }^{195}$.

Há que se ter em mente que Projetos Político-Pedagógicos são sistematizações, e não mapas definidos dos caminhos, por que a ação de avaliar, direcionar e 
redirecionar a educação deve ser um processo dinâmico e contínuo, de forma a adaptar os caminhos tomados aos problemas que surgem, adaptando a educação ao contexto em que está acontece ${ }^{196}$.

Outra questão educacional é que a atribuição de notas é uma ferramenta de opressão dentro da educação tradicional, e deve ser revista, dado que reproduz a postura autoritária do poder dominante e opressor na sociedade capitalista, servindo como instrumento silenciador dos discentes, dado que o aluno considerado bom é o que consegue boas notas e não o que age criticamente com relação a situação da educação ${ }^{197}$.

A educação, o ensino e o currículo são processuais e apresentam um caráter social, dependentes do contexto e dos atores envolvidos, sendo que o modelo que os orienta provém da interação entre os atores e as necessidades que se apresentam ${ }^{198}$.

A avaliação da educação, para surtir efeitos realmente transformadores, deve partir de alunos, educadores e demais envolvidos na educação e não apenas de especialistas, de forma que os diversos aspectos sejam debatidos entre que vivencia o processo para delimitar quais os desafios e possíveis caminhos para superação, primando pelo processo democrático ${ }^{199}$.

As reformulações dos modelos pedagógicos em Enfermagem, Medicina e Odontologia devem primar pela teoria da pedagogia crítica, dos quais Freire é um dos teóricos mais consagrados, na medida em que esta teoria se característica pela investigação sobre a temática da educação em princípios fundamentais de análise como o papel das instituições de ensino na vida política e cultural, a implicação da economia e do homem na educação ${ }^{200}$. 
Os professores devem, neste novo momento do ensino, primar pela atitude reflexiva na educação, principalmente por que o espaço do ensino é mutável na medida em que a própria sociedade é mutável e complexa. Muitas vezes os planejamentos iniciais para a prática da educação devem ser flexíveis, dado que os contextos se alteram no processo educativo e, o foco principal da ação do docente é o processo ensino-aprendizado, o qual deve promover cidadania junto aos discentes ${ }^{201}$.

A abordagem freireana da educação prima por transformações da prática docente e da estrutura do modelo pedagógico, na medida em que a construção do conhecimento deixa de ser individual para ser tomada como prática coletiva, a construção do currículo acontece a partir das necessidades históricas do campo de ensino a que é dedicado, há clara definição da orientação política do processo ensinoaprendizagem no sentido de saber de que contexto saiu a orientação e para qual transformação se deseja alcançar, e, por fim, há relação horizontal tanto do educador com os educandos, destes com os pares, como do educador, dos educandos e do mundo com o qual vivem ${ }^{190,202}$.

O ensino deve ser democratizado desde sua base, não apenas nos planejamentos, mas desde o ensino em sala, pautado na autonomia para que se formem os educandos para a vida, para o mundo do trabalho, para a humanização das relações interpessoais com eticidade e transformação social de maneira crítica, primando pela sociabilização do conhecimento. Ressalta-se a importância de levantar no próprio contexto da educação os problemas e os planos para superá-los com vistas a transformação social e implementação da cidadania ${ }^{190,203}$. 
A educação que se pauta na cidadania verdadeira implica na relação dialógica e na formação dos educandos para estas, tanto na dialogicidade entre os homens, como destes e o mundo com o qual estão, de forma que o currículo deva se basear nestas relações complexas com fins a emancipação do educando, seja na sala de aula, seja na instituição de ensino como um todo, buscando as conexões entre o saber, identidade e poder, agindo de maneira crítica junto aos educandos e desenvolvendo neles a criticidade e a capacidade de reflexão sobre este contexto ${ }^{203}$.

A verdadeira transformação na educação acontecerá quando os projetos políticos pedagógicos se revestirem e estiverem imersos no direcionamento da complexidade, tal qual aclamada por Edgar Morin, e no posicionamento críticoreflexivo de Freire, de forma que a interdisciplinaridade e a articulação do ensino com a realidade possibilitem a construção de uma educação para a cidadania ${ }^{190,204}$.

Os currículos tradicionais não permitem o desenvolvimento da criticidade no discente por que, entre outras características, há idealização dos parâmetros aceitáveis e não aceitáveis para o aluno a partir da ideologia que direciona politicamente a instituição de ensino, desconsiderando tanto a realidade e se é possível ou não articular esta idealização com esta, como também se desconsideram outros parâmetros de aprendizagem não previstos ou contrários ao que é aceitável. Sendo a realidade e a relação homem-homens-mundo complexa, não há como ser contida na perspectiva tradicional ${ }^{203}$.

De modo antagônico a perspectiva tradicional, a pedagogia crítica toma a intersubjetividade, o poder e as relações dinâmicas e mutáveis entre estas enquanto espaços privilegiados para o ato transformador, utilizando-se da educação e do 
desenvolvimento da capacidade crítico-reflexiva nos atores sociais para isso, conscientes de sua responsabilidade social, da dominação e da desigualdade no mundo ${ }^{205}$

A educação deve ser mais que apenas atualização de conhecimentos, mas sim um processo participativo, reflexivo e de formação pautada na realidade e para esta transformar ${ }^{206}$

O papel do professor frente ao ensino deve ser muito mais do que o de técnico que atua de forma prescrita, mas sim a de um sujeito ativo e crítico, que deve se engajar na verdadeira transformação através da inovação contextualizada com sua realidade, mais como facilitador da aprendizagem do que como técnico, contando com a cooperação e participação dos alunos de forma reflexiva ${ }^{206}$.

No contexto do presente estudo, a importância e responsabilidade dos docentes nos cursos de saúde são imensas, na medida em que os mesmo que decidem tanto os conteúdos como as ferramentas pedagógicas a serem utilizadas junto aos alunos $^{207}$

Em experiência de formação pedagógica em nível lato senso para docentes do ensino superior, utilizando-se de metodologia problematizadora, resultados positivos foram encontrados. Ao final do curso, foi promovida avaliação no qual os participantes apontaram a problematização como um caminho aplicável as reformulações da prática docente no ensino superior, apesar de apresentar desafios tais como a operacionalização da metodologia para as diferentes etapas da formação universitária ${ }^{195}$. 
Há que se defender o resgate do sentido de ensino nos cursos de saúde, dado a hegemonia do pensamento da transmissão de técnicas, sugerindo que este quadro se revela quando é observada a prática dos profissionais de saúde com relação à educação em saúde ${ }^{208}$.

O processo de formação pedagógica do docente é um momento especialmente importante para a construção de perfil crítico-reflexivo e não de mero técnico do ensinar conteúdos ${ }^{206}$.

Os professores deveriam se distanciar do papel de reprodutores de prescrições externas e com aportes de formação para a docência oriunda de técnicas pedagógicas tradicionais, para assumirem seu verdadeiro papel que é o de intelectuais críticos, reflexivos e criativos nos contextos sociais e culturais em que trabalham, já que cultura reflete a política e o poder ${ }^{209}$.

Frente à necessidade de reordenação da formação universitária em Enfermagem, Medicina e Odontologia os Ministérios da Saúde e da Educação ${ }^{54}$ lançaram o Programa Nacional de Reorientação da Formação Profissional em Saúde (Pró-Saúde), um modelo coerente com o pensamento freireano conforme as três fases de adaptação dos cursos as diretrizes.

\subsection{Diálogo contextualizado com os pressupostos freireanos}

Freire $^{83}$ apresenta que a educação tradicional, como a caracterizada nos cursos de Enfermagem, Medicina e Odontologia investigados, não permite que o educando experimente a diversidade da realidade e articule os conhecimentos teóricos nesta, de 
forma que há desestimulo dado a dificuldade de aplicar a teoria na prática, o que foi denunciado pelos acadêmicos, tanto coletivamente nos Grupos Focais como individualmente nas entrevistas.

A importância do educador progressista, dialógico, horizontalizado na prática educativa com o educando foi reafirmada pelos três grupos de acadêmicos, sendo referida no mesmo sentido dado por Freire ${ }^{83}$ que declara o educador democrático e problematizador como o docente que tem autoridade de fato dada a sua coerência, ética, responsabilidade e clara preocupação com o aprendizado do aluno no processo educacional.

A postura distanciada dos acadêmicos dos três cursos com relação a seu comprometimento e implicação no entorno sócio-cultural do paciente tem grande chance de refletir a postura docente e o modelo pedagógico universitário. Reflete o pensamento de que a educação é tão somente um processo de adaptação do homem a sociedade, homem este adaptável, pensamento eminentemente bancário e desumanizador, conforme Freire ${ }^{78}$.

Esta redução do futuro enfermeiro, do futuro médico e do futuro odontólogo com relação a vida do paciente remete a percepção de Freire ${ }^{83}$ sobre o envolvimento nas questões da realidade ou do distanciamento, referindo que a primeira postura revela a assistência em que os problemas sociais são vistos pelo ser profissional como reflexos da interação entre dimensão social, política, econômica e de poder; enquanto que na postura do distanciamento do profissional em considerar estes fatores está implicada a concepção assistencialista, para a qual os problemas e as características da vida dos pacientes são questões sem solução e de ordem natural, cujo papel do 
profissional de saúde reside em socorrer a emergência, mas não sanar o problema na causa. E nem mesmo pensá-lo e sobre esta última. Um agir que não respeita vocação do ser mais, do ser humano, do caráter humano de seu trabalho por que se tratam de profissionais de saúde, não simples prestadores de serviço - apesar de que esta é a percepção que os acadêmicos investigados apresentam.

E por lidarem com vidas humanas, o compromisso deve ser de promover assistência e não assistencialismo, do homem real comprometido com o homem concreto em razão da humanização de ambos, não podendo a técnica, a ciência, a tecnologia, o protocolo, instrumentos da ação, prescindir ao homem a que se destina esta ação ${ }^{78}$.

A reflexão da importância da formação do enfermeiro, do médico e do odontólogo por uma perspectiva crítico-social e orientada para o processo de trabalho em PSF não repousa apenas no dimensionar a educação superior para o que é preconizado pelo Governo Federal através de seus documentos. Antes, é reconhecer o ganho político para a cidadania e redução de desigualdades e resgatar o papel dos profissionais de saúde enquanto agentes de transformação social, dado seu lidar diariamente na subjetividade e objetividade que são emblematizadas pelo setor da Saúde enquanto potencial de transformação social. E deve iniciar pelo estudar critico do educador e dos educandos, da natureza, da sociedade, e da humanidade, com suas articulações $^{78}$ frente a profissionalização do enfermeiro, do médico e do odontólogo.

Freire $^{82}$ defende que o papel do educador frente a educação não se refere apenas ao espaço educativo, mas principalmente no onde, como, com quem e quando as construções junto aos educandos emergirão na sociedade como força motriz para a 
transformação. Em particular aos enfermeiros, aos médicos e aos odontólogos o Estado através do SUS e do PSF garantiu um espaço para que estas transformações fossem cultivadas e os princípios do SUS, que não abrangem tão somente questões de saúde, mas também de empoderamento em seu cerne, pudessem se tornar efetivos. Para isso se precisa do homem. E homens enfermeiros, homens médicos, homens odontólogos que ajam pela sua própria humanidade, junto aos homens e ao mundo. Esta é uma transposição da educação para a liberdade de Freire em educação para a saúde e o empoderamento no âmbito do SUS.

A problematização ${ }^{36}$ pode se constituir em um caminho interessante para a modulação dos cursos de saúde na medida em que parte da premissa do uso de criatividade, ação e reflexão sobre a realidade, procurando a transformação e a criação nos contextos inicialmente investigados ${ }^{77,79}$. Esta afirmação pode ser justificada na medida em que o modelo formativo pautado no conhecimento teórico, fragmentado e desarticulado com os contextos reais vivenciados nos serviços de saúde, no PSF em particular e na vida da população é característico do modelo pedagógico tradicional que vem formando enfermeiros, médicos e odontólogos, conforme debatido e criticado no transcorrer do presente estudo, distancia o educando da reflexão crítica para a do discurso teórico prescritivo de conhecimentos externos à realidade ${ }^{36}$. Problematizar é deixar de treinar enfermeiros, médicos e odontólogos para atuarem como técnicos-prestadores de serviços de saúde para então formá-los em sentido humano e não simplesmente adestrá-los em protocolos de saúde, respeitando sua vocação ontológica de ser mais, conforme a perspectiva freireana ${ }^{77,81}$. 
Ao problematizar conforme sugere Freire $^{79}$, além dos ganhos na relação educador-educandos que deve estar pautada na educação libertadora, há conscientização dos futuros profissionais sobre a realidade que irão intervir, promovendo autonomia profissional e adequação ao novo paradigma em saúde. Respeitando a voz dos discentes no processo, por que ao fazê-lo o docente permite ao discente perceber a necessidade de diálogo, horizontalidade e democracia na relação humana, não apenas na educação ${ }^{84}$, mas para uma postura futura durante sua ação em saúde.

Não há como dissociar este movimento transformador da ação política em prol da consecução verdadeira dos direitos assegurados à todos os cidadãos, e que os mesmos oprimidos aclamados por Freire ${ }^{76-85}$ são os homens e mulheres que mais necessitam destes direitos como realidades, e não como teorias. Os que mais necessitam que enfermeiros, médicos e odontólogos trabalhem por estes e nestes princípios. Que o PSF seja uma realidade, não apenas documental e estrutural, mas que seja realmente estruturante da atenção primária em saúde do Brasil. Que dê certo. Por que a ação profissional deve ser transformadora para ser humanizadora, e não simplesmente técnica e não comprometida com os homens concretos que se referem a que esta ação e a realidade a ela relacionada ${ }^{78}$.

Como poderá o futuro enfermeiro, o futuro médico e o futuro odontólogo o agir horizontalizado, dialogal e político se foi tolhido de perceber horizontalidade, dialogicidade e política em sua formação na medida em que se aprende o que é ser profissional no ambiente universitário? Como primar pela intersetorialidade e a ação social junto a complexidade do paciente, se enquanto educando o educador e a 
estrutura educacional o calou? Há que se ter coerência entre a postura docente e o perfil de egresso que se deseja nos cursos de Enfermagem, Medicina e Odontologia, na perspectiva freireana ${ }^{77}$.

Docentes e discentes ao exercerem ações de construção, criatividade e criticidade sobre o ensino contextualizado na realidade, reafirmam o poder de construir e criticizar a sociedade ${ }^{85}$. Para isso, é necessário abrir o debate e primar pela conscientização, inclusive do docente para que o processo seja genuíno, na medida em que se este não se abre para a mudança, não é possível que conduza de maneira libertadora a educação ${ }^{36}$. Ao contrário, o poder silenciador e dominador da educação tradicional, caracterizada na postura da maioria dos docentes de Enfermagem, Medicina e Odontologia dos cursos investigados, fidedignizam-se aos currículos que tornam o discente um elemento passivo, que se transforma em depósito para os conteúdos narrados nas aulas expositivas, as quais não apenas se revelam recursos pobres em termo didático, mas principalmente revelam um modelo de ensino pautado em autoridades e dominações sociais, deixando adormecidas as potencialidades de criatividade dos futuros enfermeiros, médicos e odontólogos ${ }^{85}$, enquanto que a participação do discente em termos críticos-reflexivos se mostra essencial para a educação libertadora por que implica na tomada de consciência e, em decorrência dessa, da conscientização necessária para a ação crítico-social em saúde ${ }^{76}$. E para a consecução da liberdade, a qual não se trata de algo transmitido ou transferido, mas sim conquistado ${ }^{35}$.

No contexto da presente discussão vale reafirmar que no universo freireano humanizar não tem o sentido apenas de tratar de forma humana, mas sim agir em prol 
dos oprimidos e para o fim da opressão de sua vocação em ser mais, em ser humano. É perceber que o ser humano está inserido em contexto, e este tem dimensões históricas, políticas, econômicas, sociais e culturais ${ }^{36}$. É refletir e agir em nome do fim da coisificação do homem.

O profissional de saúde formado no modelo tradicional, mesmo na perspectiva do PSF, apresenta dificuldade para encarar o propósito de sua ação em saúde pautando sua prática na humanização conforme Freire. Toma a atitude prescritora e de seguir protocolos bem estabelecidos, ficando a margem dos problemas do entorno sócio-cultural dos pacientes, se acomodando com a justificativa de que as coisas são como são e que nada pode fazer ${ }^{36}$, tal qual emergiu nos depoimentos dos acadêmicos do presente estudo. Se o agir do profissional se pautar na busca pela humananização conforme entendida nos pressupostos freireanos ${ }^{35}$, este profissional não mais estarão apenas no mundo, mas se perceberão com o mundo, emergindo destes estados para a consciência de sua inserção na realidade, podendo atuar verdadeiramente em consonância com sua vocação de ser mais, conforme Freire ${ }^{35}$.

Para agir como humano, como homem-enfermeiro, como homem-médico e como homem-odontólogo, frente ao homem-paciente, que lhes é semelhante. 


\section{Capítulo 7}

\section{A CONSTRUÇÃO \\ Algumas considerações finais e o que fica}

Tomar o referencial freireano e partir ruma a tarefa de olhar para a formação do enfermeiro, do médico e do odontólogo, longe de ter se constituído como tarefa fácil, revelou-se complexa. Ainda mais na questão da humanização. Educação e humanização. De profissionais tipicamente tecnicistas e desumanizados, segundo o olhar deste marco teórico.

No entendimento do que foi trazido do Empírico, e trabalhado em estrutura e vivência daqueles que foram submetidos aos processos, o modelo pedagógico universitário mostrou-se implicado na construção das posturas profissionais. Neste caso, na construção de profissionais não humanizadas em termos freireanos. Em futuros enfermeiros, médicos e odontólogos. Mas não em homens-enfermeiros, homens-médicos e homens-odontólogos.

Com relação a como reorientar o processo, na ausência de dialogicidade, criticidade, reflexão e humanização, que delimitou a vivência dos estudantes entrevistados, emergiu o anseio de dialogar, de criticizar, de refletir e de humanizar. Talvez no termo geral, a problematização. Ou no específico, a práxis. 
Sobre os componentes curriculares destas formações, a presença maior de silêncios quanto a conceitos e posturas que pudessem remeter a formação orientada para as disciplinas das Ciências Humanas e Sociais no curso de Odontologia, acrescido ao fato de que, no curso investigado, inexistem disciplinas oriundas desta área, faz pensar na importância destas disciplinas na formação crítico-social do futuro profissional. Faz pensar em como o ensino superior tem o poder de formar profissionais. No entanto, como denunciado pelo que emergiu dos cursos de Enfermagem e Medicina, não basta a existência curricular da disciplina e o trabalho teórico tão somente. Faz-se mister que sejam também problematizadas e transformadas em práxis todas as ações educacionais desta área do conhecimento que, se insiste: foram fundamentais para uma visão mais próxima da perspectiva crítico reflexiva nestes acadêmicos.

A relação docente-discente se mostrou de fundamental importância, e realmente neste imbricamento repousa grande parte dos direcionamentos, tanto para as ações transformadoras, como para futuras investigações sobre o tema. A mesma postura verticalizada, dominadora, bancária, narrativa, vitimizadora do outro, pautada na transmissão da técnica que foi vivenciada pelos acadêmicos, condenada por estes, e presente na maior parte de sua vida estudantil no ensino superior, revelou-se reproduzida na relação profissional-paciente claro, com nuances próprios e característicos de cada profissão. Mas sempre presentes. Eis outro imbricamento que demanda ação transformadora, tanto quanto futuras investigações.

A importância da temática da humanização na saúde foi amplamente apresentada pelos futuros enfermeiros, futuros médicos e futuros odontólogos. No 
entanto, os conceitos e as perspectivas sobre sua atuação profissional frente ao paciente - o outro - apontaram para preconizá-lo da ação técnica, pautada na perspectiva biomédica, e desarticulada com o discurso 'politicamente correto em tempos de humanização', revelam a incoerência entre o que aprenderam teoricamente e o que praticarão na vida vivida. Talvez se tivessem aprendido a teoria na prática e praticado a teoria, em uma perspectiva criativa e humanizadora, o que emergiria seria diferente. Mas, para esta consideração, demandam-se também maiores investigações.

A Saúde Coletiva mostrou-se como área privilegiada, não em termos de retorno financeiro, mas como potencial para transformações. No entanto, silenciaram sobre se, quando atuarem neste campo, se constituirão como agentes transformadores ou se, novamente, apresentam conceitos e teorias, sem articulação com sua prática. E como, se constituírem como tal, promoverão a transformação, dado que aprenderam apenas a técnica de sua profissão. Não aprenderam como articulá-la nem ao menos com outras profissões que dividirão espaço nos Serviços de Saúde. Salvo aquelas que estão sob sua autoridade - enfermeiros e equipe de Enfermagem; médicos e equipe de Enfermagem acrescida do Enfermeiro; odontólogo e equipe de Saúde Bucal. É um pensamento em certa medida radical. Mas os atores envolvidos no processo devem despertar para que não há formação multiprofissional sem exercer na academia a multiprofissionalidade, que não há como aprender a agir além da técnica sem ter agido na academia além da técnica. Caso contrário, mudam-se as aparências do modelo, mas perpetua-se o ensino pautado no modelo bancário e fragmentado. 
A necessidade de reestruturação dos modelos pedagógicos dos cursos investigados foi contundente nas discussões, inclusive encaminhando a reflexão sobre como deverá ser um modelo pautado na articulação entre IES e serviço, não apenas nos estágios, mas de forma integrada em toda a formação do Enfermeiro, do Médico e do Odontólogo.

Foi revelada pertinência do marco teórico freireano como base filosófica à orientação do modelo formativo nas profissões investigadas, na medida em que há coerência entre o SUS e o PSF como se configuram em termos legais (o SUS que se deseja) e os pressupostos de Paulo Freire, uma vez que o universo conceitual freireano tem foco central na humanização e nos aspectos históricos e críticos-sociais.

Também há coerência entre o que se denuncia sobre determinados desafios para a implementação do SUS desejado, principalmente com relação à humanização, e o que o marco teórico apresenta como fator que expropria do homem seu vir-a-ser e, dessa forma, rouba-Ihe a humanidade. Falar em integralidade e intersetorialidade, desafios atuais na consecução efetiva do SUS, é falar destes conceitos.

Com base no exposto, reflete-se que, infelizmente, mesmo com as iniciativas do Governo Federal, do SUS e das IES, e até do reconhecimento por parte dos docentes e discentes envolvidos, ainda há grandes desafios rumo à consecução de uma formação dos enfermeiros, médicos e odontólogos segundo a perspectiva humanizante que é exigida do profissional que atua em PSF, com conformidade com seus princípios, diretrizes e possibilidades.

Chama-se atenção a este termo: possibilidades. Em nenhum outro momento da história do Brasil, como exposto, todos os cidadãos tiveram direito assegurado aos 
serviços de saúde mantidos pelo Estado. E não só isso. Possibilidades. Possibilidades de mudança, de transformação. Uma vez que o PSF e o próprio SUS, como discorrido, podem se constituir como espaço privilegiado de empoderamento, de transformação social e da utopia da cidadania. Caso os atores envolvidos, sejam "molhados, ensopados" neste espírito, parafraseando Freire. Caso se saibam atores, com possibilidades de transformação, já que possuem capacidade para examinar, levantar problemas e para criar soluções.

Há que se caminhar rumo ao homem, em direção à sua humanidade e ao mundo com o qual se encontra. Homem, homens e mundo.

É o que fica: desafios e possibilidades. 


\section{ENCERRAMENTO}

Para encerrar, tomo as palavras de Freire ${ }^{36}$, em 'Pedagogia da Autonomia'

É esta percepção do homem e da mulher como seres 'programados, mas para aprender' e, portanto, para ensinar, para conhecer, para intervir, que me faz entender a prática educativa como um exercício constante em favor da produção e do desenvolvimento da autonomia de educadores e educandos.

Como prática estritamente humana jamais pude entender a educação como uma experiência fria, sem alma, em que os sentimentos e emoções, os desejos, os sonhos devessem ser reprimidos por uma espécie de ditadura reacionista. Nem tampouco jamais compreendi a prática educativa como uma experiência a que faltasse o rigor em que se gera a necessária disciplina intelectual. 


\section{Referências Bibliográficas}

1. Elias PE. Estado e Saúde: os desafios do Brasil contemporâneo. São Paulo em perspectiva. 2004; 18(3):41-6.

2. Campos CEA. O desafio da integralidade segundo as perspectivas da vigilância da saúde e da saúde da família. Ciência \& Saúde Coletiva. 2003; 8(2): 569-84.

3. Albuquerque PC, Stotz EN. A educação popular na atenção básica à saúde no município: em busca da integralidade. Interface - Comunic., Saúde, Educ. 2004; 8(15): 259-74.

4. Stotz EM. Trabalhadores, direito à saúde e ordem social no Brasil. São Paulo Perspec. 2003; 17(1): 25-33.

5. Cohn A; Elias PE. Saúde no Brasil: políticas e organização de serviços. São Paulo: Cortez/Cedec,1998.

6. Silva PLB. Serviços de saúde: o dilema do SUS na nova década. São Paulo em perspectiva. 2003; 17(1): 69-85.

7. Gerschman S. A democracia inconclusa: um estudo da reforma sanitária brasileira. Rio de Janeiro: Editora Fiocruz; 2004.

8. Vasconcelos CM. Paradoxos da mudança no SUS [tese]. Campinas (SP): Departamento de Medicina Preventiva e Social/FCM/UNICAMP; 2005.

9. Campos GWS. O SUS entre a tradição dos Sistemas Nacionais e o modo liberalprivado para organizar o cuidado à saúde Ciência \& Saúde Coletiva. 2007; 12(Sup):1865-1874.

10. Campos CMS, Bataiero MO. Health needs: an analysis of Brazilian scientific literature from 1990 to 2004. Interface - Comunic., Saúde, Educ. 2007; 11(23): 605-18.

11. Aciole GG. On pedagogical dimensions to citizenship building on social control practice. Interface - Comunic., Saúde, Educ. 2007; 11(23):.409-26.

12. Brasil. Ministério da Saúde, Secretaria de Gestão do Trabalho e de Educação na Saúde, Departamento de Educação na Saúde. Política de Educação e Desenvolvimento para o SUS - caminhos para a Educação Permanente em Saúde. Brasília - DF, 2004.

13. Alves VS. A health education model for the Family Health Program: towards comprehensive health care and model reorientation. Interface - Comunic., Saúde, Educ. 2005; 9(16): 39-52. 
14. Simões ALA, Rodrigues FR, Tavares DMS, Rodrigues LR. Humanização na saúde: enfoque na atenção primária. Texto Contexto Enferm. 2007; 16(3): 439-44.

15. Benevides R, Passos E. A humanização como dimensão pública. Cienc \& Saúde Coletiva. 2005; 10(3): 561-71.

16. Schimith MD, Lima MADS. Acolhimento e vínculo em uma equipe do Programa Saúde da Família. Cad Saúde Pública. 2004; 20(6):1487-1494.

17. Brasil. Ministério da Saúde. Saúde da Família: uma estratégia para a reorientação do modelo assistencial. Brasília, 1997.

18. Brasil. Ministério da Saúde. A implantação da Unidade de Saúde da Família. Brasília: Secretaria de Políticas de Saúde/Departamento de Atenção Básica, 2000.

19. Ramos DD, Lima MADS. Acesso e acolhimento aos usuários em uma unidade de saúde de Porto Alegre, Rio Grande do Sul, Brasil. Cad Saúde Pública. 2003; 19(1):27-34.

20. Pinheiro R. As práticas do cotidiano na relação oferta e demanda dos serviços de saúde: um campo de estudo e construção da integralidade. In: Pinheiro R; Mattos RA. (Orgs.) Os sentidos da integralidade na atenção e no cuidado à saúde. Rio de Janeiro: IMS-UERJ, 2001. p.65-112.

21. Pinheiro R. Práticas de saúde e integralidade: as experiências inovadoras na incorporação e desenvolvimento de novas tecnologias assistenciais de atenção aos usuários no SUS. In: Brasil. Ministério da Saúde. Experiências Inovadoras no SUS: relatos de experiências. Brasília, 2002. p.15.

22. Puccini PT, Cecílio LCO. A humanização dos serviços e o direito à saúde. Cad. Saúde Pública, 2004; 20(5):1342-1353

23. Tesser CD. Social medicalization (II): biomedical limits and proposals for primary care clinics. Interface - Comunic., Saúde, Educ. 2006; 10(20): 347-62

24. Gomes MCPA, Pinheiro R. Reception and attachment: integral practices in health care administration in large urban centers. Interface - Comunic., Saúde, Educ. 2005; 9(17): 287-301.

25. Teixeira RR. O acolhimento num serviço de saúde entendido como uma rede de conversações. Pinheiro R, Mattos RA (Orgs.) Construção da integralidade: cotidiano, saberes e práticas em saúde. UERJ/IMS: ABRASCO. 2003. p.89-111.

26. López PP, Lima RC, Mathieu G. La intervención con adolescentes y jóvenes en la prevención y promoción de la salud. Esp. Salud Publica. 2002; 5: 577-84.

27. Brasil. Ministério da Saúde. Experiências Inovadoras no SUS: relatos de experiências. Brasília, 2002

28. Cecílio LCO. As necessidades de saúde como conceito estruturante na luta pela integralidade e eqüidade na atenção em saúde. In: Pinheiro R, Mattos RA (Orgs.) Os sentidos da integralidade na atenção e no cuidado de saúde. Rio de Janeiro: IMS-UERJ/Abrasco, 2001.p.113-126.

29. Malta DC. Buscando novas modelagens em saúde: as contribuições do Projeto Vida e do acolhimento na mudança do processo de trabalho na rede pública de Belo Horizonte, 1993-1996. 2001. Tese (Doutorado) - Faculdade de Medicina Preventiva, Universidade de Campinas, Campinas.

30. Franco TB, Bueno WS, Merhy EE. O acolhimento e os processos de trabalho em saúde: Betim, Minas Gerais, Brasil. Cad Saúde Pública. 1999; 2(15): 345-53. 
31. Merhy EE, 1997. Em busca do tempo perdido: A micropolítica do trabalho vivo em saúde. In: Agir em Saúde: Um Desafio para o Público (E. E. Merhy \& R. Onocko, org.), pp. 71-112, São Paulo: Editora Hucitec.

32. Merhy EE; Campos GWS; Cecílio LCO. Inventando a Mudança na Saúde. São Paulo: Editora Hucitec, 1994

33. Sobrinho, A; Sousa, MF. A tarefa: apagar os sinais vermelhos do PSF. In Sousa, MF (org.) Os sinais vermelhos do PSF. São Paulo (SP): Hucitec, 2002. p.155-70.

34. Markman Neto, L. Políticas de Saúde, Sistema Único de Saúde e a prática do Programa de Saúde da Família num núcleo específico: limites e desafios. 2004. 188 páginas. Dissertação (Mestrado), Faculdade de Medicina de Ribeirão Preto da Universidade de São Paulo. Ribeirão Preto (SP), 2004.

35. Freire P. Pedagogia do oprimido. São Paulo: Paz e Terra. 43a ed. 2005.

36. Freire P. Pedagogia da autonomia. São Paulo: Paz e Terra. 33a ed. 1996.

37. Simões ALA, Rodrigues FR, Tavares DMS, Rodrigues LR. Humanização na saúde: enfoque na atenção primária. Texto Contexto Enferm, Florianópolis, 2007 Jul-Set; 16(3): 439-44.

38. Mota RA, Martins CGM, Veras RM. Papela dos profissionais de saúde na política de humanização hospitalar. Psicologia em Estudo. 2006; 11(2): 323-330.

39. Brasil. Ministério da Saúde. Secretaria de Assistência à Saúde Programa Nacional de Humanização da Assistência Hospitalar/Ministério da Saúde, Secretaria de Assistência à Saúde. - Brasília: Ministério da Saúde, 2001.

40. Santos-Filho SB. Perspectivas da avaliação na Política Nacional de Humanização em Saúde: aspectos conceituais e metodológicos. Ciência \& Saúde Coletiva. 2007; 12(4):999-1010.

41. Brasil, Coordenação Nacional de Saúde Bucal. Projeto SB Brasil. Condições de saúde bucal da população brasileira. Resultados principais. Brasília - DF, 2004 (a).

42. Pessini L, Pereira LL, Zaher VL, Silva MJP. Humanização em saúde: o resgate do ser com competência científica.Mundo Saúde. 2003; 27 (2): 203-5.

43. Bosi MLM. Citizenship, Community Participation, and Health As Seen by Health Care Professionals: A Case Study in Public Health Services. Cad. Saúde Públ. 1994; 4: 446-456.

44. Vaitsman J. Saúde, Cultura e Necessidades. In: Fleury, Sonia (org.). Saúde: Coletiva? Questionando a onipotência do Social. pp.157-73. Rio de Janeiro: Ed.Relume-Dumará, 1992.

45. Caprara, A; Franco, ALS. A Relação paciente/cliente-médico: para uma humanização da prática médica. Cad. Saúde Pública, Rio de Janeiro, 15(3):647-654, jul-set, 1999.

46. Bueno SMV. Educação Preventiva em Sexualidade, DST, AIDS e drogas nas escolas. (Tese de Livre-Docência). Ribeirão Preto, Escola de Enfermagem de Ribeirão Preto da Universidade de São Paulo, 2001.

47. Bueno SMV. Semântica do binômio Saúde-Doença. (Tese de Doutoramento). São Paulo, Faculdade de Enfermagem da Universidade de São Paulo, 1993.

48. Traverso-Yépez $M$, Morais NA. Idéias e concepções permeando a formação profissional entre estudantes das ciências da saúde da UFRN: um olhar da Psicologia Social. Estudos de Psicologia, 9(2), 325-333, 2004. 
49. Traverso-Yépez M. Os discursos e a dimensão simbólica: uma forma de abordagem à psicologia social. Estudos de Psicologia. 1999; 4(1), 39-60.

50. Almeida M, Feuerwerker L, Llanos M. (1999). A educação dos profissionais de saúde na América Latina. Teoría e prática de um movimento de mudança. São Paulo: Hucitec.

51. Byrne N, Rozental M. Tendencias actuales en la educación médica y propuesta de orientação para la educación médica en América Latina. Educación Médica y Salud. 1994; 28(1), 53-93.

52. Kisil M, Chaves M. (1994). Programa UNI. Uma nova iniciativa na educação dos profissionais da saúde. Battle Creek: Fundação W. K. Kellogg.

53. Organização Pan-americana de Saúde (1994). Los cambios de la profesión médica y su influencia sobre la educación médica. Educación Médica y Salud, 28(1), 7-19.

54. Ministério da Saúde. Pró-saúde: programa nacional de reorientação da formação profissional em saúde / Ministério da Saúde, Ministério da Educação. - Brasília : Ministério da Saúde, 2005.

55. Pierantoni, C. R., \& Machado, M. L. (1994). Profesiones de salud: Una formación

56. Ministério da Saúde (BR). Manual de condutas médicas: Programa de Saúde da Família. Brasília (BR): MS; 2002.

57. Ministério da Saúde. Ministério da Educação. A aderência dos cursos de graduação em enfermagem, medicina e odontologia às diretrizes curriculares nacionais / Ministério da Saúde, Ministério da Educação. - Brasília : Ministério da Saúde, 2006.

58. Campos FE, Pierantoni CR, Haddad AE, Viana ALA, Faria RMB. Os desafios atuais para a educação permanente no SUS. Cad RH Saúde. 2006; 3(1): 39-51.

59. Campos GWS. Políticas de formação de pessoal para o SUS: reflexões fragmentadas. Cad RH Saúde. 2006; 3(1): 52-56

60. Scherer ZAP, Scherer EA. Reflections on nursing teaching in the post-modernity era and the metaphor of a theory-practice gap. Rev Latino-am Enfermagem. 2007; 15(3):498-501.

61. Pinto JBT, Pepe AM. Nursing education: contradictions and challenges of pedagogical practice. Rev Latino-am Enfermagem. 2007; 15(1):120-6.

62. Freitas DMV, Fávaro N, Scatena MCM. O ensino de graduação na escola de enfermagem de Ribeirão Preto da Universidade de São Paulo: Suas perspectivas. Rev. Latino-am. Enfermagem. 1993; 1(spec): 25-34.

63. Chaves EA. O desempenho de papéis sociais numa relação de ensino-aprendizado. Rev Latino-am. Enfermagem. 1993; 1(spec): 35-42.

64. Silva AL, Camillo SO. A educação em enfermagem à luz do paradigma da complexidade. Rev Esc Enferm USP. 2007; 41(3):403-10.

65. Koifman $\mathrm{L}$. The biomedical model and the reformulation of the medical curriculum of Universidade Federal Fluminense. Hist Ciênc Saúde. 2001; 8(1): 48-70.

66. Coelho BM, Zanetti MV, Lotufo-Neto F. Residência em psiquiatria no Brasil: análise crítica. Rev Psiquiatr RS. 2005;27(1):13-22.

67. Blank D. A propósito de cenários e atores: de que peça estamos falando? Uma luz diferente sobre o cenário da prática dos médicos em formação. Rev Bras Ens Med. 2006; 30(1): 27-31. 
68. Noronha Filho G, Resende JB, Lemme AC, Ney Júnior G, Frossard A. Formação médica e integração de atividades. Rev Saúde Pub. 1995; 29(3): 215-20

69. Pinheiro AS, Moreira MIBG, Freitas MMA. Medical teaching and health promotion in day nursery institution. Rev Ass Med Brasil. 2001; 47(3): 320-4.

70. Cyrino EG; Rizzato ABP. Contribuição à mudança curricular na graduação da Faculdade de Mecina de Botucatu. Rev Bras Saúde Matern Infant. 2004; 4(1): 5969.

71. Pontes $A L$, Rego S, Silva Júnior AG. Saber e prática docente na transformação do ensino médico. Rev Bras Educ Med. 2006; 30(2): 66-75

72. Nuto SAS, Noro LRA, Cavalsina PG, Costa IC, Oliveira AGRC. O processo ensinoaprendizagem e suas conseqüências na relação professor-aluno-paciente. Ciência \& Saúde Coletiva. 2006; 11(1):89-96.

73. Freitas SFT, Kovaleski DF, Boing AF. Desenvolvimento moral em formandos de um curso de odontologia: uma avaliação construtivista. Ciência \& Saúde Coletiva. 2005. 10(2): 435-62.

74. Matos PES, Tomita NE. A inserção da saúde bucal no Programa Saúde da Família: da universidade aos pólos de capacitação. Cad Saúde Pública. 2004; 20(6):15381544.

75. Secco LG, Pereira MLT.Formadores em odontologia: profissionalização docente e desafios político-estruturais. Ciência \& Saúde Coletiva. 2004; 9(1):113-120.

76. Araújo ME. Palavras e silêncios na educação superior em odontologia. Ciência \& Saúde Coletiva. 2006; 11(1):179-182.

77. Moretti-Pires RO. A mercantilização da saúde: o trabalho dos cirurgiões dentistas em um contexto de mudanças - estudo com cirurgiões dentistas assalariados do município de Ribeirão Preto (SP). (Dissertação de Mestrado) Faculdade de Medicina de Ribeirão Preto, 2005.

78. Gadotti M. Prefácio. In: Freire P. Educação e mudança. São Paulo: Paz e Terra. 28ạ ed. 1979: pp. 9-25.

79. Freire P. Educação como prática da liberdade. Rio de Janeiro: Paz e Terra. 4ạ ed. 1974.

80. Freire P. Ação cultural para a liberdade e outros escritos. São Paulo: Paz e Terra. 10 a ed. 2007.

81. Freire P. Educação e mudança. São Paulo: Paz e Terra. 28a ed. 1979.

82. Freire P. Concientização: teoria e prática da liberdade - uma introdução ao pensamento de Paulo Freire. São Paulo: Centauro. 3a ed. 2001.

83. Freire P. Pedagogia da Esperança: um reencontro com a pedagogia do oprimido. Rio de Janeiro: Paz e Terra. 1992.

84. Freire P. Pedagogia da indignação: cartas pedagógicas e outros escritos. São Paulo: Editora UNESP. 2000.

85. Freire P. Pedagogia dos sonhos possíveis. São Paulo: Editora UNESP, 2001.

86. Freire P. À sombra desta mangueira. São Paulo: Olho D'água. 2006.

87. Freire P. Professora sim tia não - cartas a quem ousa ensinar. São Paulo: Olho D’Água. 16a ed. 2006.

88. Ira S, Freire P. Medo e ousadia - o cotidiano do professor. Rio de Janeiro: Paz e Terra. $10^{\text {a }}$ ed. 1986. 
89. Gadotti M. Concepção dialética da educação. São Paulo: Cortez, 2003.

90. Leopardi MT. Metodologia da pesquisa na saúde. 2.ed. Florianópolis: UFSC/Pósgraduação em Enfermagem; 2002.

91. Haguette, TMF. Metodologias qualitativas na sociologia. Petrópolis, 8a edição, editora Vozes, 2001.

92. Minayo MCS. O desafio do conhecimento: pesquisa qualitativa em saúde. 6a edição, HUBITEC-ABRASCO, São Paulo - Rio de Janeiro, 1999.

93. Crotty $M$. The foundations of Social Research - meaning d perspective in the research process. London, Sage Publications, 2003.

94. Berg, B.L. Qualitative research methods for the social sciences. Long Beach Califórnia, Ed.Pearson, 2004.

95. Morgan D. Focus Group as qualitative research. 2nd Ed. Sage Publications, 1997.

96. Beck CLC; Gonzales RMB; Leopardi MT. Técnicas e procedimentos de pesquisa qualitativa. In: Leopardi, M.T (org.). Metodologia da pesquisa na saúde. 2.ed. Florianópolis: UFSC/Pós-graduação em Enfermagem; 2002, pp.223-44.

97. Almeida A. Hidrovia Tocantins-Araguaia: a importância e impactos econômicos, sociais e ambientais segundo a percepção dos agentes econômicos locais. (Tese de doutoramento) ESALQ/USP, Piracicaba (SP), 2004, 155p.: il.

98. Scharader A. Introdução à pesquisa social empírica. Porto Alegre, Ed.Globo, 1974.

99. Phillips BS. Pesquisa social. Rio de Janeiro, Agir, 1974.

100.Gil AC. Métodos e técnicas de pesquisa social. 5.ed. São Paulo: Atlas, 1999.

101.Gil AC. Como elaborar projetos de pesquisa. 4.ed. São Paulo: Atlas, 2002.

102. Loizos P. Vídeo, filme e fotografias como documentos de pesquisa. In: Bauer MW; Gaskell G (org.). Pesquisa qualitativa com texto, imagem e som: um manual prático. Petrópolis: Vozes, 2002.

103.Mann P. Métodos de investigação sociológica. 3.ed. Rio de Janeiro: Zahar, 1975.

104. Moreira SV. Análise documental como método e como técnica. In: Duarte J; Barros

105.Ludke M; André MEAD. Pesquisa em Educação: abordagens qualitativa. 9ạ edição. São Paulo: EPU; 2005.

106. Coreil J. Group interview methods in Community Health Research. Medical antropology, 16: 193-210, 1995.

107.Rabiee F. Focus-group interviews and data analysis. Proceedings of the Nutrition Society (2004), 63, 655-660

108.Grudens-schuck N; Allen BL; Larson K. Focus Group Fundamentals. lowa State University, University Extension, 2004.

109. Krueger RA. Focus Groups: A Practical Guide for Applied Research. Thousand Oaks, CA: Sage Publications, 1994.

110.Rosa RB, Maffacciolli R, Nauderer TM, Pedro ENR. A educação em saúde no currículo de um curso de enfermagem: o aprender para educação. Rev Gaucha Enferm. 2006, 27(2):185-92

111.Denzin NK. The research act. Chicago: Aldine Publishing Company, 1973.

112.Samaja J. La combinacion de métodos: pasos para uma comprension dialéctica del trabajo interdisciplinário. Educ Med Social. 1992, 26(1):4-34.

113. Minayo MCS. Avaliação por triangulação de métodos. Rio de Janeiro: Editora Fiocruz, 2004. 
114.Minayo MCS, Deslandes SF (org). Caminhos do pensamento: epistemologia e método. Rio de Janeiro: Editora Fiocruz, 2002.

115.Schraiber LB, Peduzzi M, Sala A, Nemes MIB, Castanhera ERL, Kon R. Planejamento, gestão e avaliação em saúde: identificando problemas. Cienc Saúde Col. 1999, 4(2): 221-242.

116. Heidemann ITSB. A promoção de saúde e a concepção dialógica de Freire: possibilidades de sua inserção e limites no processo de trabalho das equipes de Saúde da Família. (Tese) Escola de Enfermagem de Ribeirão Preto da Universidade de São Paulo, 2006.

117. Figueiredo JS. Desafios e perspectivas em atividades educativas de promoção de saúde de um grupo de portadores de hipertensão arterial, sob o paradigma da interdisciplinaridade. (Tese) Escola de Enfermagem de Ribeirão Preto da Universidade de São Paulo, 2006.

118.Santos VC. A relação trabalho-saúde dos enfermeiro do PSF da Região de Vila Prudente-Sapopema: um estudo de caso. (Dissertação) Escola de Enfermagem da Universidade de São Paulo, 2007.

119.Labonte R, Feather J, Hills M. A story/dialogue method for health promotion knowledge development and evaluation. Health Edu Res. 1999, 14:39-50.

120.Dubeux LS, Cezarin G, Figueiró AC, Bezerra LCA, Barros M, Salvi A, Oliveira D, Sampaio G. Formação de avaliadores na modalidade educação a distância: necessidade transformada em realidade. Rev Bras Saúde Matern Infant. 2007, 7(Spec.1): S47-S52.

121.Wynne N, Brand S, Smith R. Incomplete holism in pre-registration nurse education: the position of the biological sciences. J Advanc Nurs. 1997, 26: 470-474.

122.Dulmen S; Sluijs E; Dijk L; Ridder D; Heerdik R; Bensing J. Patient adherence to medical treatment: a rewiew of rewiews. BMC Health Services Research 2007, 55 (7): 1-13.

123.Gattás MLB. Interdisciplinaridade em cursos de graduação na área da saúde da Universidade de Uberaba - UNIUBE. Escola de Enfermagem de Ribeirão Preto, 2005.

124. Ribeiro MILC. A teoria, a percepção e a prática do relacionamento interpessoal. Escola de Enfermagem de Ribeirão Preto da Universidade de São Paulo, 2005.

125.Domingues TAM. Os valores das enfermeiras na intenção do agir ético. (Tese) Escola de Enfermagem da Universidade de São Paulo, 2004.

126.Budó MLD, Nicolini D, Resta DG, Buttenbender E, Pippi MC, Ressel LB. A cultura permeando os sentimentos e as relações frente à dor. Rev Esc Enferm USP. 2007, 41(1): 36-43.

127.Boehs AE, Monticelli M, Wosny AM, Heidemann IVS, Grisotti M. A interface necessária entre a enfermagem, educação em saúde e o conceito de cultura. Texto Cont Enf. 2007, 16(2): 307-14.

128. Machado MH. Médicos, organizações de saúde e ética. Rev Bras Educ Med. 2000, 24(1): 68-71.

129.Carmelo SHH. Riscos psicossociais relacionados ao estresse no trabalho das equipes de saúde da família e estratégias de gerenciamento. (Tese) Escola de Enfermagem de Ribeirão Preto da Universidade de São Paulo, 2006. 
130. Costa ASSM. A construção do saber da enfermeira na equipe interdisciplinar de serviço de atenção psicossocial. (Tese) Escola de Enfermagem da Universidade de São Paulo, 2005.

131.Bernardes EH. Princípios do Sistema Único de Saúde: concepção dos enfermeiros do Programa de Saúde da Família, de uma cidade do Estado de Minas Gerais. (Dissertação) Escola de Enfermagem de Ribeirão Preto da Universidade de São Paulo, 2005.

132.Banda MMZ. Compreensão típico ideal da prática profissional do enfermeiro em hospitais públicos. (Tese) Escola de Enfermagem de Ribeirão Preto, 2004.

133.Avarenga LMCA. A prática médica no programa de saúde da família e sua contribuição para mudança no modelo tecnicoassistencial em saúde: limites e possibilidades. (Dissertação) Faculdade de Saúde Pública da Universidade de São Paulo, 2005.

134.Taquette, SR; Schramm, SRFR; Soares, LL; Carvalho, SV. Situações eticamente conflituosas vivenciadas por estudantes de medicina. Rev Assoc Med Bras 2005; 51(1): 23-8.

135.Silva MG, Ruffino MC. Comportamento docente no ensino de graduação em enfermagem: a percepção dos alunos. Rev.latino-am.enfermagem. 1999, 7(4): 4555

136. Mello, ACF. Mercado de trabalho, política de saúde bucal e formação profissional: o que pensam estudantes de odontologia. 2004. 146 páginas. Dissertação (Mestrado), Universidade Federal do Rio de Janeiro. Rio de Janeiro (RJ), 2004.

137.Werneck, MAF. A Saúde Bucal no SUS: uma perspectiva de mudança. 1994. Tese (Doutorado) - Universidade Federal Fluminense, Niterói, 1994.

138.Portillo, JAC. A inserção da odontologia no S.U.S. - avanços e dificuldades. 1998.

139.Araújo YP, Dimenstein M. Estrutura e organização do trabalho do cirurgiãodentista no PSF de municípios do Rio Grande do Norte. Cien Saúde Coletiva. 2006, 11(1): 219-227.

140.Esperidião E. Holismo só na teoria: a trama dos sentimento do acadêmico de enfermagem sobre sua formação. (Dissertação) Escola de Enfermagem de Ribeirão Preto, 2001.

141.Leonardi J. O caminho noético: o canto e as danças circulares como veículo da saúde existencial no cuidar. (Dissertação) Escola de Enfermagem de Ribeirão Preto da Universidade de São Paulo, 2007.

142. Chirelli MQ. O processo de formação do enfermeiro crítico-reflexivo na visão dos alunos do curso de enfermagem da FAMEMA. (Tese) Escola de Enfermagem de Ribeirão Preto da Universidade de São Paulo, 2002.

143.Esperidião E. Repensando a formação do enfermeiro: o processo de conscientização crítica e práticas docentes à luz do referencial ético-humanista. (Tese) Escola de Enfermagem de Ribeirão Preto, 2005.

144. Meira MDD. Avaliação da formação do enfermeiro: percepção de egressos de um curso de graduação em enfermagem. (Dissertação) Escola de Enfermagem da Universidade de São Paulo, 2007.

145. Campos MAF. Percepção e avaliação dos alunos do curso de medicina de uma escola médica pública sobre a importância do estágio em saúde da família na sua 
formação. (Dissertação) Faculdade de Medicina de Ribeirão Preto da Universidade de São Paulo, 2006.

146. Mezzaroba L. Concepções de avaliação de professores e alunos de farmácia e bioquímica da Universidade Estadual de Londrina, Paraná. Rev Bras Educ Med. 2000, 24(3): 53-61.

147. Colares MFA, Troncon LEA, Figueiredo JFC, Cianflone ARL, Rodrigues MLV, Piccinato CV, Peres LC, Coleta JAD. Construção de um instrumento para avaliação de atitudes de estudantes de medicina frente a aspectos relevantes da prática médica. Ver Bras Educ Med. 2002, 26(3): 194-203.

148.Sordi MRL, Bagnato MHS. Subsídeos para uma formação profissional críticoreflexiva na área da saúde: o desafio da virada do século. Rev Lat-am Enf. 1998, 6(2): 83-8.

149.Batista SHS. A interdisciplinaridade no ensino médico. Rev Bras Educ Med. 2006, 30(1): 39-46.

150.Teixeira MAP, Gomes WB. Decisão de carreira entre estudantes em fim de curso universitário. Psi teor prat. 2005, 21(3): 327-334.

151. Marco MA. Do modelo biomédico ao modelo biopsicossocial: um projeto de educação permanente. Rev Bras Educ Med. 2006, 30(1):60-72.

152. Yazbek DCM, Azevedo LL, Siqueira MRL, Menezes VM. Novos rumos para a educação médica. Rev Bras Educ Med. 2000, 24(2): 26-8.

153.Ronzani TM. A reforma curricular nos cursos de saúde: qual o papel das crenças? Rev Bras Educ Med. 2007, 31(1): 38-43.

154. Moretto R, Mansur OC. Ser professor. Rev Bras Educ Med. 2000, 24(2): 5-8.

155.Mann K, Gordon J, MacLeod A. Reflection and reflective practice in health professions education: a systematic review. Adv in Health Sci Edu. 2007, DOI 10.1007/s10459-007-9090-2

156.Simovska V. Student participation: a democratic education perspective experience from the health-promoting schools in Macedonia. Health Edu Res. 2004, 19(2): 198-207.

157.Silva EC. Educação à distância: ambientes digitais para o processo ensinoaprendizagem em enfermagem psiquiátrica. (Tese) Escola de Enfermagem de Ribeirão Preto, 2007.

158.Takayanagui AMM. Trabalhadores de saúde e meio ambiente: ação educativa do enfermeiro na conscientização para o gerenciamento de resíduos sólidos. (Tese) Escola de Enfermagem de Ribeirão Preto da Universidade de São Paulo, 1993.

159.Pauli MC, Bousso RS. Crenças que permeiam a humanização da assistência em unidade de terapia intensiva pediátrica. Rev Latino-Am Enfermagem 2003 maiojunho; 11(3):280-6.

160.Agostini R. O conflito como fenômeno organizacional: identificação e abordagem na equipe de enfermagem. (Dissertação) Escola de Enfermagem de Ribeirão Preto da Universidade de São Paulo, 2005.

161.Araújo RRDF. A educação conscientizadora na prática do enfermeiro em hanseníase. (Tese) Escola de Enfermagem de Ribeirão Preto/Escola de Enfermagem, 2005. 
162.Almeida DV. O ensino da humanização nos currículos de graduação em enfermagem. (Dissertação) Escola de Enfermagem da Universidade de São Paulo, 2007.

163.Gabrielli JMW. Formação do enfermeiro: buracos negros e pontos de luz. (Tese) Escola de Enfermagem de Ribeirão Preto da Universidade de São Paulo, 2004.

164.Silva EC. Educação à distância: ambientes digitais para o processo ensinoaprendizagem em enfermagem psiquiátrica. (tese) Escola de Enfermagem de Ribeirão Preto, 2007.

165.Ito EE. O estágio curricular segundo a percepção dos enfermeiros assistenciais de um hospital de ensino. (Dissertação) Escola de Enfermagem da Universidade de São Paulo, 2005.

166. Reinaldo MAS. Gerenciamento de casos como estratégias de trabalho para enfermeira psiquiátrica comunitária. (Tese) Escola de Enfermagem de Ribeirão Preto da Universidade de São Paulo, 2005.

167.Pires RP. Formação de competência na interface estágio extracurricular e início de atuação profissional como enfermeiro. (Dissertação) Escola de Enfermagem da Universidade de São Paulo, 2006.

168. Frazili RTV. O enfermeiro e as famílias: necessidades de aperfeiçoamento do enfermeiro nas práticas com famílias no Programa de Saúde da Família. (Dissertação) Escola de Enfermagem da Universidade de São Paulo, 2006.

169.Saar SRC. Especificidade do enfermeiro: uma visão multidisciplinar. (Tese) Escola de Enfermagem de Ribeirão Preto da Universidade de São Paulo, 2005.

170.Santos LHP. Estratégias e avaliação no processo ensino-aprendizagem e a postura do professor na educação profissional em enfermagem. (Tese) Escola de Enfermagem de Ribeirão Preto da Universidade de São Paulo, 2005.

171.Scherer ZAP. Grupoterapia e enfermagem: o estudante e a transição teóricoprática. (Tese) Escola de Enfermagem de Ribeirão Preto da Universidade de São Paulo, 2005.

172. Resck ZMR. A formação e a prática gerencial do enfermeiro para o trabalho em saúde: delineando caminhos para a práxis transformadora. (Tese) Escola de Enfermagem de Ribeirão Preto da Universidade de São Paulo, 2006.

173. Bagnato MHS, Rodrigues RM. Diretrizes curriculares da graduação de enfermagem: pensando contextos, mudanças e perspectivas. Rev Bras Enf. 2007, 60(5): 507-12.

174. Wyatt DE. The impact of oncology education on practice - a literature rewiew. Europ J Onco Nurs. 2007, 11: 255-61.

175.Spitzer A, Perrenoud B. Reforms in nursing education across western europe: implementation process and current status. J Prof Nurs. 2006, 22:162-71.

176. Friedel JM, Treagust DF. Learning Bioscience in nursing education: perceptions of the intended and the prescribed curriculum. Learning in Health and Social Care. 2005, 4(4): 203-16

177.Rodrigues MTR, Mendes JAC Sobrinho. Enfermeiro professor: um diálogo com a formação pedagógica. Rev Bras Enf. 2007, 60(4): 456-9. 
178.Troncon LEA, Colares MFA, Figueiredo JFC, Cianflone ARL, Rodrigues MLV, Piccinato CV, Peres LC. Atitudes de Graduandos de Medicina em relação à aspectos relevantes da prática médica. Rev Bras Educ Med. 2003, 27(1): 20-8.

179. Troncon LEA, Colares MFA, Figueiredo JFC, Cianflone ARL, Rodrigues MLV, Piccinato CV, Peres LC. Avaliação de uma reestruturação curricular na faculdade de medicina de Ribeirão Preto: influência sobre o desempenho dos graduandos. Rev Bras Educ Med. 2004, 28(2): 145-155

180.Gontijo LPT. Construindo as competências do cirurgião-dentista na atenção primária em saúde. (Tese) Escola de Enfermagem de Ribeirão Preto da Universidade de São Paulo, 2007.

181.Cruvinel LMCM. A atual reforma do ensino superior brasileiro e os desafios para o docente universitário: subsídeos para a odontologia. (Dissertação) Faculdade de Odontologia da Universidade de São Paulo, 2007.

182. Moretti-Pires RO, Lopes F Neto, Lopes JB, Bueno SMV. O conhecimento dos Agentes Comunitários de Saúde sobre Saúde Bucal: uma perspectiva sobre deficiências em educação em saúde no PSF. Cienc Cuidado Saúde. No prelo.

183. Brasil. Conselho Nacional de Educação Superior. Institui Diretrizes Curriculares Nacionais do Curso de Graduação em Enfermagem. Resolução CNE/CES 3/2001. Diário Oficial da União, Brasília, 9 de Novembro de 2001. Seção 1, p. 37.

184.Brasil. Conselho Nacional de Educação Superior. Resolução CNE/CES 4/2001. Institui Diretrizes Curriculares Nacionais do Curso de Graduação em Medicina. Diário Oficial da União, Brasília, 9 de novembro de 2001. Seção 1, p. 38.

185. Brasil. Conselho Nacional de Educação Superior. Institui Diretrizes Curriculares Nacionais do Curso de Graduação em Odontologia. Resolução CNE/CES 3/2002. Diário Oficial da União, Brasília, 4 de março de 2002. Seção 1, p. 10

186. Instituto Nacional de Estudos e Pesquisas Educacionais Anísio Teixeira (INEP). A trajetória dos cursos de graduação na área da saúde: 1991-2004. Brasília: INEP, 2006.

187.Dellasega C, Millone-Nuzzo P, Curci KM, Ballard JO, Kirch DG. The humanities interface of nursing and medicine. J Profl Nurs. 2007, 23(3): 174-179.

188. Brasil. Ministério da Saúde. Diretrizes operacionais dos Pactos pela Vida, em defesa do SUS e de Gestão. Brasília: Ministério da Saúde, 2006a, 76p.

189. Brasil. Ministério da Saúde. Política nacional de atenção básica. Brasília: Ministério da Saúde, 2006b, 60p.

190.Bueno SMV. Educação preventiva em sexualidade, DST-AIDS e drogas nas escolas - pesquisação e o compromisso social. (Tese de Livre-Docência) Escola de Enfermagem de Ribeirão Preto da Universidade de São Paulo, 2001.

191. Moretti-Pires RO, Bueno SMV. O uso da pedagogia da problematização como modelo pedagógico para curso de Saúde da Família à alunos de Odontologia. Cienc Cuidado Saúde. 2005, 4(3): 294-300.

192.Zanotto MAC, Rose TMS. Problematizar a própria realidade: análise de uma experiência de formação contínua. Edu Pesq. 2003, 29(1): 45-54.

193.Zanotto MAC. A formação contínua como possibilidade do aprimoramento da ação de problematizar: análise de uma proposta voltada para professores 
atuantes em Educação Especial. 2002. (Tese de Doutorado) Universidade Federal de São Carlos, 2002.

194. Carvalho SR, Garcia RA, Rocha DC. Teaching Collective Health at the medical school of the Unicamp: innovative experiences at the basic health units. Interface - Comunic Saúde Educ. 2006, 10(2): 457-72.

195.Batista N, Batista SH, Goldenberg P, Seiffert O, Sonzogno MC. O enfoque problematizador na formação dos profissionais de saúde. Rev Saúde Pub. 2005, 39(2): 231-7.

196.Vasconcellos CS. Planejamento: projeto de ensino-aprendizagem e projeto político-pedagógico. São Paulo: Liberdade, 2000.

197.Fleuri RM. Educar para quê? São Paulo: Cortez Editora, 2001.

198.Sacristán JG, Gómez AIP. Compreender e transformar o ensino. Porto Alegre: Artmed Editora, 1998.

199.Saul AM. Avaliação emancipatória. São Paulo: Cortez, 2000.

200.McLaren P. A vida nas escolas. Porto Alegre: Artes Médicas, 1997.

201.Perrenoud P. A prática reflexiva no ofício de professor. Porto Alegre: Artmed Editora, 2002.

202.Romão JE. Pedagogia dialógica. São Paulo: Cortez, 2007.

203.Padilha PR. Planejamento dialógico. São Paulo: Cortez, 2007.

204.Padilha PR. Currículo intertranscultural. São Paulo: Cortez, 2004.

205.Torres CA. Teoria crítica e sociologia política da educação. São Paulo: Cortez, 2003.

206.Imbernón F. Formação docente e profissional: formarse para a mudança e a incerteza. São Paulo: Cortez, 2004.

207. Rozendo CA, Casagrande LDR, Schneider JF, Pardini JC. Uma análise das práticas docentes de professores universitários da área de saúde. Rev.latinoam.enfermagem, 1999, 7(2): 15-23.

208. Reis DC. Educação em saúde: aspectos históricos e conceituais. In: Gazzinelli MF, Reis DC, Marques RC (org). Educação em Saúde: teoria, método e imaginação. Belo Horizonte: Editora UFMG, 2006, pp.19-24.

209.Giroux H. A escola crítica e a política cultural. São Paulo: Cortez, 1987. 


\section{anexos}


anexo I: Termo de Consentimento Livre e Esclarecido

\section{CONVITE}

Venho através deste convida-lo a dar sua contribuição para minha pesquisa de Doutoramento, a qual se intitula "A HUMANIZAÇÃO E A CONCEPÇÃO PEDAGÓGICA CRÍTICO-SOCIAL NO ENSINO DE ENFERMAGEM, MEDICINA E ODONTOLOGIA NO ESTADO DO AMAZONAS", que se destina entender como é o modelo pedagógico que foi utilizado em seu curso de Graduação, no que se refere a formação de um profissional de saúde humanizado. Para isso serão realizadas entrevistas em grupos (o que é chamado de grupo focal) e posteriormente entrevistas individuais com aqueles que participarem das primeiras e desejarem contribuir nesta segunda fase. Todas as entrevistas serão gravadas, e o material transcrito. Destes, serão retiradas apenas as falas que forem pertinentes à Tese, não havendo qualquer forma de identificação de quem participou desta pesquisa. Ressalto que esta pesquisa, como o titulo sugere, estará sendo conduzida com alunos nos últimos períodos dos cursos de Enfermagem, Medicina e Odontologia da Universidade Federal do Amazonas. Em caso de dúvidas, estou aberto a questionamentos.

Grato,

Prof ${ }^{\circ}$ Rodrigo

\section{Declaração}

Declaro que foi esclarecido dos objetivos da presente pesquisa e estou em acordo com os mesmos. Afirmo que fui informado sobre a liberdade de recusar ou retirar o consentimento, a qualquer momento, sem penalizações de qualquer natureza, e que, lido e entendido o termo, assino-o junto ao pesquisador, em duas cópias, uma das quais ficará em minha posse e a outra com ele.

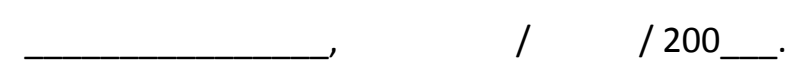

Nome:

RG..
Rodrigo Otávio Moretti-Pires

Professor Assistente MS-B

Universidade Federal do Amazonas

SIAPE 1547277

Rua Genival Guerra, 250 - Coari (AM)

Fone: (97) 3561.2363 


\section{anexo II: Parecer do Comitê de Ética em Pesquisa com Seres Humanos}

\section{PARECER DO COMITÊ DE ÉTICA EM PESQUISA}

O Comitê de Ética em Pesquisa da Universidade Federal do Amazonas aprovou, em reunião ordinária realizada nesta data, por unanimidade de votos, o Projeto de Pesquisa protocolado no CEP/UFAM com o número 230/2006, intitulado: “A Humanização e a Concepção Pedagógica Crítico-Social no Ensino de Enfermagem, Medicina e Odontologia no Estado do Amazonas." tendo como Pesquisadora Responsável Rodrigo Otávio Moretti Pires.

Sala de Reunião da Escola de Enfermagem de Manaus - EEM da Universidade Federal do Amazonas, em Manaus/Amazonas, 28 de dezembro de 2006.

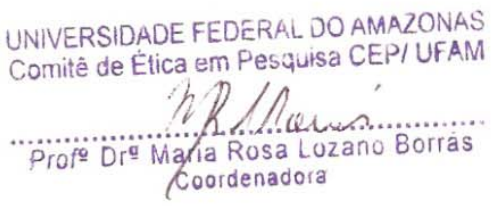

Rua Teresina, 495 - Adrianópolis - Cep. 69.057-070 - Manaus/AM - Fone: (92) 622-2724 r. 32 E-mail: cep@ufam.edu.br 
Anexo III: Matriz Curricular do Curso de Enfermagem para a turma do último período cursado no primeiro semestre de 2007.

Curso: EM01 - Enfermagem

Grau do Curso: Enfermeiro
Turno: Diurno
Versão: 2004/1

Situação: Corrente

\section{PERÍ OdO CÓD.}

CARGA HORÁRI A

CRÉD.TEOR.PRAT.TOTAL PRÉ-REQUISITO

\section{OPTATIVAS}

TOTAL

EEF025 BIOÉTICA

EEF038 ENF. EM ATENÇÃO À SAÚDE DO IDOSO

EEF021 ENF. EM ATENÇÃO À SAÚDE DO TRABALHADOR

EEF040 ENFERMAGEM EM ATENÇÃO À SAÚDE DA FAMÍLIA

FEF008 RELACOES INTERPESSOAIS

APC001 SALDO DE CRÉDITOS (Aprov. e Equivalencia)

IHS327 SAUDE E SOCIEDADE

EEF045 SISTEMATIZAÇÃO DA ASSIST. DE ENFERMAGEM

EMC019 SUPORTE BÁSICO DE VIDA PARA O ENFERMEIRO

IEE006 BIOESTATISTICA

IBM309 CITOLOGIA E HISTOGENESE

EEF032 DIDÁTICA APLICADA À SAÚDE

IBM111 FUNDAMENTOS DE ANATOMIA

EEF001 HISTORIA DA ENFERMAGEM

EEF022 MET. EST. DA PESQUISA APLICADA À ENFERMAGEM

FEF011 PSICOLOGIA GERAL I

IEQ601 QUIMICA GERAL

IHF009 ANTROPOLOGIA FILOSOFICA

IBF022 BIOQUIMICA

IBM030 EMBRIOLOGIA

EEF030 ÉTICA E LEGISLAÇÃO DE ENFERMAGEM

IBF008 FISIOLOGIA

IBB001 GENETICA BASICA

FEF012 PSICOLOGIA DA EDUCACAO I

IHS011 SOCIOLOGIA I

IBF016 FARMACOLOGIA

IBP029 IMUNOLOGIA

IBP029 IMUNOLOGIA

IBP019 MICROBIOLOGIA

IBP016 PARASITOLOGIA BASICA

FSL003 PROCESSOS PATOLOGICOS GERAIS

FSL003 PROCESSOS PATOLOGICOS GERAIS

EEF035 SEMIOLOGIA E SEMIOTÉCNICA

EEF035 SEMIOLOGIA E SEMIOTÉCNICA

EEF035 SEMIOLOGIA E SEMIOTÉCNICA

EMC021 ENFERMAGEM CIRÚRGICA (PRÉ-TRANS-PÓS-OPERAT.

EMC021 ENFERMAGEM CIRÚRGICA (PRÉ-TRANS-PÓS-OPERAT.

EMC017 ENFERMAGEM EM DOENCAS TRANSMISSIVEIS

EMC017 ENFERMAGEM EM DOENCAS TRANSMISSIVEIS

EMC017 ENFERMAGEM EM DOENCAS TRANSMISSIVEIS

EMC020 ENFERMAGEM MÉDICA

EMC020 ENFERMAGEM MÉDICA

FSC018 EPIDEMIOLOGIA I

FST025 NUTRICAO APLICADA A ENFERMAGEM

EMC022 ENFERMAGEM DE SAÚDE MENTAL E PSIQUIATRIA

EMC022 ENFERMAGEM DE SAÚDE MENTAL E PSIQUIATRIA

EMS042 ENFERMAGEM NA ATENÇÃO INT. À SAÚDE DA CRIANÇA

EMS042 ENFERMAGEM NA ATENÇÃO INT. À SAÚDE DA CRIANÇA

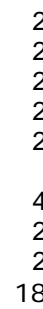

230

230

$2 \quad 30$

$4 \quad 60$

$2 \quad 15$

$2 \quad 15$

18225

30

30

45
30

30

30

60

$30 \quad 45$

$30 \quad 45$

$90 \quad 315$

$460 \quad 60$

IEQ601

IBM309

IBM111

IBM309

FEF011

IBF022 BLOCO 1

IBF008

IBM111

IBF008

IBF022

IBM309

IBM309

IBM111

IBM309

IBM309

IBF022

IBF008

EEF001

EEF022

IBF008

EEF030

IBF022

FSL003

IBF016

EEF035

IBP016

IBF016

IBP029

EEF035

IBP019

IBF016

IBP029

IEE006

IBF022

IBF008

FEF012

IBF016

EEF035

FEF012

EMC017

EMC020 


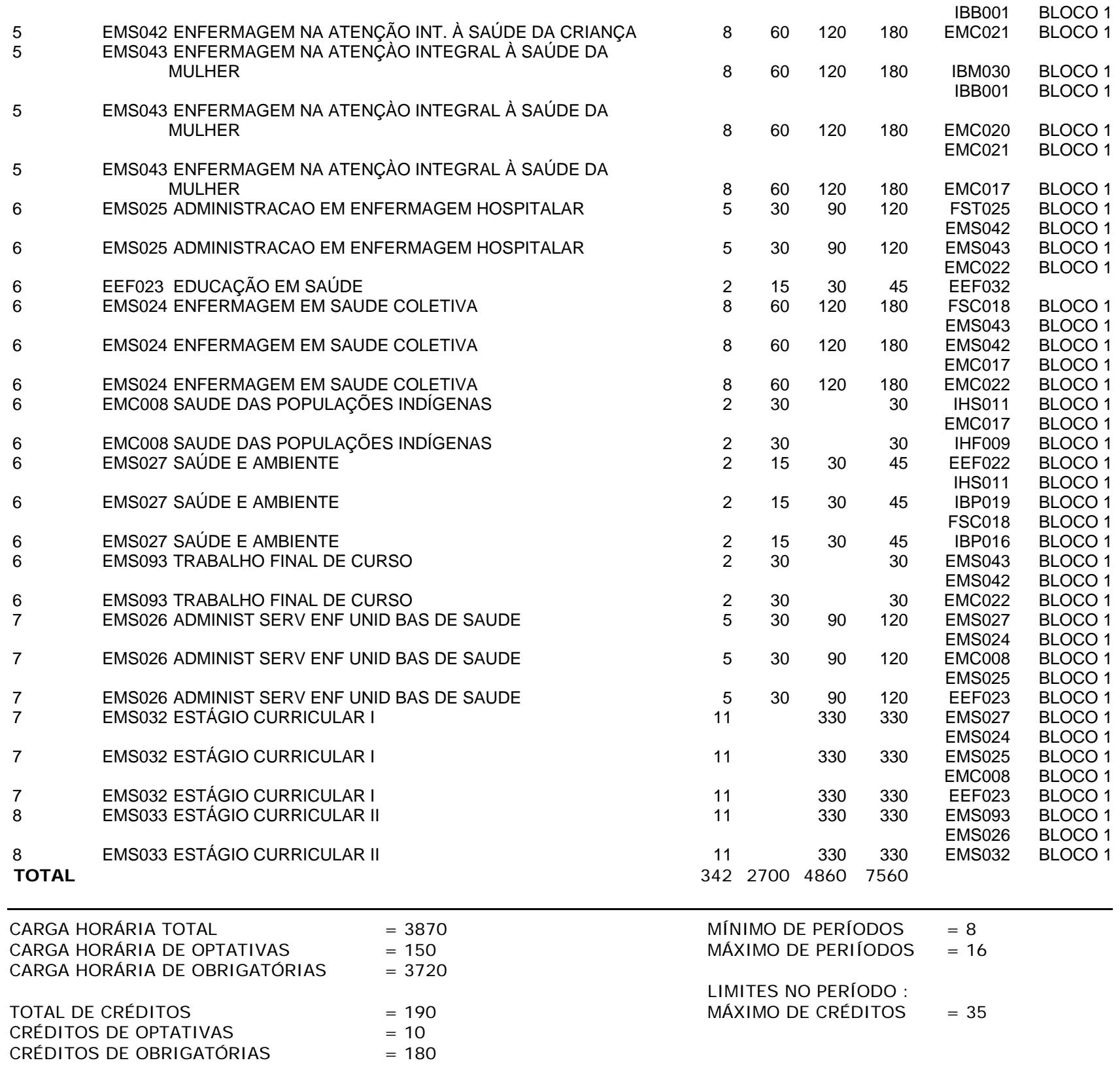


Anexo IV: Matriz Curricular do Curso de Medicina para a turma do último período cursado no primeiro semestre de 2007.

Curso: FS02 - Medicina

Grau do Curso: Médico
Turno: Diurno
Versão: 1985/1

Situação: Corrente

CARGA HORÁRIA

PERÍ OdO CÓD.

CRÉd. TEOR. PRAT. TOTAL PRÉ-REQUISITO

\begin{tabular}{|c|c|c|c|c|c|c|c|c|}
\hline \multicolumn{9}{|c|}{ OPTATIVAS } \\
\hline & IHE018 & ESPANHOL I & 5 & 75 & & 75 & & \\
\hline & IHE028 & ESPANHOL II & 5 & 75 & & 75 & IHE018 & \\
\hline & IHS113 & ESTUDO DE PROBLEMAS BRASILEIROS I & 1 & 15 & & 15 & & \\
\hline & IHS123 & ESTUDO DE PROBLEMAS BRASILEIROS II & 1 & 15 & & 15 & & \\
\hline & IHE022 & FRANCES II & 5 & 75 & & 75 & & \\
\hline & IHE037 & FRANCES INSTRUMENTAL & 5 & 75 & & 75 & & \\
\hline & FSG039 & FUNDAMENTOS DE ONCOLOGIA & 3 & 15 & 60 & 75 & $\begin{array}{l}\text { FSD016 } \\
\text { FSG038 }\end{array}$ & \\
\hline & FSC021 & HIGIENE SOCIAL & 2 & 30 & & 30 & & \\
\hline & FSG019 & HISTORIA DA MEDICINA & 5 & 75 & & 75 & & \\
\hline & FSC065 & HOMEOPATIA & 3 & 45 & & 45 & $\begin{array}{l}\text { FSD016 } \\
\text { FSD026 }\end{array}$ & \\
\hline & FSC065 & HOMEOPATIA & 3 & 45 & & 45 & FSD036 & \\
\hline & IHE030 & INGLES INSTRUMENTAL I & 5 & 75 & & 75 & & \\
\hline & IHP011 & PORTUGUES INSTRUMENTAL & 5 & 75 & & 75 & & \\
\hline & FSD030 & PSICANÁLISE NA CULTURA & 3 & 30 & 30 & 60 & & \\
\hline & FEF011 & PSICOLOGIA GERAL I & 4 & 60 & & 60 & & \\
\hline & FSD056 & PSICOPATOLOGIA & 3 & 30 & 30 & 60 & FSD029 & \\
\hline & APC001 & SALDO DE CRÉDITOS (Aprov. e Equivalencia ) & & & & & & \\
\hline & FSD017 & TÓPICOS ESPECIAIS EM MEDICINA & 4 & 60 & & 60 & & \\
\hline TOTAL & & & 62 & 870 & 120 & 990 & & \\
\hline \multicolumn{9}{|c|}{ OBRIGATÓRIAS } \\
\hline 1 & IBM088 & CITOLOGIA & 3 & 45 & & 45 & & \\
\hline 1 & IEE091 & COMPLEMENTOS DE MATEMATICA E ESTATISTICA & 4 & 60 & & 60 & & \\
\hline 1 & IEF002 & FISICA FUNDAMENTAL & 4 & 45 & 30 & 75 & & \\
\hline 1 & IBM111 & FUNDAMENTOS DE ANATOMIA & 6 & 90 & & 90 & & \\
\hline 1 & IBB001 & GENETICA BASICA & 3 & 45 & & 45 & & \\
\hline 2 & IBM032 & ANATOMIA II & 9 & 90 & 90 & 180 & IBM111 & \\
\hline 2 & IBF023 & FISIOLOGIA I & 6 & 60 & 60 & 120 & IBM088 & \\
\hline 2 & IBM056 & HISTOLOGIA & 6 & 60 & 60 & 120 & IBM088 & \\
\hline 2 & IEQ200 & QUIMICA BASICA & 7 & 90 & 30 & 120 & & \\
\hline 3 & IBF021 & BIOQUIMICA I & 8 & 105 & 30 & 135 & IEQ200 & \\
\hline 3 & IBM027 & EMBRIOLOGIA & 2 & 30 & & 30 & IBM056 & \\
\hline 3 & IBP031 & MICROBIOLOGIA E IMUNOLOGIA & 6 & 90 & & 90 & IBM056 & \\
\hline 3 & IBP032 & PARASITOLOGIA & 8 & 120 & & 120 & & \\
\hline \multirow[t]{2}{*}{4} & FSC018 & EPIDEMIOLOGIA I & 3 & 30 & 30 & 60 & IEE091 & BLOCO 1 \\
\hline & & & & & & & IBP031 & BLOCO 1 \\
\hline 4 & FSC018 & EPIDEMIOLOGIA I & 3 & 30 & 30 & 60 & IBP032 & BLOCO 1 \\
\hline 4 & IBF032 & FARMACOLOGIA I & 6 & 90 & & 90 & IBF023 & \\
\hline 4 & FSL041 & PATOLOGIA I & 8 & 120 & & 120 & IBP031 & \\
\hline 5 & FSG018 & FUNDAMENTOS DE CIRURGIA E ANESTESIA & 5 & 30 & 90 & 120 & IBM032 & \\
\hline 5 & FSD016 & INICIACAO AO EXAME CLINICO & 9 & 90 & 90 & 180 & FSL041 & \\
\hline 5 & FSL061 & PATOLOGIA II & 3 & 30 & 30 & 60 & FSL041 & \\
\hline 5 & FSD029 & PSICOLOGIA MEDICA & 4 & 30 & 60 & 90 & & \\
\hline 6 & FSG038 & CLINICA CIRURGICA I & 7 & 60 & 90 & 150 & FSG018 & \\
\hline 6 & FSC016 & DOENCAS INFECCIOSAS E PARASITARIAS & 6 & 45 & 90 & 135 & FSD016 & \\
\hline 6 & FSL019 & MEDICINA LEGAL E DEONTOLOGIA & 3 & 30 & 30 & 60 & IBF023 & \\
\hline \multirow[t]{2}{*}{6} & FSL071 & PATOLOGIA III & 3 & 30 & 30 & 60 & FSL041 & BLOCO 1 \\
\hline & & & & & & & FSL061 & BLOCO 1 \\
\hline 7 & FSD026 & CLINICA MEDICA I & 8 & 60 & 120 & 180 & FSD016 & \\
\hline 7 & FSD046 & CLINICA PSIQUIATRICA & 3 & 30 & 30 & 60 & FSD029 & \\
\hline 7 & FSG027 & OTORRINOLARINGOLOGIA & 3 & 15 & 60 & 75 & FSD016 & \\
\hline 7 & FSG037 & UROLOGIA & 3 & 15 & 60 & 75 & FSG018 & \\
\hline 8 & FSC017 & CLINICA DERMATOLOGICA & 6 & 60 & 60 & 120 & FSD016 & \\
\hline 8 & FSD036 & CLINICA MEDICA II & 8 & 60 & 120 & 180 & FSD016 & \\
\hline 8 & FSG028 & TRAUMATO-ORTOPEDIA & 6 & 60 & 60 & 120 & FSG018 & \\
\hline 9 & FSG048 & CLINICA CIRURGICA II & 6 & 60 & 60 & 120 & FSG038 & \\
\hline 9 & FSI023 & CLINICA PEDIATRICA E PUERICULTURA & 8 & 60 & 120 & 180 & FSD016 & \\
\hline 9 & FSG058 & NEUROLOGIA E NEUROCIRURGIA & 4 & 30 & 60 & 90 & FSG038 & \\
\hline 9 & FSG056 & OFTALMOLOGIA & 3 & 30 & 30 & 60 & FSD016 & \\
\hline 10 & FSI042 & CLINICA GINECOLOGICA & 7 & 60 & 90 & 150 & FSG038 & \\
\hline 10 & FSIO24 & CLINICA OBSTETRICA & 7 & 30 & 150 & 180 & FSG038 & \\
\hline \multirow[t]{2}{*}{10} & FSC019 & EPIDEMIOLOGIA II & 4 & 60 & & 60 & FSC018 & BLOCO 1 \\
\hline & & & & & & & FSD026 & BLOCO 1 \\
\hline 10 & FSC014 & SAUDE COLETIVA & 4 & 30 & 60 & 90 & IBP031 & BLOCO 1 \\
\hline
\end{tabular}




$\begin{array}{lll}11 & \text { FSYO02 } & \text { ESTAGIO EM CIRURGIA } \\ 11 & \text { FSYO01 } & \text { ESTAGIO EM CLINICA MEDICA } \\ 11 & \text { FSY005 } & \text { ESTAGIO EM MEDICINA PREVENTIVA } \\ 11 & \text { FSY003 } & \text { ESTAGIO EM PEDIATRIA } \\ 11 & \text { FSY004 } & \text { ESTAGIO EM TOCO-GINECOLOGIA } \\ \text { TOTAL } & & \end{array}$

$\begin{array}{rrrr}20 & & 600 & 600 \\ 20 & & 600 & 600 \\ 20 & & 600 & 600 \\ 20 & & 600 & 600 \\ 20 & & 600 & 600 \\ 312 & 2205 & 4950 & 7155\end{array}$

IBP032 BLOCO 1

CARGA HORÁRI A TOTAL

CARGA HORÁRI A DE OPTATIVAS

CARGA HORÁRIA DE OBRIGATÓRIAS

TOTAL DE CRÉDITOS

CRÉDITOS DE OPTATIVAS

CRÉDITOS DE OBRIGATÓRIAS

$=$
$=$
$=$
$=325$
$=$
$=$

MÍNIMO DE PERÍODOS

MÁXIMO DE PERIIIODOS

$=10$

$=18$
LIMITES NO PERÍODO : 
Anexo V: Matriz Curricular do Curso de Odontologia para a turma do último período cursado no primeiro semestre de 2007.

Curso: FS03 - Odontologia

Grau do Curso: Cirurgião Dentista Turno: Diurno

Versão: 2001

Situação: Corrente

CARGA HORÁRI A

PERÍODO CÓD.

NOME DA DISCI PLI NA

CRÉd. TEOR. PRAT. TOTAL PRÉ-REQUISITO

\section{OPTATIVAS}

FSP061 ETICA PROFISSIONAL EM ODONTOLOGIA

FSP043 ODONTOLOGIA SOCIAL II

APC001 SALDO DE CRÉDITOS (Aprov. e Equivalencia)

FSP002 TOPICOS ESPECIAIS EM ODONTOLOGIA

TOTAL

\begin{tabular}{|c|c|c|}
\hline 1 & IBF022 & BIOQUIMICA \\
\hline 1 & IBM007 & CITOLOGIA \\
\hline 1 & IBM101 & FUNDAMENTOS DE ANATOMIA \\
\hline 1 & IBB001 & GENETICA BASICA \\
\hline & FSP003 & INTRODUÇAO A ODONTOLOGIA \\
\hline 1 & FSP005 & METODOLOGIA DA PESQUISA DA SAUDE \\
\hline & FSP004 & ODONTOLOGIA EM SAUDE COLETIVA \\
\hline 2 & IBM102 & ANATOMIA DE CABEÇA E PESCOÇO \\
\hline 2 & IBF023 & FISIOLOGIA I \\
\hline 2 & IBF023 & FISIOLOGIA I \\
\hline 2 & IBM018 & HISTOLOGIA \\
\hline 2 & IBP005 & MICOLOGIA \\
\hline 2 & IBP019 & MICROBIOLOGIA \\
\hline 2 & IBP004 & PARASITOLOGIA \\
\hline 3 & FSR001 & ANATOMIA E ESCULTURA DENTAL \\
\hline 3 & IEE006 & BIOESTATISTICA \\
\hline 3 & IBF007 & FARMACOLOGIA I \\
\hline 3 & IBM066 & HISTOLOGIA ESPECIAL \\
\hline 3 & IBP015 & IMUNOLOGIA BASICA \\
\hline 3 & IEC001 & INFORMÁTICA APLICADA À ODONTOLOGIA \\
\hline 3 & FSL082 & PATOLOGIA GERAL \\
\hline 4 & FSE028 & DIAGNOSTICO BUCAL \\
\hline 4 & FSE028 & DIAGNOSTICO BUCAL \\
\hline 4 & FSR036 & MATERIAIS DENTÁRIOS I \\
\hline 4 & FSR002 & OCLUSÃO \\
\hline 4 & FSL083 & PATOLOGIA BUCAL \\
\hline 4 & FEP002 & PSICOLOGIA APLICADA A ODONTOLOGIA \\
\hline 4 & FSE001 & RADIOLOGIA \\
\hline 4 & FSE001 & RADIOLOGIA \\
\hline 4 & FSE003 & TERAPEUTICA MEDICAMENTOSA EM ODONTOLOGIA \\
\hline 4 & FSE003 & TERAPEUTICA MEDICAMENTOSA EM ODONTOLOGIA \\
\hline & FSE004 & CARIOLOGIA \\
\hline 5 & FSE004 & CARIOLOGIA \\
\hline 5 & FSE030 & CIRURGIA BUCAL \\
\hline 5 & FSE030 & CIRURGIA BUCAL \\
\hline 5 & FSR030 & DENTISTICA I \\
\hline 5 & FSR030 & DENTISTICA I \\
\hline & FSR046 & MATERIAIS DENTÁRIOS II \\
\hline & FSE010 & PERIODONTIA I \\
\hline
\end{tabular}

\begin{tabular}{|c|c|c|c|c|c|}
\hline 3 & 45 & & 45 & FSP003 & BLOCO 1 \\
\hline & & & & FSP005 & BLOCO 1 \\
\hline 3 & 15 & 60 & 75 & FSE030 & BLOCO 1 \\
\hline & & & & FSP006 & BLOCO 1 \\
\hline 4 & 60 & & 60 & FSP007 & BLOCO 1 \\
\hline & & & & FSR070 & BLOCO 1 \\
\hline 10 & 120 & 60 & 180 & & \\
\hline 5 & 60 & 30 & 90 & & \\
\hline 3 & 15 & 60 & 75 & & \\
\hline 4 & 30 & 60 & 90 & & \\
\hline 3 & 45 & & 45 & & \\
\hline 2 & 30 & & 30 & & \\
\hline 3 & 45 & & 45 & & \\
\hline 3 & 45 & & 45 & & \\
\hline 3 & 15 & 60 & 75 & IBM101 & \\
\hline 6 & 60 & 60 & 120 & IBM007 & BLOCO 1 \\
\hline & & & & IBF022 & BLOCO 1 \\
\hline 6 & 60 & 60 & 120 & IBM101 & BLOCO 1 \\
\hline 5 & 60 & 30 & 90 & IBM007 & \\
\hline 2 & 15 & 30 & 45 & IBB001 & BLOCO 1 \\
\hline & & & & IBM007 & BLOCO 1 \\
\hline 3 & 30 & 30 & 60 & IBB001 & \\
\hline & & & & IBM007 & \\
\hline 2 & 15 & 30 & 45 & IBB001 & BLOCO 1 \\
\hline & & & & IBM007 & BLOCO 1 \\
\hline 3 & 15 & 60 & 75 & IBM102 & \\
\hline 4 & 60 & & 60 & FSP005 & \\
\hline 5 & 75 & & 75 & IBF023 & \\
\hline 4 & 30 & 60 & 90 & IBM018 & \\
\hline 3 & 45 & & 45 & IBM018 & BLOCO 1 \\
\hline & & & & IBP019 & BLOCO 1 \\
\hline 2 & & 60 & 60 & IBM018 & \\
\hline 4 & 45 & 30 & 75 & IBM018 & BLOCO 1 \\
\hline & & & & IBP019 & BLOCO 1 \\
\hline 4 & 15 & 90 & 105 & IBF007 & BLOCO 1 \\
\hline & & & & FSR001 & BLOCO 1 \\
\hline 4 & 15 & 90 & 105 & FSL082 & BLOCO 1 \\
\hline 3 & 30 & 30 & 60 & IBF023 & BLOCO 1 \\
\hline & & & & FSR001 & BLOCO 1 \\
\hline 3 & 30 & 30 & 60 & FSR001 & BLOCO 1 \\
\hline & & & & FSL082 & BLOCO 1 \\
\hline 4 & 45 & 30 & 75 & FSL082 & \\
\hline 3 & 45 & & 45 & FSP003 & BLOCO 1 \\
\hline & & & & FSP005 & BLOCO 1 \\
\hline 4 & 30 & 60 & 90 & IBM066 & BLOCO 1 \\
\hline & & & & FSR001 & BLOCO 1 \\
\hline 4 & 30 & 60 & 90 & FSL082 & BLOCO 1 \\
\hline 3 & 45 & & 45 & IBP015 & BLOCO 1 \\
\hline & & & & IBF007 & BLOCO 1 \\
\hline 3 & 45 & & 45 & FSL082 & BLOCO 1 \\
\hline 3 & 15 & 60 & 75 & FSE001 & BLOCO 1 \\
\hline & & & & FSE028 & BLOCO 1 \\
\hline 3 & 15 & 60 & 75 & FSL083 & BLOCO 1 \\
\hline 6 & 30 & 120 & 150 & FSE001 & BLOCO 1 \\
\hline & & & & FSL083 & BLOCO 1 \\
\hline 6 & 30 & 120 & 150 & FSE028 & BLOCO 1 \\
\hline & & & & FSE003 & BLOCO 1 \\
\hline 4 & 30 & 60 & 90 & FSE028 & BLOCO 1 \\
\hline & & & & FSR036 & BLOCO 1 \\
\hline 4 & 30 & 60 & 90 & FSR002 & BLOCO 1 \\
\hline 3 & 15 & 60 & 75 & FSR036 & BLOCO 1 \\
\hline 4 & 30 & 60 & 90 & FSE001 & BLOCO 1 \\
\hline & & & & FSL083 & BLOCO 1 \\
\hline
\end{tabular}


FSE010 PERIODONTIA I

FSR032 DENTÍSTICA II

FSR040 ENDODONTIA I

FSP006 ODONTOLOGIA SOCIAL

FSP006 ODONTOLOGIA SOCIAL

FSP006 ODONTOLOGIA SOCIAL FSE020 PERIODONTIA II

FSR080 PRÓTESE I

FSR060 CLINICA INTEGRADA I

FSR060 CLINICA INTEGRADA I

FSR033 DENTISTICA III

FSR050 ENDODONTIA II

FSP022 ODONTOPEDIATRIA I

FSP022 ODONTOPEDIATRIA I

FSP001 ORTODONTIA

FSP001 ORTODONTIA

FSR090 PROTESE II - FIXA

FSE035 CIRURGIA E T. BUCO-MAXILO-FACIAL

FSR070 CLINICA INTEGRADA II

FSR070 CLINICA INTEGRADA II

FSP032 ODONTOPEDIATRIA II

FSP007 ORIENTAÇÃO PROFISSIONAL

FSR100 PRÓTESE III - REMOVÍVEL

FSR100 PRÓTESE III - REMOVÍVEL

FSP012 ESTÁGIO CURRICULAR I

FSP012 ESTÁGIO CURRICULAR I

FSP012 ESTÁGIO CURRICULAR I

FSP012 ESTÁGIO CURRICULAR I

FSP012 ESTÁGIO CURRICULAR I

FSP012 ESTÁGIO CURRICULAR I

FSP012 ESTÁGIO CURRICULAR I

FSP012 ESTÁGIO CURRICULAR I

FSP012 ESTÁGIO CURRICULAR I

FSP012 ESTÁGIO CURRICULAR I

FSP012 ESTÁGIO CURRICULAR I

FSP012 ESTÁGIO CURRICULAR I

FSP012 ESTÁGIO CURRICULAR I

FSP012 ESTÁGIO CURRICULAR I

FSP012 ESTÁGIO CURRICULAR I

FSP012 ESTÁGIO CURRICULAR I

FSP012 ESTÁGIO CURRICULAR I

FSP012 ESTÁGIO CURRICULAR I

FSP012 ESTÁGIO CURRICULAR I

FSP012 ESTÁGIO CURRICULAR I

(4)

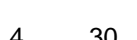

$4 \quad 30$

$4 \quad 15$

$4 \quad 30$

$3 \quad 15$

$3 \quad 15$

$3 \quad 15$

$4 \quad 30$

$4 \quad 15$

4

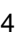

4

$5 \quad 15$

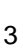

3

3
3

4

4
3
3

3

3

15

15

15

15

15

15

15

15

15

15

15

15

15

15

15

15

15

15

15

15

15

\begin{tabular}{|c|c|c|c|}
\hline 60 & 90 & $\begin{array}{l}\text { FSE028 } \\
\text { FSE003 }\end{array}$ & $\begin{array}{l}\text { BLOCO } 1 \\
\text { BLOCO } 1\end{array}$ \\
\hline \multirow[t]{2}{*}{90} & 105 & FSE030 & BLOCO 1 \\
\hline & & FSR030 & BLOCO 1 \\
\hline \multirow[t]{2}{*}{60} & 90 & FSE030 & BLOCO 1 \\
\hline & & FSR030 & BLOCO 1 \\
\hline \multirow[t]{2}{*}{60} & 75 & FSP004 & BLOCO 1 \\
\hline & & FSE004 & BLOCO 1 \\
\hline \multirow[t]{2}{*}{60} & 75 & FSE010 & BLOCO 1 \\
\hline & & FSE030 & BLOCO \\
\hline 60 & 75 & FSR030 & BLOCO 1 \\
\hline \multirow[t]{2}{*}{60} & 90 & FSE030 & BLOCO 1 \\
\hline & & FSE010 & BLOCO 1 \\
\hline \multirow[t]{2}{*}{90} & 105 & FSE010 & \\
\hline & & FSR046 & \\
\hline \multirow[t]{2}{*}{120} & 120 & FSR032 & BLOCO 1 \\
\hline & & FSR040 & BLOCO 1 \\
\hline \multirow[t]{2}{*}{120} & 120 & FSE020 & BLOCO 1 \\
\hline & & FSR080 & BLOCO 1 \\
\hline \multirow[t]{2}{*}{60} & 90 & FSR032 & BLOCO 1 \\
\hline & & FSR040 & BLOCO \\
\hline 120 & 135 & FSR040 & \\
\hline \multirow[t]{2}{*}{60} & 90 & FEP002 & BLOCO 1 \\
\hline & & FSR032 & BLOCO \\
\hline \multirow[t]{2}{*}{60} & 90 & FSR040 & BLOCO 1 \\
\hline & & FSE020 & BLOCO \\
\hline \multirow[t]{2}{*}{60} & 75 & FSR002 & BLOCO \\
\hline & & FSE020 & BLOCO \\
\hline 60 & 75 & FSR046 & BLOCO 1 \\
\hline \multirow[t]{2}{*}{60} & 75 & FSR032 & BLOCO 1 \\
\hline & & FSR080 & BLOCO \\
\hline \multirow[t]{2}{*}{60} & 105 & FSP022 & BLOCO \\
\hline & & FSR050 & BLOCO \\
\hline \multirow[t]{2}{*}{120} & 120 & FSR090 & BLOCO \\
\hline & & FSR050 & BLOCO \\
\hline 120 & 120 & FSR060 & BLOCO \\
\hline \multirow[t]{3}{*}{90} & 90 & FSP022 & \\
\hline & 45 & FSP006 & \\
\hline & & FSP022 & \\
\hline \multirow[t]{2}{*}{60} & 75 & FSR090 & BLOCO \\
\hline & & FSR060 & BLOCO \\
\hline 60 & 75 & FSR050 & BLOCO \\
\hline
\end{tabular}




\begin{tabular}{|c|c|c|c|c|c|c|}
\hline \multirow[b]{2}{*}{9} & \multirow[b]{2}{*}{ FSP012 ESTÁGIO CURRICULAR I } & \multirow[b]{2}{*}{15} & \multirow{2}{*}{\multicolumn{2}{|c|}{450}} & \multirow[b]{2}{*}{450} & \multirow{2}{*}{$\begin{array}{l}\text { FSR090 } \\
\text { FSP001 } \\
\text { FSR060 }\end{array}$} \\
\hline & & & & & & \\
\hline 9 & FSP012 ESTÁGIO CURRICULAR I & 15 & & 450 & 450 & $\begin{array}{l}\text { FSR050 } \\
\text { FSP007 }\end{array}$ \\
\hline 9 & FSP012 ESTÁGIO CURRICULAR I & 15 & & 450 & 450 & $\begin{array}{l}\text { FSR070 } \\
\text { FSE035 }\end{array}$ \\
\hline 9 & FSP012 ESTÁGIO CURRICULAR I & 15 & & 450 & 450 & FSR100 \\
\hline 10 & FSP023 ESTÁGIO CURRICULAR II & 15 & & 450 & 450 & FSP012 \\
\hline & & 606 & 1755 & 14670 & 16425 & \\
\hline
\end{tabular}

\begin{tabular}{llll}
\hline CARGA HORÁRIA TOTAL & $=4830$ & MÍNIMO DE PERÍODOS & $=10$ \\
CARGA HORÁRIA DE OPTATIVAS & $=150$ & MÁXIMO DE PERIÍODOS & $=18$ \\
CARGA HORÁRIA DE OBRIGATÓRIAS & $=4680$ & & \\
& & LIMITES NO PERÍODO : & \\
TOTAL DE CRÉDITOS & $=213$ & MÁXIMO DE CRÉDITOS & $=25$ \\
CRÉDITOS DE OPTATIVAS & $=10$ & & \\
CRÉDITOS DE OBRIGATÓRIAS & $=203$ &
\end{tabular}

